\title{
Caracterização molecular e bioquímica da prolina desidrogenase de Trypanosoma cruzi, um possível alvo terapêutico
}

Tese apresentada ao Programa de Pós-graduação em Biologia da Relação Patógeno-Hospedeiro do Instituto de Ciências Biomédicas da Universidade de São Paulo, para obtenção do Título de Doutor em Ciências.

São Paulo

2010 


\section{LISVANE PAES VIEIRA}

\section{Caracterização molecular e bioquímica da prolina desidrogenase de Trypanosoma cruzi, um possível alvo terapêutico}

Tese apresentada ao Programa de Pós-graduação em Biologia da Relação Patógeno-Hospedeiro do Instituto de Ciências Biomédicas da Universidade de São Paulo, para obtenção do Título de Doutor em Ciências.

Área de Concentração: Biologia da Relação Patógeno-Hospedeiro

Orientador: Ariel Mariano Silber

São Paulo 
DADOS DE CATALOGAÇÃO NA PUBLICAÇÃO (CIP)

Serviço de Biblioteca e Informação Biomédica do

Instituto de Ciências Biomédicas da Universidade de São Paulo

(C) reprodução total

Vieira, Lisvane Paes.

Caracterização molecular e bioquímica da prolina desidrogenase de Trypanosoma cruzi, um possível alvo terapêutico / Lisvane Paes Vieira. -- São Paulo, 2010.

Orientador: Ariel Mariano Silber.

Tese (Doutorado) - Universidade de São Paulo. Instituto de Ciências Biomédicas. Departamento de Parasitologia. Área de concentração:

Biologia da Relação Patógeno-Hospedeiro. Linha de pesquisa:

Bioquímica e biologia molecular de tripanossomatídeos

Versão do título para o inglês: Molecular and biochemical characterization of the proline dehydrogenase of Trypanosoma. cruzi, a possible therapeutical target.

Descritores: 1. Trypanosoma cruzi 2. Via prolina-glutamato 3. Prolina desidrogenase 4. Tripanosomatidae 5. Enzimas 6. Glutamatos I. Silber, Ariel Mariano II. Universidade de São Paulo. Instituto de Ciências Biomédicas. Programa de Pós-Graduação em Parasitologia. III. Título. 


\title{
UNIVERSIDADE DE SÃO PAULO \\ INSTITUTO DE CIÊNCIAS BIOMÉDICAS
}

\begin{abstract}
Candidato(a):
Lisvane Paes Vieira.

Título da Tese:

Caracterização molecular e bioquímica da prolina

alvo desidrogenase de Trypanosoma cruzi, um possível terapêutico.
\end{abstract}

Orientador(a):

Ariel Mariano Silber. 
Trabalho realizado com auxílios financeiros concedido pelo Conselho Nacional de Desenvolvimento Científico e Tecnológico (CNPq), Instituto Nacional de Biotecnologia Estrutural e Química Medicinal em Doenças Infecciosas (INBEQMeDI) e Fundação de Amparo à Pesquisa do Estado de São Paulo (FAPESP). 


\section{Certificado}

Certificamos que o protocolo registrado sob $\mathrm{n}^{\circ} \mathbf{1 2 3}$ nas fls. 37 do livro 2 para uso de animais em experimentação, sob a responsabilidade de Ariel M. Silber, Coordenador(a) da Linha de pesquisa "Caracterização molecular e bioquimica da Prolina Oxidase de trypanosoma cruzi, um possivel alvo terapêutico" do qual participou(aram) o(s) alunos Lisvane Silva Paes, Robert L.Galvez Rojas, está de acordo com os Princípios Éticos de Experimentação Animal adotado pelo Colêgio Brasileiro de Experimentação Animal (COBEA) e foi aprovado pela COMISSÃO DE ÉTICA EM EXPERIMENTAÇÃO ANIMAL (CEEA) em 17.10.2006.

São Paulo, 18 de outubro de 2006.

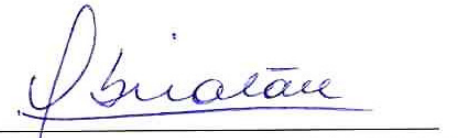

Prof. Dr. UBIRATAN FABRES MACHADO Coordenador da CEEA - ICB/USP

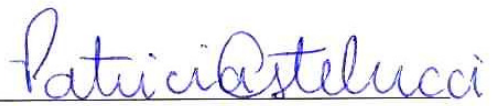

Profa. Dra. PATRÍCIA CASTELUCCI Secretária da CEEA - ICB/USP 
Ao meu marido André pelo amor e apoio incondicional durante todos esses anos. 


\section{AGRADECIMENTOS}

Ao Prof. Ariel Mariano Silber pela orientação, confiança, sobretudo pelo apoio, paciência e amizade ao longo desses anos.

À Beth pela amizade, conselhos e todo suporte técnico.

Aos amigos do laboratório, Anahí, Denise, Inga, Jahangir, Jean Douglas, Josué, Julia, Sandra Carla e Rafael pelo companheirismo e alegria.

Aos amigos Flavinha e o Brian pela grande ajuda durante os experimentos, pelo companherismo e carinho.

À Prof ${ }^{a}$ Lucile Maria Floeter e aos demais integrantes de seu laboratório: Ricardo, Marcos e Maria Fernanda, pela amizade e suporte científico nos primeiros anos deste trabalho.

À Prof ${ }^{a}$ Ana Paula Ulian e a Andressa pela colaboração e discussão de alguns resultados.

À Prof ${ }^{a}$ Fernanda Gadelha e aos seus alunos, Simone e Eduardo pelo apoio e discussões que muito contribuíram para este trabalho.

À Prof ${ }^{a}$ Maria Carolina Elias e aos seus alunos, Patrícia, Simone e Ricardo pela parceria, discussões de trabalhos e principalmente pela amizade.

À Prof ${ }^{a}$ Alicia Kowaltowski e ao Erick pela colaboração e discussões de alguns resultados.

Aos professores, funcionários e colegas do departamento de Parasitologia-ICB (USP) pelo apoio e convivência.

À FAPESP pela bolsa e suporte para essa pesquisa e à USP.

À minha família e amigos pelo carinho e apoio durante todos esses anos. 
“

“...Sonhe com aquilo que você quer ser,

porque você possui apenas uma vida

e nela só se tem uma chance

de fazer aquilo que quer.

Tenha felicidade bastante para fazê-la doce.

Dificuldades para fazê-la forte.

Tristeza para fazê-la humana.

E esperança suficiente para fazê-la feliz.

As pessoas mais felizes não tem as melhores coisas.

Elas sabem fazer o melhor das oportunidades

que aparecem em seus caminhos.

A felicidade aparece para aqueles que choram.

Para aqueles que se machucam

Para aqueles que buscam e tentam sempre.

E para aqueles que reconhecem

a importância das pessoas que passaram por suas vidas..."

Clarice Lispector 


\section{RESUMO}

PAES, L. V. Caracterização molecular e bioquímica da prolina desidrogenase de Trypanosoma cruzi, um possível alvo terapêutico. Tese (Doutorado em Parasitologia)Instituto de Ciências Biomédicas,Universidade de São Paulo, São Paulo, 2010.

Os nossos resultados demonstraram a atividade enzimática prolina desidrogenase (PRODH) do produto do gene anotado como codificante de uma prolina oxidase na base dados do genoma de Trypanosoma cruzi. A atividade da proteína codificada por esse gene foi avaliada inicialmente por complementação de uma linhagem de Saccharomyces cerevisiae deficiente na expressão funcional da PRODH endógena, e posteriormente mediante a obtenção da enzima recombinante ativa expressa em um sistema bacteriano. Nos estudos feitos tanto com leveduras complementadas com o gene PRODH, quanto com as formas epimastigotas de $T$. cruzi, observamos que nesses organismos há uma correlação positiva entre o nível intracelular de prolina livre e a resistência ao estresse oxidativo. Através dos ensaios de RT-PCR quantitativo observamos que o RNAm do gene da PRODH é regulado ao longo do ciclo de vida do T. cruzi, com maior nível de expressão no estágio epimastigota intracelular, perfil apresentado também em experimentos de Western Blotting, o que é concordante com o papel fundamental desse aminoácido na diferenciação dessa forma para as forma tripomastigota. Nos diferentes ensaios de localização subcelular observou-se que a proteína PRODH está presente na mitocôndria. A sequiência da PRODH apresenta um sítio $E F$-hand de ligação a $\mathrm{Ca}^{2+}$. Mostramos experimentalmente a funcionalidade desse sítio e a sua função na regulação da atividade por $\mathrm{Ca}^{2+}$. Em ensaios de respiração mitocondrial, utilizando prolina como substrato, foi mostrado que a prolina fornece elétrons à cadeia respiratória através da $\mathrm{PRODH}$, transferindo elétrons e gerando $\mathrm{FADH}_{2}$ no mesmo nível e com a mesma eficiência que o complexo II (succinato desidrogenase). O análogo de prolina T4C, inibidor do transporte de prolina, causa uma diminuição do conteúdo de prolina livre intracelular, o que foi relacionado com uma diminuição significativa da sobrevivência do parasito em combinação com o estresse nutricional e oxidativo, mostrando a participação do metabolismo de prolina na resistência a esses estresses. Todos esses dados sugerem ademais que o transportador de prolina do parasita pode ser um alvo para drogas terapêuticas de interesse quando combinada com outras drogas que agem via geração de espécies reativas de oxigênio.

Palavras-chave: Trypanosoma cruzi.Via prolina-glutamato. Prolina desidrogenase. 


\begin{abstract}
PAES, L.V. Molecular and Biochemical Characterization of the proline dehydrogenase of $\boldsymbol{T}$. cruzi, a possible therapeutical target. $\mathrm{PhD}$ Thesis (Parasitology). Instituto de Ciências Biomédicas, Universidade de São Paulo, São Paulo, 2010.
\end{abstract}

In the present work, we demonstrated the proline dehydrogenase enzymatic activity (PRODH) for the protein encoded by a gene annotated as a proline oxidase in the $T$. cruzi genome data base. This activity was shown firstly through complementation of a Saccharomyces cerevisiae lineage lacking its endogenous PRODH gene. The PRODH gene was also expressed in a bacterial system and the active recombinant protein was obtained. Experiments performed with both, complemented yeasts and $T$. cruzi epimastigotes, showed a correlation between the intracellular free proline levels and the oxidative stress resistance. Quantitative RT-PCR assay revealed that the PRODH gene is differentially expressed during $T$. cruzi life cycle, being the highest expression level shown by the intracellular epimastigote form. This result was confirmed by Western blotting. Both results are in accordance with the fact that proline is essential for the differentiation of the intracellular epimastigote into trypomastigote. Subcellular localization assays showed that PRODH is present in the mitochondria. In silico analyses of the PRODH peptidic sequence indicated the presence of an EF-hand domain, wich is, usually, involved in $\mathrm{Ca}^{2+}$ binding. In fact, our results confirm not only the ability this domain of binding $\mathrm{Ca}^{2+}$ but also its function in the activity regulation. Mitochondrial respiration assays using proline as substrate showed that PRODH transfers electrons and generates $\mathrm{FADH}_{2}$, with an eficiency comparable to that of the complex II (Succinate dehydrogenase). Experiments using the $\mathrm{T} 4 \mathrm{C}$, an analogue of proline that inhibits the proline uptake, caused the depletion of the intracellular free proline, which was followed by the significantly decrement of the cellular viability of the parasites under nutritional and oxidative stresses. Taken together, these data suggest that proline transporters are promising drug targets when combined with other drugs that act by generating reactive oxygen species.

Keywords: Trypanosoma cruzi. Proline-glutamate pathway. Proline dehydrogenase. 


\section{LISTA DE FIGURAS}

Figura 1. Representação esquemática do ciclo de vida do Trypanosoma cruzi. 23

Figura 2. Representação esquemática do metabolismo de fontes de carbono e aminoácidos em T. cruzi.

Figura 3. Quadro com a descrição das enzimas presentes na representação esquemática do metabolismo de fontes de carbono e aminoácidos em T. cruzi. 34

Figura 4. Representação esquemática do metabolismo de L-prolina 43

Figura 5. Quadro das células de bactérias utilizadas no trabalho 47

Figura 6. Quadro das leveduras utilizadas no trabalho

47

Figura 7. Quadro dos vetores e gene utilizados no trabalho 48

Figura 8. Quadro dos oligonucleotídeos utilizados no trabalho $\quad 48$

Figura 9. Qualidade dos RNAs ribossomais obtidos a partir das diferentes fases do ciclo de vida de $T$. cruzi, células de mamífero e S. cerevisiae.

Figura 10. Representação dos índices de hidrofobicidade, antigenicidade e probabilidade de superfície para a proteína PRODH de T. cruzi de acordo com o programa DNAStar versão 5.00.

Figura 11. Representação da estrutura química de L-prolina e seus análogos. $\quad 68$

Figura 12. Amplificação da fase aberta de leitura (ORF) do gene PRODH de T. cruzi e clonagem em vetor pGEM-T.

Figura 13: Alinhamento das seqüências de aminoácidos da PRODH de T. cruzi e os seus correspondentes ortólogos em T. brucei, L. major, H. sapiens e $S$. cerevisiae.

Figura 14. Representação esquemática dos domínios protéicos presentes na PRODH de T. cruzi.

Figura 15. Análise do domínio EF-hand presente na PRODH de T. cruzi.

Figura 16. Região de sinalização mitocondrial da proteína PRODH de T. cruzi predita através do programa Mitoprot II.

Figura 17. Clonagem do gene PRODH de T. cruzi em vetor pYES.

Figura 18. Complementação funcional de $S$. cerevisiae com o gene de PRODH de T. cruzi. 
Figura 19. Perfil de transcrição do gene de PRODH de T.cruzi por RT-PCR semi-quantitativo e análise da proteína PRODH por Western Blotting.

Figura 20. Ensaio de atividade da enzima PRODH.

Figura 21. Perfís transcricional e traducional do gene PRODH ao longo do ciclo de vida de $T$. cruzi.

Figura 22. Ensaio de microscopia de fluorêscencia de todos os estágios do ciclo de vida do $T$. cruzi.

Figura 23. Localização subcelular da PRODH de T. cruzi por extração com digitonina.

Figura 24. Análise da expressão da PRODH.

Figura 25. Efeito da concentração de substrato na atividade da PRODH recombinante.

Figura 26. Atividade da PRODH recombinante em função de diferentes cofatores e substratos.

Figura 27. Avaliação do produto formado na reação de atividade da PRODH por espectrofotometria de varredura.

Figura 28. Detecção fluorescente, visualizada por luz UV, do cálcio ligado à proteína PRODH utilizando o reagente QUIN-2.

Figura 29. Atividade da PRODH recombinante na presença de quelantes de íons divalentes.

Figura 30. Viabilidade celular das leveduras em estudo submetidas a estresse oxidativo.

Figura 31. Valores da razão das taxas de GSSG/GSH e a concentração de prolina intracelular livre das leveduras em estudo submetidas a estresse oxidativo.

Figura 32. Viabilidade celular e concentrações intracelulares de prolina interna livre de formas epimastigotas de T. cruzi submetidas a estresse oxidativo.

Figura 33. Atividade da enzima PRODH e PR em extrato total de epimastigotas de $T$. cruzi.

Figura 34. Transporte de L-prolina na presença de T4C $(0,5 \mathrm{mM})$ em epimastigotas de T. cruzi. 
Figura 35. Viabilidade celular e concentrações intracelulares de prolina interna livre de epimastigotas de $T$. cruzi submetidos a estresse oxidativo.

Figura 36. Densidade celular de epimastigotas de $T$. cruzi submetidos a estresse oxidativo.

Figura 37. Atividade da enzima Citrato Sintase.

Figura 38. Atividade da PRODH em fração mitocondrial purificada de epimastigotas de $T$. cruzi.

Figura 39. Taxas do consumo de oxigênio na presença dos substratos succinato e prolina (a nível de complexo II).

Figura 40. Concentração de prolina intracelular livre.

Figura 41. Variações relativas das atividades dos transportadores de glicose e prolina e concentrações de prolina intracelular livre durante o ciclo de vida do T. cruzi.

Figura 42. Participação da prolina em outras vias metabólicas. 


\section{LISTA DE ABREVIATURAS}

\begin{tabular}{|c|c|}
\hline Acetil-CoA & Acetil coenzima A \\
\hline ADP & Adenosina difosfato \\
\hline AEBSF & Cloridrato de fluoreto 4-(2-amino-etil) benzenosulfonato \\
\hline AHADH & Enzima L- $\alpha$-hidroxiácido desidrogenase \\
\hline ALAT & Alanina aminotransferase \\
\hline ASAT & Aspartato aminotransferase \\
\hline ASCT & Succinato CoA-transferase \\
\hline ATP & Adenosina trifosfato \\
\hline BLAST & Basic Local Alignment Search Tool (Ferramenta de busca por alinhamento local) \\
\hline BSA & Albumina bovina sérica \\
\hline CPM & Contas por minuto \\
\hline CAT & L-carnitina acil-transferase \\
\hline cDNA & DNA complementar \\
\hline $\mathrm{CHO}-\mathrm{K}_{1}$ & Linhagem cellular proveniente de ovário de hamster Chinês \\
\hline CMXRos & Clorometil-X-rosamina \\
\hline CS & Citrato Sintase \\
\hline $\mathrm{Ct}$ & Threshold cycle (Ciclo limiar de detecção) \\
\hline DAPI & 4', 6-diamino-2-fenilenoindol \\
\hline DCICP & Diclorofenolindofenol \\
\hline DEAE & Dietilaminoetil celulose \\
\hline DEPC & Dietilpirocarbonato \\
\hline DMSO & Dimetilsulfóxido \\
\hline DNA & Ácido desoxirribonucléico \\
\hline DNase & Desoxirribonuclease \\
\hline $\mathrm{dNTP}$ & Desoxirribonucleosídeo trisfosfato \\
\hline DNTB & Dinitrofeniltiocianato \\
\hline DO & Densidade ótica \\
\hline DTT & Ditiotreitol \\
\hline E-64 & N-(trans-Epoxisuccinil)-L-leucina 4-guanidinobutilamida \\
\hline $\mathrm{EC}$ & Enzyme Comission (Comissão de nomenclatura de enzimas) \\
\hline EDTA & Ácido etilenodiaminotetracético \\
\hline EGTA & Ácido etilenoglicol-bis-aminoetiletertetracético \\
\hline EROs & Espécies reativas de oxigênio \\
\hline FAD & Flavina Adenosina dinucleotídeo \\
\hline G-1,3-BP & Gliceraldeído-1,3-bifosfato \\
\hline GAPDH & Gliceraldeído -3-fosfato desidrogenase \\
\hline GSA & Glutamato semi-aldeído \\
\hline GSH & Glutationa reduzida \\
\hline GSSH & Glutationa oxidada \\
\hline$\gamma-\mathrm{GK}$ & Glutamil quinase gama \\
\hline HGPRT & Hipoxantina-guanina fosforibosiltransferase \\
\hline
\end{tabular}




\begin{tabular}{|c|c|}
\hline HK & Hexoquinase \\
\hline ID & Identidade \\
\hline IFN- $\gamma$ & Interferon gama \\
\hline $\operatorname{IgG}$ & Imunoglobulina \\
\hline IPTG & Isopropil-beta-D-tiogalactopiranosídeo \\
\hline $\mathrm{Kb}$ & Quilobases (1000 pb) \\
\hline kDNA & DNA do cinetoplasto \\
\hline $\mathrm{kDa}$ & Kilodaltons \\
\hline $\mathrm{KLH}$ & Keyhole limpet hemocyanin \\
\hline $\mathrm{LDH}$ & Desidrogenase láctica \\
\hline MTT & (3-(4,5-dimetiltiazol-2-il)-2,5 difenil bromo tetrazolio), \\
\hline MOPS & Ácido 3-[N-morfolino] propanosulfônico \\
\hline $\mathrm{NADH}$ & Nicotinamina adenina dinucleotídeo reduzida \\
\hline NAD & Nicotinamida adenina dinucleotídeo \\
\hline NADP & Nicotinamida adenina dinucleotídeo fosfato \\
\hline NADPH & Nicotinamida adenina dinucleotídeo fosfato reduzida \\
\hline Ni-NTA & Ácido nitrilotriacético- Niquel \\
\hline OAT & Ornitina aminotransferase \\
\hline ORF & Open reading frame (fase aberta de leitura) \\
\hline $\mathrm{OAB}$ & Aminobenzaldeído \\
\hline PBS & Solução salina tamponada \\
\hline PCR & Polimerase chain reaction (reação em cadeia pela polimerase) \\
\hline P5C & $\Delta^{1}$-pirrolina-5-carboxilato \\
\hline $\mathrm{P} 5 \mathrm{CDH}$ & $\Delta^{1}$-pirrolina-5-carboxilato desidrogenase \\
\hline P5CR & $\Delta^{1}$-pirrolina-5-carboxilato redutase \\
\hline P5CS & ${ }^{1}$-pirrolina-5-carboxilato sintetase \\
\hline $\mathrm{PDH}$ & Piruvato desidrogenase \\
\hline PEP & Fosfoenolpiruvato \\
\hline PEPCK & Fosfoenolpiruvato carboxiquinase \\
\hline PGK & Fosfoglicerato quinase \\
\hline PK & Piruvato quinase \\
\hline POX & Prolina oxidase \\
\hline PPAR $\gamma$ & Receptores ativados por proliferação peroxisossomal gama \\
\hline PR & Prolina racemase \\
\hline PRODH & Prolina desidrogenase \\
\hline RNA & Ácido ribonucleíco \\
\hline RNAi & Ácido ribonucléico de interferência \\
\hline RNAm & Ácido ribonucléico mensageiro \\
\hline RT-PCR & Reação de polimerização em cadeia em tempo real \\
\hline SCS & Succinil-CoA sintetase \\
\hline SDS & Sódio dodecil sulfato \\
\hline SFB & Soro fetal bovino \\
\hline TAE & Tampão Tris-Acetato-EDTA \\
\hline
\end{tabular}




$\begin{array}{ll}\text { TSEB } & \text { Tampão Tris/Sucrose/EDTA } \\ \text { TAO } & \text { Oxidase alternativa de tripanossomas } \\ \text { TAT } & \text { Tirosina aminotransferase } \\ \text { TE } & \text { Tampão Tris-EDTA } \\ \text { T4C } & \text { (4R)-1,3-ácido tiazolidina-4-carboxílico } \\ \text { TBS } & \text { Tampão tris-borato SDS } \\ \text { TCA } & \text { Ácido tricloroacético } \\ \text { Tris: } & \text { Tris-(hidroxometil)-aminometano } \\ \text { TAU } & \text { Triatomine Artificial Urine (urina artificial de triatomíneo) } \\ \text { U } & \text { Unidades } \\ \mu \mathrm{g} & \text { Micrograma } \\ \mu \text { Ci } & \text { micro Curie } \\ \mu 1 & \text { Microlitro } \\ \mu \mathrm{m} & \text { Micrômetro } \\ \text { UFC } & \text { Unidade formadora de colônia } \\ \text { UV } & \text { Ultravioleta } \\ \text { UQ } & \text { Ubiquinona } \\ \text { VPF } & \text { Via das pentose fosfato } \\ X-g a l & \text { 5-bromo-4-cloro-3-indolil- } \beta \text {-D-galactopiranoside }\end{array}$




\section{SUMÁRIO}

\section{INTRODUÇÃO}

1.1 A doença de Chagas 20

1.2 O Trypanosoma cruzi 21

$\begin{array}{lll}1.3 & \text { Quimioterapia } & 24\end{array}$

1.3.1 Quimioterapia atual 24

1.3.2 Novas perspectivas quimioterápicas 26

1.4 Metabolismo intermediário do Trypanosoma cruzi 30

$1.5 \quad$ Via das pentoses fosfatos (VPF) 35

$\begin{array}{lll}1.6 & \text { Acetil -CoA } & 35\end{array}$

$\begin{array}{lll}1.7 & \text { Produção de ATP } & 37\end{array}$

1.8 O Metabolismo dos aminoácidos em tripanossomatídeos 38

1.9 O Ciclo de L-Prolina 46

$\begin{array}{ll}2 . & \text { OBJETIVOS } \\ 2.1 & \text { Objetivo geral }\end{array}$

2.2 Objetivos específicos 46

3. MATERIAIS E MÉTODOS

3.1 Microorganismos, plasmídeos e olignucleotídeos utilizados no trabalho 47

3.2 Obtenção de parasitas 49

3.2.1 Tripomastigotas de cultivo 49

3.2.2 Tripomastigotas metacíclicos 49

3.2.3 Purificação dos tripomastigotas metacíclicos 49

3.2.4 Amastigotas e epimastigotas intracelulares 50

3.2.5 Purificação de formas intracelulares 50

3.3 Manipulação de DNA $\quad 50$

3.3.1 Extração de DNA genômico de T. cruzi 50

3.3.2 Dosagem de DNA 51

3.3.3 Eletroforese em gel de agarose 51

3.3.4 Clonagem de um gene putativo da PRODH de T. cruzi 51

3.3.5 Reações de amplificação de DNA por PCR 51

3.3.6 Seqüenciamento de DNA 52

3.3.7 Digestão com enzimas de restrição, isolamento e purificação de fragmentos de DNA, ligação e seqüenciamento 52

3.3.8 Extração de DNA plasmidial em pequena escala (Mini-prep) 53

3.4 Manipulação de RNA $\quad 53$

3.4.1 Extração de RNA 53

3.4.2 Quantificação dos transcritos do gene PRODH por PCR quantitativo (qRT-PCR) 54

3.4.3 Análise dos dados $\quad 55$

3.5 Manipulação de bactérias $\quad \mathbf{5 5}$

3.5.1 Bactérias 55

3.5.2 Preparação de bactérias competentes $\quad 55$ 
3.5.3 Transformação de bactérias competentes 56

3.5.4 Expressão das proteínas recombinantes em E. coli 56

3.5.5 Purificação da PRODH recombinante 57

3.6 Manipulação de leveduras $\quad \mathbf{5 7}$

3.6.1 Leveduras 57

3.6.2 Transformação de leveduras 58

3.6.3 Quantificação de glutationa total, oxidada (GSSG) e reduzida (GSH) 58

3.7 Preparação de extratos protéicos 59

3.8 Quantificação de Proteínas 59

3.9 Obtenção de anticorpos específicos por predição da região antigênica 59

3.9.1 Purificação de anticorpo $\quad 61$

3.10 Imunolocalização $\quad 61$

3.11 Localização subcelular de PRODH em extratos protéicos de T. cruzi $\quad 62$

3.12 Western Blotting 62

3.13 Ensaios de atividades enzimáticas $\quad 63$

3.13.1 Redução de DCICP 63

3.13.2 Cinética Enzimática 63

3.13.3 Detecção de pirrrolina-5-carboxilato por reação com o-Aminobenzaldeído 63

3.13.4 Ensaios de atividade da PRODH com diferentes cofatores 64

3.13.5 Atividade da enzima citrato sintase 64

3.13.6 Atividade da enzima piruvato quinase (PK) 64

3.13.7 Atividade da enzima hexoquinase (HK) 65

$\begin{array}{ll}3.14 & \text { Ensaio de ligação ao } \mathrm{Ca}^{2+}\end{array}$

3.15 Ensaios de estresse oxidativo

3.15.1 Em leveduras 66

3.15.2 Em epimastigotas de T.cruzi $\quad 67$

$\begin{array}{lll}3.15 .3 & \text { Ensaio de MTT } & 67\end{array}$

3.15.4 Dosagem de prolina intracelular livre 68

3.16 Avaliação de análogos de prolina $\quad \mathbf{6 8}$

3.16.1 Ensaio de inibição do crescimento de epimastigotas de T.cruzi 68

3.16.2 Efeito do análogo T4C na inibição do crescimento de epimastigotas de T. cruzi 69 sob estresse oxidativo.

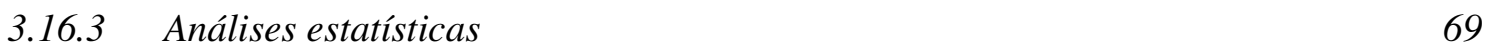

3.16.4 Atividade enzimática da PRODH/PR e transporte de prolina 70

3.17 Preparação de fração mitocondrial de $T$. cruzi $\quad 70$

3.18 Determinação da participação da PRODH no controle respiratório 71

3.18.1 Medida do consumo de oxigênio $\quad 71$

3.18.2 Determinação do controle respiratório com succinato ou L-prolina como Substratos para o complexo II da cadeia respiratória 71

4 RESULTADOS

4.1 Clonagem da PRODH

$\begin{array}{lll}4.2 & \text { Análises in silico } & \mathbf{7 4}\end{array}$

4.3 Complementação da PRODH em S. cerevisiae 79 
4.4 Análise do perfil transcricional da PRODH ao longo do ciclo de vida 85 do T. cruzi

4.5 Localização Subcelular da PRODH 87

4.6 Expressão e purificação da PRODH 92

4.7 Caracterização da PRODH 93

4.8 A possível regulação da atividade da PRODH recombinante por $\mathrm{Ca}^{2+} \quad 97$

4.9 Ensaios de estresse oxidativo 99

4.9.1 Ensaios com leveduras complementadas 99

4.9.2 Ensaios com epismastigotas de T. cruzi 103

$\begin{array}{lll}\text { 4.10 Participação da prolina na cadeia respiratória } & 111\end{array}$

5 DISCUSSÃO

5.1 Atividade da PRODH de T. cruzi 115

5.2 Análises in silico do domínio putativo EF- hand presente na PRODH 116 de $T$. cruzi

5.3 Análise funcional do domínio EF-hand: a possível regulação da PRODH 118 de $T$. cruzi por $\mathrm{Ca}^{2+}$ ou $\mathrm{Mg}^{2}$

5.4 Localização e perfil da PRODH de T. cruzi ao longo do ciclo de vida 120

$\begin{array}{lll}5.5 & \text { Perfil de expressão do gene PRODH } & 121\end{array}$

5.6 Complementação de levedura com PRODH de T.cruzi 122

5.7 Participação da PRODH em mecanismos de resistência a estresse 123 xidativo

5.8 Efeito de Inibidores da enzima PRODH 124

$\begin{array}{lll}5.9 & \text { Participação da prolina na cadeia respiratória } & 125\end{array}$

5.10 A via prolina - glutamato em $T$. cruzi: uma proposta 127

6 CONCLUSÕES 129

REFERÊNCIAS 


\section{INTRODUÇÃO}

\subsection{A doença de Chagas}

A Tripanossomíase Americana ou doença de Chagas, descrita pela primeira vez em 1909 por Carlos Chagas (CHAGAS, 1909), é causada pelo protozoário hemoflagelado Trypanosoma cruzi, pertencente à ordem Kinetoplastida e à família Trypanosomatidae (HOARE, 1972). Estima-se que há cerca de 10 milhões de pessoas infectadas nas Américas, desde o sul dos Estados Unidos ao sul da Argentina e Chile, causando aproximadamente 10 mil mortes a cada ano, sendo que 40 milhões de indivíduos ainda vivem em área de risco (WHO, 2002).

A doença de Chagas é transmitida ao hospedeiro vertebrado, em condições naturais, principalmente por insetos pertencentes à ordem Hemiptera, família Reduviidae, subfamília Triatominae. As espécies de maior importância epidemiológica são Triatoma infestans, Rhodnius prolixus e Panstrongylus megistus (BARRET et al., 2003). A principal via de transmissão da doença é a vetorial, e acontece pelo contato da pele e mucosas com fezes ou urina de insetos hematófagos contaminados por T. cruzi. Todavia, a transmissão por via oral, através de ingestão de alimentos contaminados com fezes do vetor infectado, tornou-se uma rota de transmissão de grande importância epidemiológica no Brasil (COURA, 2006; DIAS, et al., 2008). As outras vias de transmissão incluem a transfusão sanguínea, os transplantes de órgãos, a transmissão congênita e os acidentes de laboratório (RIBEIRO; RISSATO E GARCIA; BONOMO, 1987; BITTENCOURT, 1992; MONCAYO, 1999; DIAS, 2009).

A doença de Chagas apresenta duas fases clínicas em humanos: aguda e crônica. As características de cada fase, assim como o curso da infecção, dependem de diversos fatores ligados ao parasito e ao hospedeiro. Dentre os fatores relacionados ao parasito, podem-se citar a variabilidade genética das cepas, inóculo e virulência; já os fatores relacionados ao hospedeiro são a rota de transmissão, o estado imunológico, idade, sexo e ambiente (BRENER, 1985; ANDRADE et al., 2002).

A fase aguda da doença inicia-se quando o parasito entra no hospedeiro mamífero. Durante essa fase, a parasitemia é patente, mas a infecção é geralmente assintomática. Nos casos sintomáticos, podem ser observados febre, dor de cabeça, edema, enfartamento ganglionar e sinais da porta de entrada (sinal de Romaña). Em alguns casos, ainda podem

ser observados uma miocardite severa e comprometimento neurológico, o que 
eventualmente pode levar ao óbito. A maioria dos indivíduos sobrevive à fase aguda e evolui para a fase crônica (PUNUKOLLU et al., 2007).

As principais formas da fase crônica são a indeterminada, a cardíaca (cardiopatia chagásica crônica) e a digestiva. A forma indeterminada ou assintomática é caracterizada pela ausência evidente de lesões teciduais ou mau funcionamento de órgãos. Essa forma da doença pode durar vários meses ou perdurar por toda a vida do paciente. A patologia cardíaca é caracterizada pela miocardite crônica que leva à cardiomegalia, insuficiência cardíaca congestiva, arritmias e tromboembolismos (PINTO DIAS, 1990; PRATA, 1994). A forma digestiva consiste na dilatação do esôfago e/ou cólon (megaesôfago e/ou megacólon). Cerca de $70 \%$ dos indivíduos infectados apresentam a forma crônica indeterminada, já os $30 \%$ restantes desenvolvem uma das formas crônicas sintomáticas da doença (cardíaca e digestiva), as quais podem levar à morte. Assim, a maioria dos indivíduos infectados permanece assintomática durante toda a vida, e somente uma percentagem da população desenvolve os sintomas severos da doença (MONCAYO; ORTIZ YANINE, 2006; BOSCARDIN et al., 2010).

Avanços importantes têm sido feitos no controle vetorial/transfusional para a eliminação da doença (MONCAYO, 1999; DIAS, 2006; SCHOFIELD; JANNIN; SALVATELLA, 2006; COURA; DIAS, 2009; REITHINGER et al., 2009). Porém, os resultados dessas medidas não beneficiam diretamente os milhões de indivíduos já infectados, sejam aqueles que apresentam a forma indeterminada ou aqueles que apresentam manifestações clínicas da doença. De fato, mesmo após um século de sua descoberta, problemas como limitações nos métodos de diagnóstico e quimioterapia, tornam a doença de Chagas um grande problema de saúde pública nas Américas, o que ressalta a necessidade de um esforço contínuo na busca de novas alternativas terapêuticas, vacinais e de diagnóstico.

\subsection{O Trypanosoma cruzi}

O T. cruzi possui um complexo ciclo de vida em hospedeiros vertebrados e invertebrados. Nos diversos estágios de seu ciclo de vida, o parasito apresenta diferentes características morfológicas e metabólicas que lhe permitem se adaptar a cada novo ambiente (TYLER; ENGMAN, 2001; ALVES; COLLI, 2007).

Há quatro formas clássicas descritas na literatura: epimastigota e tripomastigota metaciclíco (encontrados no tubo digestivo do inseto vetor), amastigota (intracelular) e

tripomastigota (presentes na circulação sanguínea dos hospedeiros mamíferos) 
(BRENER, 1973). Outras formas evolutivas intermediárias também têm sido descritas ao longo do ciclo de vida de T. cruzi. No sangue periférico do mamífero, pode existir uma população pleomórfica de tripomastigotas, constituída de uma mistura de duas morfologias básicas descritas como slender e broad (TYLER; ENGMAN, 2001). A forma epimastigota intracelular, detectada no citoplasma das células infectadas do hospedeiro vertebrado e em culturas de tecidos, aparece de maneira transiente entre os estágios amastigota e tripomastigota (ALMEIDA-DE-FARIA et al., 1999). Além disso, no intestino médio do inseto, as formas tripomastigotas sangüíneas, durante sua diferenciação em epimastigotas, passam por uma forma intermediária descrita como esferomastigota (BRACK, 1968; DE SOUZA, 1984). Todos esses estágios do ciclo de vida do parasito podem ser identificados a partir de características morfométricas, tais como a forma do parasito e a posição do cinetoplasto em relação ao núcleo e pela região emergente do flagelo (HOARE, 1966).

O ciclo biológico no hospedeiro vertebrado inicia-se quando as formas tripomastigotas metacíclicos, presentes na porção terminal do tubo digestivo e eliminadas nas fezes e urina do inseto vetor (barbeiro) durante o repasto sanguíneo, penetram através da pele por lesões, da mucosa ocular, ou até mesmo por via oral (alimentos contaminados) (BRENER, 1971; BARRETT et al., 2003; COURA, 2006). Ao penetrar no hospedeiro, os tripomastigotas metacíclicos são capazes de atingir os tecidos subcutâneos ou subjacentes às mucosas, podendo infectar diferentes tipos celulares, principalmente os macrófagos (TANAKA; TANOWITZ; BLOOM, 1983; DE ARAUJOJORGE, 1989). O parasito invade as células do hospedeiro através de um vacúoloparasitóforo, onde tem início o processo de diferenciação (SCHENKMAN et al., 1988; BURLEIGH; ANDREWS, 1995). O parasito pode escapar deste vacúolo e alcançar o citoplasma celular onde irá se diferenciar em amastigota. Através de sucessivas fissões binárias, as formas amastigotas multiplicam-se dentro da célula e diferenciam-se em epimastigotas intracelulares (ALMEIDA-DE-FARIA et al., 1999). Posteriormente, as formas epimastigotas intracelulares dão origem às formas tripomastigotas (a forma infectiva do parasito), as quais são liberadas para o meio extracelular por meio da ruptura da célula hospedeira. Uma vez liberados, os tripomastigotas podem invadir células vizinhas ou atingir a corrente sanguínea, através da qual podem invadir células de outros tecidos do hospedeiro ou serem ingeridos pelo inseto vetor durante o próximo repasto (BARRETT et al., 2003). 
Uma vez ingeridos com o sangue pelo hospedeiro invertebrado, os parasitos migram para o intestino do inseto vetor, onde diferenciam-se e multiplicam-se como formas epimastigotas. Em seguida, essas formas migram para a parte posterior do tubo digestivo atingindo o reto, onde diferenciam-se em tripomastigotas metacíclicos (metaciclogênese), que, num novo repasto sanguíneo, são eliminados com as fezes e urina do inseto triatomíneo. Ao entrar em contato com um novo hospedeiro mamífero e estabelecer um novo processo de infecção de suas células, o ciclo se fecha (SILBER et al., 2005; ALVES; COLLI, 2007) (Figura 1).

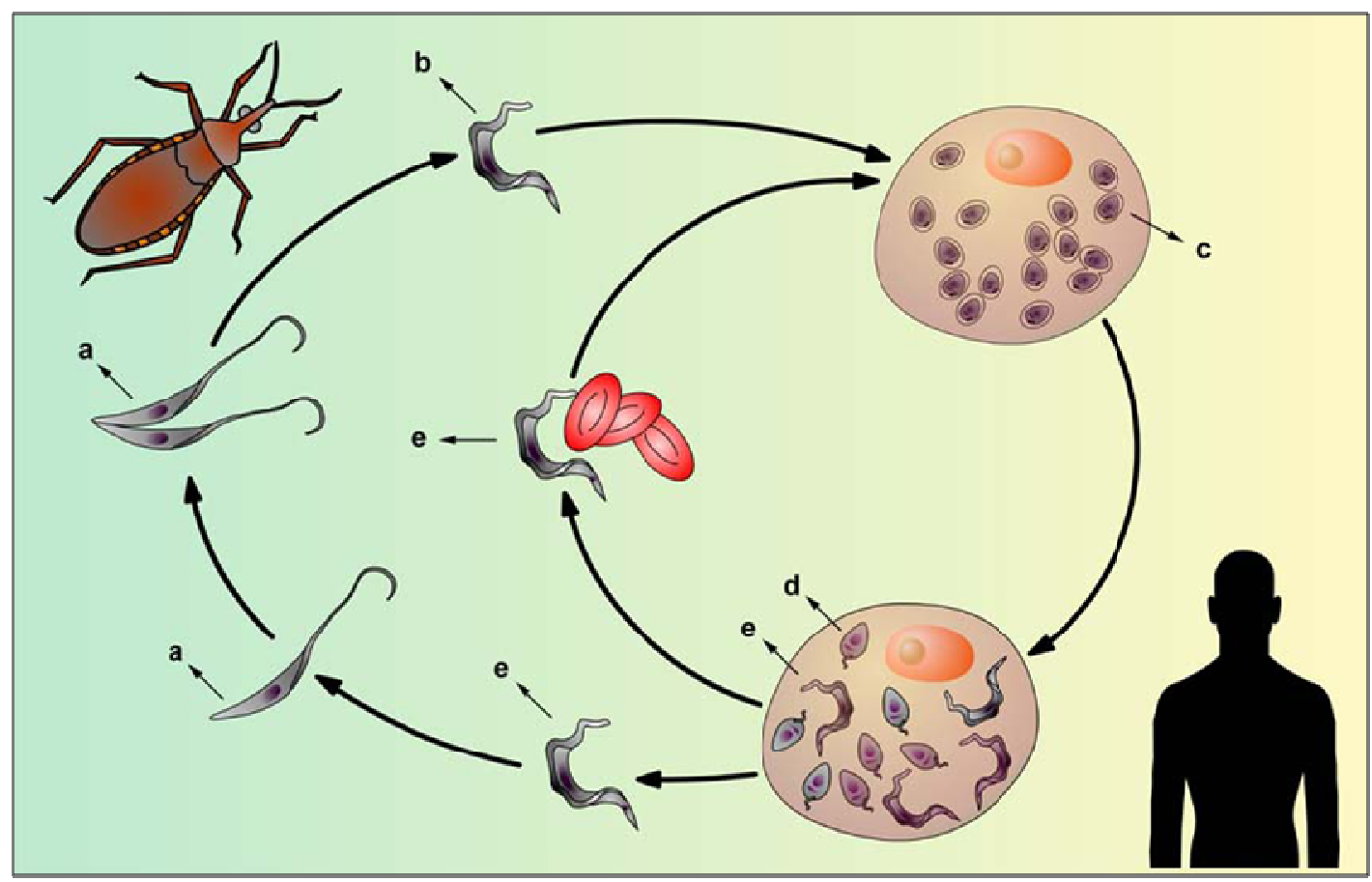

Figura 1. Representação esquemática do ciclo de vida do Trypanosoma cruzi. Formas epimastigotas replicativas e não replicativas, presentes no inseto vetor (a). Formas infectivas, eliminadas nas fezes e urina do hospedeiro invertebrado (b). As formas tripomastigotas metacíclicas invadem as células do hospedeiro vertebrado e diferenciam-se nas formas amastigotas (c), dando origem ao estágio transiente denominado epimastigota intracelular (d), que se diferencia em tripomastigotas (e). Os tripomastigotas podem disseminar através da corrente sanguínea do mamífero. O ciclo se completa quando estas últimas diferenciam-se novamente em formas epimastigotas, as quais colonizam o tubo digestivo de um novo inseto vetor durante o repasto sanguíneo.

Fonte: Boscardin et al. (2010). 
Embora o T. cruzi compartilhe aspectos da organização celular típica da maioria dos eucariotos, existem algumas diferenças estruturais relevantes, como a presença do glicossomo, uma organela onde acontece a primeira fase da via glicolítica, dos reservossomos, organela que têm a função de armazenar proteínas exógenas e possuem alta atividade de hidrolases (CAZZULO, 1994; URBINA, 1994; CAZZULO; STOKA; TURK, 1997) e dos acidocalcissomas, organelas acídicas com alta concentração de fósforo (pirofosfato e polifosfato) complexado com $\mathrm{Ca}^{2+}$ e outros íons (DOCAMPO; MORENO, 2001; DOCAMPO; ULRICH; MORENO, 2010). Além disso, o parasito possui uma única mitocôndria que ocupa grande parte do seu volume celular, cujo DNA (kDNA) está contido em uma estrutura específica denominada cinetoplasto. O kDNA é organizado em moléculas denominadas maxicírculos e minicírculos. Poucas dezenas de maxicírculos contêm os genes que codificam proteínas e RNAs mitocôndriais. Os milhares de minicírculos codificam os RNAs guias (RNAg), os quais atuam no processo de edição dos transcritos dos genes dos maxicírculos (LIU et al., 2005; LIU et al., 2009).

\subsection{Quimioterapia}

\subsubsection{Quimioterapia atual}

Desde a descoberta da doença de Chagas (1909) muitos estudos propuseram encontrar uma droga eficaz no tratamento da doença. Sendo assim, inúmeras substâncias químicas, extratos naturais e misturas de componentes foram avaliados a fim de descobrir algum efeito quimioterápico. Contudo, somente no final de 1960 e início de 1970, dois compostos surgiram apresentando novas perspectivas para o tratamento da doença de Chagas. Esses são o benzonidazol, distribuido no Brasil com o nome comercial de

Rochagan $^{\circledR}$ e o nifurtimox, distribuido no Brasil com o nome comercial de Lampit ${ }^{\circledR}$ (COURA, 1996; URBINA, 2002; PINTO DIAS, 2006; COURA, 2009).

Muitos estudos clínicos têm mostrado que ambas as drogas têm atividade significativa na fase aguda, com até $80 \%$ de cura parasitológica em pacientes tratados (sendo que a cura é definida com a negativação dos testes parasitológicos e sorológicos convencionais). No entanto, essa eficácia varia de acordo com a área geográfica (em virtude da grande variabilidade de cepas de T. cruzi em circulação nas áreas endêmicas), com os diferentes níveis de virulência e parasitismo e, em grande parte, pelo surgimento de cepas resistentes aos tratamentos com essas drogas (FILARDI; BRENER, 1987; ANDRADE et al., 1992; CANCADO, 1999; URBINA, 2002). 
A principal limitação das drogas avaliadas é a baixa atividade antiparasitária durante a fase crônica da doença, em que menos de $80 \%$ dos pacientes tratados não são curados parasitologicamente. Recentemente, uma série de estudos utilizando modelo de infecção murino mostrou que as drogas previnem o desenvolvimento da cardiomiopatia crônica e induz a remoção do patógeno, resultando na proteção estável de células $\mathrm{T}$ de memória (TARLETON, 2003; GARCIA et al., 2005; BUSTAMANTE; BIXBY; TARLETON, 2008). Além disso, ambas as drogas são citotóxicas e até mesmo genotóxicas (CANCADO, 2002; POLI et al., 2002)

O modo de ação preciso dessas drogas não está claro em tripanossomatídeos, mas evidências experimentais indicam que a ação antiparasitária do nifurtimox está associada à geração de espécies reativas de oxigênio (EROs), tais como ânion superóxido e peróxido de hidrogênio. Por outro lado, o principal modo de ação do benzonidazol está relacionado à formação de derivados reativos intermediários, como o radical nitroânion e metabólitos eletrofílicos (derivados nitroso e hidroxilamina) (DOCAMPO, 1990; MAYA et al., 2007; DIAS et al., 2009). Ambos, nifurtimox e benzonidazol, funcionam de fato como prodrogas, sendo compostos nitro-heterocíclicos, com o grupo nitro ligado ao anel furano ou imidazol, respectivamente. $\mathrm{O}$ grupo nitro $\left(\mathrm{NO}_{2}\right)$ presente nestas moléculas é reduzido ao grupo amino $\left(-\mathrm{NH}_{2}\right)$ pela ação de enzimas do tipo nitroredutases. Esse processo, iniciado pela reação catalisada pela citocromo P450 redutase dependente de NADPH (EC 1.6.2.4) leva à formação de hidroxilamina (R-NHOH). No caso do nifurtimox, o radical reduz o oxigênio molecular $\left(\mathrm{O}_{2}\right)$ formando o íon superóxido $\left(\mathrm{O}_{2}{ }^{-{ }^{-}}\right)$e regenerando o grupo $\mathrm{NO}_{2}$ num ciclo redox onde o íon superóxido formado é captado pela enzima superóxido dismutase (EC 1.15.1.1), gerando peróxido de hidrogênio $\left(\mathrm{H}_{2} \mathrm{O}_{2}\right)$. O $\mathrm{H}_{2} \mathrm{O}_{2}$, através da reação de Haber-Weiss, na presença de íons $\mathrm{Fe}^{\mathrm{III}}$, forma o radical hidroxila $(\cdot \mathrm{OH})$. A esta espécie tem sido atribuído o efeito tripanocida por mecanismos complexos que envolvem ligação a lipídios, proteínas e ao DNA do T. cruzi (URBINA, 2002; MAYA et al., 2007). Ao contrário do nifurtimox, o benzonidazol não atua através do ciclo redox e não depende diretamente de espécies reativas de oxigênio (EROs). Nesse caso, o efeito tripanocida tem sido atribuído à ligação covalente do radical nitro com macromoléculas do T. cruzi, tais como DNA e citocromo P450 (DIAZ DE TORANZO et al., 1988). Há ainda relatos de que o benzonidazol aumenta a fagocitose e lisa o T. cruzi através de um mecanismo dependente de interferon-gama (IFN- $\gamma$ ) (REVELLI et al., 1999), além de inibir o crescimento do parasito através da inibição da enzima NADH- 
fumarato redutase (EC 1.3.1.6) (TURRENS et al., 1996). Em síntese, as espécies químicas geradas por estas drogas são altamente reativas e podem afetar outras moléculas, especialmente do hospedeiro vertebrado. Essa baixa especificidade de ação sobre o parasito contribui para os efeitos citotóxicos observados no tratamento dos pacientes (PEDROSA et al., 2001; DIAS et al., 2009).

\subsubsection{Novas perspectivas quimioterápicas}

Avanços consideráveis foram feitos no conhecimento da bioquímica, genética e biologia celular/molecular do $T$. cruzi, incluindo o seqüenciamento do genoma deste patógeno. Essas informações contribuiram para a identificação de um largo número de alvos biológicos promissores para a ação de drogas com potencial terapêutico. A seguir serão apresentados alguns exemplos que atualmente estão sendo investigados.

\section{a) Biossíntese de esteróis}

O T. cruzi requer esteróis específicos para sua viabilidade celular e proliferação em todos os estágios do seu ciclo de vida. Esse parasito, assim como fungos, sintetiza ergosterol, mas não colesterol. Portanto, as etapas da biossíntese de esteróis em T. cruzi são divergentes em relação à síntese realizada por células de mamíferos. Atualmente, as enzimas mais bem estudadas dessa via metabólica são a esterol 14-demetilase (EC 1.14.13.70), lanoesterol sintase (EC 5.4.99.7), esqualeno epoxidase (EC 1.14.99.7), esqualeno sintase (EC 2.5.1.21), D-24(25) esterol metiltransferase (EC 2.1.1.43), farnesilpirofosfato sintase (EC 2.5.1.10) e a farnesiltransferase (EC 2.5.1.58). Dentre os inibidores mais representativos da síntese de ergosterol estão os derivados triazólicos, tais como cetoconazol, fluconazol, itraconazol, albaconazol, TAK-187, posaconazol e ravuconazol (URBINA, 2009a).

Os derivados triazólicos demonstraram atividade in vitro e capacidade de curar animais, em condições de modelagem das fases aguda e crônica da doença de Chagas. Em alguns casos relatou-se a capacidade de curá-los quando infectados com cepas de $T$. cruzi resistentes a nifurtimox e benzonidazol, e até mesmo hospedeiros imunosuprimidos (URBINA et al., 2003; DE SOUZA; RODRIGUES, 2009; WILKINSON; KELLY, 2009).

\section{b) Cisteínas proteases}

As cisteínas proteases de T. cruzi participam de muitos processos celulares, tais como metabolismo energético, diferenciação, invasão da célula hospedeira e evasão do sistema imune (CAZZULO, 2002). A mais abundante proteína da família de cisteína- 
proteases em $T$. cruzi é a cruzipaina (responsável pela maior parte da atividade proteolítica em todas as fases do ciclo evolutivo do parasito) (CAMPETELLA; MARTINEZ; CAZZULO, 1990). A principal classe de inibidores seletivos desta protease são os derivados peptídicos, especialmente o dipeptídeo vinil sulfona. Este inibidor é capaz de bloquear, in vitro, a proliferação de epimastigotas extracelulares, amastigotas intracelulares e a metaciclogênese (CAFFREY; SCORY; STEVERDING, 2000). Também foram capazes de reduzir os níveis de parasitemia e prolongar a sobrevivência de camundongos, em condições de modelagem das fases aguda e crônica da doença de Chagas, com toxicidade mínima (ENGEL et al., 1998; MCKERROW; ENGEL; CAFFREY, 1999). Camundongos imunosuprimidos na fase aguda da doença também responderam ao tratamento com esses inibidores (DOYLE et al., 2007). Muitos estudos têm identificado novas estruturas com potencial atividade inibitória in vitro e in vivo contra a cruzipaína, como por exemplo, inibidores não-peptídicos, como os semicarbazonas, tiosemicarbazonas, acil e aril-oximetil cetona e quinoxalina-Nacilhidrazona (BRAK et al., 2008; GUIDO et al., 2008; ROMEIRO et al., 2009).

\section{c) Metabolismo depedendente de grupos tióis}

Apesar do T. cruzi não possuir nenhuma catalase ou glutationa peroxidase, e a atividade da superóxido dismutase ser muito reduzida, esses parasitos apresentam um sistema de detoxificação eficiente contra EROS, que envolve o tiol tripanotiona (uma poliamina conjugada presente em cinetoplastídeos) (WILKINSON et al., 2000; IRIGOIN et al., 2008). Dessa forma, uma redução nos níveis dos tióis antioxidantes de T. cruzi o tornaria altamente susceptível aos efeitos de radicais livres, tais como $\mathrm{NO} \bullet, \mathrm{O} 2 \bullet-$ ou ONOO-.

Uma variedade de famílias de compostos nitrofuranos, naftoquinonas, compostos tricíclicos (usados como antidepressivos) e nitrofurfuril têm sido estudadas como potenciais inibidores da formação de grupos tióis. Muitos desses compostos já foram identificados como inibidores da enzima tripanotiona redutase, com atividade tripanocida in vitro. Contudo, ainda faltam evidências sobre eficiência de tais compostos in vivo, bem como estudos sobre a re-captação das drogas e/ou metabolismo dos compostos a serem desenvolvidos (GARFORTH et al., 1997; RIVAROLA; PAGLINI-OLIVA, 2002; AGUIRRE et al., 2004; URBINA, 2009b). 


\section{d) Metabolismo de pirofosfato}

Como já mencionado, os tripanossomatídeos possuem organelas especializadas, chamadas de acidocalcissomas, que estão envolvidas no armazenamento de cátions e polifosfato. As cadeias curtas de polifosfato estão envolvidas na resposta desses microrganismos aos estresses do meio, osmorregulação e energia (DOCAMPO; MORENO, 1999). A entrada e liberação de $\mathrm{Ca}^{2+}$ na matriz dos acidocalcissomas é regulada por uma série de mecanismos, incluindo atividades $\mathrm{Ca}^{2+} \mathrm{ATPase}, \mathrm{H}^{+} \mathrm{ATPases}$, bombas de $\mathrm{Na}^{+} / \mathrm{H}^{+}$e pirofosfatos (DOCAMPO; MORENO, 2001a). Os bisfosfonatos (análogos inorgânicos do pirofosfato) acumulam-se nos acidocalcissomas do parasito e podem inibir as enzimas envolvidas nas reações dos pirofosfatos orgânico e inorgânico (farnesilpirofosfato sintase e farnesil transferase). Tais compostos apresentaram atividade seletiva in vitro contra $T$. cruzi, e têm sido capazes de reduzir a parasitemia em camundongos (DOCAMPO; MORENO, 2001b; ESTEVA et al., 2005). Dentre os inibidores da proteína farnesil transferase, os derivados R-fenilalanina e N-propilpirazinil têm se mostrado promissores em ensaios in vitro, prolongando a sobrevivência de animais infectados com T. cruzi (MORENO; DOCAMPO, 2009).

\section{e) Metabolismo de purinas e síntese de nucleotídeos}

Os tripanossomatídeos são parasitos auxotróficos para purinas e deficientes na via de recuperação desta base, ao contrário do que acontece com os hospedeiros vertebrados. Em T. cruzi, proteínas envolvidas nessa via metabólica são alvos de drogas, incluindo hipoxantina-guanina fosforibosiltransferase (HGPRT) (AVILA; AVILA; MUNOZ, 1981; NAKAJIMA-SHIMADA; HIROTA; AOKI, 1996), dihidrofolato redutase (KHABNADIDEH et al., 2005), pteridina redutase e dihidroorotato desidrogenase (NARA et al., 2005).

O Alopurinol é uma droga utilizada no tratamento da gota em humanos, e em tripanossomatídeos esse composto age como um análogo de purina. Essa droga é incorporada, através da HGPRT, no DNA dos parasitos, interferindo na síntese de RNA e proteínas (AVILA; AVILA; MONZON, 1984). Embora o Alopurinol seja ativo em diferentes modelos animais, para a fase aguda da doença de Chagas, têm sido descritas diferenças de susceptibilidade à droga entre as diversas cepas de T. cruzi (AVILA; AVILA; MONZON, 1981). Além disso, na literatura existem relatos conflitantes quanto à eficácia terapêutica de Alopurinol em humanos (APT et al., 2005). 


\section{f) Trans-sialidases}

As trans-sialidases, membros de uma superfamília de glicoproteínas de superfície do T. cruzi (DIAS et al., 2009), são enzimas que catalisam a transferência de ácido siálico dos glicoconjugados das proteínas do meio extracelular para as moléculas de mucina que recobrem a superfície do parasito (PEREIRA-CHIOCCOLA; SCHENKMAN, 1999). Como o T. cruzi é incapaz de sintetizar o ácido siálico, o único mecanismo de sialilação das suas glicoproteínas de membrana consiste na transferência deste açúcar a partir dos glicoconjugados das células hospedeiras através da ação dessas enzimas, o que as torna um alvo promissor (NERES; BRYCE; DOUGLAS, 2008; NERES et al., 2009).

\section{g) Topoisomerases e kDNA}

As enzimas e proteínas envolvidas na replicaçao de DNA têm sido exploradas como alvos de inibidores seletivos. As Topoisomerases I, envolvidas na replicação nuclear do DNA (BODLEY; SHAPIRO, 1995), e a Topoisomerase II, envolvida na replicação do DNA do cinetoplasto (GOLDENBERG; FRAGOSO; GONZALESPERDOMO, 1993), têm sido testadas como alvos, e seus inibidores foram eficientes em bloquear o crescimento de T. cruzi. Além disso, substâncias intercalantes e ligantes de DNA, com atividade tripanocida, têm se mostrado agentes promissores contra o parasito (ROWLAND et al., 2003; STOLIC et al., 2009).

\section{h) Via glicolítica}

As enzimas envolvidas na via glicolítica são consideradas alvos potenciais para inibição seletiva, pois a sua inibição levaria à redução da geração de energia (através da diminuição da produção de ATP) no parasito. Podem-se destacar pelo menos três enzimas que têm sido bastante exploradas como alvos nessa via: a gliceraldeído-3-fosfato desidrogenase (GAPDH, EC 1.2.1.12), a hexoquinase (EC 2.7.1.1) e a fosfofrutoquinase (EC 2.7.1.11) (URBINA; CRESPO, 1984; SOUZA et al., 1998). Dentre essas enzimas, a GAPDH tem sido alvo de muitos estudos e vários inibidores de origem natural e sintética têm sido propostos (DIAS et al, 2009). Dentre esses, destacam-se as cumarinas, flavonóides e ácidos anacárdicos de origem natural, os compostos sintéticos como os nucleosídeos e os intermediários reativos de nitrogênio (óxido nítrico, nitroxil e peroxinitrito) (URBINA, 2009b). Porém, alguns dados mostram que a glicólise poderia não ser uma via ativa nos estágios intracelulares de T. cruzi, o que torna a eficiência da utilização desses alvos controversa (SILBER et al., 2009). 


\section{i) Vias relacionadas a aminoácidos}

Muitas pecularidades têm sido identificadas no metabolismo de aminoácidos, o que fez com que essas vias começassem a ser explorada para o desenvolvimento de novas drogas (SILBER et al., 2005). A arginina quinase (PEREIRA et al., 1999) e a prolina racemase (CHAMOND et al., 2005) de T. cruzi, ambas ausentes em hospedeiros mamíferos, tem se mostrado interessantes alvos para a terapia da doença de Chagas. Os transportadores de prolina também podem ser alvos relevantes (MAGDALENO et al., 2009). O estudo dos transportadores e enzimas relacionadas ao metabolismo de aminoácidos torna-se importante para o desenvolvimento de novas drogas com potencial terapêutico, uma vez que os mesmos participam de uma variedade de processos importantes para a sobrevivência do parasito (SILBER et al., 2005).

\subsection{Metabolismo intermediário do Trypanosoma cruzi}

Os tripanosomatídeos apresentam um ciclo de vida que alterna em diferentes ambientes (exemplo: o trato intestinal do inseto, o sangue do hospedeiro vertebrado e o citoplasma celular do hospedeiro). A sua sobrevivência depende da sua habilidade de manter a homeostase intracelular de íons e nutrientes e de catabolizar diferentes substratos para obter energia. Por isso, os tripanosomatídeos são capazes de utilizar carboidratos e aminoácidos como fontes de carbono e energia (CAZZULO, 1992, 1994; SILBER et al., 2005)

A glicólise em $T$. cruzi apresenta características diferenciadas em relação a outros eucariontes. Em muitos organismos, a transição da anaerobiose para a aerobiose é acompanhada por uma rápida diminuição na taxa de utilização de glicose, está inibição do fluxo glicolítico pela presença do oxigênio é conhecida como "Efeito Pasteur". No entanto, neste organismo, não se verifica a ocorrência do "Efeito Pasteur", ou seja, ocorrem taxas parecidas do consumo de glicose tanto em anaerobiose quanto em condições aeróbicas, o que é característico de um metabolismo do tipo fermentativo. Devido a este fato, propuseram-se os termos "fermentação aeróbica" ou "fermentação succínica” da glicose para descrever o processo de oxidação da glicose (CAZZULO, 1992, 1994).

Nessas condições, a glicose é degradada incompletamente, resultando em uma mistura final de $\mathrm{CO}_{2}$, ácidos mono e dicarboxílicos, dos quais o succinato representa cerca de $70 \%$, e pequenas quantidades de acetato e piruvato. Quando existe um excesso 
de $\mathrm{NH}_{3}$ proveniente do metabolismo de aminoácidos, o $\mathrm{NH}_{3}$ é transferido a piruvato por transaminação, rendendo alanina. Isso ocorre apesar desses parasitos terem ativos a via glicolítica, o Ciclo de Krebs e a cadeia de transporte de elétrons (CANNATA; CAZZULO, 1984; CAZZULO et al., 1985; COUSTOU et al., 2008).

Outros fatos interessantes que diferenciam a glicólise deste organismo daquela de outros eucariotos são os pontos de controle e regulação. A via glicolítica, nesses parasitos, não está regulada alostericamente nos pontos clássicos de controle (hexoquinase e fosfofrutoquinase) e a oxidação da glicose acontece até gliceraldeído-1,3bifosfato (G-1,3-BP) (URBINA; CRESPO, 1984) no glicossomo (OPPERDOES; BORST, 1977). Outra característica apresentada no metabolismo de T. cruzi está relacionada à presença de pontos de ramificação na via glicolítica em nível do fosfoenolpiruvato (PEP), como explicado a seguir (Figura 2 e Figura 3).

No glicossomo, cada molécula de glicose é rapidamente convertida a duas moléculas de gliceraldeído 1,3-bifosfato, o qual é transportado para o citossol (por um sistema ainda não caracterizado) e convertido a fosfoenolpiruvato (PEP) que pode seguir diferentes vias:

I) Pode converter-se a piruvato pela piruvato quinase citosólica (PK), que por sua vez, pode ser translocado direto para a mitocôndria para entrar no Ciclo de Krebs ou formar alanina.

II) Parte pode ser transformado em alanina por transaminação no próprio citoplasma (URBINA; CRESPO, 1984; ENGEL et al., 1987; CAZZULO, 1992).

III) Ou pode ser transportado de volta para o glicossomo, seguida pela carboxilação do PEP para oxolacetato, reação catalisada pela fosfoenolpiruvato carboxiquinase (PEPCK). O oxalacetato resultante é finalmente convertido a L-malato pela malato desidrogenase glicossomal. Sob condições aeróbicas, o malato deixa o glicossomo e converte-se em fumarato. O fumarato é finalmente reduzido a succinato (um dos principais produtos de excreção em tripanossomatídeos) por alguma das duas isoformas da fumarato redutase (glicossomal e citoplasmática). Alternativamente, como um ponto desta ramificação metabólica, o malato pode ser novamente convertido a piruvato no citosol pela enzima málica I, ou transportado para a mitocôndria, onde pode ser convertido em piruvato pela enzima málica II e oxidado pelo Ciclo de Krebs (Acetil-CoA). Uma parte significativa da reserva de piruvato pode ser convertida a L-lactato (sob condições anaeróbicas) ou a Lalanina por transaminação, neste caso na mitocôndria (CANNATA et al., 1979; 
CANNATA; CAZZULO, 1984; BOVERIS; HERTIG; TURRENS, 1986; SPITZNAGEL et al., 2009). O retorno do PEP citosólico para o glicossomo via PEPCK ajuda a manter o balanço redox e o balanço ATP/ADP. Além disso, a produção de succinato através das enzimas malato e fumarato desidrogenase funciona como um mecanismo de re-oxidação de NADH de reserva (sob condições aeróbicas) (HANNAERT et al., 2003; BRINGAUD; RIVIERE; COUSTOU, 2006). 


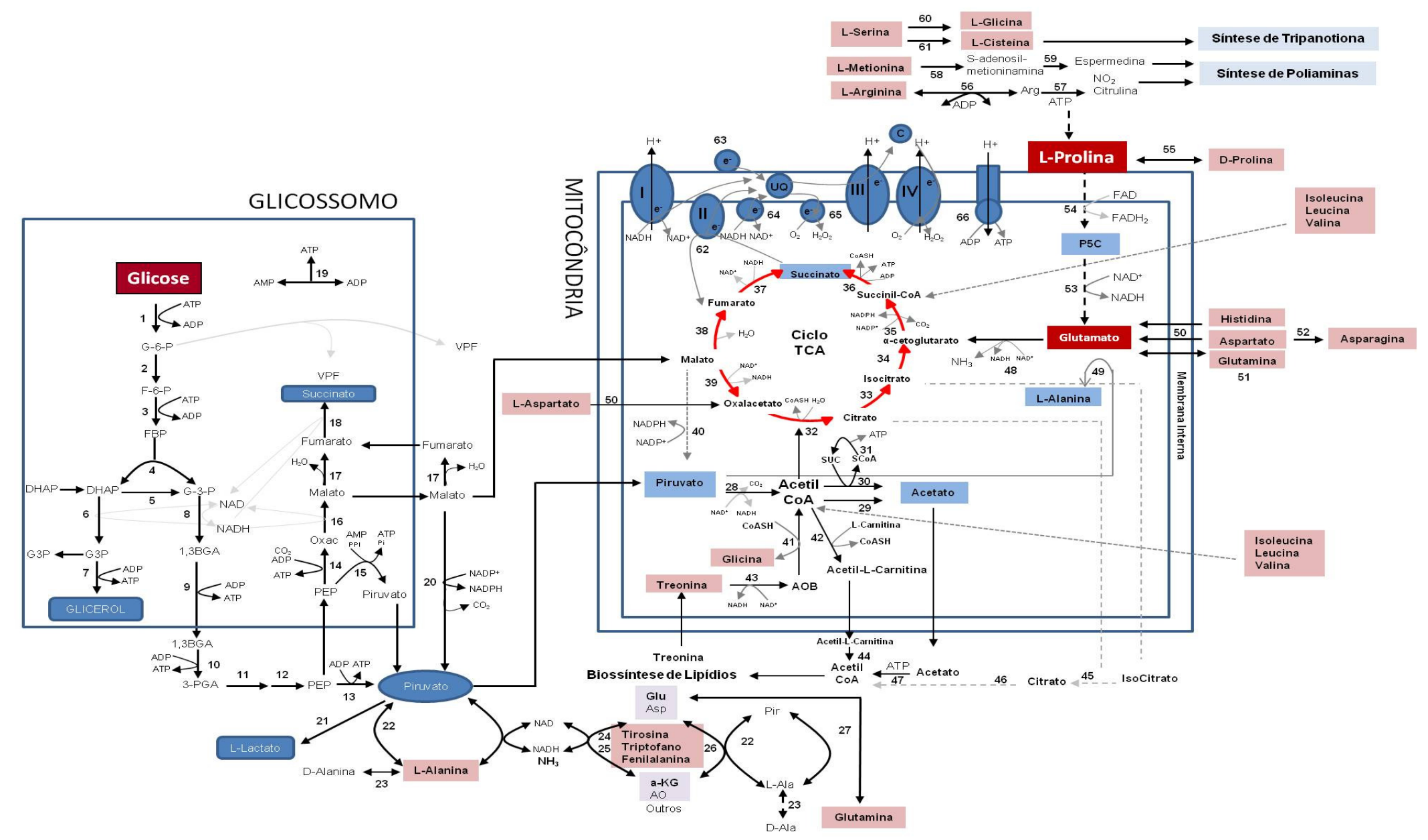

Figura 2. Representação esquemática do metabolismo de fontes de carbono e aminoácidos em $\boldsymbol{T}$. cruzi. As Linhas sólidas representam vias ou reações que já foram bioquimicamente demonstradas. As linhas pontilhadas representam vias ou reações putativas inferidas do a partir de genes identificados no projeto genoma de $T$. cruzi. Os produtos finais excretados a partir do metabolismo de glicose e aminoácidos (acetato, L-alanina, glicerol, L-glicina, L-lactato, succinato e $\mathrm{CO}_{2}$ ) estão destacados em azul. Nos compartimentos mitocondrial e glicossomal, estão representados o ciclo do ácido cítrico (TCA), via das pentoses fosfato (VPF), a via da biossíntese de lipídios e a cadeia transportadora de elétrons. Abreviações: AOB- amino oxibutirato, 1,3-BGA- bisfosfoglicerato, C- citocromo c, CoASHcoenzima A, DHAP- fosfato dihidroxiacetona, F-6-P- frutose 6-fosfato, FBP-frutose 1,6-bisfosfato, G-3-P-gliceraldeído 3-fosfato, G-6-P-glicose 6-fosfato, $\alpha$ KG- $\alpha$ cetoglutarato, AO- ácido oxaloácetico, PEP-fosfoenolpiruvato, 3-PGA -3-fosfoglicerato, Pi-fosfato inorgânico, Pii-pirofosfato inorgânico, SucCoAsuccinil-CoA, UQ-ubiquinona.Os números correspondem as enzimas descritas no quadro a seguir.

Fonte: Modificado de Bringaud et al. (2006) e Silber et al. (2005). 


\begin{tabular}{|c|c|}
\hline ENZIMAS & ENZIMAS \\
\hline 1-hexoquinase & 35- complexo2-cetoglutarato desidrogenase \\
\hline 2-glicose-6-fosfato isomerase & 36- succinil CoA-sintetase \\
\hline 3-fosfofrutoquinase & $\begin{array}{l}\text { 37-fumarato redutase NADH-dependente } \\
\text { mitocondrial }\end{array}$ \\
\hline 4-aldose & 38- fumarase mitocondrial \\
\hline 5-triose-fosfato-isomerase & 39- malato desidrogenase mitocondrial \\
\hline 6-glicerol-3-fosfato desidrogenase & 40- enzima málica mitocondrial \\
\hline 7- glicerol quinase & 41-acetil-CoA:glicina CoA acetiltransferase \\
\hline 8-gliceraldeído-3-fosfato desidrogenase & 42- aceti-L-carnitina transferase \\
\hline 9-fosfoglicerato quinase glicosssomal & 43- L-treonina desidrogenase \\
\hline 10- fosfoglicerato quinase citosólica & 44- acetil L-carnitina transferase \\
\hline 11- fosfoglicerato mutase & 45- aconitase, \\
\hline 12- enolase & 46- citrato liase \\
\hline 13- piruvato quinase & 47- acetil CoA sintetase \\
\hline 14- fosfoenolpiruvato carboxiquinase & 48- glutamato desidrogenase \\
\hline 15- piruvato fosfato diquinase & 49- alanina aminotransferase \\
\hline 16- malato desidrogenase glicossomal & 50- aspartato aminotransferase \\
\hline 17-fumarase citosólica (e glicossomal) & 51- glutamina sintetase e glutamina deaminase \\
\hline $\begin{array}{l}\text { 18-fumarato redutase NADH-dependente } \\
\text { glicossomal }\end{array}$ & 52- asparagina sintetase \\
\hline 19- adenilato quinase glicossomal & 53- $\Delta$-pirrolina-5-carboxilato desidrogenase \\
\hline 20- enzima málica citosólica & 54- prolina desidrogenase \\
\hline 21- enzima desconhecida & 55- prolina racemase \\
\hline 22- alanina aminotransferase & 56- arginina quinase \\
\hline 23- alanina racemase & 57- óxido nítrico sintase \\
\hline 24- tirosina aminotransferase & 58- metionina adenosiltransferase \\
\hline 25- glutamato desidrogenase & 59- espermidina sintase \\
\hline 26- aspartato aminotransferase & 60- serina hidroximetiltransferase \\
\hline 27-glutamina sintetase & 61- cistationina $\beta$-sintase \\
\hline 28- complexo piruvato desidrogenase & 62- succinato desidrogenase \\
\hline 29- enzima desconhecida & 63- glicerol 3-fosfato desidrogenase (FAD) \\
\hline 30- acetato succinato CoA-transferase & 64- NADH desidrogenase (insensível a rotenona) \\
\hline 31- succinil CoA-sintetase & 65- oxidases alternativas \\
\hline 32- citrato sintase & 66- $\mathrm{F}_{0} \mathrm{~F}_{1}-\mathrm{ATP}$ sintase \\
\hline \multicolumn{2}{|l|}{ 33- aconitase } \\
\hline 34- isocitrato desidrogenase & \\
\hline
\end{tabular}

Figura 3. Quadro com a descrição das enzimas presentes na representação esquemática do metabolismo de fontes de carbono e aminoácidos em $T$. cruzi. 


\subsection{Via das pentoses fosfatos (VPF)}

A VPF é uma rota alternativa de oxidação da glicose e compreende um processo de descarboxilação oxidativa que converte a glicose-6-fosfato em ribose 5-fosfato, $\mathrm{CO}_{2} \mathrm{e}$ NADPH. A ribose 5-fosfato (pentose) é convertida a 5-ribosil-1-pirofosfato que seguirá para a síntese das bases nitrogenadas purínicas e pirimidínicas (ácidos nucléicos). A energia gerada neste processo é armazenada sob a a forma de poder redutor (NADPH) e não como ATP, como acontece na glicólise. O NADPH, por sua vez, doa elétrons para a biossíntese de ácidos graxos e esteróides, além de exercer um papel importante na proteção celular contra o estresse oxidativo imposto por EROs (BARRETT, 1997; MAUGERI; CAZZULO, 2004; IGOILLO-ESTEVE et al., 2007). Neste sistema atua a tripanotiona de $T$. cruzi, que é mantida no estado reduzido pela tripanotiona redutase, a qual utiliza NADPH como cofator (TRUJILLO et al., 2004).

As enzimas que constituem a VPF estão distribuídas no glicossomo e citossol em todos os estágios do ciclo de via do T. cruzi. Embora a regulação dessa via em $T$. cruzi não seja bem conhecida, sabe-se que na maioria dos organismos eucarióticos, o fornecimento de glicose-6-fosfato pela VPF depende da relação ATP/ADP e NADPH/NADP para ajustar o funcionamento desta via e as necessidades energéticas das células. É possivel que isso também ocorra neste parasito (MAUGERI; CAZZULO, 2004) (Figura 2 e Figura 3).

\subsection{Acetil -CoA}

O catabolismo das principais fontes de carbono em tripanossomatídeos (Dglicose, L-prolina, L-glutamato, L-aspartato, L-treonina dentre outros) resulta na formação de acetato. Em formas procíclicas de T. brucei, a maior parte do piruvato produzido pela glicólise é descarboxilada a acetil-CoA pelo complexo da piruvato desidrogenase (PDH) na mitocôndria (BRINGAUD; RIVIERE; COUSTOU, 2006).

Até pouco tempo atrás, considerava-se que na maioria dos tripanossomatídeos, o acetil-CoA produzido pelo metabolismo da glicose, seria convertido em acetato e também a $\mathrm{CO}_{2}$, atráves do Ciclo de Krebs. No entanto, estudos recentes concluiram que a maior parte do acetil-CoA produzido a partir da glicólise (se não todo) é convertido em acetato excretado (VAN HELLEMOND; OPPERDOES; TIELENS, 2005; VAN WEELDEN et al., 2005). A produção de acetato envolve dois passos, i) a enzima succinato CoAtransferase (ASCT) transfere a CoA do acetil-CoA ao succinato rendendo acetato e succinil-CoA, ii) este último é subseqüentemente reconvertido em succinato pela enzima 
succinil-CoA sintetase (SCoAS) com concomitante produção de ATP (VAN HELLEMOND; OPPERDOES; TIELENS, 1998).

O acetil-CoA é um metabólito intermediário chave entre o catabolismo e anabolismo de carboidratos, aminoácidos e ácidos graxos. Por exemplo, em procíclicos de T. brucei, foi mostrado que o acetil-CoA produzido a partir de glicose e L-treonina é substratos para a biossíntese de lipídios. Como a síntese de ácidos graxos ocorre no citoplasma e o processo de produção de acetil-CoA na mitocôndria, este deve ser transferido para o citoplasma (VAN WEELDEN et al., 2005). A interconversão a citrato é usada por todos os eucariotos para que o grupo acetil da matriz mitocondrial possa cruzar a membrana interna mitocondrial em direção ao citosol. $O$ acetil-CoA intramitocondrial primeiro reage com oxalacetato para formar citrato, reação que ocorre no ciclo de Krebs catalizada pela enzima citrato sintase. O citrato passa através da membrana interna mitocondrial pelo transportador de citrato ou pelo trocador citrato/malato, onde no citosol é convertido de volta a acetil-CoA e oxalacetato pela enzima citrato liase citosólica (BRINGAUD; EBIKEME; BOSHART, 2009).

Van Weelden et al. (2002) sugeriram que o acetil-CoA dos tripanossomas também pode mudar entre esses compartimentos (mitocôndria e citoplasma) via interconversão a citrato/malato, através de reações das enzimas citrato sintase e liase. Porém, Riviere et al. (2009) relatam que, ao contrário de outros eucariotos, os tripanossomas não usam a mudança citrato/malato para a síntese de lipídios, já que uma das enzimas chave dessa reação, a citrato liase, está ausente (pelo menos no estágio procíclico de $T$. brucei). Embora o genoma dos tripanossomatídeos possua genes putativos codificadores da citrato-sintase e citrato-liase (VAN WEELDEN et al., 2005), o gene para a citrato liase foi reportado em tripanossotídeos com base em uma sequência com baixa similaridade (RIVIERE et al., 2009).

Dados experimentais sugerem a existência de outros possíveis sistemas de trocas que alimentam as vias anabólicas e a biossíntese de lipídios em tripanossomas. São exemplos, o sistema L-carnitina acil-transferase (CAT), que pode trocar o grupo acetil do acetato pelo grupo acil, e a enzima acetil-CoA sintetase citosólica, que pode converter o acetato em acetil-CoA (GILBERT; KLEIN, 1982, 1984). Os tripanossomatídeos também podem utilizar essas vias alternativas, haja visto que $T$. brucei possui altos níveis de atividade da enzima L-carnitina acetiltransferase, a qual é descrita como um passo chave na biossíntese de lipídeos a partir do acetil-CoA derivado de L-treonina. Além disso, os 
tripanossomatídeos produzem quantidades consideráveis de acetato, o qual se difunde através das membranas e pode ser convertido em acetil-CoA pela acetil-CoA sintetase citosólica putativa (KLEIN; ANGUS; WATERHOUSE et al., 1982; BRINGAUD; EBIKEME; BOSHART, 2009).

Todavia, mais evidências experimentais são necessárias para entender o modo de exportar o acetato da mitocôndria para o citosol para ser utilizado na biossíntese de lipídios em tripanossomas (BRINGAUD; RIVIERE; COUSTOU, 2006), já que não foi identificado um transportador putativo monocarboxílico mitocondrial ou genes de troca de citrato no genoma de T. brucei (COLASANTE et al., 2009).

\subsection{Produção de ATP}

Durante muitos anos considerou-se que a maioria dos tripanossomatídeos, que cresciam em meio rico em glicose, produziam ATP primariamente pela ATP sintase mitocondrial $\mathrm{F}_{0} / \mathrm{F}_{1}$ (fosforilação oxidativa), explorando o gradiente de prótons entre ambos os lados da membrana mitocondrial interna gerado através da cadeia respiratória. No entanto, estudos recentes questionaram estas conclusões e um novo modelo foi proposto (BESTEIRO et al., 2005; COUSTOU et al., 2008).

Em experimentos realizados, expondo formas procíclicas de T. brucei a um excesso de oligomicina (inibidor específico da $\mathrm{F}_{0} / \mathrm{F}_{1}$ ATP sintase), não foi observada alteração significativa nas concentrações intracelulares de ATP e nem na viabilidade dos parasitos crescidos em meio rico em glicose. No entanto, quando os parasitos foram cultivados em meio pobre em glicose, tornam-se 1000 vezes mais sensíveis à oligomicina. Isto suporta a idéia de que, na presença de glicose, as formas procíclicas não são dependentes da fosforilação oxidativa para a produção de ATP, e que a maior parte do ATP é produzido por fosforilação a nível do substrato, atráves das enzimas chave, tais como a fosfoglicerato quinase (PGK), piruvato quinase (PK) e succinil CoA sintase mitocondrial (SCS). Já na ausência de glicose, quando as células desviam seu metabolismo para o catabolismo de aminoácidos, a fosforilação oxidativa torna-se essencial (LAMOUR et al., 2005).

As evidências experimentais recentes também mostraram que, considerando a taxa de consumo de glicose e/ou prolina e o número de moléculas de ATP produzidas e consumidas, estima-se que a produção de ATP pela fosforilação a nível do substrato é pelo menos três vezes maior em meio rico em glicose do que em meio pobre em glicose. Isto indica que a ATP sintase mitocondrial $\left(\mathrm{F}_{0} / \mathrm{F}_{1}\right)$ possui um papel menos relevante na 
produção de energia, e que a maior parte do ATP é produzido por fosforilação a nível do substrato (BARRETT et al., 2003; COUSTOU et al., 2003; BESTEIRO et al., 2005).

As células eucarióticas desenvolveram vários mecanismos de controle da fosforilação oxidativa, incluindo a sua regulação pela disponibilidade de substratos tal como o oxigênio, ADP e equivalentes redutores. O grau de acoplamento entre a respiração e a fosforilação oxidativa também é controlado. Dois processos regulatórios distintos foram descritos em eucariotos: I) um sistema de dissipação do potencial eletroquímico de prótons, representado por proteínas desacopladoras e II) um sistema de dissipação do potencial redox, representados por oxidases alternativas (BROWN, 1992). Em tripanossomatídeos somente o sistema II tem sido descrito. Neste caso, o fluxo de elétrons do ubiquinol (Coenzima Q) para a via oxidase alternativa de tripanossomas (TAO) não está acoplada à produção de ATP, enquanto que a transferência de elétrons mediada por citocromos (complexos III e IV) está acoplada à produção de ATP, através da geração de um gradiente de prótons. Este sistema duplo pode fornecer grande flexibilidade para modular a geração de um gradiente de prótons e, assim, regular a fosforilação oxidativa (BESTEIRO et al., 2005; BRINGAUD; RIVIERE; COUSTOU, 2006).

\subsection{Metabolismo dos aminoácidos em tripanossomatídeos}

Como já discutido, os tripanosomatídeos são capazes de utilizar carboidratos e aminoácidos como fontes de carbono e energia. Os epimastigotas catabolizam preferencialmente glicose, e depois da exaustão desse metabólito, ocorre o catabolismo de proteínas e aminoácidos com produção de amônia (CALDAS et al., 1980; CAZZULO, 1992, 1994). Os aminoácidos podem ser obtidos por transporte, biossíntese a partir de precursores metabólicos e/ou pela degradação de proteínas (CAZZULO, 1984).

Trabalhos clássicos mostraram que asparagina, glutamina, aspartato, glutamato, leucina, isoleucina e prolina são metabolizados pelo T. cruzi (ZELEDON, 1960; MANCILLA; NAQUIRA; LANAS， 1967; SYLVESTER; KRASSNER， 1976; CAZZULO, 1992). Todos esses aminoácidos podem ser convertidos em glutamato ou aspartato, os quais por sua vez são transportados do citoplasma para a mitocôndria e consequentemente processados via Ciclo de Krebs (SILBER et al., 2005). Como mencionado anteriormente, o consumo de proteínas e aminoácidos como substratos oxidáveis em cultura de epimastigotas de $T$. cruzi exige a eliminação de $-\mathrm{NH}_{2}$, cujo excesso pode ser liberado no meio extracelular como $\mathrm{NH}_{3}$. 
$\mathrm{O}$ eventual acúmulo de $\mathrm{NH}_{3}$ não pode ser resolvido através do ciclo da uréia, já que faltam várias das enzimas nele envolvidas (Camargo et al., 1978; YOSHIDA; CAMARGO, 1978). Porém, o parasito possui um sistema enzimático de transferência de $-\mathrm{NH}_{2}$ entre diferentes espécies químicas, constituído por desidrogenases e transaminases (ou aminotransferases) (NOWICKI et al., 1992). As desidrogenases têm várias funções, permitindo, dentre outras coisas, a detoxificação de $\mathrm{NH}_{3}$ mediante a sua transferência para cetoácidos como o $\alpha$-cetoglutarato, transformando-o em glutamato (Barderi et al., 1998). Por sua vez, as transaminases são responsáveis pela transferência de grupos $-\mathrm{NH}_{2}$ de quase todos os aminoácidos para o piruvato produzindo alanina e liberando os cetoácidos correspondentes (por exemplo, regenerando $\alpha$-cetoglutarato) para serem oxidados ou reciclados como intermediários do Ciclo de Krebs. Este sistema contribui para evitar o acúmulo de $\mathrm{NH}_{3}$, produzindo em seu lugar um acúmulo de alanina, bem menos tóxica (CAZZULO, 1984, 1992, 1994; SILBER et al., 2005).

As aminotransferases mais relevantes descritas até o momento são: a aspartato aminotransferas, a alanina aminotransferase (ALAT), a tirosina aminotransferase (TAT) e a aminotransferase de aminoácidos aromáticos, L- $\alpha$-hidroxiácido desidrogenase (AHADH). Todas elas estão presentes em dois compartimentos subcelulares, no citosol e na matriz mitocondrial (NOWICKI et al., 1992; MONTEMARTINI et al., 1995; CAZZULO FRANKE et al., 1999; MARCIANO et al., 2008; NOWICKI; CAZZULO, 2008; MARCIANO et al., 2009).

O grupo $-\mathrm{NH}_{2}$ do glutamato pode ser transferido para o piruvato pela ALAT, e até certo ponto, pela TAT, produzindo $\alpha$-cetoglutarato e alanina, e também pode ser transferido para $\mathrm{H}_{2} \mathrm{O}$ pela glutamato desidrogenase. Em T. cruzi, foram descritas duas isoformas dessa enzima, uma dependente de $\mathrm{NADP}^{+}$(citosólica) (BARDERI et al., 1998) e outra de $\mathrm{NAD}^{+}$(mitocondrial) (URBINA; CRESPO, 1984). Ambas participam também na biossíntese de aminoácidos através da sua habilidade de incorporar $\mathrm{NH}_{3}$ em $\alpha$ cetoglutarato produzindo glutamato. $\mathrm{O}$ efeito combinado das transaminases e da glutamato desidrogenase substitui a necessidade de desidrogenases individuais para todos os aminoácidos (DUSCHAK; CAZZULO, 1991; NOWICKI; CAZZULO, 2008).

O papel da arginina na biologia do $T$. cruzi foi estudado com bastante detalhe. Pereira et al. (1999) demonstraram que este aminoácido está envolvido na produção de energia da célula através de uma arginina quinase (enzima que catalisa a interconversão entre fosfoarginina e ATP). A arginina quinase catalisa a interconversão reversível entre 
arginina e fosfoarginina mediante gasto ou ganho de ATP (dependendo do sentido da reação). Foi mostrado que essa atividade está relacionada com a taxa de crescimento do parasito (PEREIRA et al., 2002) e com a resistência a estresses de pH, nutricional e oxidativo (PEREIRA et al., 2002, 2003). Outros autores também mostraram a relação entre arginina e a síntese de óxido nítrico e poliaminas (PELUFFO et al., 2004).

Um fator de estresse importante que envolve vários aminoácidos na biologia dos tripanosomos é o estresse osmótico. Alguns trabalhos relataram que o fluxo de vários aminoácidos (dentre eles glutamato, glicina, prolina e alanina) entre o acidocalcissomo e o citoplasma contribui para a regulação do volume celular. Esse processo seria parte do mecanismo de resistência ao estresse osmótico a que o parasito é submetido durante as mudanças de ambientes que sofre ao longo do seu ciclo de vida (ROHLOFF; DOCAMPO, 2008).

A prolina em particular, atua como um importante osmoprotetor, participando da resposta ao estresse osmótico quando o T. cruzi circula em diferentes ambientes como o tubo digestivo do inseto, o sangue do hospedeiro mamífero ou o citoplasma da célula hospedeira. Por sua vez, tanto a prolina quanto o aspartato e o glutamato promovem a diferenciação das formas epimastigotas de $T$. cruzi para formas tripomastigotas metacíclicas (metaciclogênese) no inseto vetor (CONTRERAS et al., 1985; HOMSY et al., 1989) e de epimastigotas intracelulares para tripomastigota, processo que acontece no citoplasma das células infectadas (TONELLI et al., 2004)

Em T. cruzi também foi identificada uma enzima com atividade serina acetiltransferase que pode converter L-serina em L-cisteína (NOZAKI et al., 2001), além disso, estudos recentes demonstraram que L-cisteína também é ativamente transportada em epimastigotas de T. cruzi (CANEPA et al., 2009). Nos tripanossomatídeos, a Lcisteína é particularmente relevante como substrato na síntese de glutationa e tripanotiona (WILKINSON et al., 2002). Desta forma, os aminoácidos apresentam, nos tripanossomatídeos, uma surpreendente diversidade de funcões (SILBER et al., 2005). 


\subsection{O Ciclo da L-Prolina}

Houve grande confusão na literatura em relação à nomenclatura da primeira enzima envolvida no catabolismo de prolina. Contudo, recentemente foi alcançado um consenso por vários laboratórios no $2^{\circ}$ Simpósio Internacional do metabolismo de prolina na Saúde e na doença, realizado em setembro de 2007, em que ficou definido que a primeira enzima da via degradativa da prolina seria designada prolina desidrogenase (PRODH) ou prolina oxidase (POX). Alguns autores ainda usam a nomenclatura abreviada (PRODH/POX), o que também é considerado aceitável. O gene, contudo, poderia ser referido como PRODH (PHANG et al., 2008). Desta forma, referiremos a esta enzima neste trabalho, como PRODH.

$\mathrm{Na}$ maioria dos organismos, a prolina é catabolizada a glutamato (e posteriormente a intermediários do ciclo de Krebs) atravésde dois passos enzimáticos acoplados a uma reação não enzimática que ocorre na mitocôndria. O primeiro passo dessa conversão é a oxidação da L-prolina à $\Delta^{1}$-pirrolina-5-carboxilato (P5C) pela enzima FAD dependente, prolina desidrogenase (PRODH/ PO) (EC: 1.5.99.8). A P5C é uma molécula que (no ambiente mitocondrial) se interconverte espontaneamente em glutamato semi-aldeído (GSA), existindo ambas as espécies no estado de equilíbrio desta reação não enzimática. No segundo passo da reação, a enzima $\Delta^{1}$-pirrolina-5-carboxilato desidrogenase (P5CDH) (EC: 1.5.1.12), $\mathrm{NAD}^{+}$dependente, completa a conversão da prolina a glutamato pela catálise da oxidação de GSA (HOEK; NJOGU, 1980; PHANG; YEH; HAGEDORN, 1981)

As enzimas envolvidas no metabolismo da prolina têm sido descritas e caracterizadas em diferentes organismos desde 1936 (DAS, 1936; ADAMS; FRANK, 1980). Desde então, os cofatores utilizados pelas principais enzimas envolvidas no catabolismo de prolina, a PRODH e a P5CDH vem sendo demonstrado. A enzima PRODH é considerada uma enzima dependente de FAD na maioria dos organismos (PHANG, 1985; TSUGE et al., 2005; WHITE et al., 2007). No entanto, alguns trabalhos têm reportado a PRODH como uma enzima dependente de $\mathrm{NAD}^{+}$(RENA; SPLITSTOESSER, 1974; GUERRIER et al., 1998).

Em algumas bactérias, a enzima PRODH aparece fusionada com a P5CDH numa única proteína, denominada Put A. Por se tratar de uma enzima bifuncional, a PutA utiliza tanto FAD quanto NAD ${ }^{+}$com cofatores (MENZEL; ROTH, 1981; ZHANG et al., 2004; WHITE et al., 2007). Considerando essas particularidades existentes em diferentes 
organismos, seria importante, ao estudar o metabolismo de prolina, a definição do uso dos cofatores por parte das enzimas envolvidas nesta via.

A biossíntese de prolina tem duas rotas de formação. A primeira envolve dois passos enzimáticos catalisados pela $\gamma$-glutamil quinase ( $\gamma$-GK) (EC: 2.7.2.11) e $\gamma$-glutamil fosfato redutase $(\gamma-G P R)$ (EC: 1.2.1.41). Estas enzimas são fusionadas em plantas e animais e formam uma enzima bifuncional chamada $\Delta^{1}$-pirrolina-5-carboxilato sintetase (P5CS), porém, em bactérias e leveduras são proteínas separadas. A $\gamma$-GK catalisa a transferência do grupo fosforil do ATP para o glutamato formando $\gamma$-glutamil fosfato que por sua vez, é reduzido a glutamato semi-aldeído (GSA) pela enzima $\gamma$-GPR, sendo esta redução dependente de NADPH. A outra rota parte da ornitina para GSA e é catalisada pela enzima ornitina aminotransferase (OAT, EC: 2.6.1.13), uma enzima dependente de piridoxal-5 -fosfato. Como mencionado anteriormente, o GSA e o P5C são espécies químicas que se interconvertem espontaneamente nas condições do ambiente intramitocondrial, o que fornece P5C como substrato para ser reduzido a prolina pela $\Delta^{1}$ pirrolina-5-carboxilato redutase (P5CR), enzima que usa NADPH como doador de elétrons (PHANG et al., 2008; TANNER, 2008) (Figura 4). 


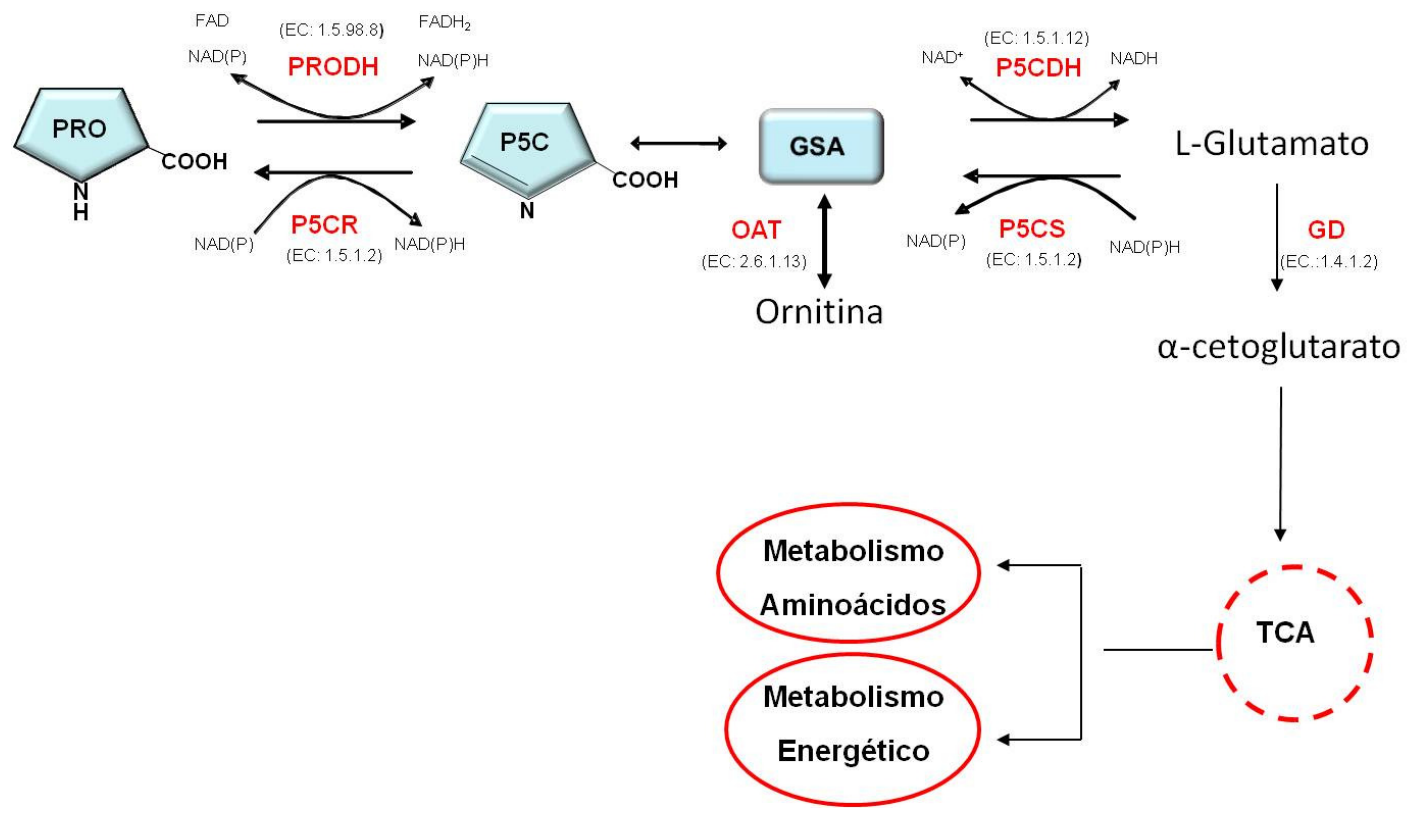

Figura 4. Representação esquemática do metabolismo de L-prolina. O primeiro passo na degradação da prolina (PRO) é a sua conversão a pirrolina-5-carboxilato (P5C) pela prolina desidrogenase (PRODH). Em seguida, P5C pode ser convertida espontaneamente a glutamato semialdeído (GSA), o qual é reduzido de volta a prolina pela enzima pirrolina-5-redutase (P5CR) ou ainda ser convertida a glutamato pela pirrolina-5-desidrogenase (P5CDH). Posteriormente, o glutamato é desaminado gerando $\alpha$-cetoglutarato pela glutamato desidrogenase (GD). $\mathrm{O} \alpha$-cetoglutarato por sua vez, entra no ciclo de Krebs, e assim participa dos metabolismos energético e de aminoácidos. Alternativamente, a P5C-GSA pode ser convertida a ornitina pela ornitina aminotransferase (OAT) e participar das reações do ciclo da uréia. 
Como mencionado anteriormente, a L-prolina é um metabólito relevante para os tripanossomatídeos e pode ser usado como principal fonte de carbono e energia (CAZZULO, 1994). De fato, Sylvester e Krassner (1976) demonstraram que a L-prolina pode ser oxidada e metabolizada através do Ciclo de Krebs, o que aconteceria mediante a sua conversão em glutamato (SILBER et al., 2005). Recentemente, foi mostrado que $T$. cruzi pode importar a prolina do meio extracelular, o que acontece através de dois sistemas de transporte ativo: um de alta afinidade (sistema A) e outro de baixa afinidade (sistema B) (SILBER et al., 2002). A atividade desses transportadores, que foram caracterizados bioquímicamente, está relacionada à replicação das formas epimastigotas intracelulares do parasito e a sua diferenciação para formas infectivas (TONELLI et al., 2004). Em L. donovani, a atividade do transporte de L-prolina e regulada por $\mathrm{pH} \mathrm{e}$ temperatura, e este transporte parece estar relacionado com processos de diferenciação celular e metabolismo energético (ZILBERSTEIN; GEPSTEIN, 1993; ZILBERSTEIN; SHAPIRA, 1994; MAZAREB; FU; ZILBERSTEIN, 1999)

Uma vez dentro da célula, a L-prolina pode ser substrato de várias enzimas metabólicas. Uma delas é a enzima prolina racemase (REINA-SAN-MARTIN et al., 2000) que foi posteriormente caracterizada em detalhe (CHAMOND et al., 2003) e parece estar envolvida na infecção e diferenciação de T. cruzi (CHAMOND et al., 2005). Trabalhos recentes mostraram ainda que o uso de um inibidor específico desta enzima reduziu a infecção in vitro do parasito em células Vero (COUTINHO et al., 2009). Em T. brucei o gene que codifica a prolina desidrogenase (PRODH), primeira enzima envolvida no catabolismo da prolina, foi clonado e estudos de interferência por RNA (RNAi) revelaram que a perda da atividade dessa enzima é letal em T. brucei (LAMOUR et al., 2005).

Apesar da sua reconhecida importância, pouco se sabe sobre o metabolismo da prolina em T. cruzi. Porém, fatos como, o processamento da prolina através do Ciclo de Krebs (SYLVESTER; KRASSNER, 1976), a presença de pelo menos dois transportadores para prolina e um para glutamato (SILBER et al., 2002; SILBER et al., 2006) e a existência de genes que codificam para as enzimas dessa via no banco de dados do genoma de $T$. cruzi (dentre estes para as enzimas putativas PRODH (números sistemáticos Tc00.1047053511237.30 e Tc00.1047053506411.30 [www.genedb.org]) e P5CDH (números sistemáticos Tc00.1047053509351.10, Tc00.1047053510943.50 e Tc00.1047053503577.9) dão suporte à existência desse passo metabólico nesse parasito 
(SILBER et al., 2005). Em função dos estudos realizados previamente e das informações publicadas na literatura, sobretudo a respeito do importante papel da L-prolina no metabolismo energético (CAZZULO, 1994) diferenciação celular (CONTRERAS et al., 1985; TONELLI et al., 2004) e osmorregulação (ROHLOFF; RODRIGUES; DOCAMPO, 2003) em T. cruzi, propomos a caracterização da primeira enzima envolvida no catabolismo da prolina, a prolina desidrogenase, e a análise de suas perspectivas como possível alvo terapêutico. 


\section{OBJETIVOS}

\subsection{Objetivo geral}

$\checkmark$ Caracterizar a enzima prolina desidrogenase (PRODH) do ponto de vista bioquímico, molecular e determinar seu papel funcional na biologia do parasito;

\subsection{Objetivos específicos}

$\checkmark$ Identificar e caracterizar o gene putativo da PRODH de T. cruzi;

$\checkmark$ Avaliar a funcionalidade do produto codificado pelo gene putativo da PRODH;

$\checkmark$ Caracterizar a PRODH do ponto de vista cinético;

$\checkmark$ Avaliar os requerimentos para a atividade da PRODH, assim como o efeito de eventuais fatores regulatórios;

$\checkmark$ Determinar os níveis transcricionais e proteícos da PRODH nos diferentes estágios de vida de T. cruzi;

$\checkmark$ Estudar um possível papel biológico da prolina e da PRODH em condições de estresse oxidativo;

$\checkmark$ Avaliar o efeito de análogos estruturais da prolina sobre a atividade da PRODH de T. cruzi e também sobre a biologia do parasito;

$\checkmark$ Investigar o papel da PRODH na cadeia respiratória do T. cruzi. 


\section{MATERIAIS E MÉTODOS}

\subsection{Microorganismos, plasmídeos e oligonucleotídeos utilizados no trabalho}

a) Trypanosoma cruzi

- Cepa CL, clone 14 (BRENER; CHIARI, 1963)

\section{b) Célula hospedeira}

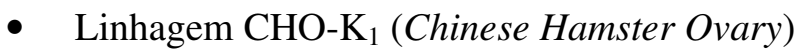

\section{c) Escherichia coli}

\begin{tabular}{|c|c|c|}
\hline Linhagem & Genótipo & Referência/Origem \\
\hline $\mathrm{DH} 5 \alpha$ & $\begin{array}{l}\sup E, \Delta l a c U 169, \phi 80 l a c Z \Delta M 15, \text { hsdR17, recA1, endA1, } \\
\text { gyrA96, thi-1, relA1, F'[traD36, proAB, laclq, lacZ } \Delta M 15]\end{array}$ & Hanahan, D., 1983 \\
\hline BL21-Codon Plus (DE3)-RIL & F- ompT hsdSB(rB- mB- gal dcm $\lambda(\mathrm{DE} 3)$ pLysS $\left(\mathrm{Cm}^{\mathrm{R}}\right)$ & Stratagene \\
\hline
\end{tabular}

Figura 5. Quadro das células de bactérias utilizadas no trabalho

\section{d) Saccharomyces cerevisiae}

\begin{tabular}{|c|c|c|}
\hline Linhagem & Genótipo & Referência/Origem \\
\hline BY4741 & $\begin{array}{c}\text { MATa his } 3 \Delta 1 \text { leu2 } 2 \Delta 0 \text { met } 15 \Delta 0 \text { ura } 3 \Delta 0 \\
\text { Selvagem (WT) }\end{array}$ & EUROSCARF \\
\hline YLR142w & $\begin{array}{c}\text { MATahis3 } \Delta \text { 1;leu2 } \Delta 0 \text {;met15 } \Delta 0 \text {; ura3 } \Delta 0 \text { / YLR142w::kanMX4 (PUT1 } \Delta \text { ) } \\
\text { Mutante para o gene PRODH }\end{array}$ & EUROSCARF \\
\hline YLR142W/pYES2 & $\begin{array}{c}\text { MATahis3 } \Delta 1 ; \text { leu2 } \Delta 0 \text {;met15 } \Delta 0 \text {; ura3 } \Delta 0 / \text { YLR142w::kanMX4 (PUT1 } \Delta \text { ) } \\
\text { Mutante para o gene PRODH } \\
\text { transformada somente com o vetor pYES } 2 \text { (Controle) }\end{array}$ & Presente Trabalho \\
\hline YLR142w/PODH & $\begin{array}{c}\text { MATahis } 3 \Delta 1 \text {;leu2 } \Delta 0 \text {;met15 } \Delta 0 ; \text { ura3 } \Delta 0 / \text { YLR142w::kanMX4 (PUT1 } \Delta) \\
\text { Mutante para o gene de PRODH complementada } \\
\text { com a construção pYES /PRODH de } \text {.cruzi }\end{array}$ & Presente Trabalho \\
\hline
\end{tabular}

Figura 6. Quadro das leveduras utilizadas no trabalho 
e) Plasmídeos e construções

\begin{tabular}{|c|c|c|}
\hline Linhagem & Características & Referência/Origem \\
\hline pGEM-T-easy & pUC Ori, gene de fusão LacZa-ccdB, AMPR & Promega \\
\hline pYES 2.0 & CYC1, pUC Ori, promotor GAL1, URA3, AMPR & Invitrogen \\
\hline$p A E$ & His-tag N-terminal, T7-tag N-terminal, AMPR & Ramos et al., 2004 \\
\hline PRODH & $\begin{array}{r}\text { Seqüência codificadora do gene PRODH de T.cruzi } \\
\text { clonadano pGEM-T-easy e subclonada nos vetores } \\
\text { pAE sítios e } p Y E S \text { sítios }\end{array}$ & Presente Trabalho \\
\hline
\end{tabular}

Figura 7. Quadro dos vetores e gene utilizados no trabalho

\section{f) Oligonucleotídeos}

\begin{tabular}{|c|c|}
\hline Oligonucleotídeo & Descrição \\
\hline PRODH & F 5'- TTAGGATCCTCTCCAACTTCACGCAAAATTC-3' \\
\hline PRODH & R 5'- GAATTCCTAAGCCTTTACATCTTTTTCCCG- 3' \\
\hline PRODH Real Time & F 5'- ACGCAAAATTCAGCCGGTAA-3' \\
\hline PRODH Real Time & R5'-GGCTCGCACTAACCACCAAA-3' \\
\hline GAPDH Real Time & F 5'- GTGGCAGCACCGGTAACG -3' \\
\hline GAPDH Real Time & R5'- CAGGTCTTTCTTTTGCGAATAGG-3' \\
\hline M13 & F 5'-GTAAAACGACGGCCAG-3' \\
\hline M13 & R5'-CGGATAACGCTTGCGACCTATG-3' \\
\hline F 5'-TAATACGACTCACTATAGG-3'
\end{tabular}

Figura 8. Quadro dos oligonucleotídeos utilizados no trabalho 


\subsection{Obtenção de parasitas}

As formas epimastigotas extracelulares de T. cruzi, cepa CL, clone 14 (BRENER; CHIARI, 1963) foram mantidas em fase exponencial de crescimento em meio LIT (Liver Infusion-Tryptose) pH 7,2, que contém infusão de fígado 5,0 g/L, Triptose 5,0 g/L, NaCl 4,0 g/L, KCL 0,4 g/L, $\mathrm{Na}_{2} \mathrm{HPO}_{4}$ 8,0 g/L, glicose $2 \mathrm{~g} / \mathrm{L}$, hemina $10 \mathrm{~g} / \mathrm{L}$ suplementado com $10 \%$ de soro fetal bovino (SFB) a $28^{\circ} \mathrm{C}$ (CAMARGO, 1964).

\subsubsection{Células hospedeiras}

Células da linhagem $\mathrm{CHO}-\mathrm{K}_{1}$ foram cultivadas a $37{ }^{\circ} \mathrm{C}$ em meio RPMI 1640 (Cultilab) acrescido com $10 \%$ de SFB (Cultilab), 0,15\% (m/v) $\mathrm{NaHCO}_{3}$, sob atmosfera úmida de $5 \%$ de $\mathrm{CO}_{2}$.

\subsubsection{Tripomastigotas de cultivo}

As células $\mathrm{CHO}-\mathrm{K}_{1}$ foram infectadas com $3 \times 10^{7}$ tripomastigotas por garrafa (75 $\mathrm{cm}^{2}$ ) em meio RPMI 1640 contendo $10 \%$ de SFB e incubadas a $37{ }^{\circ} \mathrm{C}$ durante 5 horas, sob atmosfera úmida com $5 \%$ de $\mathrm{CO}_{2}$, como descrito por Tonelli et al. (2004). Após 5 horas, as células foram lavadas com PBS (2X) e acrescidas de meio RPMI 1640 contendo $10 \%$ de SFB e incubadas durante 24 horas nas mesmas condições descritas acima. No dia seguinte, as células foram lavadas com PBS, acrescidas de meio RPMI 1640 contendo $2 \%$ de SFB e incubadas a $33^{\circ} \mathrm{C}$. Os parasitos foram coletados entre $5^{\circ}-10^{\circ}$ dia pósinfecção, contados em câmara de Neubauer e utilizados em experimentos posteriores.

\subsubsection{Tripomastigotas metacíclicos}

Os tripomastigotas metacíclicos foram obtidos por diferenciação de formas epimastigotas $\left(5 \times 10^{6}\right.$ células/mL) em meio TAU-3AAG (Triatomine Artificial Urine) pH 6,0, que contém $\mathrm{CaCl}_{2} 2 \mathrm{mM}, \mathrm{KCl} 17 \mathrm{mM}, \mathrm{MgCl}_{2} 2 \mathrm{mM}, \mathrm{NaCl} 190 \mathrm{mM}$, tampão fosfato $8 \mathrm{mM}$, suplementado com L-aspartato $2 \mathrm{mM}$, L-glutamato $50 \mathrm{mM}$, e L-prolina e glicose $10 \mathrm{mM}$ cada um (CONTRERAS et al., 1985).

\subsubsection{Purificação dos tripomastigotas metacíclicos}

As culturas contendo formas metacíclicas obtidas a partir da diferenciação de epimastigotas foram purificadas por retenção diferencial numa matriz de troca iônica (DEAE-celulose) (DE SOUSA, 1983). A cultura contendo formas epimastigotas e tripomastigotas metacíclicos foi lavada duas vezes com PBS ( $\mathrm{NaCl} 137 \mathrm{mM} ; \mathrm{KCl} 2,6$ $\mathrm{mM} ; \mathrm{Na}_{2} \mathrm{HPO}_{4} 8 \mathrm{mM} ; \mathrm{KH}_{2} \mathrm{PO}_{2}$ 1,4 mM pH 7,4) suplementado com $2 \%$ de glicose e ressuspendida em aproximadamente $2 \mathrm{~mL}$ da mesma solução. Esse volume foi adicionado à matriz de DEAE-celulose previamente empacotada numa coluna e 
equilibrada com 5 volumes de coluna de PBS-2\% glicose. A saída dos tripomastigotas metacíclicos foi acompanhada por microscopia de luz, analisando-se alíquotas de aproximadamente $1 \mathrm{~mL}$ coletadas a partir do momento da aplicação do material à coluna. Os tripomastigotas metacíclicos purificados foram então contados e utilizados em experimentos posteriores.

\subsubsection{Amastigotas e epimastigotas intracelulares}

As formas amastigotas e epimastigotas intracelulares foram obtidas a partir de infecção de células $\mathrm{CHO}-\mathrm{K}_{1}$ com tripomastigotas em meio RPMI acrescido de $2 \%$ de SFB, incubadas por 3 horas a $37{ }^{\circ} \mathrm{C}$ em estufa de $\mathrm{CO}_{2}$ como descrito por Tonelli et al.(2004). Brevemente, após a incubação, as culturas foram lavadas duas vezes com PBS e mantidas a $33^{\circ} \mathrm{C}$ em meio RPMI contendo $2 \%$ de SFB. Nessas condições de ensaio, o ciclo intracelular do parasito acontece em forma sincrônica, obtendo-se majoritariamente formas amastigotas entre $2^{\circ}-3^{\circ}$ dia pós-infecção e formas epimastigotas intracelulares entre o $4^{\circ}-5^{\circ}$ dia pós-infecção.

\subsubsection{Purificação de formas intracelulares}

As células $\mathrm{CHO}-\mathrm{K}_{1}$ contendo amastigotas ou epimastigotas intracelulares foram lavadas duas vezes com PBS e lisadas com solução de PBS contendo 0,01\% de SDS. As células que permaneceram aderidas foram removidas da garrafa, com auxílio de um raspador, na presença de $10 \mathrm{~mL}$ de PBS contendo $20 \%$ de soro fetal bovino. A suspensão obtida foi centrifugada a $480 \mathrm{x}$ g durante 5 minutos para eliminar os resíduos celulares e o sobrenadante foi novamente centrifugado a $4.300 \mathrm{x}$ g durante 10 minutos. $\mathrm{O}$ sedimento

foi lavado e ressuspenso em meio RPMI sem soro, contado em câmara de Neubauer e os parasitos intracelulares utilizados em experimentos posteriores.

\subsection{Manipulação de DNA}

\subsubsection{Extração de DNA genômico de T. cruzi}

A obtenção de DNA genômico de $T$. cruzi foi feita a partir de formas epimastigotas. Os epimastigotas de $T$. cruzi (aproximadamente $5 \times 10^{6}$ células $/ \mathrm{mL}$ ) foram lavados com PBS por centrifugação a $6.000 \mathrm{x}$ g por 5 minutos a $4{ }^{\circ} \mathrm{C}$. Posteriormente as células foram homogeneizadas em $200 \mu \mathrm{L}$ de tampão de lise (Tris-HCl 0,2 M; EDTA $0,01 \mathrm{M}$; SDS 0,5\% v/v, pH 8,0) com adição de $50 \mu \mathrm{g} / \mathrm{mL}$ de proteinase $\mathrm{K}$ e incubadas à temperatura ambiente por 5 minutos. Após esse período, o DNA da amostra foi extraído por tratamento com fenol/clorofórmio. A fase aquosa foi recuperada por centrifugação a $6.000 \mathrm{x}$ g por 5 minutos. O DNA foi precipitado com 2 volumes de isopropanol gelado e 
centrifugado a $10.000 \mathrm{x}$ g por 15 minutos. Os sobrenadantes foram descartados e o DNA precipitado lavado com 3 volumes de etanol $70 \%$ e centrifugado a 6.000 x g por 5 minutos. A amostra de DNA foi seca à temperatura ambiente e ressuspensa em $150 \mu \mathrm{l}$ de solução TE (Tris-HCl 10mM; EDTA 1mM, pH 8,0).

\subsubsection{Dosagem de DNA}

A quantificação do DNA foi realizada através da leitura em espectrofotômetro (Thermo Scientific Evolution 300) a $260_{\mathrm{nm}}$ e $280_{\mathrm{nm}}$. O fator utilizado para a conversão de $\mathrm{DO}_{260}$ em concentração de DNA foi de $50 \mu \mathrm{g} / \mathrm{ml}$ por cada unidade de $\mathrm{DO}_{260}$, de acordo com o protocolo descrito por Sambrook et al., (1989). As razões entre as leituras Abs260 $0_{\mathrm{nm}} / \mathrm{Abs} 280_{\mathrm{nm}}$ foram calculadas para verificar a pureza do DNA. A amostra foi considerada pura quando os valores estavam entre 1,8 e 2,0. Alternativamente, a concentração de DNA foi determinada em aparelho NanoDrop (Spectrophotometer ND1000).

\subsubsection{Eletroforese em gel de agarose}

As eletroforeses dos fragmentos de DNA foram conduzidas em gel de agarose 0,7\% - 1\% (p/v) em tampão TAE 1X (0,04 M TRIS, 1 mM EDTA, pH 8,0 ajustado com ácido acético). Antes da aplicação adicionou-se ao DNA o tampão de amostras (0,25\% de azul de bromofenol; $0,25 \%$ de xileno cianol e $20 \%$ de glicerol). O padrão de peso molecular utilizado foi $1 \mathrm{~kb}$ Plus DNA Ladder (Fementas $\left.{ }^{\circledR}\right)$. As corridas eletroforéticas foram conduzidas a $100 \mathrm{~V}$. Após a corrida os géis foram corados com brometo de etídio (solução estoque $0.5 \mu \mathrm{g} / \mathrm{ml}$ ), sob agitação por 15 minutos. Os géis foram visualizados no transiluminador sob fonte de luz UV e fotografados em sistema ImageQuant ${ }^{\circledR} 300$ (GE Healthcare).

\subsubsection{Clonagem de um gene putativo da PRODH de T. cruzi}

A seqüência do gene putativo da PRODH encontra-se depositada no banco de dados do genoma de T. cruzi do Sanger Center (www.genedb.org). Onde obtivemos duas seqüências com os seguintes números sistemáticos: Tc00.1047053511237.30 e Tc00.1047053506411.30, sendo que a primeira delas refere-se a um pseudogene de PRODH, o que nos levou a escolher o segundo gene.

\subsubsection{Reações de amplificação de DNA por PCR}

Com base na sequiência gênica da PRODH encontrada, foram desenhados e sintetizados oligonucleotídeos com sítios de clivagem para as endonucleases de restrição EcoRI e Bam HI (como destacado na Figura 8), possibilitando a amplificação do 
fragmento de interesse. Nas reações de PCR foram usadas quantidades de DNA genômico (molde) variando entre 25 e 100 ng, oligonucleotídeos na concentração de 0.2 pmol/ $\mu 1$, dNTPs $0,2 \mathrm{mM}$, concentrações finais de $2 \mathrm{mM} \mathrm{MgCl}_{2}$ e 2,5U da enzima Taq DNA polimerase (Fermentas®). As condições de amplificação compreenderam 35 ciclos com desnaturação a $94{ }^{\circ} \mathrm{C}$ por 1 minuto, anelamento dos oligos ao DNA molde a $55{ }^{\circ} \mathrm{C}$ por 1 minuto e extensão da cadeia nucleotídica a $72{ }^{\circ} \mathrm{C}$ por 2 minutos, além de uma extensão final adicional a $72{ }^{\circ} \mathrm{C}$ durante 5 minutos. $\mathrm{O}$ produto de PCR obtido foi clonado em vetor pGEM T Easy ${ }^{\circledR}$ (PROMEGA), segundo indicações do fabricante, e subclonado no vetor pAE para expressão em bactéria e pYES para ensaios de complementação heteróloga. As construções obtidas foram confirmadas por seqüenciamento, como descritas a seguir.

\subsubsection{Seqüenciamento de DNA}

As reações de seqüenciamento foram realizadas pelo Método de Sanger (Sanger, Nicklen et al., 1977), utilizando os oligonucleotídeos T7, M13 direto e reverso, e o kit de seqüenciamento de DNA BigDye ${ }^{\mathrm{TM}} 3.1$ (Applied Biosystems) segundo instruções do fabricante. As reações foram resolvidas num seqüenciador automático ABI 3100 (Applied Biosystems). Os alinhamentos e comparações entre as seqüências foram realizados mediante o uso dos programas Align versão 6.2.0, BLAST versão 2.2.19 (NCBI), BioEdit versão 7.0.0 e outros disponíveis.

\subsubsection{Digestão com enzimas de restrição, isolamento e purificação de} fragmentos de DNA, ligação e seqüenciamento

As reações de digestão do DNA foram realizadas com as endonucleases de restrição adequadas segundo as especificações e tampões recomendados pelos fabricantes (Fermentas $\left.{ }^{\circledR}\right)$. Nas reações foram utilizadas cerca de 2 unidades de enzima para cada $\mu \mathrm{g}$ de DNA e a mistura de reação incubada por 2 horas a $37^{\circ} \mathrm{C}$. A separação e extração de fragmentos de DNA obtidos a partir dos cortes foi realizada por corrida eletroforética em géis de agarose e posterior purificação mediante uso do sistema "NucleoSpin®ExtractII" (Macherey-Nagel) de acordo com as indicações do fabricante. As análises qualitativas e quantitativas do DNA foram feitas como descrito nos itens 3.2.2 e 3.2.3 Nas reações de ligação foram usados o vetor de interesse e o fragmento de DNA digeridos com as enzimas adequadas, empregando-se a razão molar inserto:vetor equivalente a 3:1. Além

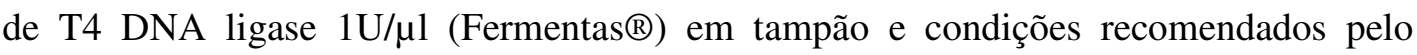
fabricante. Em todos os casos, o volume de reação total foi utilizado para transformar as 
células de E. coli (DH5a) como descrito no item 3.5.3. Os clones obtidos contendo o fragmento de DNA de tamanho correspondente ao inserto (1701 pb) foram submetidos a seqüenciamento como já descrito.

\subsubsection{Extração de DNA plasmidial em pequena escala (Mini-prep)}

Os DNAs plasmidiais dos clones obtidos nas transformações de células de E. coli (DH5 $\alpha$ ) foram extraídos pelo método de lise alcalina, como descrito por Sambroock et al. (1989). Uma colônia de bactéria recombinante cultivada a $37{ }^{\circ} \mathrm{C}$ por 16 horas em $2 \mathrm{~mL}$ de meio LB com o antibiótico adequado foi centrifugada a 3.000 x g por 10 minutos e homogeneizada em $300 \mu \mathrm{L}$ de solução I (Tris-HCl 25 mM; glicose $50 \mathrm{mM}$; EDTA 10 mM, pH 8,0) contendo RNase A $100 \mu \mathrm{g} / \mathrm{mL}$. Em seguida foram adicionados $300 \mu \mathrm{L}$ de solução II (hidróxido de sódio 0,2M; SDS 1\%) misturando-se delicadamente. Após 5 minutos de incubação à temperatura ambiente, foram acrescentados $300 \mu \mathrm{L}$ de solução III (ácido acético glacial $5 \mathrm{M}$; acetato de potássio $3 \mathrm{M}$ ) e a suspensão misturada por inversão e incubada por 30 minutos no gelo. Em seguida a suspensão foi centrifugada a $6.000 \mathrm{x} \mathrm{g}$ por 10 minutos. O sobrenadante recuperado foi precipitado com $400 \mu \mathrm{L}$ de isopropanol e novamente centrifugado a $6.000 \mathrm{x}$ g por 20 minutos. $\mathrm{O}$ precipitado formado foi lavado com $600 \mu \mathrm{L}$ de etanol 70\% gelado, submetido a nova centrifugação, seco e solubilizado em $30 \mu \mathrm{L}$ de tampão TE. A integridade do DNA foi confirmada após eletroforese em gel de agarose $1 \%$ e coloração com brometo de etídio.

\subsection{Manipulação de RNA}

\subsubsection{Extração de RNA}

O RNA usado foi obtido das várias formas do ciclo celular T. cruzi como descrito no item 3.7 e também das diferentes linhagens de $S$. cerevisiae. As células mantidas em fase exponencial de crescimento foram lavadas duas vezes por centrifugação com PBS. Após a última centrifugação, os precipitados foram homogeneizados em $1 \mathrm{~mL}$ do reagente TRIzol ${ }^{\circledR}$ (Invitrogen) e mantidos à temperatura ambiente por 5 minutos. Em seguida foram acrescentados $200 \mu \mathrm{l}$ de clorofórmio para cada $1 \mathrm{~mL}$ de TRIzol e as misturas homogeneizadas em vórtex por 15 segundos, seguido de centrifugação $10.000 \mathrm{x}$ g a $4{ }^{\circ} \mathrm{C}$ por 10 minutos. As fases aquosas (contendo o RNA) foram extraídas e precipitadas com $500 \mu 1$ de isopropanol por incubação a $-80^{\circ} \mathrm{C}$ durante a noite. Após esse período, as amostras foram centrifugadas a 10.000 x g, $4{ }^{\circ} \mathrm{C}$ por 20 minutos, e os precipitados lavados com $1 \mathrm{~mL}$ de etanol $75 \%$ preparado em água tratada com DEPC ( $0,1 \%$ de dietilpirocarbonato, $\mathrm{H}_{2} \mathrm{O}$-DEPC). Os RNAs obtidos foram solubilizados em 20 
$\mu 1$ de $\mathrm{H}_{2} \mathrm{O}$-DEPC e armazenados a $-80^{\circ} \mathrm{C}$ até o momento do uso. As concentrações de RNA foram estimadas por medida da absorbância a $260 \mathrm{~nm}$, sendo sua integridade analisada por eletroforese em gel de agarose 1,5\% em tampão MOPS 1X (MOPS 20 mM, acetato de sódio $5 \mathrm{mM}$; EDTA 0,1 mM e formaldeído 3,5\%, pH 7,0) (Figura 9).

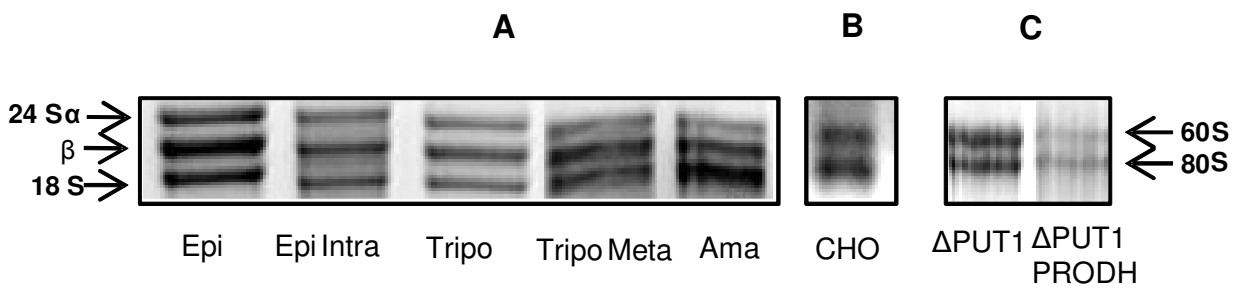

Figura 9. Qualidade dos RNAs ribossomais obtidos a partir das diferentes fases do ciclo de vida de $T$. cruzi, células de mamífero e $S$. cerevisiae. (A) As abreviações epi, epi intra, tripo, tripo meta e ama referem-se às formas epimastigota de cultura, epimastigota intracelular, tripomastigota de cultura, tripomastigota metacíclico e amastigota, respectivamente. (B) RNAs ribossomais de células de mamíferos $(\mathrm{CHO})$ utilizadas como controle. (C) RNAs ribossomais de levedura $S$. cerevisiae.

\subsubsection{Quantificação dos transcritos do gene PRODH por PCR quantitativo (qRT-PCR)}

Os oligonucleotídeos específicos para os genes selecionados foram desenhados utilizando-se o programa Primer Express 3.0. Este programa permitiu a otimização do desenho dos oligonucleotídeos para a reação de RT-PCR quantitativo (em tempo real). As seqüências correspondentes estão listadas na Figura 8. Para esta metodologia deve ser considerado que o produto de PCR ideal deve ter entre 50 e $150 \mathrm{pb}$ e sua temperatura de dissociação deveria ser próxima aos $80{ }^{\circ} \mathrm{C}$ (PONCHEL et al., 2003). As análises do RNAm por PCR em tempo real foram realizadas em um equipamento Mastercycler® ep Realplex 1.5 (Eppendorf) utilizando-se o sistema de quantificação SYBR Green (Biotools, Kit Quantimix Easy Syg). As amostras de RNA foram inicialmente tratadas com DNAse e inibidor de RNAse (RNAsin), com a finalidade de eliminar possíveis contaminações das amostras com DNA. A ausência de contaminação com DNA foi ainda confirmada por PCR das amostras de RNA tratadas (ausência de produto de amplificação). Posteriormente foram realizadas as sínteses de cDNAs, utilizando $5 \mu \mathrm{g}$ de RNA total previamente tratado com DNase, $200 \mathrm{U}$ de transcriptase reversa SuperscriptII (Invitrogen), 50 ng de oligonucleotídeos (hexâmeros aleatórios) ou 250 ng de oligo-dT, 2,5 mM de dNTPs, $10 \mathrm{mM}$ de DTT, $40 \mathrm{U}$ de RNase OUT e tampão 1X da transcriptase reversa, segundo instruções do fabricante (Invitrogen). Os cDNAs obtidos foram diluídos 
em água milli- $Q$ para a concentração final de $2 \mathrm{ng} / \mu \mathrm{L}$. Em seguida, foram realizadas a reações de RT-PCR utilizando 50-100 ng de cada cDNA como molde, 3,2 pmoles de oligonucleotídeo direto e reverso e $10 \mu \mathrm{L}$ de SYBR Green (Quantimix EASY SYG, Biotools), sob os seguintes parâmetros: $95^{\circ} \mathrm{C}$ por 2 min, 40 ciclos de $95^{\circ} \mathrm{C}$ por $15 \mathrm{seg}$ e $57^{\circ} \mathrm{C}$ por $15 \mathrm{seg}, 68^{\circ} \mathrm{C}$ por $20 \mathrm{seg}$.

\subsubsection{Análise dos dados}

Os dados foram analisados usando o software Realplex e como sistema normalizador foi utilizado o gene gliceraldeído-3-fosfato desidrogenase (GAPDH) (SILBER et al., 2009). A especificidade dos produtos amplificados foi avaliada pela análise das curvas de dissociação geradas pelo aparelho. Para cada amostra foi obtido o $\mathrm{Ct}$ (threshold cycle) que é definido como o número de ciclos requeridos para que o sinal de fluorescência supere uma linha de base obtida estatísticamente.

A razão relativa da abundância de transcritos do gene PRODH em relação ao normalizador (GAPDH) foi calculada através da diferença entre as médias dos Cts de cada amostra e a média dos Cts do normalizador, de acordo com a seguinte fórmula:

$\Delta \mathrm{Ct}=\mathrm{Ct}_{\text {amostra }}-\mathrm{Ct}_{\text {normalizador. }}$

O resultado obtido foi elevado à potência de base 2, já que o valor de $\mathrm{Ct}$ é proporcional a fase logarítmica do gene alvo na amostra da PCR (PFAFFL, 2001). Os ensaios foram feitos em triplicata. A média e o desvio padrão foram obtidos dos valores dos Cts dessas repetições.

\subsection{Manipulação de bactérias}

\subsubsection{Bactérias}

As linhagens de E. coli utilizadas foram crescidas a $37^{\circ} \mathrm{C}$ em meio LB (triptona 10 $\mathrm{g} / \mathrm{L}$, extrato de levedura $5 \mathrm{~g} / \mathrm{L}$ e $\mathrm{NaCl} 10 \mathrm{~g} / \mathrm{L}$, com $\mathrm{pH}$ de 7,5) líquido ou sólido, suplementadas quando necessário com os antibióticos ampicilina $(100 \mu \mathrm{g} / \mathrm{mL})$ e cloranfenicol $(50 \mu \mathrm{g} / \mathrm{ml})$ para seleção de colônias portadoras de plasmídeo com marca de resistência, $20 \mu \mathrm{g} / \mathrm{mL}$ de X-gal (5-bromo-4-cloro-3-indolil ß-galactopiranosídeo) e $1 \mathrm{mM}$ de IPTG (Isopropil ß-galactopiranosídeo) para seleção de colônias brancas e azuis.

\subsubsection{Preparação de bactérias competentes}

Na preparação das bactérias competentes para a transformação, uma colônia de bactéria (E. coli DH5- $\alpha$ ou BL21-Codon Plus (DE3)-RIL) foi inoculada em $5 \mathrm{~mL}$ de meio LB (sem antibiótico) e cultivada a $37{ }^{\circ} \mathrm{C}$ por 16 horas com agitação $(200 \mathrm{rpm})$. No dia seguinte a cultura crescida foi diluída 1:100 em meio LB e incubada nas mesmas 
condições anteriores até atingir uma densidade ótica $\left(\mathrm{DO}_{600}\right)$ entre 0,5 e 0,6. As células foram então coletadas por centrifugação a 3.000 x g por 10 minutos a $4{ }^{\circ} \mathrm{C}$ e lavadas com $500 \mathrm{~mL}$ de água milli-Q estéril gelada. O sedimento obtido foi homogeneizado em $50 \mathrm{~mL}$ de solução gelada de $\mathrm{CaCl}_{2}$ 0,1 $\mathrm{M}$ e incubado por aproximadamente 1 hora em gelo. Em seguida a suspensão celular foi centrifugada a 3.000 x g por 15 minutos a $4{ }^{\circ} \mathrm{C}$ e o sedimento celular homogeneizado com $2 \mathrm{~mL}$ de solução gelada de $\mathrm{CaCl}_{2} 0,1 \mathrm{M}$. As células competentes foram usadas imediatamente ou estocadas a $-70{ }^{\circ} \mathrm{C}$ em presença de glicerol $20 \%(\mathrm{v} / \mathrm{v})$.

\subsubsection{Transformação de bactérias competentes}

As alíquotas das suspensões de células competentes $(100 \mu \mathrm{L})$ foram descongeladas em gelo, transferidas para tubos de ensaio estéreis e incubadas com o DNA plasmidial ou produtos de ligações por 30 minutos. Em seguida as células foram submetidas a choque térmico $\left(42^{\circ} \mathrm{C}\right.$ por 2 minutos) e imediatamente incubadas em gelo por mais 10 minutos. Após a recuperação das células em meio LB por 1 hora a $37^{\circ} \mathrm{C}$ com agitação $(200 \mathrm{rpm})$, as bactérias foram plaqueadas em meio LB sólido contendo o respectivo antibiótico e/ou IPTG e X-Gal para seleção das colônias recombinantes.

\subsubsection{Expressão das proteínas recombinantes em E. coli}

O gene da PRODH foi subclonado no vetor pAE para expressão em E. coli linhagem BL21-Codon Plus (DE3)-RIL. Para isso, as bactérias contendo o plasmídeo foram crescidas em um pré-inoculo a $37{ }^{\circ} \mathrm{C}$ em meio LB com ampicilina (100 $\left.\mu \mathrm{g} / \mathrm{mL}\right)$ e cloranfenicol $(50 \mu \mathrm{g} / \mathrm{ml})$ por 16 horas. O pré-inóculo foi diluído 1:100 no mesmo meio e incubado a $37{ }^{\circ} \mathrm{C}$, sob agitação $(200 \mathrm{rpm})$ até a cultura atingir uma DO de 0,6. Em testes preliminares, a expressão da proteína recombinante foi induzida com IPTG na concentração de $0,5 \mathrm{mM}$ por 4 horas. Alíquotas foram retiradas ao longo do tempo. Após centrifugação, as amostras foram suspensas em $100 \mu 1$ de tampão de amostra para SDSPAGE 1X (Tris-HCl 62,5 mM pH 6,8, SDS 2,3\%, glicerol 10\%, azul de bromofenol 0,01\%, $20 \mathrm{mM}$ mercaptoetanol). As amostras foram aquecidas a $95{ }^{\circ} \mathrm{C}$ por 5 minutos e aplicadas em gel SDS-PAGE 10\% segundo o método descrito por Laemmli (1970). Os géis foram corados com uma solução de Coomassie Brilliant Blue. Com base nos resultados dos testes preliminares e com o objetivo de otimizar a expressão da proteína em forma solúvel, otimizou-se a indução da expressão da proteína. Então, as culturas foram induzidas a $20{ }^{\circ} \mathrm{C}$ por 16 horas com agitação $(200 \mathrm{rpm})$ com $0,3 \mathrm{mM}$ de IPTG. 
Nestas condições deu-se início a expressão da proteína em larga escala (a partir de 500 $\mathrm{mL}$ de cultura).

\subsubsection{Purificação da PRODH recombinante}

As construções realizadas foram desenhadas para se obter proteínas recombinantes possuindo 6-histidinas no extremo N-terminal (esses resíduos são codificados pelo vetor). Isso permite a purificação dessas proteínas num único passo em coluna de afinidade de

níquel Ni-NTA agarose $\left(\right.$ Qiagen $\left.^{\circledR}\right)$. Os procedimentos de purificação foram realizados a partir de extratos provenientes de culturas de bactérias crescidas em $500 \mathrm{~mL}$ de LB a 20 ${ }^{\circ} \mathrm{C}$ por 16 horas, induzidas com $0,3 \mathrm{mM}$ de IPTG. As culturas pós-indução foram centrifugadas a $5.000 \mathrm{x} g$ por 15 minutos a $4{ }^{\circ} \mathrm{C}$ e os sedimentos homogeneizados em tampão de lise gelado (Tris-HCl 50 mM; $\mathrm{NaCl} 300$ mM, pH 7,4) com adição de $50 \mu 1 / \mathrm{mL}$ de coquetel de inibidores de proteases (AEBSF, E-64, aprotinina, pepstatina A, leupeptina e cloridrato de bestatina). Em seguida, as células foram submetidas à lise por sonicação com 4 pulsos de 1 minuto e intervalos de descanso em gelo de 1 minuto entre os pulsos. Após a sonicação, adicionou-se $0,1 \%$ de Triton X-100 ao lisado, seguida de centrifugação a 20.000 x g por 30 minutos a $4^{\circ} \mathrm{C}$, separando-se a fração solúvel (sobrenadante) da insolúvel (precipitado).

A fração solúvel foi utilizada para dar seguimento à purificação em coluna de resina de níquel (Ni-NTA agarose Qiagen ${ }^{\circledR}$ ). Essa coluna foi previamente equilibrada com 5 volumes de coluna (V) com tampão A (Tris-HCL 20 mM; 500 mM NaCl e 10 mM de imidazol pH 7,4). O sobrenadante foi então aplicado à coluna, seguido de lavagem com 10 V de tampão B (Tris-HCL 50 mM; 150 mM NaCl e 20mM de imidazol, pH 7,4) para a retirada de proteínas não ligantes à coluna. A proteína recombinante foi eluída com $5 \mathrm{~V}$ de tampão C (Tris-HCL $20 \mathrm{mM} ; 500 \mathrm{mM} \mathrm{NaCl}$ e $500 \mathrm{mM}$ de imidazol pH 7,4). As frações contendo a proteína recombinante foram concentradas por ultrafiltração usando filtros Amicon-ultra/30.000 MWCO (Millipore). As proteínas foram quantificadas como descrito a seguir, e posteriormente, as frações obtidas foram analisadas em gel SDSPAGE $10 \%$.

\subsection{Manipulação de leveduras}

\subsubsection{Leveduras}

As cepas de $S$. cerevisiae foram cultivadas a $30^{\circ} \mathrm{C}$ em meio YPD (extrato de levedura $1 \%$, peptona $2 \%$ e glicose $2 \%$ ) acrescido de $200 \mu \mathrm{g} / \mathrm{L}$ de geneticina , em meio mínimo SD composto de base nitrogenada de leveduras sem aminoácidos $(0,67 \%(\mathrm{p} / \mathrm{v})$, 
suplementado com os aminoácidos fenilalanina $50 \mathrm{mg} / \mathrm{L}$, triptofano $100 \mathrm{mg} / \mathrm{L}$, histidina $100 \mathrm{mg} / \mathrm{L}$, ácido glutâmico $100 \mathrm{mg} / \mathrm{L}$, ácido aspártico $100 \mathrm{mg} / \mathrm{L}$, valina $100 \mathrm{mg} / \mathrm{L}$, arginina $20 \mathrm{mg} / \mathrm{L}$, metionina $20 \mathrm{mg} / \mathrm{L}$, tirosina $30 \mathrm{mg} / \mathrm{L}$, isoleucina $30 \mathrm{mg} / \mathrm{L}$, lisina 30 $\mathrm{mg} / \mathrm{L}$, leucina $250 \mathrm{mg} / \mathrm{L}$, treonina $200 \mathrm{mg} / \mathrm{L}$ e serina $375 \mathrm{mg} / \mathrm{L}$ e a base adenina $50 \mathrm{mg} / \mathrm{L}$ e $2 \%$ de galactose ( $\mathrm{pH}$ 6.5), acrescido de $200 \mu \mathrm{g} / \mathrm{L}$ de geneticina, ou em meio SD utilizando prolina $(0,1 \%)$ como única fonte de nitrogênio. Os meios sólidos contêm adicionalmente $1,5 \%$ de ágar. Estoques de E. coli e $S$. cerevisiae foram realizados em meio apropriado com $20 \%$ de glicerol e mantidos a $-80{ }^{\circ} \mathrm{C}$.

\subsubsection{Transformação de leveduras}

Células provenientes de uma única colônia da cepa de Sacharomyces cerevisiae (YLR142W/PUT1) foram inoculadas em $5 \mathrm{~mL}$ de meio YPD e incubadas durante 16 horas a $30^{\circ} \mathrm{C}$ sob agitação (200 rpm). Após este período, adicionou-se 2,5 x $10^{8}$ células do pré-inóculo em $50 \mathrm{~mL}$ de YPD e a cultura foi incubada a $30^{\circ} \mathrm{C}$ com agitação até atingir um número de $2 \times 10^{7}$ células/mL. Após o crescimento, as células foram coletadas por centrifugação a 3.000 x g por 5 minutos a $20{ }^{\circ} \mathrm{C}$, lavadas com $25 \mathrm{~mL}$ de água estéril e novamente centrifugadas. As células foram homogeneizadas em $1 \mathrm{~mL}$ de água estéril e alíquotas de $100 \mu \mathrm{l}$ contendo $1 \times 10^{8}$ células foram utilizadas para cada transformação. Nessas alíquotas de leveduras competentes, adicionou-se $5 \mu \mathrm{g}$ do produto de ligação de interesse (PRODH/pYES ou somente pYES), $25 \mu \mathrm{L}$ ssDNA $2 \mathrm{mg} / \mathrm{mL}$ (DNA de esperma de salmão) previamente desnaturado a $95{ }^{\circ} \mathrm{C}, 240 \mu \mathrm{L}$ de PEG $335050 \%$ (p/v) (polietilenoglicol), $36 \mu \mathrm{L}$ de acetato de lítio 1M. A mistura foi homogeneizada delicadamente e submetida a choque térmico a $42{ }^{\circ} \mathrm{C}$ por 40 min. Após centrifugação a $13.000 \mathrm{x} \mathrm{g}$ por 30 segundos, as células foram suspensas no sobrenadante residual e plaqueadas em meio sólido seletivo $\left(\mathrm{SD}^{\text {-ura }}\right)$ suplementado com os aminoácidos adequados de acordo com as marcas genéticas para seleção por auxotrofia, e galactose $2 \%$ (indutor do promotor plasmidial). As placas foram incubadas a $30{ }^{\circ} \mathrm{C}$ por 48 a 72 horas. Como controle negativo do ensaio, a levedura foi transformada nas mesmas condições anteriores exceto pela ausência de DNA plasmidial.

\subsubsection{Quantificação de glutationa total, oxidada (GSSG) e reduzida (GSH)}

A quantificação de glutationa total e oxidada foi realizada segundo Demasi et al. (2001). As diferentes linhagens de leveduras descritas no item 3.4 foram crescidas em

meio $\mathrm{SD}^{\text {-ura }}$ e galactose $2 \%$ até a fase exponencial de crescimento. Uma massa de $200 \mathrm{mg}$ das diferentes linhagens foram ressuspensas em $150 \mu \mathrm{L}$ de ácido sulfosalicílico 3,5\% 
com 100 mg de esferas de vidros (glass beads) e rompidas por ação mecânica em vórtex durante 15 minutos por duas vezes a $4{ }^{\circ} \mathrm{C}$. Essas suspensões foram centrifugadas a 12.000 x g por 5 minutos a $4{ }^{\circ} \mathrm{C}$ para a retirada dos sobrenadantes. A determinação da glutationa total foi realizada com o sobrenadante final pela reação com DNTB (2,4-dinitrofenil tiocianato) $76 \mathrm{mM}$ na presença de glutationa reductase $0,12 \mathrm{U} / \mathrm{mL}$ e NADPH $0,27 \mathrm{mM}$ em um espectrofotômetro operando a um comprimento de onda de $412 \mathrm{~nm}$ a $30{ }^{\circ} \mathrm{C}$ sob agitação constante. Os volume das amostras reservados para a determinação de GSSG foram previamente incubados em gelo por 1 hora com N-etilmaleimida $5 \mathrm{mM}$ após o ajuste do valor do $\mathrm{pH}$ até 7,0 com $\mathrm{NaOH}$ e analisados nas mesmas condições. A concentração de GSH foi determinada matematicamente pela diferença entre glutationa total e a GSSG.

\subsection{Preparação de extratos protéicos}

Os extratos protéicos foram obtidos de células em fase exponencial de crescimento $\left(5 \times 10^{8}\right.$ de células $\left./ \mathrm{mL}\right)$. As células foram lavadas duas vezes por centrifugação com PBS e homogeneizadas em Tampão de Lise (Tris $50 \mathrm{mM}$; sacarose 0,25 M; $\mathrm{NaCl} 100 \mathrm{mM} ; 0.2 \%$ Triton $\mathrm{X}-100, \mathrm{pH} 7.6)$ na presença de $1 \%$ de coquetel contendo inibidores de proteases (AEBSF, E-64, aprotinina, pepstatina A, leupeptina e cloridrato de bestatina). As células de T. cruzi foram submetidas à lise por sonicação através de 4 ciclos de 20 segundos com intervalos de descanso em gelo de 1 minuto entre os ciclos. Já as leveduras foram rompidas pela ação de esferas de vidro (aproximadamente 1/3 do volume da suspensão de células) e agitação mecânica em vórtex por 2 minutos (pulsos de 30 segundos) com intervalos de 2 minutos no gelo entre os ciclos. Após centrifugação a 7.000 x g por 10 minutos, os sobrenadantes contendo os extratos protéicos foram utilizados para a determinação de atividade enzimática e ensaios de Western blotting.

\subsection{Quantificação de Proteínas}

A dosagem de proteínas foi feita em triplicata pelo método de Bradford (Bradford, 1976), utilizando-se uma solução de BSA (albumina bovina sérica) como padrão para a construção de curvas de calibração.

\subsection{Obtenção de anticorpos específicos por predição da região antigênica}

A seqüência de aminoácidos da proteína PRODH foi analisada para a detecção de regiões com maior probabilidade de comportamento antigênico mediante o uso do programa DNAStar ${ }^{\mathrm{TM}}$ versão 7.1. Uma região predita dessa seqüência foi selecionada $(\mathrm{N}$ - 
YTEDRVFNDLTRSELE-C) por ter os melhores índices de hidrofobicidade e antigenicidade predita segundo o algoritmo descrito por Kyte e Doolittle (1982). Peptídeos sintéticos cuja sequiência corresponde à seguinte região da proteína $\mathrm{N}$ YTEDRVFNDLTRSELE-C (Figura 10) foram acoplados à proteína carreadora KLH (Keyhole limpet hemocyanin) seguindo o protocolo fornecido pelo fabricante (Pierce). Em um volume contendo a mesma proporção em massa de $\mathrm{KLH}(0,5 \mathrm{mg})$ e peptídeo sintético $(0,5 \mathrm{mg})$, adicionou-se $0,1 \%$ de glutaraldeído. Após uma incubação de 2 horas à temperatura ambiente sob agitação constante, $200 \mathrm{mM}$ de glicina foi acrescentada à solução para bloquear os grupos aldeído livres. A solução foi novamente incubada por 1 hora na mesma condição anterior. A amostra foi dialisada e a concentração de proteína determinada. A produção de anticorpos policlonais a partir do conjugado peptídeo/KLH foi realizada mediante a imunização de cinco camundongos Balb/c machos, de aproximadamente cinco semanas de idade. A primeira imunização foi realizada com $50 \mu \mathrm{g}$ de antígeno emulsificado em adjuvante de Freund Completo. Nos inóculos subseqüentes utilizou-se $30 \mu \mathrm{g}$ de antígeno emulsificado em adjuvante de Freund Incompleto. As aplicações foram feitas com intervalos de 7-15 dias, via intraperitoneal. Após 5 imunizações, os animais foram anestesiados e o sangue coletado por via ocular para a titulação do anticorpo. Determinada a titulação, o sangue foi coletado via punção no plexo radial e incubado a $37{ }^{\circ} \mathrm{C}$ por 30 minutos, permanecendo a $4{ }^{\circ} \mathrm{C}$ por mais 30 minutos. O soro foi coletado por centrifugação a 1.000 x $g$ por 15 minutos e armazenado a $-20^{\circ} \mathrm{C}$.

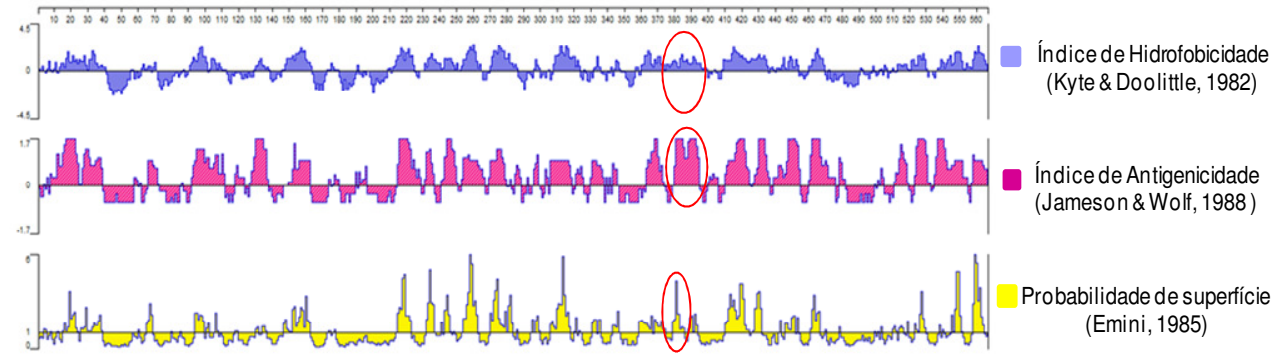

Figura 10. Representação dos índices de hidrofobicidade, antigenicidade e probabilidade de superfície para a proteína PRODH de $T$. cruzi de acordo com o programa DNAStar versão 5.00. O círculo em vermelho indica a região $\left(\mathrm{Tyr}^{380} \mathrm{e} \mathrm{Glu}^{395}\right)$ correspondente ao peptídeo sintético utilizado na obtenção de anticorpo anti-PRODH. 


\subsubsection{Purificação de anticorpo}

Para a purificação do anticorpo contra PRODH de T. cruzi, uma membrana de nitrocelulose foi incubada por 1 hora em uma solução do peptídeo/KLH $(1 \mathrm{~g} / \mathrm{mL})$. Após o bloqueio da membrana com leite 5\% em PBS, a mesma foi incubada com $2 \mathrm{~mL}$ de soro anti-PRODH (diluídos 1:10 em PBS 1X) e incubada por 1 hora à temperatura ambiente. A membrana foi então lavada três vezes por 5 minutos com PBS e incubada por 10 minutos à temperatura ambiente com $2 \mathrm{~mL}$ de solução de eluição do anticorpo (glicina 0,1M pH: 2,5 e EGTA $1 \mathrm{mM}$ ). Esse eluato foi neutralizado com igual volume de solução Tris base 0,1 M e concentrado no Centricon Plus-10 (Millipore). O anticorpo purificado foi aliquotado a $-20{ }^{\circ} \mathrm{C}$.

\subsection{Imunolocalização}

As diferentes formas dos parasitos $\left(5 \times 10^{6}\right.$ células $\left./ \mathrm{mL}\right)$ foram incubadas com o marcador mitocondrial MitoTracker® Red CMXRos (100 nM) (Molecular Probes) por 30 minutos a $28^{\circ} \mathrm{C}$. Posteriormente as células foram centrifugadas a $2.000 \mathrm{x}$ g por 5 minutos (sempre protegidas da luz) e incubadas sob leve agitação a $28^{\circ} \mathrm{C}$ por 30 minutos em $1 \mathrm{~mL}$ de meio LIT (sem soro) e novamente centrifugadas a 2.000 x g por 5 minutos à temperatura ambiente, este procedimento foi realizado duas vezes. Posteriormente, as células foram ressuspensas em $50 \mu \mathrm{L}$ de PBS. As lâminas com as preparações das células pré-tratadas com MitoTracker foram fixadas com paraformaldeído $2 \%$ à temperatura ambiente por 20 minutos. As lâminas foram lavadas três vezes com PBS-T (Triton X-100 $0,1 \%)$ e bloqueadas com PBS-T-BSA (0,1\% de BSA) durante 30 minutos, e novamente lavadas como descrito acima. Posteriormente, as lâminas foram incubadas com o anticorpo primário anti-PRODH (1:100) por 1 hora, lavadas e incubadas com anticorpo

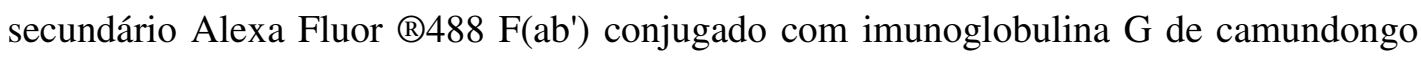
(Invitrogen ${ }^{\circledR}$ ) na diluição de 1:600 por 1 hora a $37{ }^{\circ} \mathrm{C}$. Depois de realizada mais duas lavagens rápidas foi adicionado às lâminas o corante de DNA total DAPI (Invitrogen®) (2 $\mathrm{mg} / \mathrm{mL}$ ), durante um minuto. Finalmente, as lâminas foram montadas com VECTASHIELD (Vector®). As preparações foram analisadas em microscópio confocal Carl Zeiss Meta System (modelo LSM 510 NLO) (Thornwood, NY, USA). Foram usados para o mitotracker os comprimentos de excitação de 579 nm e emissão de 599 nm, para o Alexa os comprimentos de excitação de 488 e de emissão entre 500-550, para a detecção do DAPI 740 nm de excitação e de emissão entre 435-485. O software Zeiss LSM Image Browser versão 4.2.0.121 para Windows foi utilizado para análises das imagens. 


\subsection{Localização subcelular de PRODH em extratos protéicos de T. cruzi}

As formas epimastigotas de $T$. cruzi $\left(6,4 \times 10^{8}\right.$ células $)$ foram suspensas em tampão TSEB (Tris-HCL 25 mM; sacarose 0,25 M; EDTA 1mM; $10 \mu \mathrm{M}$ E-64, pH: 7,6) suplementado com digitonina (0-5 mg, como indicado para cada caso) em um volume final de $1 \mathrm{~mL}$. Os parasitos foram incubados por 5 minutos a $25^{\circ} \mathrm{C}$ e centrifugados a $18.000 \mathrm{x} g$ por 2 minutos à temperatura ambiente. Os sobrenadantes (S) foram separados imediatamente e os precipitados $(\mathrm{P})$ lavados com 0,5 mL TSEB. Depois de centrifugados, os sobrenadantes foram descartados, e os precipitados ressuspensos $1 \mathrm{~mL}$ de tampão TSEB e lisados por sonicação (200-300 watts) com 4 pulsos de 20 segundos e intervalos de 10 segundos em gelo. A concentração de proteína das frações $\mathrm{S}$ e $\mathrm{P}$ foram determinadas pelo método de Bradford (1976). As atividades enzimáticas da piruvato quinase como marcador citosólico, da hexoquinase como marcador glicossomal e citrato sintase como marcador mitocondrial e da PRODH foram medidas em todas as frações $\mathrm{S}$ e P, como descrito a seguir (itens 3.13.5, 3.13.6 e 3.13.7). Quantidades iguais de proteína de cada fração foram submetidas a eletroforese em gel de poliacrilamida com SDS (SDSPAGE 10\%) para posterior análise por western blotting, como desrito a seguir.

\subsection{Western Blotting}

Os extratos protéicos foram obtidos como descrito no item 3.12. As proteínas separadas eletroforeticamente em géis de poliacrilamida 10\% (SDS-PAGE) foram transferidas para filtros de nitrocelulose (Hybond-C Extra, Amersham Biosciences) como descrito por Towbin et al. (1979) utilizando o sistema Panter® semi-dry (Owl). Após a transferência, as membranas foram coradas com Ponceau $\mathrm{S}(0,1 \%$ diluído em ácido acético 10\%) e descoradas com água para verificação da eficiência do processo de transferência. As membranas foram bloqueadas por 1 hora em solução TBS-T (Tris-HCl $10 \mathrm{mM}$ pH: 8,0, $\mathrm{NaCl} 150 \mathrm{mM}$ e Tween-20 0,05\%) contendo 5\% de leite desnatado. Após o bloqueio, as membranas foram incubadas com o anticorpo primário (1:500) sob leve agitação por 1 hora à temperatura ambiente e depois lavadas quatro vezes por 20 minutos com TBS-T. Procedeu-se então as incubações durante 1 hora com o anticorpo secundário, conjugado a HRP (1:5.000) (horseradish peroxidase-GE Healthcare), seguido de nova lavagem como acima descrito. Após as lavagens, os ensaios foram revelados por quimiluminescência usando o reagente ECL ("ECL ${ }^{\mathrm{TM}}$ Western Blotting Analysis System”, Amershan Biosciences) de acordo com o manual do fabricante. 


\subsection{Ensaios de atividades enzimáticas}

\subsubsection{Redução de DCICP}

A atividade da enzima PRODH foi medida através da redução de um corante utilizado como aceptor de elétron, o diclorofenolindofenol (DCICP), de acordo com Lamour et al. (2005). A reação conteve $11 \mathrm{mM}$ MOPS, $11 \mathrm{mM} \mathrm{MgCl} 2,11 \%$ (v/v) de glicerol, 0,26 mM de phenazina methosulfate e $56 \mu \mathrm{M}$ de DCICP, pH 7,5. Concentrações

variáveis de L- prolina foram adicionadas a 900-950 $\mu 1$ na solução estoque da reação, a qual foi iniciada pela adição do extrato enzimático. A atividade foi monitorada em espectrofotômetro a $600 \mathrm{~nm}$. A partir deste protocolo foram realizados ensaios de cinética enzimática.

\subsubsection{Cinética enzimática}

Os experimentos de cinética enzimática foram realizados através da medição da atividade da enzima PRODH recombinante e em extrato total de epimastigotas de T. cruzi como descrito por Lamour et al. (2005), com diferentes concentrações de prolina variando entre 0-60 $\mu \mathrm{M}$ ao longo do tempo (5 minutos). Os dados obtidos por espectofotometria nesta reação foram utilizados para realizar cálculos no programa de computador OriginPro 8.0. Sob a hipótese da PRODH ser uma enzima micaeliana, realizaram-se ajustes por regressão não-linear a uma função hiperbólica seguindo o modelo de Michaelis-Menten, e desta forma, determinados a constante $\left(k_{m}\right)$ e a velocidade máxima $\left(\mathrm{V}_{\max }\right)$ para a enzima em estudo.

\subsubsection{Detecção de pirrrolina-5-carboxilato por reação com o-Aminobenzaldeído}

O composto pirrrolina-5-carboxilato (P5C) formado a partir da oxidação da prolina pela enzima PRODH, pode ser quantificado pela reação com o cromógeno oaminobenzaldeído (OAB) que reage com o P5C formando o complexo conhecido como dihidroxiquinona, com absorbância $(443 \mathrm{~nm})$ que é proporcional à concentração do produto. A mistura da reação contendo tampão fosfato de potássio $(0,5 \mathrm{M}, \mathrm{pH} 7,5), \mathrm{L}$ prolina $(0,3 \mathrm{M})$, citocromo $\mathrm{C}\left(6 \times 10^{-4} \mathrm{M}\right)$ e extrato total de epimastigotas foi incubada em condições aeróbicas por 30 minutos a $37^{\circ} \mathrm{C}$. A reação foi parada pela adição de $0,5 \%$ de o-aminobenzaldeído, 5\% de TCA em etanol, mantida à temperatura ambiente por 20 minutos e depois centrifugada por 10 minutos. O sobrenadante foi cuidadosamente removido e a absorbância determinada a $443 \mathrm{~nm}$ contra o branco (STRECKER, 1960). Todas as reações foram feitas em triplicata. O branco foi tratado da mesma forma exceto pela adição de L-prolina. 


\subsubsection{Ensaios de atividade da PRODH com diferentes cofatores}

A reação conteve $100 \mathrm{mM}$ de carbonato de sódio pH 10,3, $20 \mathrm{mM}$ de L-prolina. Os cofatores avaliados foram $\mathrm{NAD}^{+}, \mathrm{NADP}^{+}(10 \mathrm{mM})$ ou FAD $(0,5 \mathrm{mM})$ (Sarkar et al., 2009). Em $1 \mathrm{~mL}$ desta mistura de reação foi adicionado o extrato da amostra. As mudanças na absorbância foram observadas a $340 \mathrm{~nm}$ por 5 minutos para $\mathrm{NAD}^{+}$e $\mathrm{NADP}^{+}$e a $510 \mathrm{~nm}$ por 5 minutos para FAD. Os resultados de todos estes ensaios foram expressos em nmol/min mg de proteína, calculados como se segue:

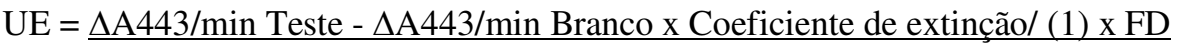

$$
\text { [proteina } \mathrm{mg} / \mathrm{ml}] \times(\mathrm{V})
$$

Onde:

UE=Unidades de atividade enzimática

$1=$ volume total (em mililitros) do ensaio.

$\mathrm{FD}=$ fator de diluição

$\mathrm{V}=$ volume (em mililitros) do extrato usado

$2.71 \mathrm{x} \mathrm{cm}^{-1}=$ coeficiente de extinção em milimolar de OAB a $443 \mathrm{~nm}$

$21 \mathrm{x} \mathrm{cm}^{-1}=$ coeficiente de extinção em milimolar de DCICP a $600 \mathrm{~nm}$

$11.3 \mathrm{x} \mathrm{cm}^{-1}=$ coeficiente de extinção em milimolar de FAD a $510 \mathrm{~nm}$

$6.22 \mathrm{x} \mathrm{cm}^{-1}=$ coeficiente de extinção em milimolar de NAD e NADH a $340 \mathrm{~nm}$

\subsubsection{Atividade da enzima citrato sintase}

O ensaio da enzima Citrato Sintase foi realizado como descrito por Srere P. A. (1970). O tampão do ensaio conteve $100 \mathrm{mM}$ Tris pH 8,0, $100 \mathrm{mM}$ ácido málico, $50 \mathrm{mM}$ ß-NAD, 2 mM de solução de acetil CoA e solução com 560 unidades/mL da enzima malato desidrogenase. $\mathrm{O}$ volume de reação utilizado foi $1 \mathrm{~mL}$ e o ensaio iniciado pela adição do extrato protéico a $37^{\circ} \mathrm{C}$. No branco da reação o extrato protéico foi omitido. No ensaio foi observado o aumento da absorbância em espectrofotômetro a $340 \mathrm{~nm}$ por 5 minutos. O cálculo de atividade foi realizado como descrito no item 3.13.4. Um controle positivo foi realizado com CS comercial $(0,03$ unidades $/ \mathrm{mL})$.

\subsubsection{Atividade da enzima piruvato quinase (PK)}

O ensaio da enzima Piruvato quinase foi realizado como descrito por Bergmeyer H.U. (1972). O tampão do ensaio conteve $100 \mathrm{mM}$ fosfato de potássio $\mathrm{pH}$ 7,6, $17 \mathrm{mM}$ de solução de fosfoenolpiruvato (PEP), 1,3 mM $\beta$-NADH, $100 \mathrm{mM}$ de solução de $\mathrm{MgSO}_{4}$, 44 mM ADP e solução de desidrogenase láctica (LDH). O volume de reação foi $1 \mathrm{~mL}$ e o ensaio iniciado pela adição do extrato protéico a $37{ }^{\circ} \mathrm{C}$. No branco da reação o extrato 
protéico foi omitido. No ensaio foi observada a diminuição da absorbância em espectrofotômetro a $340 \mathrm{~nm}$ por 5 minutos. O cálculo de atividade foi realizado como descrito no item 3.13.4. Um controle positivo foi realizado com PK comercial $(0,015$ unidades $/ \mathrm{mL})$.

\subsubsection{Atividade da enzima hexoquinase (HK)}

O ensaio da enzima Hexoquinase foi realizado como descrito por Easterby et al. (1973). O tampão do ensaio conteve $50 \mathrm{mM}$ Tris-HCL pH 7,6, $50 \mathrm{mM}$ de solução de Dglicose, $30 \mathrm{mM}$ de ATP, $200 \mathrm{mM}$ de solução de $\mathrm{MgCl}_{2}, 1 \mathrm{mM}$ de $\beta$-NADP, enzima Glicose-6-fosfato-desidrogenase (G6PD 500 unidades/mL). O volume de reação foi $1 \mathrm{~mL}$ e o ensaio iniciado pela adição do extrato protéico a $30^{\circ} \mathrm{C}$. No branco da reação o extrato protéico foi omitido. No ensaio foi observado o aumento da absorbância em espectrofotômetro a $340 \mathrm{~nm}$ por 5 minutos. O cálculo de atividade foi realizado como já descrito no item 3.13.4. Um controle positivo foi realizado com HK comercial $(0,025$ unidades $/ \mathrm{mL}$ ).

\subsection{Ensaio de ligação ao $\mathrm{Ca}^{2+}$}

Através de análises in silico no programa Prosite (SIGRIST et al., 2010) da seqüência protéica da PRODH, observou-se a presença de um possível domínio " $E F$ hand”. Os domínios EF-hand são característicos de proteínas ligantes de $\mathrm{Ca}^{2+}$. Com o intuito de verificar a capacidade ligante de $\mathrm{Ca}^{2+}$ deste domínio, foi realizado um experimento utilizando o reagente QUIN-2 (Dojindo, Japan) como previamente descrito (PINTO et al., 2003). Brevemente, a proteína recombinante PRODH foi transferida para uma membrana de PVDF (Amersham). Posteriormente essa membrana foi incubada por 2 horas em tampão contendo $60 \mathrm{mM}$ de $\mathrm{KCl}, 5 \mathrm{mM} \mathrm{MgCl} 2$ e $10 \mathrm{mM}$ imidazol-HCl pH6,8. A membrana foi novamente imersa em uma solução contendo $1 \mathrm{mM} \mathrm{de} \mathrm{CaCl}_{2}$ e incubada por 1 hora à temperatura ambiente, e posteriormente, lavada com etanol $20 \%$ por três vezes durante 6 minutos. Após lavagem com água deionizada, a membrana foi incubada com uma solução de $1 \mathrm{mM}$ de Quin 2 por 1 hora, seguido de lavagens com água deionizada. Então a membrana foi completamente seca à temperatura ambiente e o perfil de fluorescência visualizado com luz UV a $365 \mathrm{~nm}$. 


\subsection{Ensaios de estresse oxidativo}

\subsubsection{Em leveduras}

Para estudar a relação entre o conteúdo de prolina intracelular, a presença da PRODH de T. cruzi e o estresse oxidativo em leveduras, algumas condições foram préestabelecidas de acordo com o protocolo de Chen et al. (2006). As culturas de leveduras em fase exponencial de crescimento com densidade ótica $\left(\mathrm{DO}_{600}\right)$ de 0,5 foram diluídas para uma DO de 0,05 em meio apropriado (SD-URA/GAL 2\%). Essas culturas foram submetidas ao tratamento com peróxido de hidrogênio $\left(\mathrm{H}_{2} \mathrm{O}_{2}\right)$ ou $T$-Butil Hidroperóxido a uma concentração de $1 \mathrm{mM}$, na presença ou ausência de $10 \mathrm{mM}$ de L-prolina no meio de cultura e incubadas a $30^{\circ} \mathrm{C}$ sob agitação por 4 horas. Foram retiradas alíquotas a cada hora e lavadas duas vezes por centrifugação com PBS. Após os tratamentos, as alíquotas dos diferentes tempos da cultura celular foram diluídas e plaqueadas em meio YPD e incubadas a $30{ }^{\circ} \mathrm{C}$ por $48 \mathrm{~h}$. A viabilidade celular foi determinada pela contagem do número Unidades Formadoras de Colônias (UFC). O efeito do estresse foi estimado com base na variação do número de Unidades Formadoras de Colônias (UFC) em relação ao tempo de exposição ao estresse, mediante a comparação entre as células tratadas e não tratadas. A morfologia e a viabilidade celular também foram monitoradas em microscópio ótico com o uso da solução de azul de metileno (azul de metileno 0,01\% em tampão acetato de sódio 0,1 M pH 5,0). Foram contadas 300 células, em duplicata, para cada tempo analisado. A determinação da porcentagem de células viáveis foi feita através da seguinte fórmula:

$\%$ células viáveis $=(\mathrm{CT}-\mathrm{CA}) / \mathrm{CT} \times 100$

Onde CT é o número de células totais e CA é o número de células coradas.

\subsubsection{Em epimastigotas de T.cruzi}

Para a realização deste ensaio algumas condições foram padronizadas. Primeiramente, diferentes concentrações de $\mathrm{H}_{2} \mathrm{O}_{2}$ foram testadas, obtendo-se curvas doseresposta. Os epimastigotas de $T$. cruzi $\left(5 \times 10^{6}\right.$ células $\left./ \mathrm{mL}\right)$ foram incubados em PBS com diferentes concentrações de $\mathrm{H}_{2} \mathrm{O}_{2}(100,120,140,160,180$ e $200 \mu \mathrm{M})$ durante 3 horas a $28{ }^{\circ} \mathrm{C}$. Em seguida, a viabilidade celular foi estimada através do ensaio de MTT, como descrito a seguir. Desta forma, a metade da concentração máxima inibitória $\left(\mathrm{CI}_{50}\right)$ de $\mathrm{H}_{2} \mathrm{O}_{2}$ foi determinada em cerca de $160 \mu \mathrm{M}$.

Para avaliar a incidência do estado nutricional no possível envolvimento de Lprolina na resistência a estresse oxidativo, um segundo lote de experimentos foi 
realizado. Os epimastigotas $\left(30 \times 10^{6}\right.$ células $\left./ \mathrm{mL}\right)$ foram incubados durante 48 horas em meio contendo PBS+Prolina (3 mM), PBS+glutamato $(3 \mathrm{mM})$, PBS+Glicose $(3 \mathrm{mM}) \mathrm{e}$ somente PBS. Depois desse período, as células em diferentes condições foram contadas em câmara de Neubauer para iniciar o experimento com o mesmo número de células $\left(5 \times 10^{6}\right.$ células $\left./ \mathrm{mL}\right)$. Estas células foram então lavadas duas vezes com PBS por centrifugação e ressuspendidas em PBS suplementado ou não (controle) com $\mathrm{H}_{2} \mathrm{O}_{2}(160$ $\mu \mathrm{M}$ ) durante 12 horas a $28{ }^{\circ} \mathrm{C}$. Durante esse tempo, foram retiradas alíquotas a cada hora, com o mesmo número de células. Estas alíquotas foram lavadas duas vezes com PBS, e depois, ressuspensas em PBS e mantidas em placas de 96 poços para realização do ensaio de viabilidade com MTT. A morfologia e a viabilidade das células também foram monitoradas em microscópio ótico. A concentração de L-prolina intracelular livre foi medida pelo método de Bates (1973) antes e depois das células serem submetidas ao estresse oxidativo como descrito a seguir. Todos os ensaios de viabilidade com as diferentes culturas celulares foram realizados em triplicata.

\subsubsection{Ensaio de MTT}

A viabilidade de epimastigotas de T.cruzi foi estimada através do ensaio de MTT (3-(4,5-dimetiltiazol-2-il)-2,5 difenil bromotetrazolium), segundo Molinari et al. (2003). Em resumo, foram agregados a 100 ul das células ressuspensas em PBS, $30 \mu 1$ de MTT (5 $\mathrm{mg} / \mathrm{mL}$ ). Posteriormente as placas foram incubadas a $28^{\circ} \mathrm{C}$ durante 5 horas (sob proteção da luz). A reação foi interrompida com a adição de $100 \mu \mathrm{L}$ de SDS $10 \%$. A viabilidade das células foi observada mediante o aparecimento de uma cor azul de formazan homogêneo "thiazolidin", as placas foram deixadas até o dia seguinte. As leituras da absorbância foram feitas em um comprimento de onda de $595 \mathrm{~nm}$ usando como referência $690 \mathrm{~nm}$.

\subsubsection{Dosagem de prolina intracelular livre}

Os epimastigotas de $T$. cruzi e as leveduras $\left(5 \times 10^{6}\right.$ células $\left./ \mathrm{mL}\right)$ foram lavados duas vezes com PBS e lisadas como descrito no item 3.7. Os lisados foram centrifugados por 30 minutos a 10.000 x g a $4{ }^{\circ} \mathrm{C}$, e as proteínas precipitadas com 1 volume de TCA $20 \%$ (ácido tricloroacético) por 1 hora à temperatura ambiente. Após a incubação, o material foi centrifugado a $20.000 \mathrm{x}$ g por 30 minutos e o sobrenadante utilizado para dosagem do conteúdo intracelular de prolina livre. A quantificação de prolina intracelular livre foi realizada pelo método de Bates (1973). Nesses ensaios $200 \mu 1$ dos sobrenadantes foram incubados com $200 \mu 1$ de ácido acético e $200 \mu 1$ de uma solução ácida de ninidrina 
(0,25g ninidrina dissolvida em $6 \mathrm{ml}$ de ácido acético glacial e $4 \mathrm{ml}$ de ácido fosfórico 6 M) por 1 hora a $100{ }^{\circ} \mathrm{C}$. As reações foram paradas por incubação no gelo. $\mathrm{E}$ posteriormente submetidas à leitura das absorbâncias a $520 \mathrm{~nm}$. As reações foram feitas utilizando-se água destilada como branco. A concentração de prolina foi determinada a partir de uma curva padrão.

\subsection{Avaliação de análogos de prolina}

Diferentes análogos de prolina foram selecionados e avaliados como possíveis inibidores da via prolina-glutamato, são estes: o 3,4-Dehydro-DL-Proline; ácido (2S)azetidin-2-carboxílico; ácido L-pipecolinic e ácido (4R)-1,3-thiazolidin-4-carboxílico (T4C) (Figura 11). As curvas de crescimento utilizando as formas epimastigotas extracelulares de $T$. cruzi foram feitas na presença de diferentes concentrações dos análogos correspondentes, por absorbância como descrito a seguir.
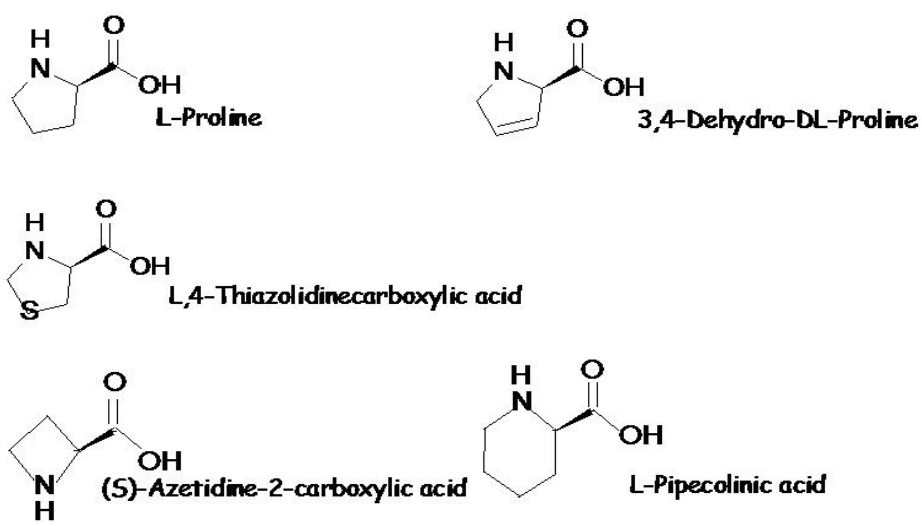

\section{Figura 11. Representação estrutural de prolina e seus análogos.}

\subsubsection{Ensaio de inibição do crescimento de epimastigotas de T.cruzi}

As formas epimastigotas de T. cruzi em fase de crescimento exponencial $\left(5 \times 10^{6}\right.$ células/mL) foram transferidas para placas de cultura de 96 poços $(200 \mu 1 /$ poço). Cada poço foi suplementado ou não (controles) com os análogos de prolina descritos acima (dissolvidos em PBS). As concentrações utilizadas variaram de $0,1 \mathrm{mM}$ a $100 \mathrm{mM}$, partindo de concentrações de uso já relatadas na literatura para cada um dos análogos para outros organismos. O crescimento celular foi estimado por leitura da absorbância em $620 \mathrm{~nm}$ durante dez dias. A absorbância foi transformada em valores de densidade celular (células/mL) usando uma equação de regressão linear previamente obtida sob as mesmas condições $\left(\mathrm{R}^{2}=0,9981, \mathrm{p}<0.05\right)$. Como controle positivo de inibição foi utilizada uma combinação de rotenona $(200 \mathrm{uM})$ e antimicina $(0,5 \mathrm{uM})$. A concentração de T4C que 
inibiu $50 \%$ do crescimento do parasito $\left(\mathrm{CI}_{50}\right)$ foi determinada em fase exponencial de crescimento ( $6^{\circ}$ dia) mediante ajuste dos dados da curva dose-resposta do T4C com a equação clássica sigmóide. Cada composto foi avaliado em octuplicata em cada experimento, sendo que os resultados apresentados correspondem a três experimentos independentes.

3.16.2 Efeito do análogo T4C na inibição do crescimento de epimastigotas de T. cruzi sob estresse oxidativo

Para avaliar o efeito do análogo T4C combinado ao estresse oxidativo, formas epimastigotas de $T$. cruzi em fase de crescimento exponencial $\left(5 \times 10^{6}\right.$ células $\left./ \mathrm{mL}\right)$ foram mantidas por 1 hora e 30 minutos a $28^{\circ} \mathrm{C}$ em PBS ou na presença de $80 \mu \mathrm{M}$ de $\mathrm{H}_{2} \mathrm{O}_{2}$ ( $\mathrm{CI}_{25}$ previamente estabelecida) com adição ou não de $0,25 \mathrm{mM}$ de T4C. As células foram coletadas por centrifugação e ressuspensas em meio LIT. Após 5 dias de recuperação, a viabilidade foi determinada pelo ensaio de MTT. Um segundo experimento comparativo foi realizado para avaliar o efeito protetor da L-prolina e a glicose (controle) na viabilidade do parasito sob estressse oxidativo na presença de T4C. Nesse experimento, $20 \times 10^{6}$ epimastigotas/mL foram lavados duas vezes em PBS e préincubados por 48 horas em PBS na presença ou ausência de $3 \mathrm{mM}$ de L-prolina e $3 \mathrm{mM}$ de glicose, com ou sem 0,25 mM de T4C. Depois da pré-incubação, as células foram lavadas duas vezes e ressuspensas em PBS com ou sem $80 \mu \mathrm{M} \mathrm{H}_{2} \mathrm{O}_{2}$ e mantidas sob essas condições a $28{ }^{\circ} \mathrm{C}$ por 3 horas. Após esse tempo, a viabilidade celular foi então estimada por MTT. Além disso, a morfologia e a viabilidade das células também foram monitoradas em microscópio ótico (contagem em câmara de Neubauer). A concentração de prolina interna livre foi medida em todas as condições e realizada como descrito por Bates (1973).

\subsection{Análises estatísticas}

Para analisar o sinergismo entre os dois tratamentos independentes $\left(\mathrm{H}_{2} \mathrm{O}_{2}\right.$ e T4C) o teste de ANOVA de duas vias foram realizados como descrito por Slinker et al., (1998). Nos demais ensaios o método ANOVA de uma via de acordo com o teste de Dunnet's foi usado nas análises estatísticas. Os valores de $\mathrm{p}<0,005$ foram considerados estatisticamente significantes.

\subsubsection{Atividade enzimática da PRODH/PR e transporte de prolina}

O ensaio de transporte de L-prolina foi realizado da seguinte forma: formas epimastigotas de $T$. cruzi em fase de crescimento exponencial (culturas de dois dias) 
foram lavadas três vezes com PBS por centrifugação e ressuspensas novamente em PBS, com densidade final de $20 \times 10^{7}$ células/mL e distribuídas em alíquotas de $100 \mu 1$ contendo $2 \times 10^{7}$ de células cada. $\mathrm{O}$ ensaio de transporte foi iniciado pela adição nos tubos de $100 \mu \mathrm{l}$ de prolina marcada radioativamente $(0,5 \mu \mathrm{Ci})$ a uma concentração final de $0,31 \mathrm{mM}$ ou 1,36 $\mathrm{mM}$ (valores correspondentes ao $\mathrm{Km}$ dos seus transportadores), suplementado ou não com $0,5 \mathrm{mM}$ de $\mathrm{T} 4 \mathrm{C}$. $\mathrm{A} \mathrm{V}_{0}$ foi medida a $28{ }^{\circ} \mathrm{C}$ por 30 segundos, e o transporte de prolina parado pela adição de $800 \mathrm{~mL}$ de prolina $50 \mathrm{mM}$ em PBS, e rapidamente lavada por centrifugação a $10.000 \mathrm{x}$ g, a $4{ }^{\circ} \mathrm{C}$ por 1 minuto. A atividade da enzima PRODH foi medida nos extratos como já descrito. A enzima prolina racemase (PR) foi medida em uma reação acoplada, usando D-prolina como substrato e o a atividade da PRODH como sistema revelador. Ambos os ensaios foram feitos na presença e ausência de 0,5 mM de T4C.

\subsection{Preparação de fração mitocondrial de $T$. cruzi}

As formas epismatigotas foram cultivadas em meio LIT-SFB até a fase exponencial de crescimento $\left(\sim 7 \times 10^{7}\right.$ células/mL). Os parasitos foram coletados por centrifugação a $1.000 \times$ g por 5 minutos a $4{ }^{\circ} \mathrm{C}$, descartado o sobrenadante, as células foram lavadas com o tampão A (fosfato de sódio $0,12 \mathrm{M} \mathrm{pH} \mathrm{8,0,} \mathrm{contendo} \mathrm{cloreto} \mathrm{de}$ sódio $86,3 \mathrm{mM}$ e glicose $56 \mathrm{mM}$ ) e novamente centrifugadas nas mesmas condições acima. O precipitado celular foi rompido por lise mecânica em cadinho de porcelana na presença de $80 \mu \mathrm{L}$ PMSF, $100 \mu \mathrm{L}$ de inibidor de protease (Sigma) utilizando-se pérolas de vidro. Depois de lisadas por aproximadamente 30 segundos, observou-se no microscópio a lise de pelo menos $90 \%$ das células. Posteriormente, adicionou-se ao precipitado $4 \mathrm{~mL}$ do tampão B (HEPES $50 \mathrm{mM}$ pH 7,2, sacarose 0,27 M, EDTA 1mM e

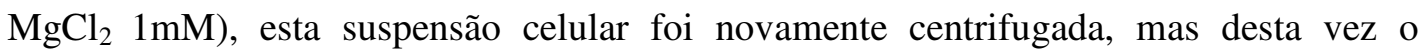
sobrenadante foi recuperado e o precipitado descartado. $\mathrm{O}$ sobrenadante foi centrifugado a 10.000 x $g$ por 10 minutos a $4{ }^{\circ} \mathrm{C}$, e o precipitado formado ressuspenso em $2 \mathrm{~mL} \mathrm{de}$ tampão C (Tampão fosfato de potássio $\mathrm{pH} 7,5$, sacarose $0,25 \mathrm{M}$ e EDTA $1 \mathrm{mM}$ ). Procedeu-se nova centrifugação a 10.000 x g por 10 minutos a $4{ }^{\circ} \mathrm{C}$, e finalmente o precipitado foi ressuspenso em $200 \mu \mathrm{L}$ de meio de reação $(125 \mathrm{mM}$ de sacarose, $65 \mathrm{mM}$ de $\mathrm{KCl}, 10 \mathrm{mM}$ de Hepes pH 7,2, $1 \mathrm{mM}$ de $\mathrm{MgCl}_{2}, 2 \mathrm{mM}$ de $\mathrm{KH}_{2} \mathrm{PO}_{4}$ e $0.5 \mathrm{mM}$ de EGTA) (Fernandes et al., 2010). A concentração de proteínas mitocondriais foi determinada pelo método de Bradford (1976). 


\subsection{Determinação da participação da PRODH no controle respiratório}

\subsubsection{Medida do consumo de oxigênio}

A medida do consumo de oxigênio com os substratos respiratórios para o complexo II (succinato) e prolina foi realizada em frações mitocondriais de epimastigotas de $T$. cruzi obtidas como descrito no item 3.17. A reação foi monitorada com um eletrodo de oxigênio de tipo Clark conectado a um oxígrafo Hansa Tech ${ }^{\circledR}$. Uma alíquota da suspensão mitocondrial $(0,5 \mathrm{mg} / \mathrm{mL}$ de proteína) foi adicionada ao meio de reação (volume final de $1 \mathrm{~mL}$ ) . O controle respiratório $(\mathrm{CR})$ foi determinado pela relação entre a velocidade respiratória antes da adição de ADP (basal), na presença de ADP (estado III) e a velocidade da respiração após adição de oligomicina (estado IV) (Vercesi et al., 1991).

3.18.2 Determinação do controle respiratório com succinato ou L-prolina como substratos para o complexo II da cadeia respiratória

A eficiência da cadeia respiratória mitocondrial de epimastigotas para oxidar prolina e succinato foi determinada com uma mistura de incubação (1 mL volume final) que continha: succinato $5 \mathrm{mM}$ ou prolina $5 \mathrm{mM}$, ADP $400 \mu \mathrm{M}$, oligomicina $2 \mu \mathrm{M}$ e 0,5 $\mathrm{mg} / \mathrm{mL}$ de fração mitocondrial (Rodrigues et al., 2001). 


\section{RESULTADOS}

\subsection{Clonagem da PRODH}

No banco de dados do Sanger Center (www.genedb.org), dois genes putativos que codificam para a PRODH de T. cruzi podem ser encontrados com os seguintes números sistemáticos, Tc00.1047053511237.30 e Tc00.1047053506411.30. Inicialmente optamos por trabalhar com o gene de número Tc00.1047053506411.30, pelo fato do outro apresentar características de um pseudogene. A sequiência nucleotídica do gene putativo da PRODH (Tc00.1047053506411.30) possui uma fase de leitura aberta de 1701 nucleotídeos que codifica uma seqüência de aminoácidos de 566 resíduos com massa molecular estimada de aproximadamente $64.7 \mathrm{kDa}$. A partir da seqüência desse gene, foram desenhados oligonucleotídeos (iniciadores) específicos, e utilizando-se DNA genômico de T. cruzi (cepa CL, clone 14) como molde, esse gene foi amplificado pela técnica de PCR. Após corrida eletroforética, foi possível observar uma banda única de aproximadamente $1.700 \mathrm{pb}$ correspondente ao tamanho esperado (Figura 12A). Essa banda foi purificada e clonada diretamente no vetor pGEM-T $^{\circledR}$ (Figura 12B). A construção resultante foi utilizada para transformar bactérias competentes. A partir de colônias bacterianas transformantes fizeram-se culturas das quais se obtiveram preparações plasmídicas que foram utilizadas para confirmar a identidade do fragmento de DNA clonado por seqüenciamento. Posteriormente, esse DNA recombinante foi utilizado nos demais procedimentos de subclonagem. 
A

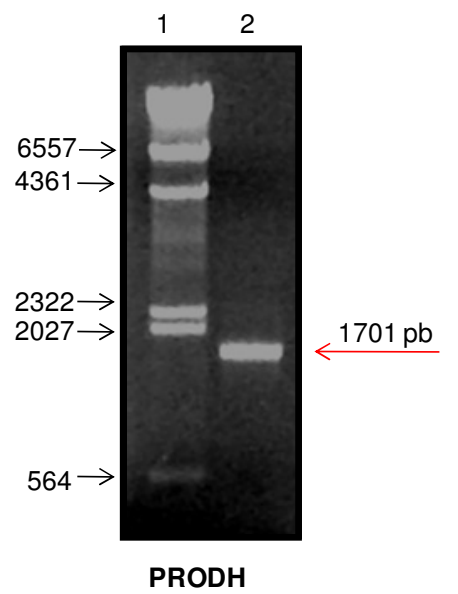

B

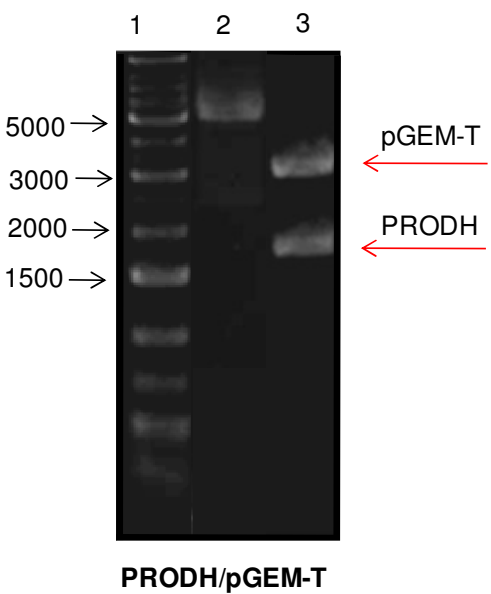

Figura 12. Amplificação da fase aberta de leitura (ORF) do gene PRODH de T. cruzi e clonagem em vetor pGEM-T. (A) O produto de amplificação do gene PRODH (1701 pb), obtido por PCR a partir do DNA genômico de T. cruzi é observado na canaleta 2 . (B) $\mathrm{O}$ fragmento de aproximadamente $5000 \mathrm{pb}$ observado na canaleta 2 corresponde à construção PRODH/pGEM-T. Na canaleta 3, observam-se duas bandas, obtidas após digestão da construção PRODH/pGEM-T com enzimas de restrição apropriadas, referentes ao vetor pGEM-T (3015 pb) e ao inserto PRODH (1701 pb). Em ambos os géis, o marcador de peso molecular é mostrado na canaleta 1. 


\subsection{Análises in silico}

A comparação por alinhamento global da seqüência de aminoácidos da PRODH de T. cruzi (Tc00.1047053506411.30) com as PRODHs de outras espécies através do programa Clustal W (versão 1.82) mostrou que a enzima de T. cruzi possui uma porcentagem de identidade de $54 \%$ com a correspondente de Leishmania major (Lmj F26.1610), 31\% com a de Homo sapiens (AAD24775), com a de 39\% Arabidopsis thaliana (AAB40615) e 25\% com a de Sacharomyces cerevisiae (YLR142W-AY69290). Como esperado, a proteína com função conhecida que apresenta maior porcentagem de identidade ( $72 \%$ de identidade) é a prolina desidrogenase de T. brucei (Tb927.7.210) (Figura 13).

A prolina desidrogenase de E. coli (ADE88724) (que possui $25 \%$ de identidade com a enzima correspondente de $T$. cruzi) já havia sido cristalizada, e os resíduos de aminoácidos envolvidos na ligação com o substrato e com o cofator estão bem identificados. Na estrutura dessa enzima, os resíduos dos aminoácidos Asp ${ }^{370,}$ Leu $^{513}$, $\mathrm{Tyr}^{540}, \operatorname{Arg}^{555}, \operatorname{Arg}^{556}$ e Glu ${ }^{559}$ estão envolvidos na ligação e estabilização do cofator FAD, sendo que a $\operatorname{Arg}^{431}$ possui papel essencial nessa interação. Já os resíduos $\operatorname{Asp}^{370}$, $\mathrm{Leu}^{513}$ e $\mathrm{Tyr}^{540}$ foram descritos como responsáveis pela ligação da proteína ao substrato (prolina) (Lee et al., 2003). Em estudos recentes verificou-se que esses aminoácidos estão conservados na enzima de T. brucei (LAMOUR et al., 2005) e em PUT 1 p (PRODH) de S. cerevisiae (WANDURAGALA et al., 2010). Nossa análise mostra que os mesmos aminoácidos também estão conservados em T. cruzi (Figura 13). 
TbPRODH : EAEAEGEAPSPGIAEAPNLSMASLVNNNTSV TCPRODH : EADVAGEAPPPGLEEAPNLSMASLVHKTTVM LmPRODH : EADTEGFAPEPGVASGPDISMSSLVMKPNVQ HSPRODH : YQAHRAFG---------DRRNGVISARTY
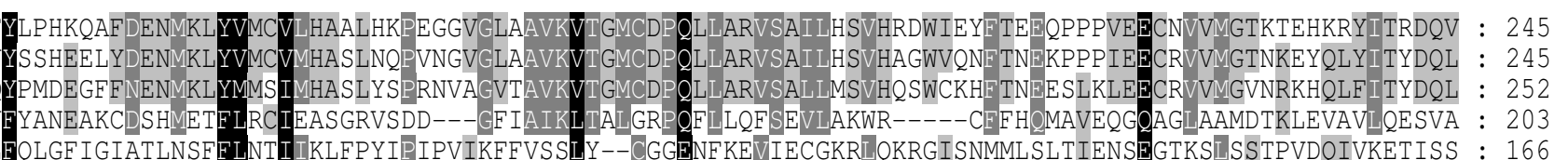

SCPRODH : INFLQTLP -KKELFQLGFIGIATLNSE

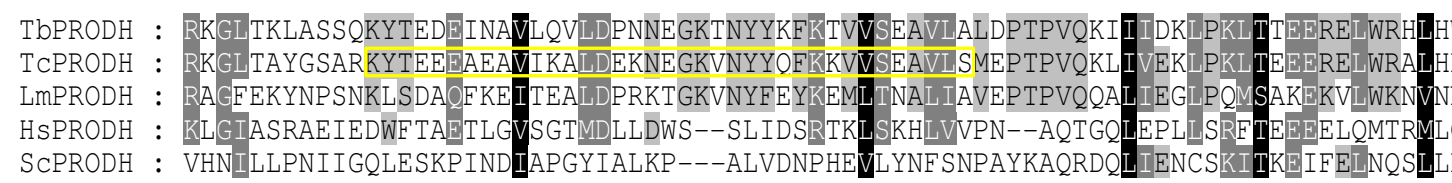

SCPRODH : VHNILLPNIIGQLESKPIND

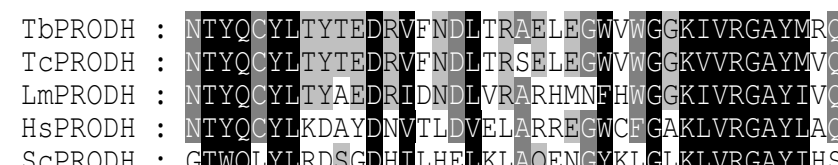

HSPR

SCPRODH
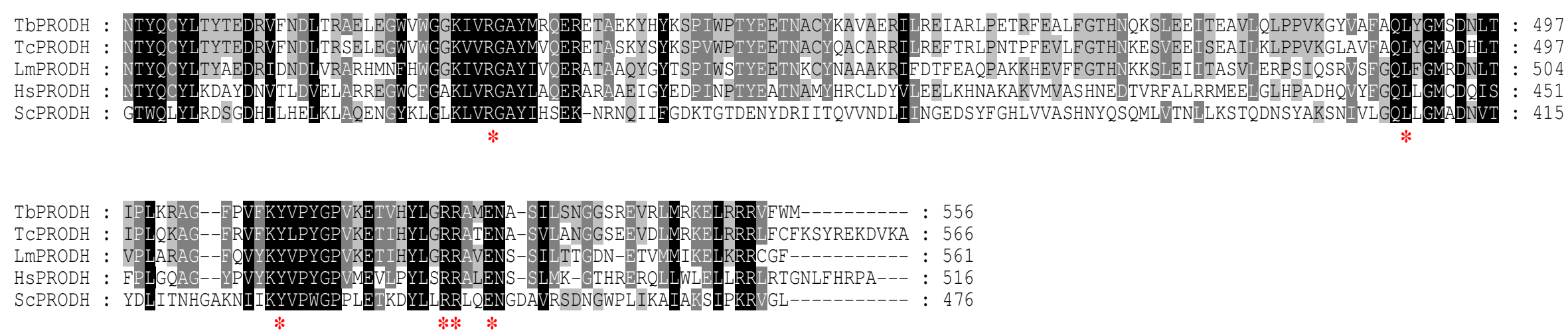

Figura 13. Alinhamento das sequiências de aminoácidos da PRODH de T. cruzi e os seus correspondentes ortólogos em T. brucei, $L$. major, H. sapiens e S. cerevisiae. A sequiência responsável pelo endereçamento mitocondrial está destacada no quadro vermelho, enquanto que o domínio EF-hand 2 aparece delimitado pelo quadro amarelo. Os aminoácidos $\mathrm{Asp}^{346}, \mathrm{Leu}^{491}, \mathrm{Tyr}^{511}, \mathrm{Arg}^{525}, \mathrm{Arg}^{526}$, $\mathrm{Glu}^{528} \mathrm{e} \mathrm{Arg}^{408}$ (indicados com asterisco) na sequiência de T. cruzi estão envolvidos na ligação ao cofator e ao substrato. O alinhamento foi gerado usando o programa Clustal W.

Fonte: Higgins et al. (1996). 
A presença de domínios ou motivos protéicos putativos conservados entre as seqüências das diferentes espécies foi analisada mediante a utilização da base de dados do InterProscan (versão 4.6) (EMBL-EBI). Esta análise resultou na detecção de domínios relacionados com a família das prolina desidrogenases (também chamada de prolina oxidase) e um domínio de ligação à FAD. Surpreendentemente, nessa análise também foi encontrado um domínio EF-hand putativo de ligação a $\mathrm{Ca}^{2+}{\mathrm{ou} \mathrm{Mg}^{2+}}_{\text {(Figura 14). }}$

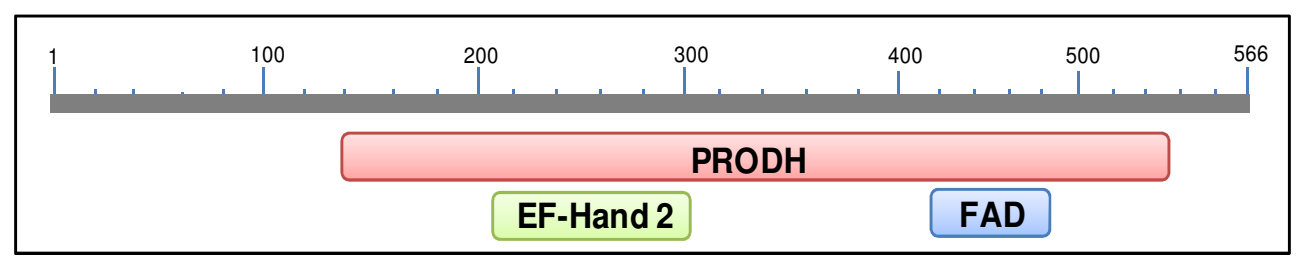

Figura 14. Representação esquemática dos domínios protéicos presentes na PRODH de T. cruzi. Os domínios representados na figura foram detectados por comparação da sequência contra a base de dados do programa InterProscan. PRODH é um domínio encontrado na enzima prolina desidrogenase, também conhecida como prolina oxidase (POX). O domínio de ligação ao cofator FAD, assim como o domínio envolvido na ligação ao íon $\mathrm{Ca}^{2+}$ ou $\mathrm{Mg}^{2+}(E F$-hand 2$)$ também estão representados. 
$\mathrm{Na}$ literatura tem sido descrito que o domínio EF-hand possui seis resíduos de aminoácidos que estão envolvidos diretamente na ligação ao cátion. Estes resíduos encontram-se na posição 1, 3, 5, 7, 9 e 12, e também são denominados por X, Y, Z, -X, Y e - Z. Além disso, aminoácidos negativos nas posições $1(\mathrm{X}), 3(\mathrm{Y})$ e $12(\mathrm{Z})$ são comuns em diferentes tipos de EF-hand, e a sexta posição deste conjunto de aminoácidos é ocupada, na maioria dos casos, por um resíduo de glicina (KAWASAKI; KRETSINGER, 1994). Como destacado na Figura 15, o provável domínio EF-hand de T. cruzi possui resíduos de aminoácidos bastante conservados quando comparados com domínios EFhand já caracterizados em proteínas de T. cruzi e outros organismos.

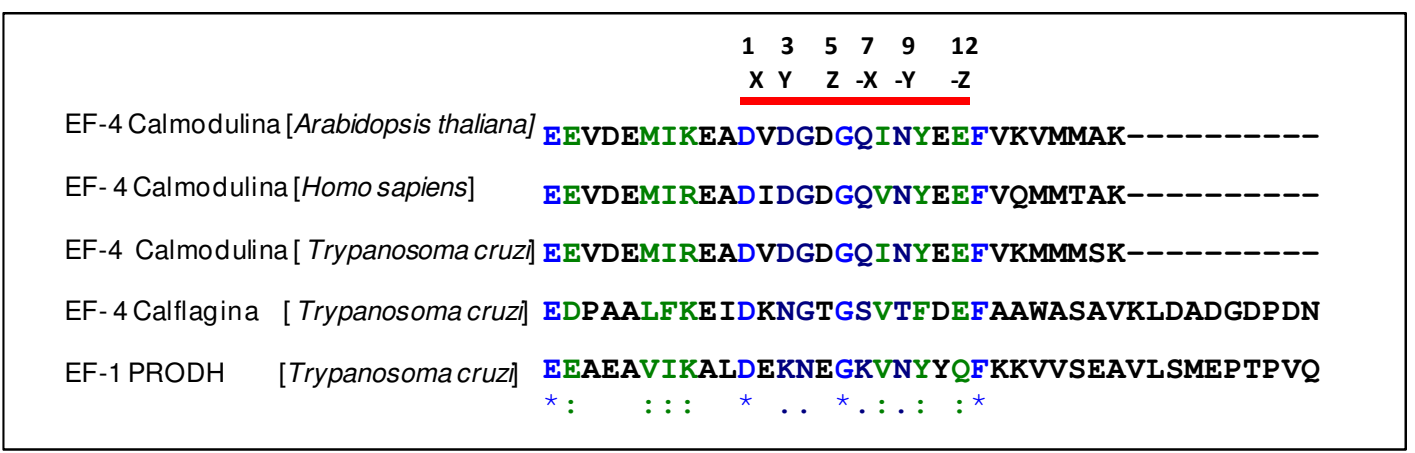

Figura 15. Análise do domínio $E F$-hand presente na PRODH de $T$. cruzi. O domínio EFhand 2 da PRODH de T. cruzi foi comparado aos domínios EF-hand 4 de calmodulina de $A$. thaliana, $H$. sapiens e $T$. cruzi e também com aquele presente em calflagina (proteína flagelar ligante de $\left.\mathrm{Ca}^{2+}\right)$ de $T$. cruzi. Os números $(1,3,5,7,9$ e 12) e as letras ( $\mathrm{x}, \mathrm{y}, \mathrm{z},-\mathrm{x},-\mathrm{y}$ e -z) indicam os resíduos que se ligam diretamente ao íon $\mathrm{Ca}^{2+}$. Os símbolos (*), (:) e (.) indicam resíduos idênticos, altamente conservados e pouco conservados entre as seqüências, respectivamente. 
Nas análises da sequiência de aminoácidos através de programas de predição de localização celular (MitoProt II v. 1.101, PSORT v. 6.4, TargetP v.1.1, Predotar v.1.03) também foi identificada, na PRODH de $T$. cruzi, uma região de sinalização para direcionamento mitocondrial. Segundo o programa MitoProt II, essa região encontra-se na porção N-terminal, possui aproximadamente 29 resíduos de aminoácidos e apresenta 97\% de probabilidade para localização mitocondrial, além de possuir um sítio de clivagem possivelmente entre os resíduos $\mathrm{Asp}^{16} \mathrm{e} \mathrm{Val}^{17}$ (Figura 16).

Os índices de hidropaticidade para a seqüência em estudo também foram preditos através do programa ProtScale (WALKER, 2005) de acordo com a escala de Kyte e Doolittle (1982). Os resultados mostraram um grande número de aminoácidos polares e hidrofóbicos, indicando que a PRODH pode ser uma proteína de membrana. Além disso, a análise da PRODH pelo programa TMPRED (HOFMANN; STOFFEL, 1993) sugeriu a presença de três hélices de transmembrana, uma de 28 resíduos de aminoácidos na posição 38-65, outra de 20 resíduos na posição 71-90 e a última de 26 resíduos na posição 167-192. Os comprimentos dessas hélices são compatíveis com aqueles necessários para cruzar a membrana mitocondrial.

Figura 16. Região de sinalização mitocondrial da proteína PRODH de $T$. cruzi predita através do programa Mitoprot II. A seqüência de direcionamento mitocondrial, localizada na porção N-terminal da proteína PRODH, possui 29 resíduos de aminoácidos. A região destacada em negrito apresenta-se como uma fita- $\beta$ (amarelo) e uma $\alpha$ - hélice (rosa), sendo predito um sítio de clivagem na região indicada pela seta vermelha. A predição das estruturas secundárias foi obtida através do programa PSIPRED.

Fonte: Mcguffin et al. (2000). 


\subsection{Complementação da PRODH em $S$. cerevisiae}

Para verificar se o gene PRODH de T. cruzi codifica uma enzima funcional, foi avaliada a sua capacidade de complementar uma cepa de $S$. cerevisiae mutante para o gene PUT1 (ortólogo). A cepa YLR $142 \mathrm{~W}(\triangle P U T 1)$ mutante para o gene PRODH foi selecionada e obtida da coleção do banco da EUROSCARF (EUROpean Saccharomyces Cerevisiae ARchive for Functinal Analysis) (a cepa foi cedida gentilmente para este trabalho pelo Prof $^{\circ}$ Dr. Luiz Eduardo Soares Neto-ICB-USP).

O gene PRODH de $T$. cruzi foi subclonado em vetor de expressão de leveduras (pYES 2.0) e a positividade dos clones obtidos foi verificada por reação de digestão com as enzimas de restrição específicas utilizadas na construção (Figura 17). Na escolha do vetor de expressão e da cepa de levedura mutante, algumas características foram consideradas para auxiliar o processo de seleção das colônias transformadas. Uma delas é o fato dessa linhagem mutante possuir auxotrofia para uracila que é complementada pelo gene URA3 presente no vetor escolhido. Tal característica pode ser utilizada como marcadora de seleção das leveduras transformadas com esse plasmídeo. Além disso, em condições normais de crescimento, a cepa de levedura escolhida não é capaz de crescer quando a prolina é disponibilizada como única fonte de nitrogênio. Adicionalmente, o vetor de expressão pYES possui um sítio de policlonagem à jusante de um promotor $G A L 1$, o qual pode regular positivamente a expressão do gene clonado (neste caso PRODH) na presença de galactose. 


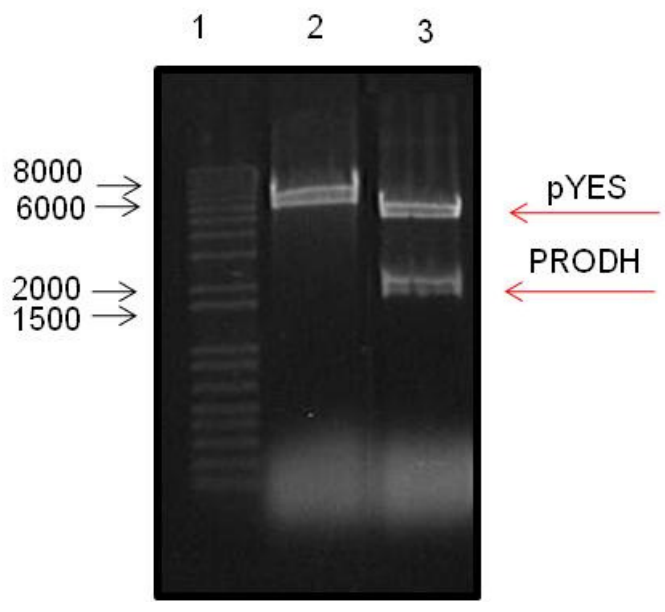

Figura 17. Clonagem do gene PRODH de T. cruzi em vetor pYES. O produto de amplificação do gene PRODH (1701 pb), obtido por PCR a partir do DNA genômico de T. cruzi, foi clonado no vetor pYES (5900 pb), gerando uma construção de aproximadamente $8000 \mathrm{pb}$, a qual pode ser observada na canaleta 2. Na canaleta 3, observam-se duas bandas, obtidas após digestão com enzimas de restrições apropriadas, referentes ao vetor pYES e ao inserto PRODH clonado. O marcador de peso molecular é mostrado na canaleta 1.

A levedura mutante ( $\triangle P U T 1)$ foi transformada com a construção PRODH/pYES e também com o vetor pYES sem inserto (controle). A seleção das colônias transformadas foi realizada utilizando meio mínimo sem uracila e com galactose $\left(\mathrm{SD}^{-\mathrm{Ura}} \mathrm{e}\right.$ Gal 2\%). Através da análise fenotípica dos clones obtidos, observamos que somente a levedura complementada com o gene PRODH de T. cruzi foi capaz de crescer em meio de cultura contendo somente L-prolina como fonte de nitrogênio (Figura 18A e B). Os resultados obtidos demonstram que o produto desse gene é capaz de oxidar prolina a P5C e subseqüentemente a glutamato. Além disso, o nitrogênio proveniente da prolina pode ser utilizado para a síntese de outros componentes nitrogenados na cepa de levedura utilizada. 


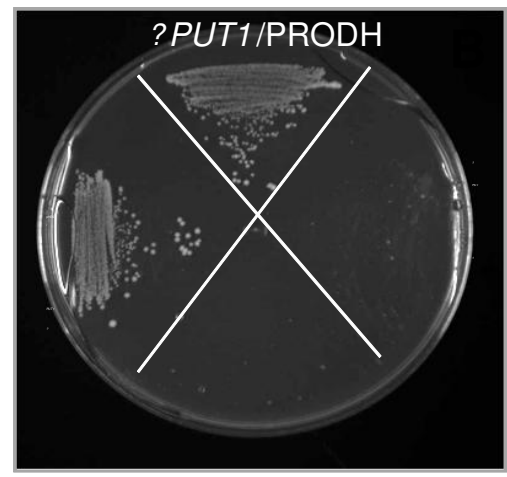

$\mathrm{SD}^{-\mathrm{URA} G a \mathrm{l}}$

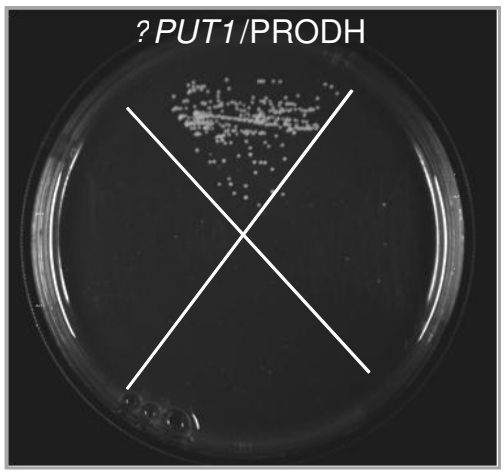

$\mathrm{SD}^{+\mathrm{PRO}} \mathrm{Gal}$
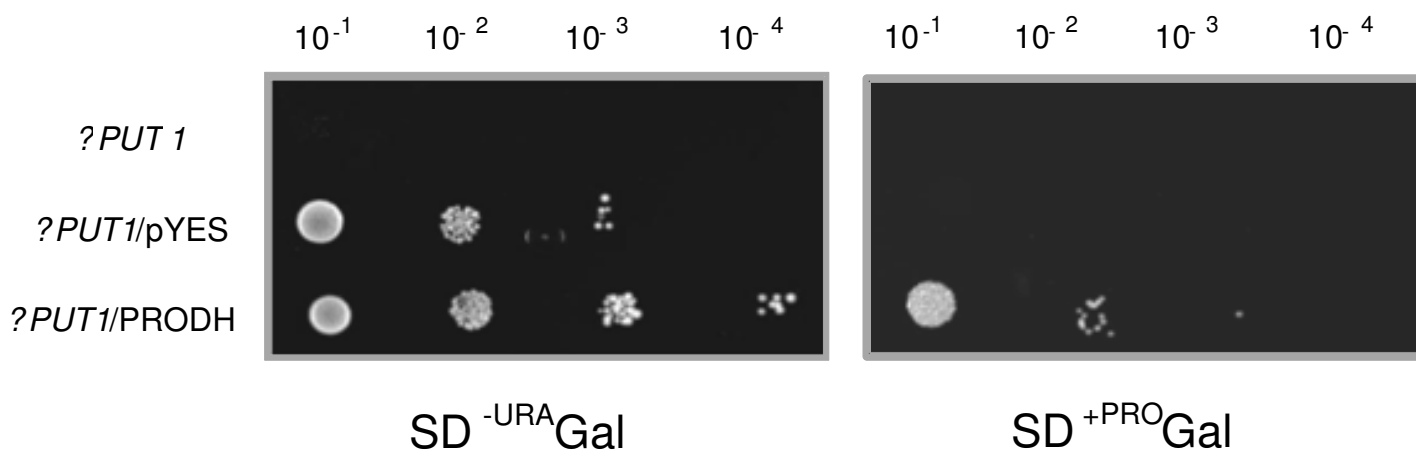

Figura 18. Complementação funcional de $S$. cerevisiae com o gene de PRODH de $T$. cruzi. As leveduras mutante $(\triangle P U T 1)$, controle $(\triangle P U T 1 / \mathrm{pYES})$ e complementada $(\triangle P U T 1 / \mathrm{PRODH})$ foram selecionadas em meio de cultura com vários aminoácidos com exceção de prolina e uracila ( $\left.\mathrm{SD}^{-\mathrm{URA}} \mathrm{Gal}\right)$, e em meio de cultura suplementados com L-prolina como fonte de nitrogênio $\left(\mathrm{SD}^{+\mathrm{PRO}} \mathrm{Gal}\right)$. De acordo com as condições de crescimento descritas acima, as leveduras foram plaqueadas por estriação (A) e também por diluição em série $\left(10^{-1}\right.$ a $\left.10^{-4}\right)(\mathbf{B})$. Em ambos os casos, as placas foram incubadas a $30^{\circ} \mathrm{C}$ por 3 a 4 dias. 
Com o objetivo de verificar a presença do RNAm específico e da proteína codificada pelo gene PRODH na levedura complementada, foram realizados experimentos de RT-PCR e de Western Blotting, respectivamente. A análise da levedura complementada por RT-PCR mostrou a presença de um produto de amplificação de tamanho compatível com aquele esperado para o mRNA de T. cruzi, aproximadamente 1,7 kb (Figura 19A). Com o intuito de avaliar a expressão da PRODH de T. cruzi na levedura complementada, foi obtido um anticorpo específico contra um peptídeo sintético desenhado entre a região $\operatorname{Tyr}^{380}$ e $\mathrm{Glu}^{395}$ da PRODH de T. cruzi. A especificidade do anticorpo anti-PRODH foi confirmada por ensaios da competição da PRODH recombinante com o anticorpo e o peptídeo livre (dado não mostrado). Esse anticorpo foi capaz de reconhecer, em ensaios de western blotting, um antígeno de $T$. cruzi que migra eletroforeticamente como uma única banda de peso molecular aparente de $65 \mathrm{kDa}$, tanto em extrato total de epimastigotas quanto em extrato das leveduras complementadas com pYES/PRODH. Esse peso molecular é compatível com o predito in silico para a PRODH de T. cruzi. 


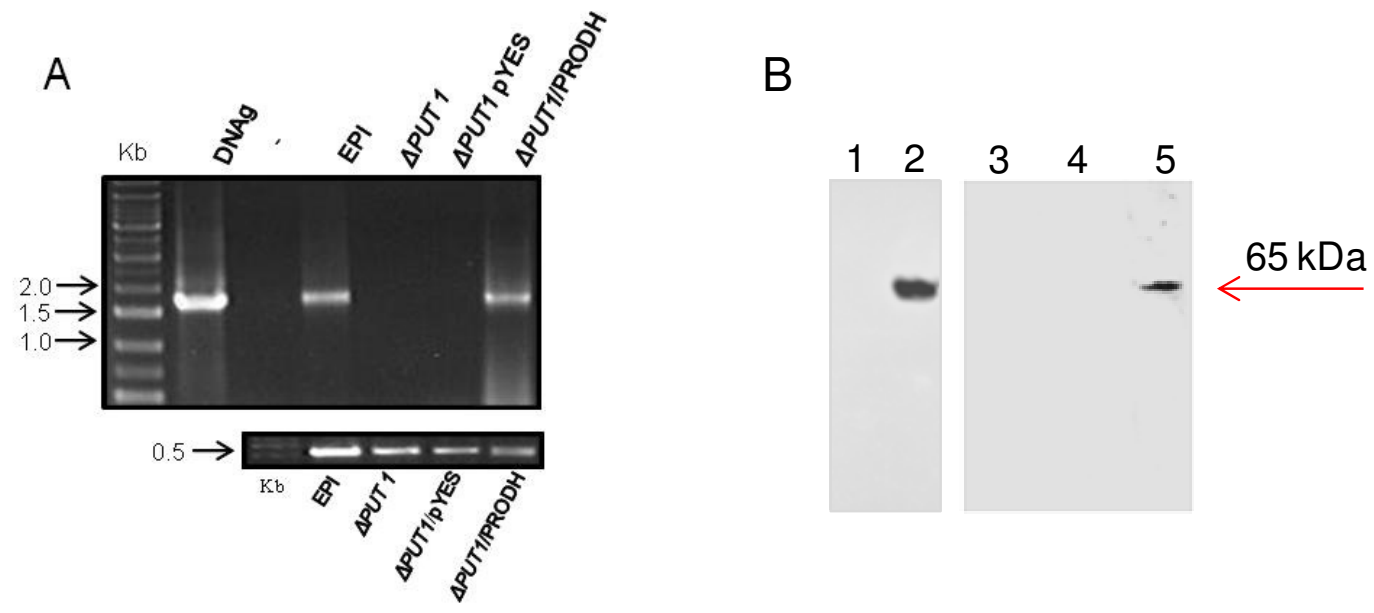

Figura 19. Perfil de transcrição do gene de PRODH de T.cruzi por RT-PCR $_{\text {semi-quantitativo }}$ e análise da proteína PRODH por Western Blotting. (A) O gel mostra os produtos de PCR amplificados a partir de cDNAs obtidos por transcrição reversa dos RNAs mensageiros das formas epimastigotas de T. cruzi (Nepi, Von Aderkas et al.), e das leveduras mutante $(\triangle P U T 1)$, controle $(\triangle P U T 1 / \mathrm{pYES})$ e complementada $(\triangle P U T 1 / \mathrm{PRODH})$. Os controles positivos e negativos do ensaio correspondem às reações realizadas com DNA genômico de $T$. cruzi (gDNA) ou não (-), respectivamente. O gene GAPDH foi usado como controle (in-house keeping) das amostras na reação de PCR. (B) As membranas contendo extrato total de epimastigotas de $T$. cruzi foram incubadas com o soro pré-imune (controle) como mostrado na canaleta 1 , e com o soro anti-PRODH, como mostrado na canaleta 2. Membranas com os extratos protéicos das leveduras mutante ( $\triangle P U T 1)$, controle $(\triangle P U T 1 / \mathrm{pYES})$ e complementada ( $\triangle P U T 1 / \mathrm{PRODH})$ correspondem às canaletas 3,4 , e 5, respectivamente. A seta indica a banda de PRODH, com a massa molecular esperada de aproximadamente $65 \mathrm{kDa}$. 
Finalmente, para confirmar a associação do fenótipo da levedura com o gene de interesse foram realizados ensaios de atividade enzimática para PRODH (Figura 20). Foi observado que o extrato da levedura complementada apresenta atividade específica maior do que o da levedura selvagem, da qual a mutante foi derivada (cepa BY4741), ou extratos de epimastigotas de T. cruzi. Como esperado, o ensaio dessa enzima em extratos das leveduras mutante $(\triangle P U T 1)$ e controle $(\triangle P U T 1 / \mathrm{pYES})$ tiveram baixa atividade. Essa atividade basal deve-se ao fato de que, possivelmente, nas condições testadas, ocorre reação inespecífica com outras oxirredutases.

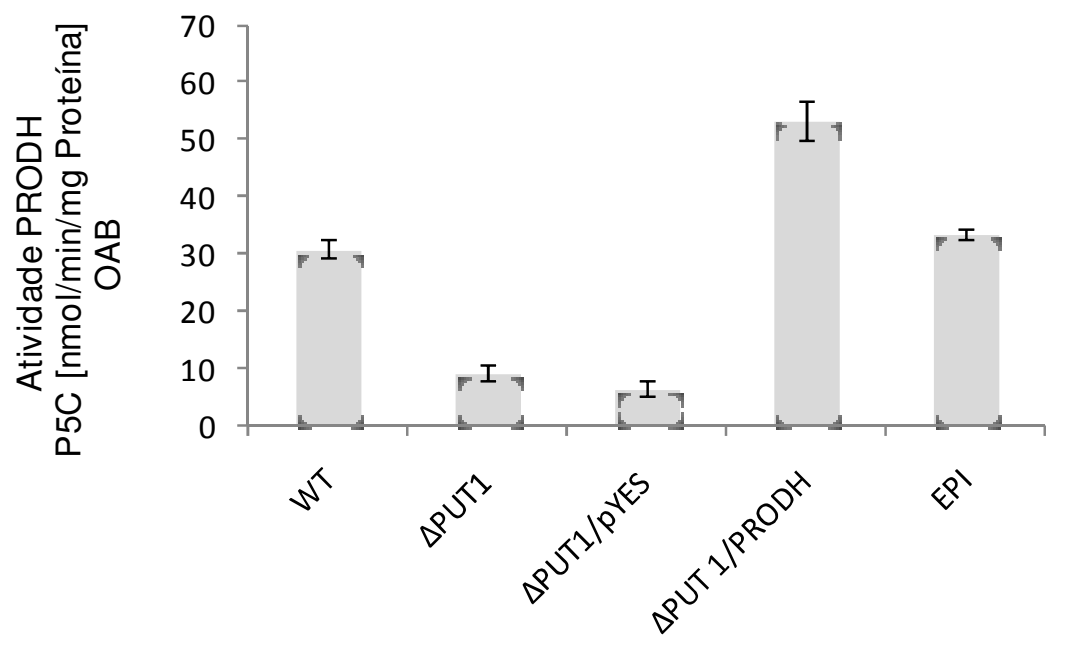

Figura 20. Ensaio de atividade da enzima PRODH. As leveduras mutante $(\triangle P U T 1)$, controle ( $\triangle P U T 1 / \mathrm{pYES}$ ),WT (cepa selvagem BY4741 que deu origem a mutante $\triangle P U T 1$ ) e complementada ( $\triangle P U T 1 / \mathrm{PRODH})$ foram crescidas por 16 horas a $30^{\circ} \mathrm{C}$ em meio mínimo com prolina Os epimastigotas de $T$. cruzi foram cultivados em meio LIT. Posteriormente, a atividade enzimática de PRODH com extratos protéicos de todas as amostras acima foram realizadas através de ensaios de oxirredução (OAB). Os resultados correspondem à média de três experimentos independentes. 


\subsection{Análise do perfil transcricional da PRODH ao longo do ciclo de vida do $T$. cruzi}

Um dos interesses do presente trabalho é analisar a regulação do metabolismo de prolina ao longo do ciclo de vida do parasito. Trabalhos anteriores relatam que o metabolismo de prolina é fundamental na metaciclogênese (CONTRERAS et al., 1985) e na progressão do ciclo intracelular do parasito, particularmente no processo de diferenciação de epimastigotas intracelulares para tripomastigotas. Sabe-se ainda que há uma relação entre o transporte de prolina, a disponibilidade desse aminoácido no meio extracelular (citoplasma da célula hospedeira), e o processo de diferenciação (TONELLI et al., 2004). A quantificação do RNAm da enzima PRODH foi realizada por RTPCR $_{\text {quantitativo }}$ (RT-PCRq). Observou-se que o perfil de expressão da enzima varia ao longo do ciclo de vida de T.cruzi, sendo a forma epimastigota intracelular a que possui a maior quantidade de RNAm, e o estágio amastigota os menores níveis do transcrito (Figura 21A). As demais formas do ciclo de vida de T. cruzi possuem um padrão de transcrição similar. Quando foi analisado o nível protéico da PRODH por western blotting observou-se que a banda que corresponde ao peso molecular esperado para PRODH foi detectada também com maior intensidade na forma epimastigota intracelular e com menor intensidade nas formas epimastigota extracelular, tripomastigota metacíclico e tripomastigota de cultura. Na forma amastigota, a banda foi indetectável, assim como no controle negativo (células $\mathrm{CHO}$ ). Como sistema de normalização, foi utilizado um anticorpo contra a proteína GAPDH, como previamente descrito (SILBER et al., 2009). O perfil apresentado no western blotting é compatível com o observado pela quantificação do RNAm no ensaio de RT-PCR quantitativo (Figura 21B). 


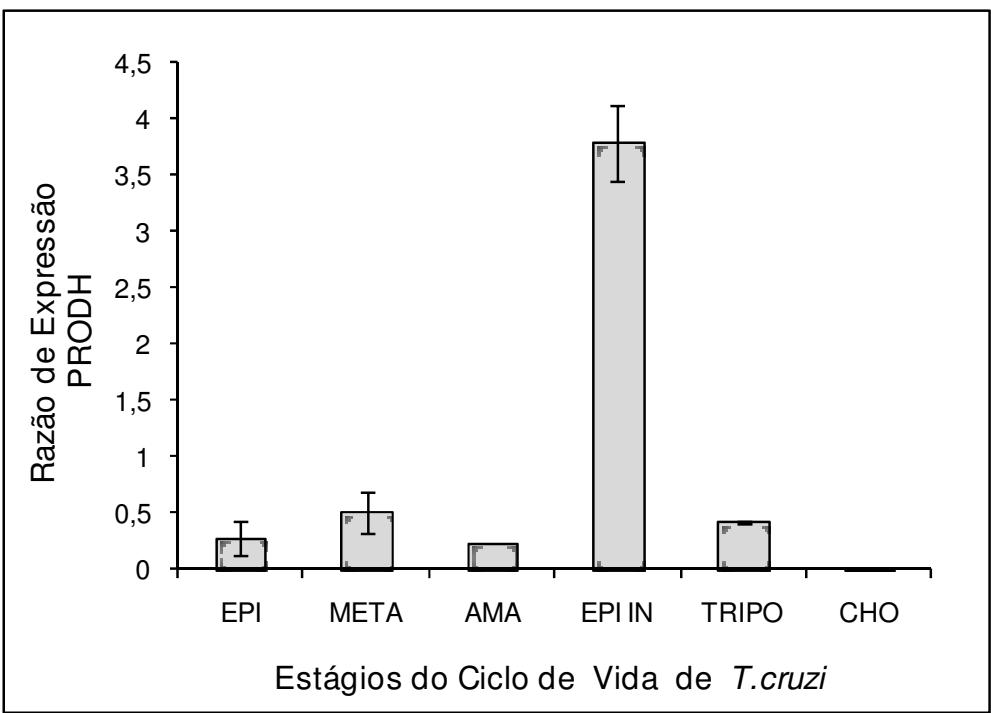

A

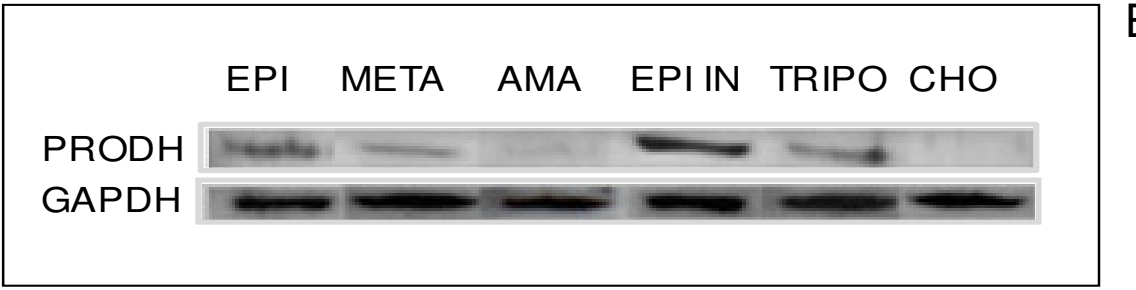

Figura 21. Perfís transcricional e traducional do gene PRODH ao longo do ciclo de vida de T. cruzi. Ensaio de RT-PCRquantitativo (A) e western blotting (B). As amostras correspondem a todos os estágios presentes ao longo do ciclo de vida do T. cruzi. Epimastigotas (Nepi, Von Aderkas et al.), tripomastigotas metaciclícos (META), amastigotas (AMA), epimastigotas intracelulares (EPI IN), tripomastigotas de cultura (TRIPO). As células hospedeiras $\mathrm{CHO}_{1}(\mathrm{CHO})$ foram utilizadas como controle positivo nos experimentos acima. Os resultados mostrados na figura A representam a média dos valores obtidos de três amostras biológicas independentes. 


\subsection{Localização Subcelular da PRODH}

A maior parte dos aminoácidos em T. cruzi é metabolizada via Ciclo de Krebs e as enzimas correspondentes ao seu metabolismo estão localizadas majoritariamente na matriz ou na face interna da membrana interna mitocondrial. Neste sentido, a localização subcelular da PRODH pode ser relevante para inferir possíveis funções relacionadas ao metabolismo energético.

Como já relatado através de análises da seqüência de aminoácidos, observamos que a PRODH possui uma região com características de direcionamento mitocondrial. Através de ensaios de microscopia de imunofluorêscencia, utilizando o anticorpo antiPRODH obtido neste trabalho e também um marcador mitocondrial (MitoTracker), observou-se que em todos os estágios do ciclo de vida de T. cruzi a PRODH apresentou um perfil de localização mitocondrial, o qual foi evidenciado pela sobreposição da fluorescência correspondente ao marcador mitocondrial e a fluorescência correspondente ao anticorpo específico (Figura 22). Como mencionado anteriormente, a especificidade do anticorpo anti-PRODH foi avaliada por Western-blotting. Adicionalmente, ensaios de imunofluorescência na presença ou ausência do peptídeo livre que foi utilizado como antígeno na geração do anticorpo confirmou a especificidade desse soro (dados não mostrados).

Para validar a distribuição subcelular da enzima PRODH em T. cruzi como observado nos ensaios anteriores, foi realizado um ensaio de permeabilização seletiva de epimastigotas de T. cruzi com digitonina. Este ensaio é baseado no fato de que diferentes conteúdos de esteróis das membranas celulares fazem estas sensíveis a diferentes concentrações de digitonina. A digitonina é um esterol glicosilado que se liga a 3- $\beta$ hidroxiesteróis não esterificados (predominantemente o colesterol) para formar $\mathrm{o}$ complexo digitonina-esterol. Esse complexo produz alterações na membrana plasmática tornando-a permeável. Assim, a membrana plasmática, com alto conteúdo de esteróis é especificamente permeabilizada a baixas concentrações do detergente digitonina, e altas concentrações são requeridas para permeabilizar as membranas glicossomal e mitocondrial. O perfil de extração da atividade da PRODH foi comparado com alguns marcadores enzimáticos, como a enzima piruvato quinase (PK), hexoquinase (HK) e citrato sintase (Figura 23A). As enzimas PK e HK são enzimas envolvidas no metabolismo de glicose, porém a PK localiza-se no citoplasma e a HK no glicossomo (CAZZULO, 1994; CACERES et al., 2003). A CS participa do ciclo do ácido cítrico na 
matriz mitocondrial (JUAN et al., 1977). Na concentração de digitonina $0,1 \mathrm{mg} / \mathrm{mL}$, cerca de $76 \%$ de extração (atividade) do marcador citosólico (PK) foi obtido, enquanto que somente $30 \%$ de atividade da PRODH foi medida nessa mesma condição. Contudo, nas concentrações iniciais de digitonina $(0,1 \mathrm{mg} / \mathrm{mL})$, os marcadores mitocondrial e glicossomal (HK) já começam a ser liberados e a atividade PRODH detectada (Figura 23 A). Cerca de $80 \%$ da PRODH está insolúvel e $20 \%$ solúvel de acordo com o marcador mitocondrial e citosólico, o que sugere a possibilidade da PRODH estar associada à mitocôndria (Figura 23B). 


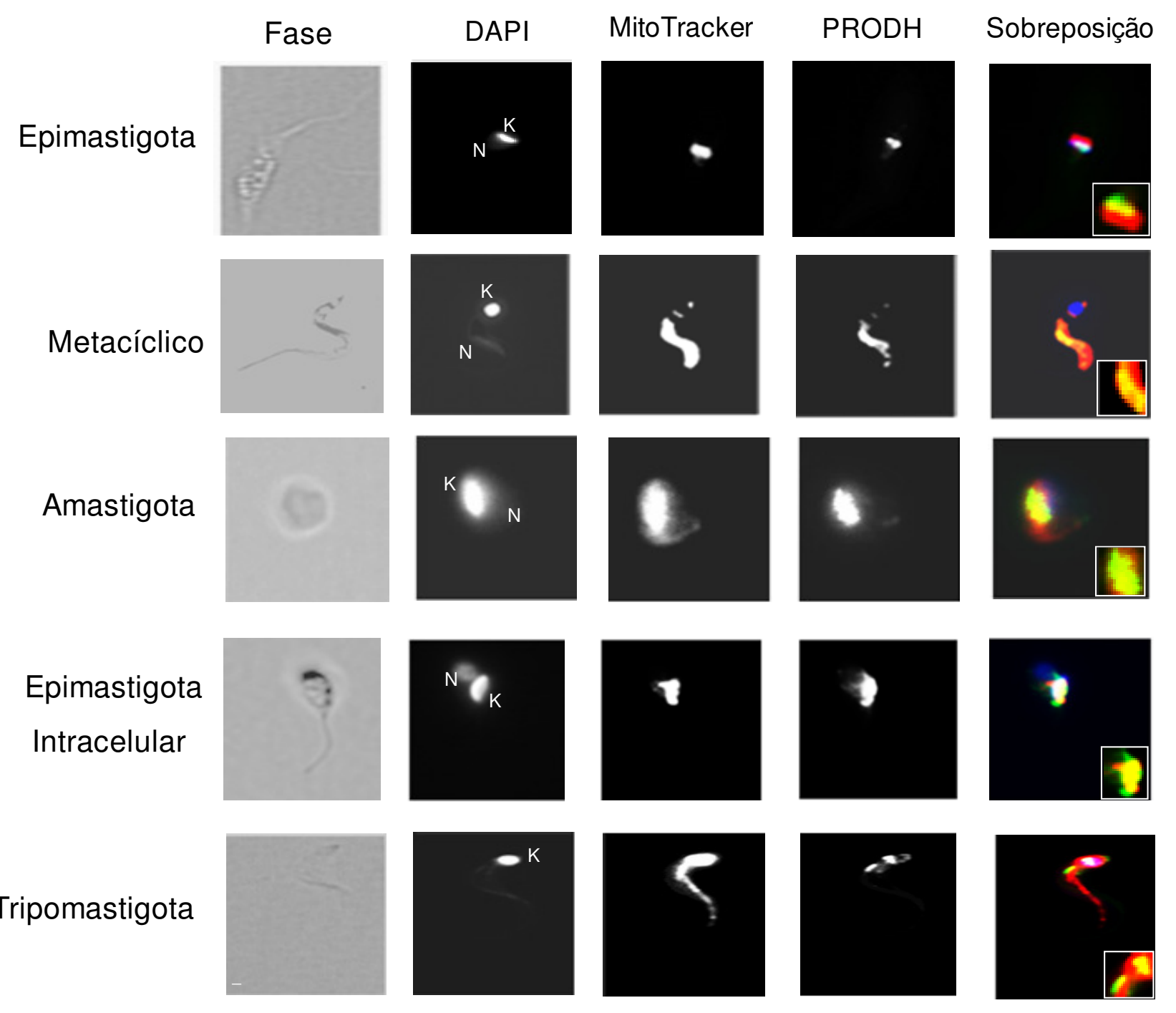

Figura 22. Ensaio de microscopia de imunofluorêscencia de todos os estágios do ciclo de vida do $T$. cruzi. Foram utilizados o marcador mitocondrial MitoTracker® Red CMXRos (100 nM), em vermelho. DAPI, em azul, como marcador do cinetoplasto $(\mathrm{K})$ e núcleo $(\mathrm{N})$ e o anticorpo policlonal anti-PRODH, em verde. O quadro menor à direita destaca a imunolocalização da proteína na mitocôndria (amarelo). Barra indica $2 \mu \mathrm{m}$. 
O perfil de extração das diferentes frações obtidas também foi monitorado por análise de Western Blotting. Como observado na Figura 23B, houve um reconhecimento específico do anticorpo anti-PRODH em todas as frações insolúveis $(\mathrm{P})$, enquanto que nas frações solúveis $(S)$, houve detecção do anticorpo somente na maior concentração de digitonina $(5 \mathrm{mg} / \mathrm{mL})$, resultado que é compatível com os ensaios de atividade PRODH realizados em ambas as frações, em que foi observada maior atividade na fração insolúvel (P), quando comparada com a fração insolúvel (S) (dados não mostrados). Observa-se também que a proteína está presente em todas as frações insolúveis $(\mathrm{P})$, possivelmente pelo fato da mesma encontrar-se localizada na membrana mitocondrial, o que facilitaria a extração a partir de concentrações menores de digitonina. 


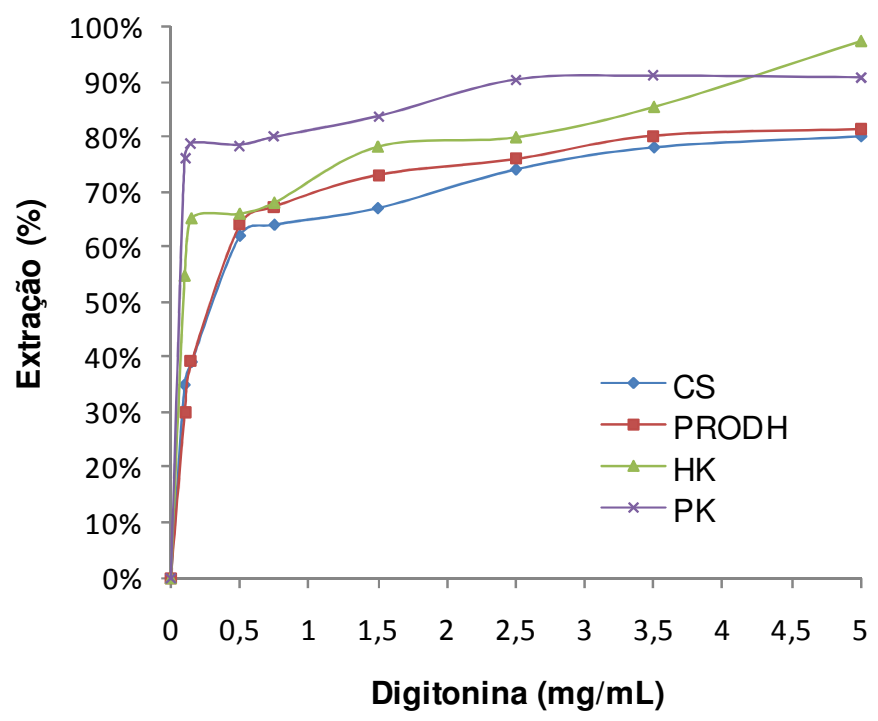

A

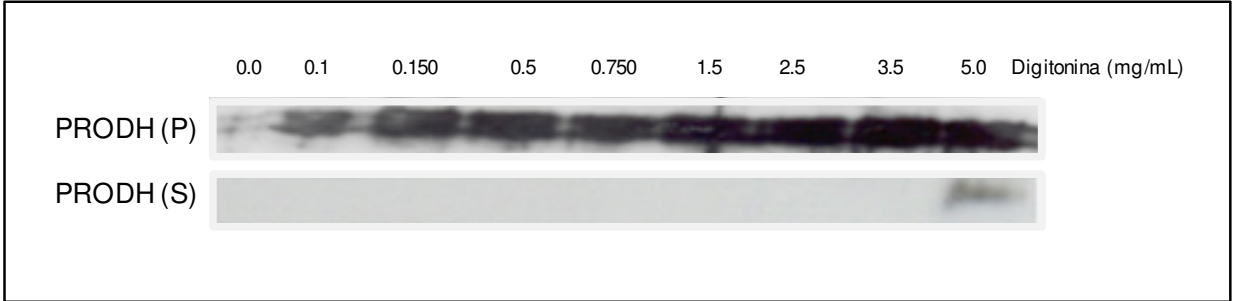

Figura 23. Localização subcelular da PRODH de T. cruzi por extração com digitonina. (A) Formas epimastigotas de $T$. cruzi foram tratadas com diferentes concentrações de digitonina e as atividades piruvato quinase (PK), hexoquinase (HK), citrato sintase e prolina desidrogenase (PRODH) foram medidas. (B) Frações solúveis $(\mathrm{S})$ e insolúveis $(\mathrm{P})$ extraídas com diferentes concentrações de digitonina foram submetidas à análise por Western blotting e marcadas com o anticorpo específico anti-PRODH. 


\subsection{Expressão e purificação da PRODH}

O gene de interesse codificando a proteína PRODH de T. cruzi foi subclonado no vetor de expressão pAE (RAMOS et al., 2004) e os ensaios iniciais de expressão foram realizados a $37^{\circ} \mathrm{C}$ com $1 \mathrm{mM}$ IPTG por 4 horas (Figura 24A). Nessas condições a expressão da proteína de interesse aumentou ao longo do tempo, porém em forma insolúvel, e, portanto, inativa. Com o objetivo de expressá-la na fração solúvel e ativa, novas tentativas foram realizadas diminuindo a concentração do indutor IPTG $(0,5 \mathrm{mM}) \mathrm{e}$ a temperatura de indução $\left(20^{\circ} \mathrm{C}\right)$, bem como aumentando o tempo de indução até aproximadamente 16 horas (Figura 24B). Nessas condições obteve-se uma fração maior de proteína solúvel, a qual foi purificada por afinidade em resina de $\mathrm{Ni}^{2+}$-NTASepharose. Através de ensaios de western blotting utilizando o anticorpo anti-PRODH, foi possível detectar a PRODH recombinante, a qual apresentou uma única banda de aproximadamente $66 \mathrm{kDa}$, tamanho compatível com o esperado para a proteína fusionada à cauda de histidina codificada pelo vetor (Figura 24C).

A

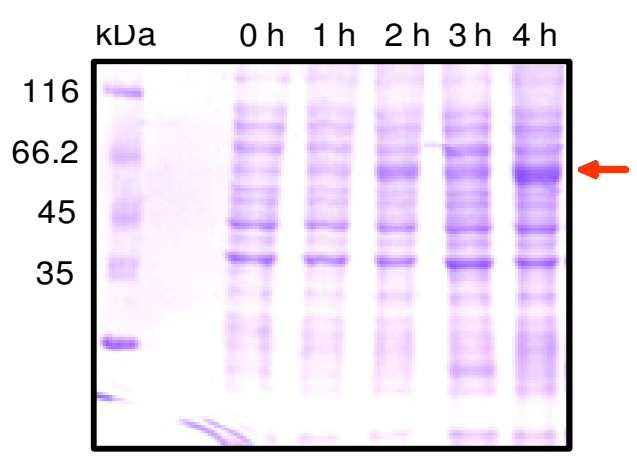

B

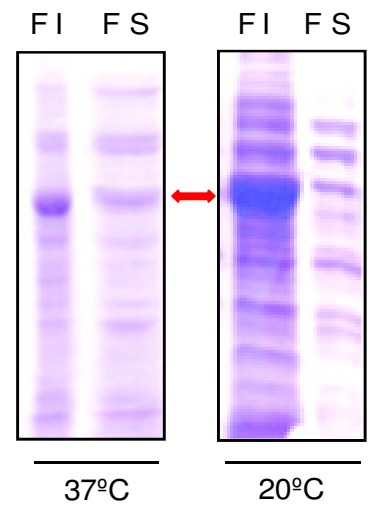

C

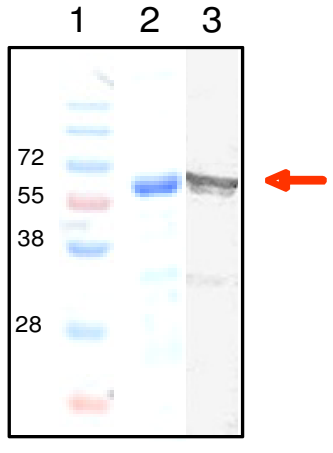

Figura 24. Análise da expressão da PRODH. (A) Eletroforese em gel SDS-PAGE 10\% mostrando a expressão da proteína PRODH no vetor pAE ao longo de 4 horas de indução com $1 \mathrm{mM}$ de IPTG. (B) Frações solúveis (FS) e insolúveis (FI) em extrato de E. coli expressando PRODH em diferentes temperaturas, $37^{\circ} \mathrm{C}$ e $20^{\circ} \mathrm{C}$. (C) Ensaio de western blotting com o anticorpo anti-PRODH contra a proteína recombinante. A canaleta 1 corresponde ao padrão de massa molecular em $\mathrm{kDa}$, a canaleta 2 à PRODH purificada com $500 \mathrm{mM}$ de imidazol da fração solúvel a $30^{\circ} \mathrm{C}$. Na canaleta 3, observa-se uma banda que corresponde à PRODH recombinante. As setas vermelhas indicam a proteína de interesse expressa com massa molecular de aproximadamente $66 \mathrm{kDa}$. 


\subsection{Caracterização da PRODH}

Os parâmetros cinéticos da PRODH recombinante foram avaliados através do ensaio prolina: DCICP oxirredutase, e os dados obtidos ajustados à função hiperbólica segundo o modelo de Michaelis-Menten $\left(\mathrm{R}^{2}=0,99\right)$. Obtiveram-se valores de $\mathrm{V}_{\max }$ de $0,066 \pm 0,002 \mu \mathrm{mol} / \mathrm{min} / \mathrm{mg} \mathrm{e}_{\mathrm{m}}$ de 16,58 $\pm 1,69 \mu \mathrm{M}$ (Figura 25).

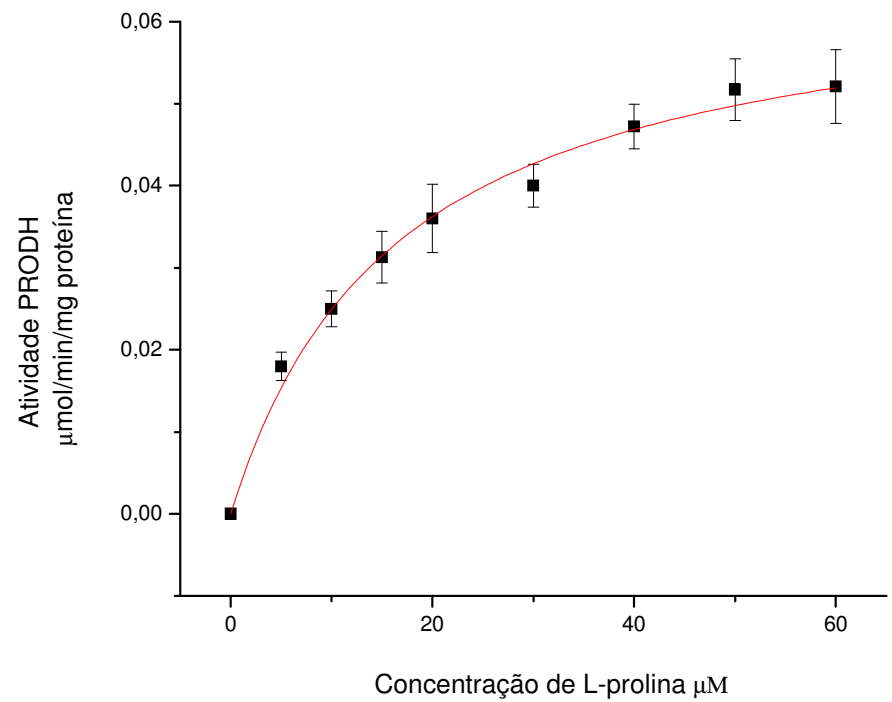

Figure 25. Efeito da concentração de substrato na atividade da PRODH recombinante. As taxas da atividade da enzima foram obtidas em função da concentração de prolina (0$60 \mu \mathrm{M})$. Os dados foram ajustados a clássica função hiperbólica de MichaelisMenten $\left(R^{2}=0.99\right)$. 
A capacidade da PRODH recombinante utilizar substratos alternativos como Dprolina e hidroxiprolina foi testada, mas esses compostos apresentaram baixa atividade quando comparada com a atividade na presença de L-prolina (Figura 26A). Também foram verificados os possíveis cofatores utilizados pela PRODH. Para isso, a reação enzimática da PRODH foi realizada na presença de FAD, $\mathrm{NAD}^{+}$e $\mathrm{NADP}^{+}$(Figura 26 B). A leitura de absorbância dessas reações foi acompanhada em espectrofotômetro (comprimento de onda de 200-600 nm). A literatura relata que espectros com bandas de absorbância entre 500-600 nm correspondem a FADH 2 (FAD reduzido), enquanto que espectros com bandas de absorbância entre 420- $480 \mathrm{~nm}$ correspondem a FAD oxidado (GHISLA, 1980; GHISLA; MASSEY, 1986). Nossos ensaios mostraram a aparição de um pico de absorbância em torno de $510 \mathrm{~nm}$ que corresponde a $\mathrm{FADH}_{2}$ em função da atividade da proteína (Figura 27). No entanto, na presença de $\mathrm{NAD}^{+}$não foi observado nenhum sinal correspondente ao esperado (Figura 27). 


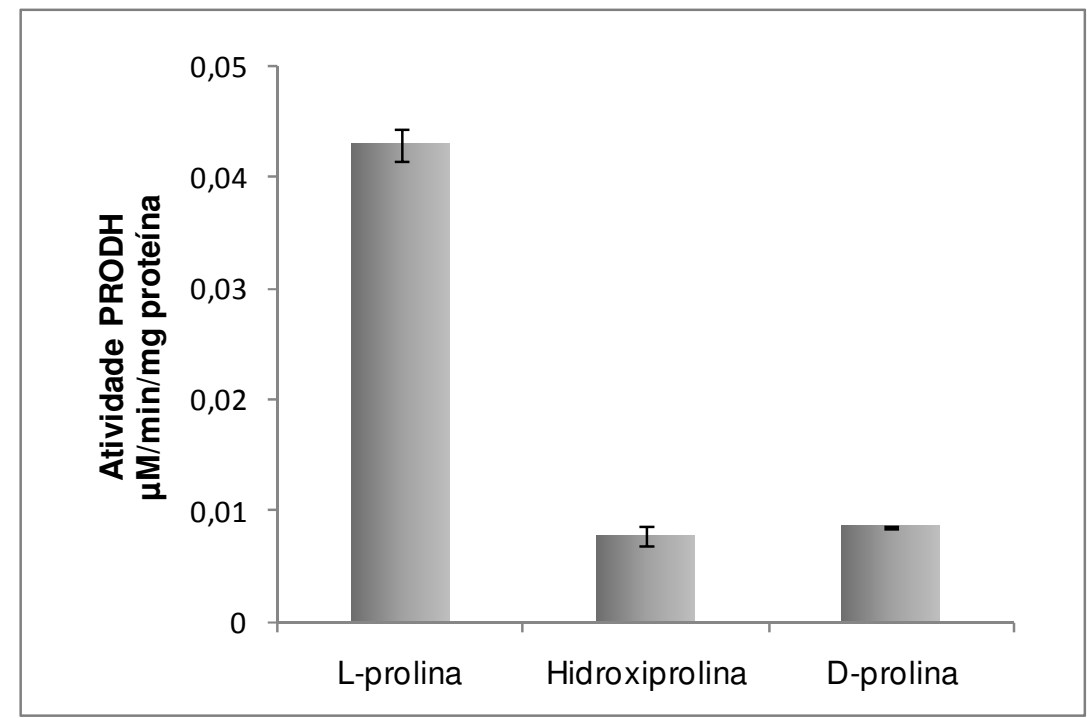

A

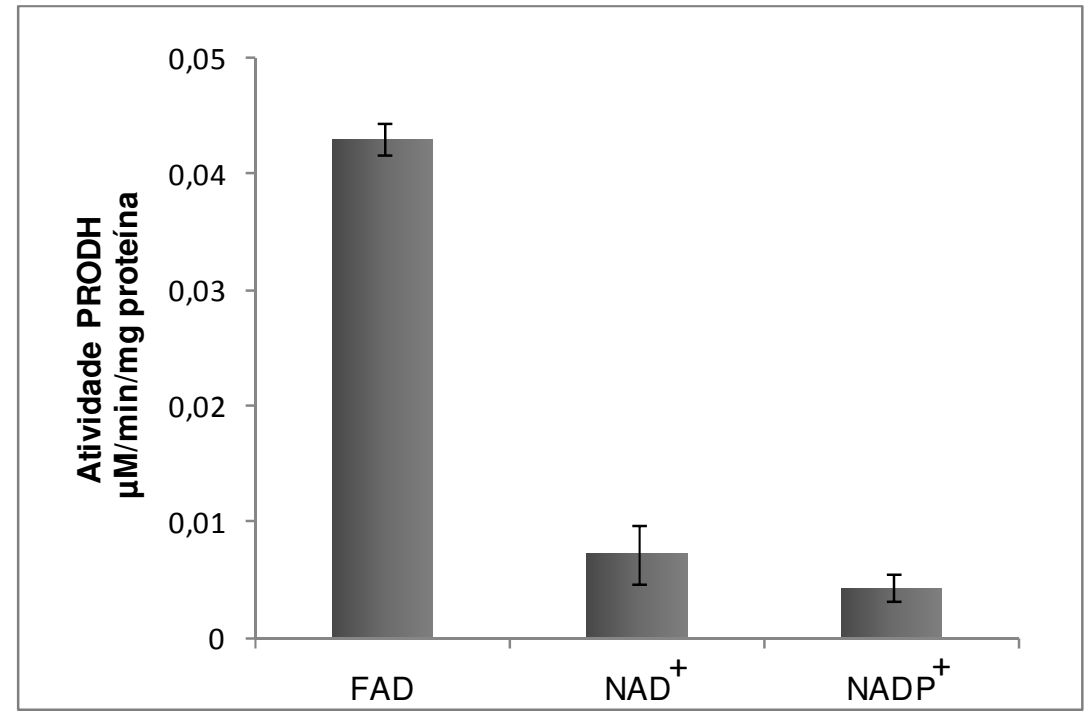

B

Figura 26. Atividade da PRODH recombinante em função de diferentes cofatores e substratos. (A) Na presença de diferentes substratos. (B) Na presença de diferentes cofatores. Os resultados correspondem a média e desvio padrão de três experimentos independentes. 


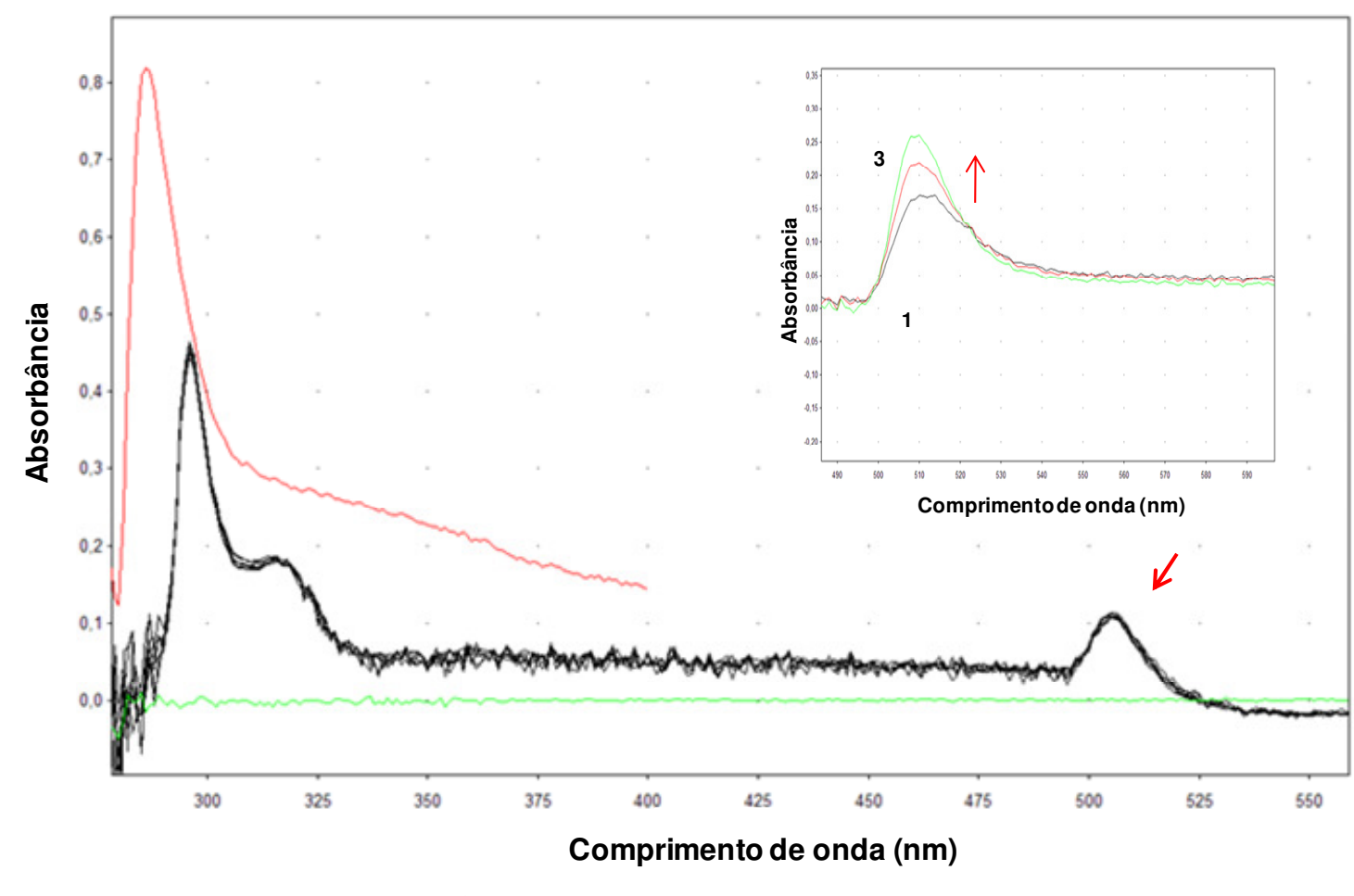

Mistura da reação-Controle $\longrightarrow$ PRODH recombinante NAD

- PRODH recombinante FADH

Figura 27. Avaliação do produto formado na reação de atividade da PRODH por espectrofotometria de varredura. Ensaio de atividade com a proteína recombinante PRODH utilizando $\mathrm{NAD}^{+}$e FAD como cofatores. O pico de absorbância na região de aproximadamente $500 \mathrm{~nm}$ corresponde ao produto formado na reação com adição de FAD (indicado pela seta vermelha). A curva em vermelho refere-se ao ensaio de atividade da PRODH na presença do cofator $\mathrm{NAD}^{+}$. Em destaque é mostrado o aumento do produto formado através da redução de FAD $\left(\mathrm{FADH}_{2}\right)$ ao longo do tempo (3 min), observa-se o pico esperado na região de $510 \mathrm{~nm}$. 


\subsection{A possível regulação da atividade da PRODH recombinante por $\mathrm{Ca}^{2+}$}

Como descrito anteriormente, a análise da seqüência de aminoácidos da proteína PRODH revelou a presença de um possível motivo de ligação ao $\mathrm{Ca}^{2+}$. Além disso, a proteína recombinante foi reconhecida pelo anticorpo policlonal anti-PRODH e pelo agente fluorescente de ligação ao cálcio, Quin 2, o qual também revelou uma banda do tamanho esperado para a proteína recombinante quando esta foi analisada por Western blotting (Figura 28). Nesse sentido, investigamos a possível regulação da atividade da PRODH por $\mathrm{Ca}^{2+}$, mediante ensaios de inibição com EDTA e EGTA. Em ambos os tratamentos observamos uma diminuição significativa da atividade PRODH, sendo de aproximadamente dez vezes na presença de EDTA e quase cinco vezes na presença de

EGTA. Estes dados indicam que essa enzima pode ser regulada por $\mathrm{Ca}^{2+}$ ou $\mathrm{Mg}^{2+}$ (Figura 29). 


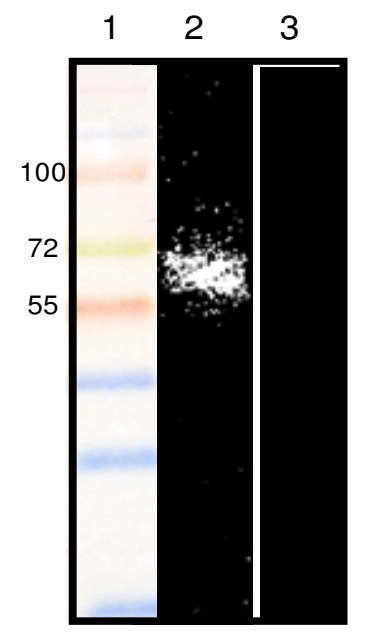

Figura 28. Detecção fluorescente, visualizada por luz $\mathrm{UV}$, do $\mathrm{Ca}^{2+}$ ligado à proteína PRODH utilizando o reagente QUIN-2. A proteína PRODH recombinante foi transferida para membrana de PVDF. Essa membrana foi incubada ou não com 10 $\mu \mathrm{M}$ de $\mathrm{CaCl}_{2}$ e revelada com QUIN-2. A canaleta 1 corresponde ao padrão de massa molecular Na canaleta 2, observa-se uma banda que corresponde à PRODH recombinante. A canaleta 3 corresponde ao controle negativo

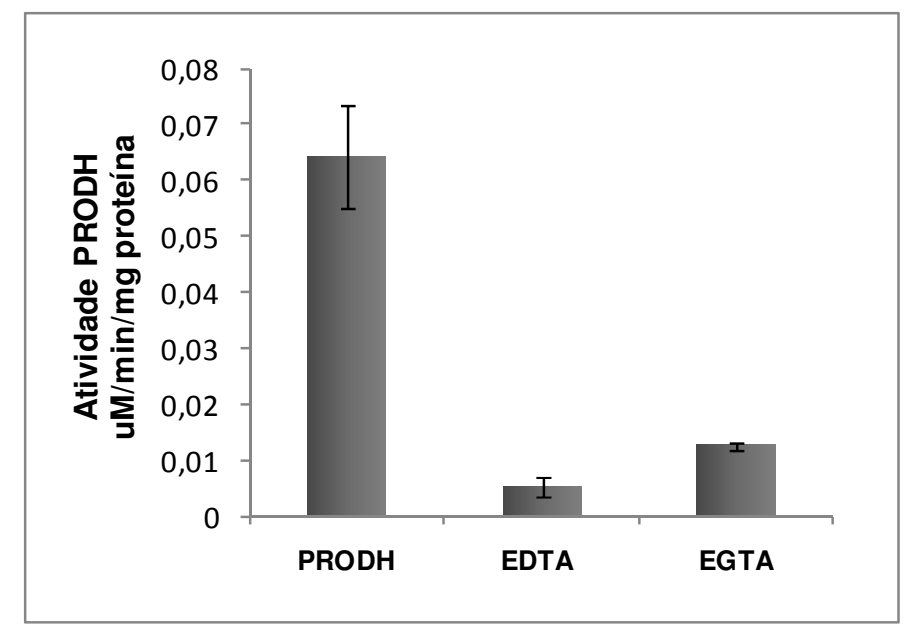

da PRODH recombinante na presença de quelantes de íons divalentes. Os ensaios de atividade da proteína recombinante foram realizados na presença EDTA e EGTA $(10 \mu \mathrm{M})$. Os resultados correspondem a média de três experimentos independentes. 


\subsection{Ensaios de estresse oxidativo}

\subsubsection{Ensaios com leveduras complementadas}

Muitos trabalhos descrevem o importante papel do metabolismo de prolina na defesa contra vários estresses bióticos e abióticos e com propriedades que beneficiam uma variedade de organismos. Assim, além de contribuir para as necessidades energéticas das células, o metabolismo de prolina tem se mostrado importante para a manutenção da homeostase redox intracelular em diferentes organismos, tais como fungos patogênicos (CHEN; DICKMAN, 2005), leveduras (NOMURA; TAKAGI, 2004; CHEN et al., 2006), bactérias (KRISHNAN; BECKER, 2006; MONAGHA; LEYS; SCRUTTON, 2007), plantas (SKOPELITIS et al., 2006) e células de mamíferos (HU et al., 2007; KRISHNAN et al., 2008). Diante disso, foi proposto testar as leveduras, contendo o gene codificante da PRODH de T. cruzi, obtidas neste estudo em relação à sua resistência ao estresse oxidativo, a fim de estabelecer um possível papel funcional para essa enzima.

Inicialmente foram padronizadas as condições de avaliação do estresse oxidativo em leveduras. A levedura mutante para o gene PRODH $(\triangle P U T 1)$, o controle positivo $(\triangle P U T 1 / \mathrm{pYES})$ e a levedura complementada ( $\triangle P U T 1 / \mathrm{PRODH})$ foram incubadas em meio seletivo ( $\mathrm{SD}^{\text {-URA }}$ ) suplementado com várias concentrações de $\mathrm{H}_{2} \mathrm{O}_{2}(100 \mu \mathrm{M}, 500$ $\mu \mathrm{M}$ e $1 \mathrm{mM})$ na presença de prolina $(5 \mathrm{mM}$ e $10 \mathrm{mM})$.Isto foi feito de acordo com protocolos já estabelecidos por Chen et al. (2006) e Takagi et al. (2000) para estresse oxidativo em cepas de leveduras nocautes para o gene PUT1. A duração do desafio foi baseada no tempo necessário para expressão da proteína PRODH sob o indutor GAL que é de aproximadamente 6 horas. Não houve nenhum efeito observável nas leveduras utilizando concentrações de $100 \mu \mathrm{M}, 500 \mu \mathrm{M}$ de $\mathrm{H}_{2} \mathrm{O}_{2}$ e $5 \mathrm{mM}$ de prolina. Somente foram observadas diferenças quando as concentrações utilizadas foram maiores ou iguais a $500 \mu \mathrm{M}$, sendo que o efeito mais significativo foi observado a uma concentração de 1

$\mathrm{mM}$ de $\mathrm{H}_{2} \mathrm{O}_{2}$ e com $10 \mathrm{mM}$ de prolina, concentrações escolhidas para os ensaios que se seguiram.

Quando foi comparado o efeito do $\mathrm{H}_{2} \mathrm{O}_{2}$ na levedura nocaute para o gene PRODH endógeno ( $\triangle \mathrm{PUT} 1)$ e controle $(\triangle \mathrm{PUT} / \mathrm{pYES})$ com a levedura transformada com o gene PRODH de $T$. cruzi ( $\triangle \mathrm{PUT} / \mathrm{PRODH})$, pode-se observar que, sob estresse oxidativo (1 $\mathrm{mM}$ de $\mathrm{H}_{2} \mathrm{O}_{2}$ ), na presença de prolina $(10 \mathrm{mM})$, as leveduras nocaute e controle possuem maior viabilidade celular no tempo final de 6 horas (aproximadamente 
90\%) em relação à levedura complementada (viabilidade de $37 \%$ pós-tratamento)

(Figura 30A). Como os dados foram contrários ao esperado, resolveu-se confirmar este padrão de sensibilidade ao estresse oxidativo utilizando T-butil hidroperóxido no desafio. Nesse caso, observou-se a mesma tendência, com valores de viabilidade de $85 \%$ para as leveduras nocaute e controle e de 53\% para a levedura complementada (Figura 30B).

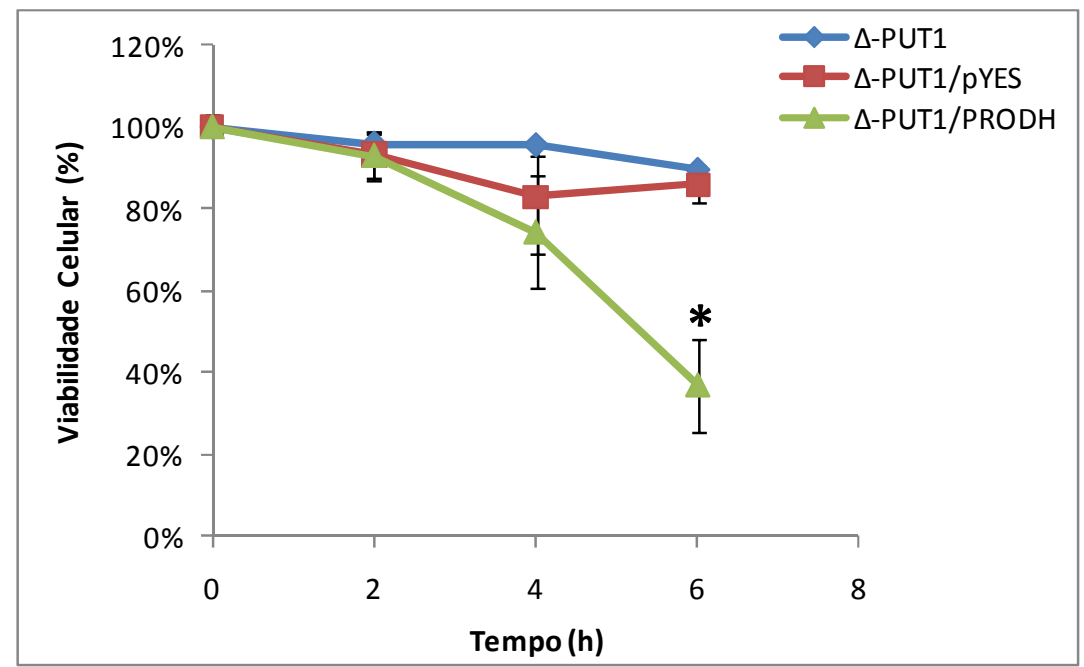

A

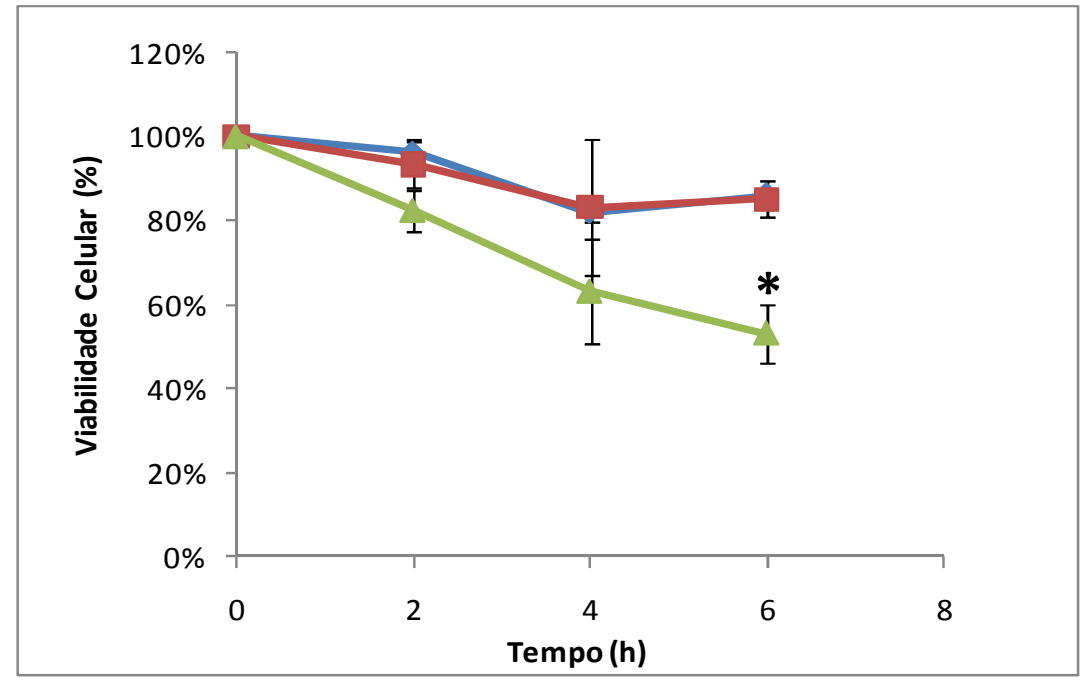

B

Figura 30. Viabilidade celular das leveduras em estudo, submetidas a estresse oxidativo. As leveduras nocaute para o gene PRODH $(\triangle-P U T 1)$, controle $(\triangle-P U T 1 / \mathrm{pYES})$ e complementada $(\Delta-P U T 1 / \mathrm{PRODH})$ foram submetidas a estresse oxidativo durante 6 horas. $\mathrm{O}$ estresse foi realizado na presença de peróxido de hidrogênio inorgânico (A) e orgânico ( $T$-butyl hydroperoxide) $(1 \mathrm{mM})(\mathbf{B})$. Os valores representam a média de três experimentos independentes. $\left(^{*}\right)$ significância estatística $(\mathrm{p}<0.05)$. 
Ao serem confirmados os resultados anteriores, foi levantada a hipótese de que o mecanismo de resistência a estresse oxidativo poderia estar relacionado diretamente com a quantidade de prolina intracelular livre. Para avaliar esta possibilidade, foram realizadas medições da concentração de prolina interna livre em amostras de leveduras submetidas ao estresse oxidativo. Sendo assim, observou-se que a maior resistência ao estresse pode estar correlacionada com a maior quantidade intracelular de prolina livre, pois as leveduras que apresentaram maiores porcentagens de viabilidade celular sob estresse oxidativo foram aquelas que apresentaram maior quantidade de prolina intracelular livre, como mostrado na Figura 31.

Além disso, o experimento de quantificação de prolina livre demonstra mais uma vez a funcionalidade da complementação heteróloga, pois a levedura complementada possui os menores valores de prolina interna livre, já que a mesma é degradada pela PRODH heteróloga. As leveduras nocaute e controle para esse gene têm três vezes mais prolina interna livre devido ao fato de que a via de degradação de prolina não está ativa. Finalmente, foi verificada a proporção do estresse oxidativo sofrido pelas células de leveduras em estudo, através dos índices da razão GSSG/GSH. Foi observado que a levedura complementada apresentou os maiores valores para esse parâmetro quando comparada com as leveduras nocaute e controle (Figura 31), mostrando que o balanço redox celular está prejudicado, e que a prolina interna livre pode preservar o conteúdo de GSH necessário para a proteção celular. 


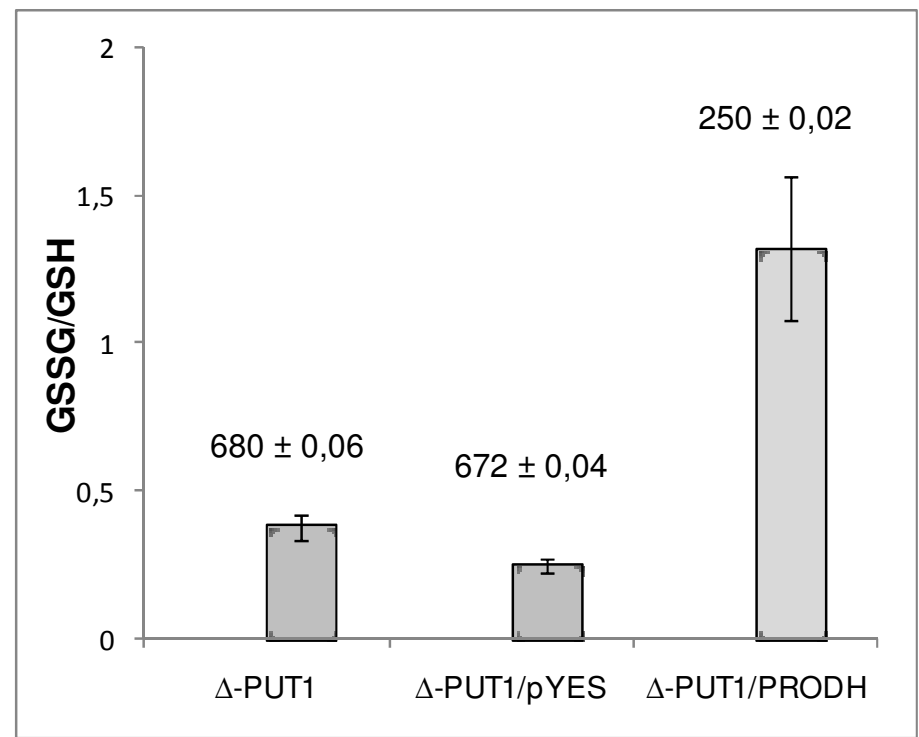

Figura 31. Valores da razão das taxas de GSSG/GSH e a concentração de prolina intracelular livre das leveduras em estudo submetidas a estresse oxidativo. As leveduras nocaute $(\triangle-P U T 1)$, controle $(\Delta-P U T 1 / \mathrm{pYES})$ e complementada $(\Delta$ $P U T 1 / \mathrm{PRODH})$ foram submetidas a estresse oxidativo por 6 horas. As atividades de glutationa oxidada (GSSG) e reduzida (GSH) foram medidas nos extratos protéicos das amostras de leveduras descritas acima. Os números em destaque acima indicam concentrações intracelulares de prolina livre $(\mu \mathrm{M})$ das células de leveduras em estudo $\left(1 \times 10^{6}\right)$. Para a obtenção dos valores dessas concentrações interna de prolina, uma curva padrão com várias concentrações de L-prolina foi utilizada. Os valores dos ensaios representam a média de três experimentos independentes. 


\subsubsection{Ensaios com epismastigotas de $T$. cruzi}

A partir dos resultados obtidos nos ensaios anteriores com as leveduras em estudo, observou-se que a maior concentração de prolina interna foi capaz de proteger as células sob estresse oxidativo, aumentando a resistência celular. Essa correlação entre concentração interna de prolina livre e resistência a estresse oxidativo também foi verificada em T. cruzi. Para isso, formas epimastigotas de T. cruzi foram submetidas a um desafio metabólico e posteriormente ao estresse oxidativo, já que em meio de cultura completo seria impossível discernir o efeito da prolina separadamente de outros aminoácidos ou fontes de carbono que poderiam agir como protetores desse estresse. Assim, todas as condições apropriadas com relação às concentrações de $\mathrm{H}_{2} \mathrm{O}_{2}$, prolina, glutamato, glicose e tempo foram pré-estabelecidas como descritas no item 3.10.2 em materiais e métodos.

$\mathrm{Na}$ realização deste ensaio, as células foram previamente incubadas por $48 \mathrm{~h}$ em PBS, suplementadas com $3 \mathrm{mM}$ de glicose e $3 \mathrm{mM}$ de glutamato (GLU), utilizados como controles no ensaio, e com 3 mM de L-prolina (PRO) em concentrações de saturação dos respectivos transportadores para cada substrato testado, o que garantiu que esses metabólitos não fossem fatores limitantes para as células. Posteriormente todos os grupos foram submetidos a estresse oxidativo $\left(\mathrm{H}_{2} \mathrm{O}_{2} 160 \mu \mathrm{M}\right)$ durante 12 horas e a viabilidade de cada caso analisada por ensaio de atividade da cadeia respiratória (método do MTT). Foi observada uma maior viabilidade de epimastigotas crescidos em prolina, seguido de glicose e glutamato (Figura 32A), sendo esse perfil de viabilidade similar ao obtido através da contagem dos parasitos aparentemente viáveis em câmara de Neubauer (dados não mostrados). A viabilidade das células parece estar acompanhada pela concentração de prolina interna livre como mostrado na Figura 32B, da mesma forma que a atividade da PRODH (dados não mostrados). 


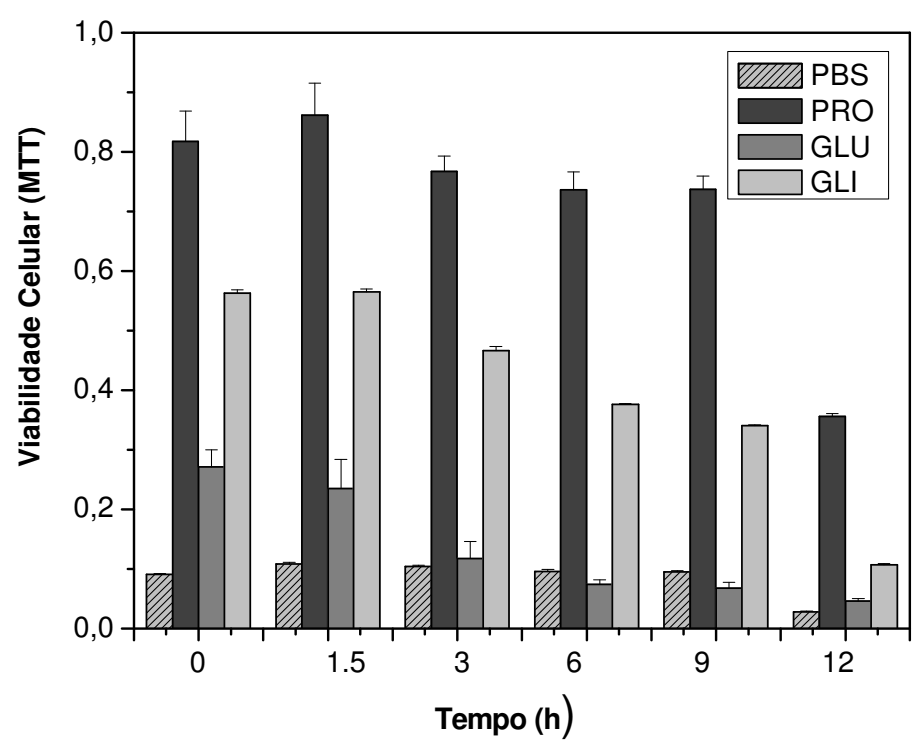

A

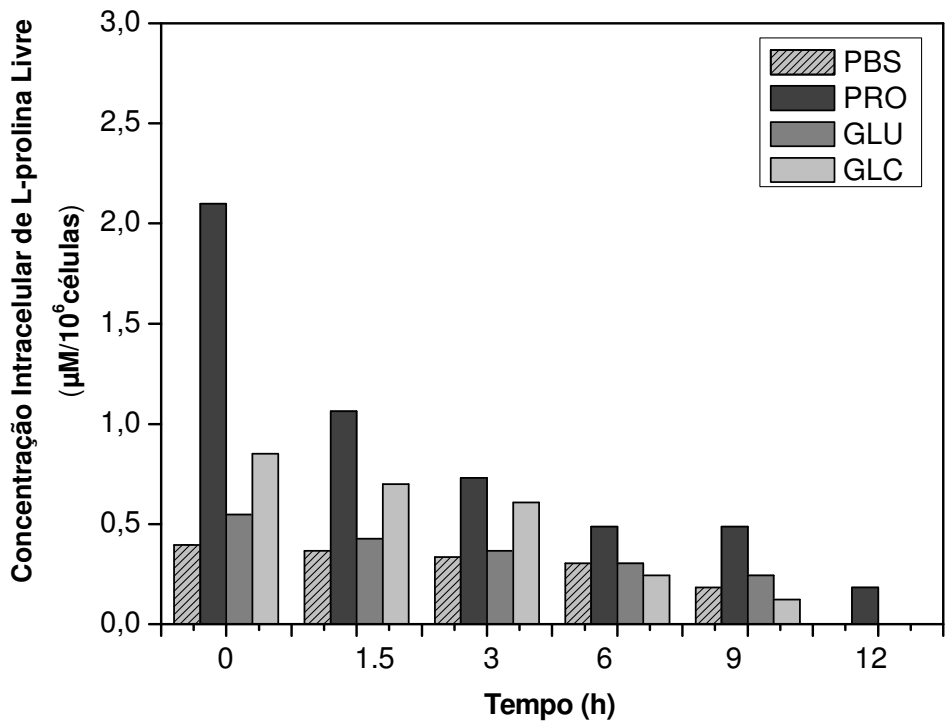

B

Figura 32. Viabilidade celular e concentrações intracelulares de prolina interna livre de formas epimastigotas de $T$. cruzi submetidas a estresse oxidativo. (A) As células (3 $\left.\times 10^{6} / \mathrm{mL}\right)$ foram pré-incubadas por 48 horas com PBS, PBS+prolina (PRO), PBS+glutamato (GLU), PBS+glicose (GLC) e posteriormente submetidas ao estresse oxidativo por 12 horas. (B) Alíquotas das células submetidas ao estresse oxidativo foram retiradas ao longo do tempo, e a concentração intracelular de prolina livre foi medida $(\mu \mathrm{M})$. Os valores representam a média de três experimentos independentes $(\mathrm{p}<0.05)$. 
$\mathrm{Na}$ busca por análogos de L-prolina que poderiam ter efeito tripanocida ou tripanostático, alguns compostos foram testados mediante realização de curvas de crescimento de epimastigotas de T. cruzi (trabalho de pós-doutoramento da Dra Anahí Magdaleno). Foi observado que dentre os análogos de prolina testados, o ácido carboxílico azeditina e o 3,4-Dehidro-DL-prolina apresentaram altas concentrações

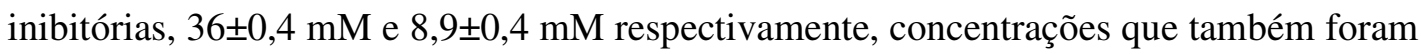
tóxicas para as células de mamíferos. Já o ácido L-pipecolínico não apresentou nenhum efeito nas concentrações avaliadas. Os ensaios com o ácido carboxílico 4-tiazolidina (T4C) mostraram uma inibição dose-dependente no crescimento de epimastigotas, com diferenças significativas entre o crescimento das células tratadas e não tratadas $(p<0,01)$, e $\mathrm{CI}_{50}$ de 0,89 $\pm 0,02 \mathrm{mM}$. Além de ter mostrado um efeito na viabilidade das formas epimastigotas de T. cruzi, as concentrações de T4C testadas em epimastigotas (entre 0,1 e $1 \mathrm{mM})$ não foram tóxicas às células de mamífero $\left(\mathrm{CI}_{50}=11,4 \pm 0,36 \mathrm{mM}\right)$ (dados do laboratório).

Diante disso, decidiu-se investigar qual seria o mecanismo de ação do T4C, e se o seu efeito poderia estar relacionado à inibição de alguma enzima da via da prolina, como a PRODH. Esta parte do trabalho foi realizada em colaboração com os pós-doutorandos Anahí Magdaleno e II-Young Ahn. Está hipótese foi confirmada através de ensaios de atividade da enzima prolina desidrogenase (PRODH) utilizando L-prolina e D-prolina como substratos, na presença e ausência de T4C, onde observou-se que não houve nenhuma alteração na atividade da PRODH (Figura 33). Já em ensaios de competição de transporte, ambos os transportadores de prolina foram parcialmente inibidos (\% $\mathrm{I}=$ $68 \pm 3,02$ no sistema A, baixa capacidade de transporte, e \% $\mathrm{I}=91 \pm 12,49$ sistema $\mathrm{B}$, alta capacidade de transporte) (Figura 34). Esse resultado sugere que o T4C pode agir como um inibidor competitivo dos transportadores deste aminoácido e não como inibidor de enzimas da via da prolina. 


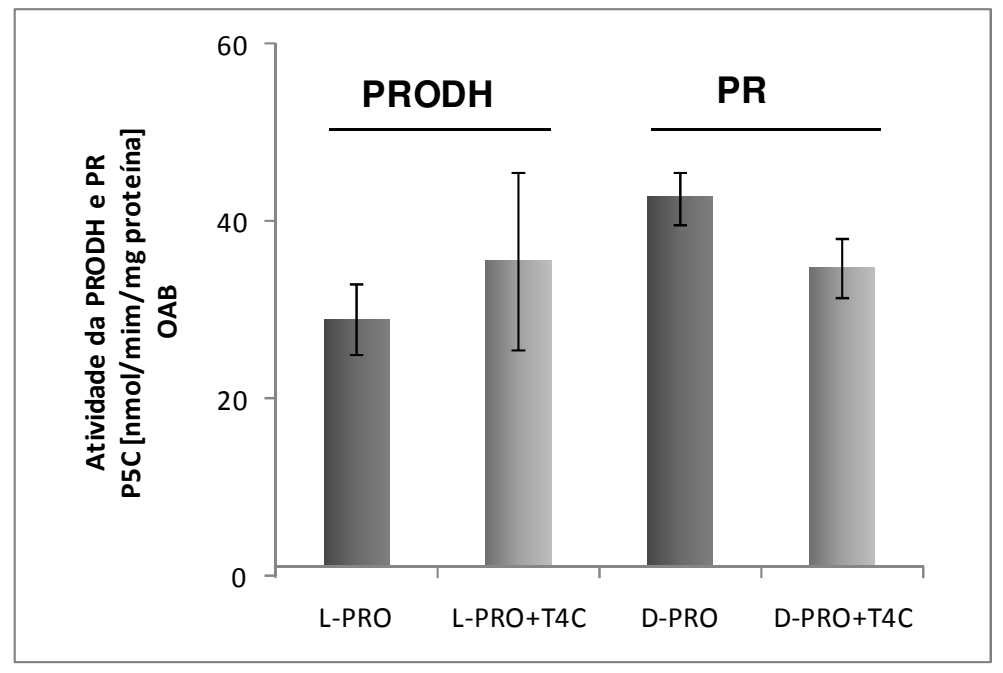

Figura 33. Atividade da enzima PRODH e PR em extrato total de epimastigotas de T. cruzi. As reações de atividade PRODH foram realizadas utilizando D-prolina ou L-prolina como substratos, na presença ou ausência de $0,5 \mathrm{mM}$ de T4C.

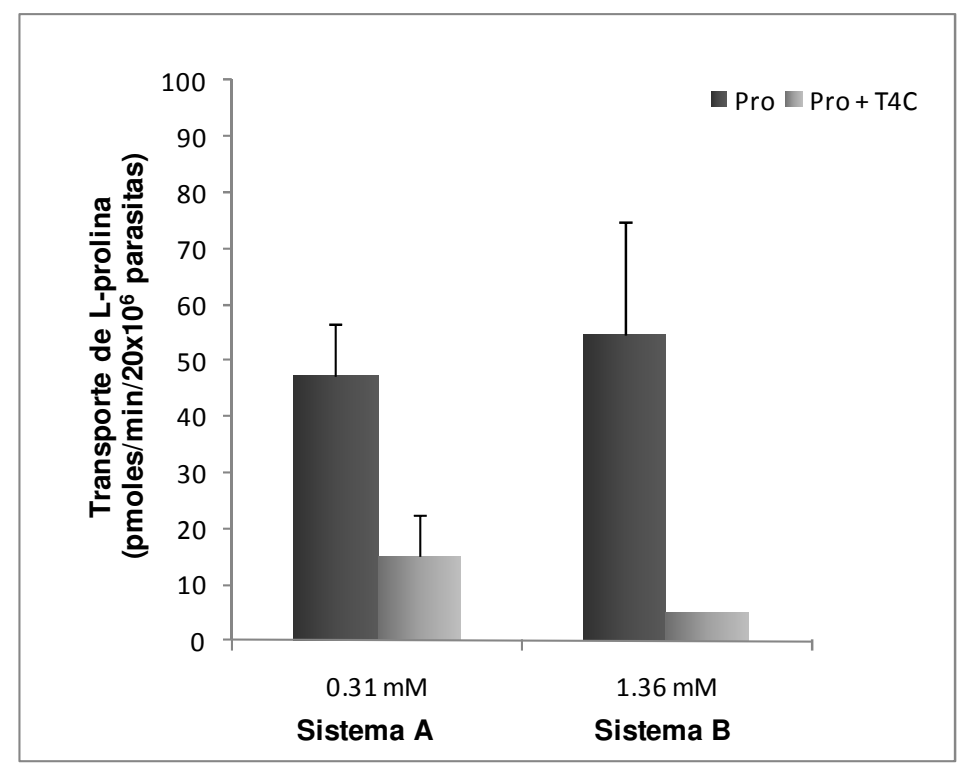

Figura 34. Transporte de L-prolina na presença de $T 4 C(0,5 \mathrm{mM})$ em epimastigotas de $T$. cruzi. O transporte de prolina foi medido nas concentrações de prolina correspondentes aos valores de $\mathrm{Km}$ do sistema A $(0,31 \mathrm{mM})$ e sistema B $(1,36 \mathrm{mM})$. 
O fato do T4C interferir no transporte de prolina, possivelmente, faz com que haja modificações no conteúdo de prolina intracelular e conseqüentemente diminua a resistência a estresse oxidativo das células. Assim, para melhor entender o envolvimento do metabolismo da prolina na resistência ao estresse oxidativo bem como a interação do T4C nesse processo, três variáveis foram consideradas para a realização deste ensaio. A primeira foi o fato das células serem submetidas a um desafio metabólico (como já descrito anteriormente), para isso, as células foram pré-incubadas por 48 horas com Lprolina (PRO) e glicose (controle). A segunda variável é que essas células também foram submetidas a tratamento na ausência e presença de $0,5 \mathrm{mM}$ de $\mathrm{T} 4 \mathrm{C}$, e a terceira foi o desafio com $\mathrm{H}_{2} \mathrm{O}_{2}$ (ou não) por 3 horas. A viabilidade de cada caso foi analisada por ensaio de MTT.

Como esperado, observamos que depois das 48 horas do desafio metabólico (antes do desafio oxidativo), os parasitos incubados com as fontes de carbono prolina e glicose já apresentavam diferenças significativas na viabilidade quando comparada com as células incubadas somente com PBS $(p<0,01)$ (Figura 30A). Além disso, observamos que as culturas pré-incubadas com PRO, GLI e tratadas com T4C já apresentavam diferenças significativas $(p<0,01)$ quando comparadas com o grupo de células não tratadas com T4C (MAGDALENO et al., 2009).

As concentrações de prolina interna livre de epimastigotas de $T$. cruzi, submetidos ao desafio metabólico por $48 \mathrm{~h}$ de incubação, mostrou que no grupo de parasitos incubados com prolina havia duas vezes mais prolina interna livre $(4,52 \mu \mathrm{M} / 10$ ${ }^{6}$ células) do que no grupo incubado com glicose $\left(2,26 \mu \mathrm{M} / 10^{6}\right.$ células), indicando que quando estes parasitos são avaliados posteriormente sob estresse oxidativo, este metabólito pode ser transportado e acumulado. Na presença de T4C, tais concentrações foram mantidas $\left(\mathrm{PBS}=0,88 \mu \mathrm{M} / 10^{6}\right.$ células) ou reduzidas $\left(\mathrm{PRO}=2,87 \mu \mathrm{M} / 10^{6}\right.$ células e GLI 1,29 $\mu \mathrm{M} / 10^{6}$ células).

A Figura 35A mostra que, embora o T4C seja um análogo de L-prolina, o mesmo não apresenta efeito protetor nas células sob estresse oxidativo, ao contrário, o tratamento com T4C mostrou ter efeito sinérgico com cada nutriente, e a viabilidade celular diminuída em 75\% em PBS+T4C, 88\% em PRO+T4C e 62\% GLI+T4C. Essa redução da viabilidade celular foi ainda mais significativa $(p<0,01)$ quando os grupos foram tratados com T4C e desafiados com $\mathrm{H}_{2} \mathrm{O}_{2}$, destacando o grupo T4C+PRO sob estresse oxidativo $(p<0,05)$. Na Figura 35B, pode-se observar diferenças significativas 
nas concentrações de prolina interna livre entre as células submetidas a estresse oxidativo por 3 horas na presença de T4C $(p<0,01)$.

Embora tenha sido observado que as células incubadas somente com PRO apresentaram maior resistência ao estresse oxidativo, não foi verificado neste ensaio, diferença significativa da viabilidade e das concentrações de prolina interna livre entre os grupos tratados com prolina e glicose sob estresse oxidativo ou não $(p<0,05)$, o contrário do observado no experimento anterior (Figura 35A e B). 


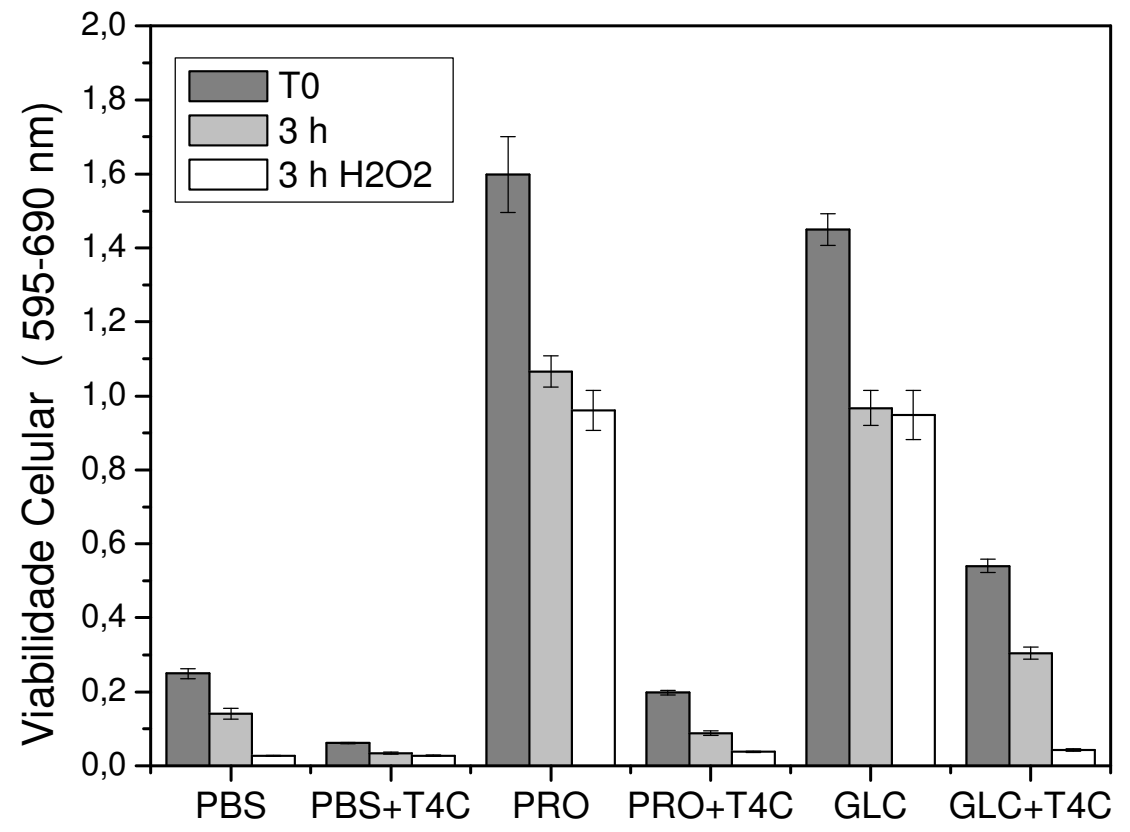

A

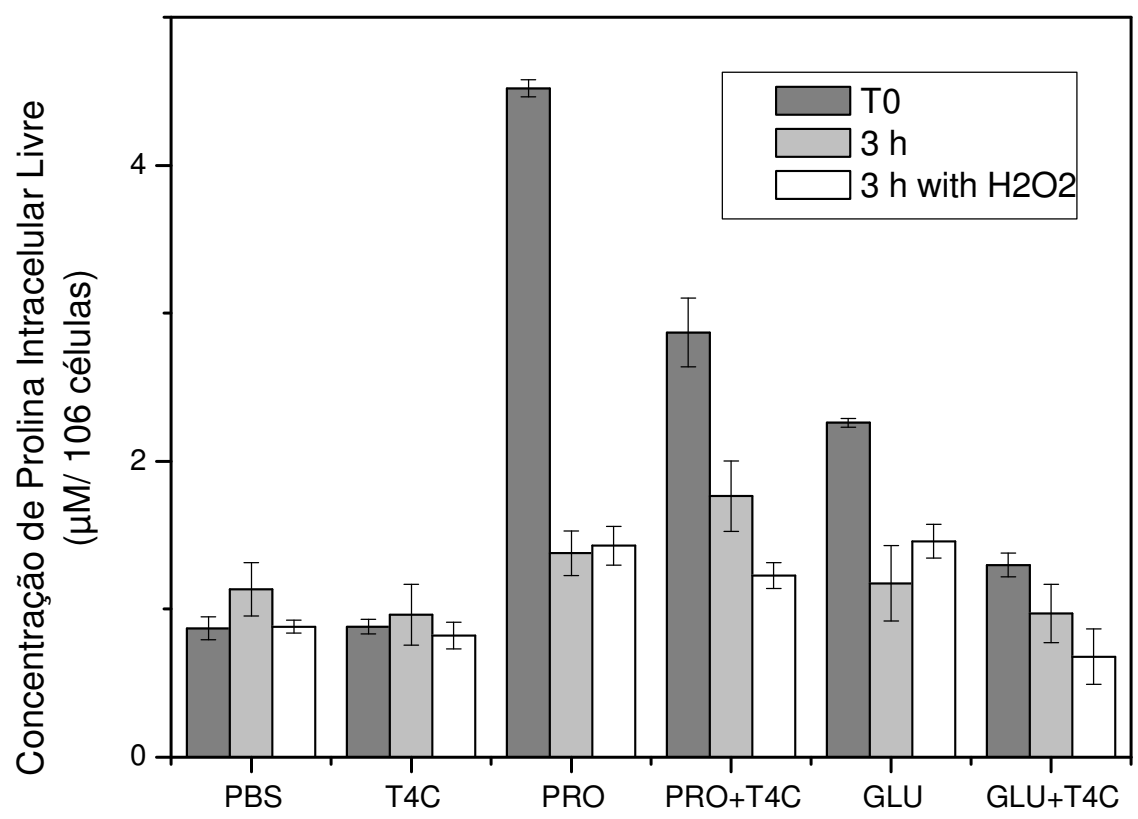

$B$

Figura 35. Viabilidade celular e concentrações intracelulares de prolina interna livre de epimastigotas de $T$. cruzi submetidos a estresse oxidativo. (A) As células ( $3 \mathrm{x}$ $10^{6} / \mathrm{mL}$ ) foram previamente incubadas em PBS, L-prolina em PBS (PRO), glicose em PBS tratadas ou não com $0,5 \mathrm{mM}$ de T4C (PBS + T4C, PRO+ T4C e GLI+T4C). Após lavagens, os parasitos foram incubados por $3 \mathrm{~h}$ em PBS na presença e ausência de $\mathrm{H}_{2} \mathrm{O}_{2}(160 \mu \mathrm{M})$. (B) A concentração intracelular de prolina livre $(\mu \mathrm{M})$ foi medida em função do nutriente, estresse oxidativo e tratamento com T4C, como descrito acima. Os valores representam a média de três experimentos independentes. 
Com o objetivo de estudar a interação entre T4C e estresse oxidativo, formas epimastigotas de $T$. cruzi foram submetidas a $80 \mu \mathrm{M}$ de $\mathrm{H}_{2} \mathrm{O}_{2}$ por 90 minutos em PBS na presença e ausência de $0,25 \mathrm{mM}$ de $\mathrm{T} 4 \mathrm{C}$, e as diferenças entre cada tratamento $\left(\mathrm{H}_{2} \mathrm{O}_{2}\right.$ ou T4C) e os seus respectivos controles foram significativas $(p<0,01)$. O número de células tratadas com T4C reduziu 55\% em relação ao controle, e as células incubadas simultaneamente em $\mathrm{T} 4 \mathrm{C}$ e $\mathrm{H}_{2} \mathrm{O}_{2}$ mostraram uma redução significativa de $75 \%$ no crescimento do parasito, sugerindo um efeito sinérgico entre $\mathrm{T} 4 \mathrm{C}$ e $\mathrm{H}_{2} \mathrm{O}_{2}$ (Figura 36). Este resultado confirma o efeito sinérgico do tratamento combinado entre T4C e estresse oxidativo.

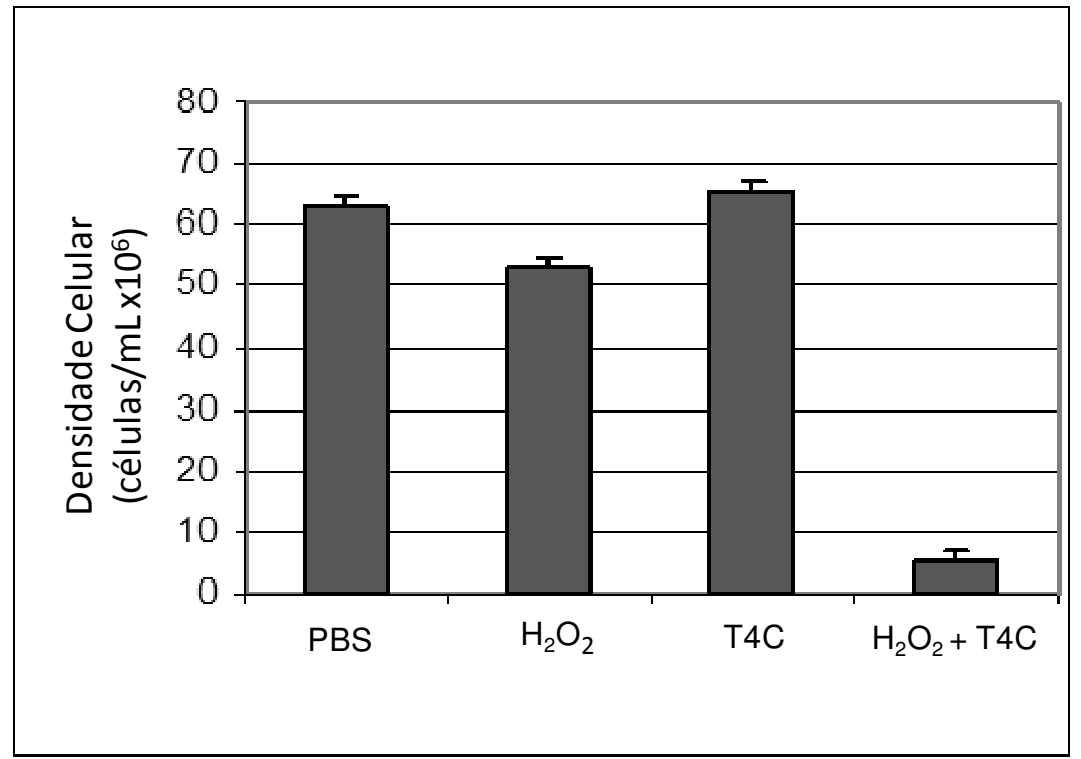

Figura 36. Densidade celular de epimastigotas de $T$. cruzi submetidos a estresse oxidativo. Os parasitos foram submetidos ao estresse oxidativo na presença de $80 \mu \mathrm{M} \mathrm{de} \mathrm{H}_{2} \mathrm{O}_{2}$, com ou sem adição da droga $(\mathrm{T} 4 \mathrm{C} 0,25 \mathrm{mM})$. O efeito dos tratamentos e os seus respectivos controles $\left(\mathrm{H}_{2} \mathrm{O}_{2}\right.$ ou T4C) foram medidos através do crescimento dos parasitos em LIT por 5 dias. Os valores representam a média de três experimentos independentes $(\mathrm{p}<0,01)$. 


\subsection{Participação da prolina na cadeia respiratória}

Segundo a literatura, as PRODHs catalisam a transferência de elétrons da prolina, produzindo P5C. O par de elétrons pode ser usado para a redução direta de oxigênio formando superóxido ou transferido para a cadeia transportadora de elétrons para contribuir com o gradiente de $\mathrm{H}^{+}$através da membrana interna mitocondrial, força motriz da fosforilação oxidativa (WHITE et al., 2007; TANNER, 2008). Uma vez verificada a localização da PRODH na mitocôndria e a sua capacidade de oxidar FAD (como acontece com a succinato desidrogenase), levantou-se a questão de que esta enzima em $T$. cruzi também poderia doar elétrons para a cadeia respiratória via redução de FAD, tal como acontece com a succinato desidrogenase.

Para responder esta pergunta foi realizado um fracionamento mitocondrial de T. cruzi em colaboração com a Prof ${ }^{a}$. Fernanda Gadelha (UNICAMP) (Fernandes, Inada et al., 2010). Essa metodologia consiste na fragmentação da mitocôndria formando pequenas vesículas, que quando analisadas demonstram alta atividade respiratória, quando incubadas com succinato, e baixa atividade para marcadores de matriz mitocondrial (citrato sintase, CS) (Figura 37). A atividade CS é significativamente menor em frações mitocondriais purificadas quando comparado com extrato total de epimastigota de $T$. cruzi. Isto mostra que as frações mitocondriais obtidas possuem as atividades de membrana ligadas ao funcionamento da cadeia respiratória, mas possuem pouca atividade das enzimas de matriz. Além disso, o fato das frações mitocondriais mostrarem maior atividade PRODH (Figura 38) indica a presença da PRODH associada à na membrana mitocondrial, como já demonstrada em outros eucariotos e sustenta a hipótese da sua participação na cadeia respiratória (WANG; BRANDRISS, 1987). 


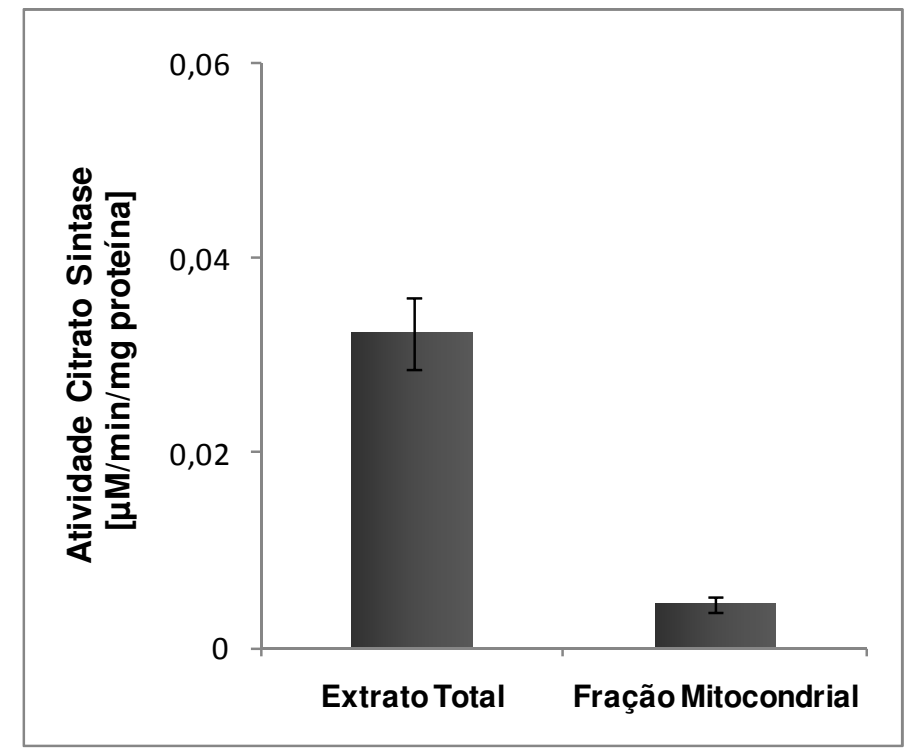

Figura 37. Atividade da enzima Citrato Sintase. A enzima CS foi utilizada como marcador de matriz mitocondrial. Sua atividade foi medida tanto na fração mitocondrial purificada quanto em extrato total de epimastigotas de $T$. cruzi.

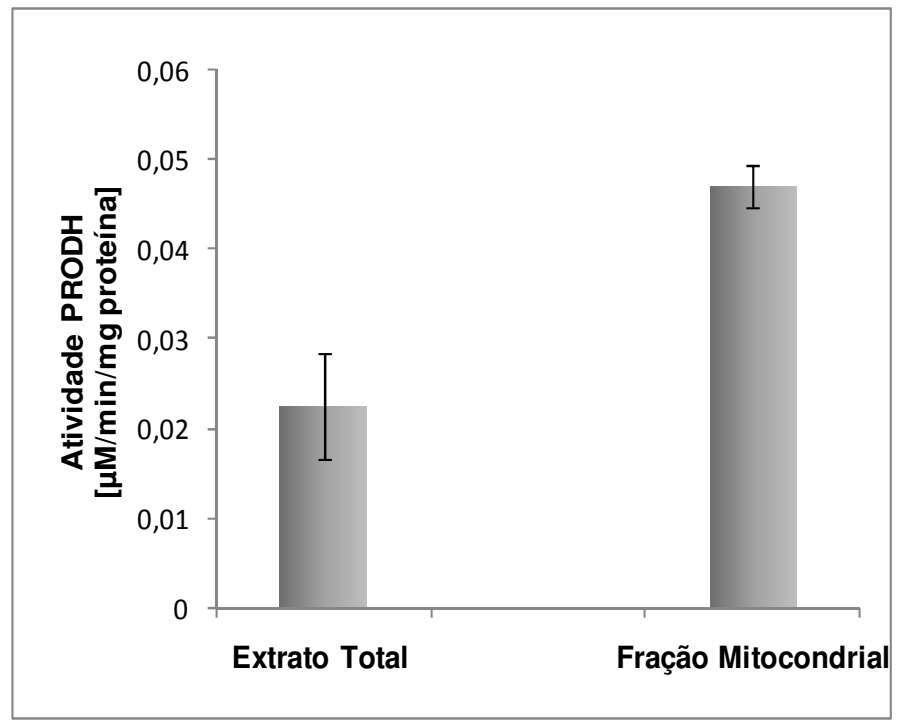

Figura 38. Atividade da PRODH em fração mitocondrial purificada de epimastigotas de $T$. cruzi. A atividade da enzima PRODH foi medida tanto na fração mitocondrial purificada quanto em extrato total de epimastigotas de T. cruzi. 
Ao comparar a capacidade oxidativa de FAD em membranas mitocondriais utilizando prolina $(5 \mathrm{mM})$ ou succinato $(5 \mathrm{mM})$ como substratos oxidáveis (Figura 39), observou-se que não houve diferenças significativas entre os dois tratamentos. $\mathrm{O}$ metabolismo da prolina na mitocôndria pode contribuir para o metabolismo energético através da geração de $\mathrm{FADH}_{2}, \mathrm{NADH}^{+}$e $\mathrm{H}^{+}$, pela ação da $\mathrm{PRODH}$, enzima $\mathrm{FADH}_{2}$, e em seguida pela ação da $\mathrm{P} 5 \mathrm{CDH}$, com formação de um $\mathrm{NADH}^{+}$e $\mathrm{H}^{+}$. O produto dessas reações é o glutamato que, pelo ciclo de Krebs, irá se transformar em succinato, formando ATP por intermédio do complexo II da cadeia transportadora de elétrons (PHANG et al., 2008; PHANG; PANDHARE; LIU, 2008).Todavia, o resultado acima sugere que durante a oxidação de prolina, a PRODH pode transferir elétrons para a cadeia respiratória via redução do cofator FAD, já que a PRODH de T. cruzi está diretamente associada à membrana interna mitocondrial.

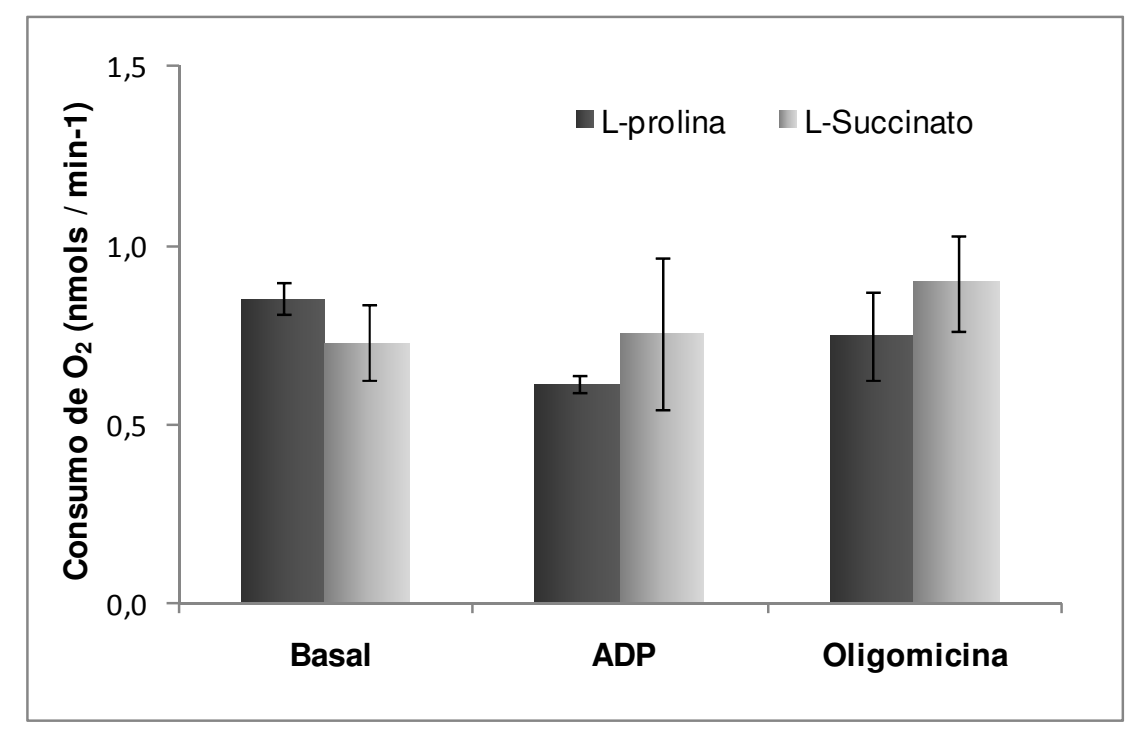

Figura 39. Taxas do consumo de oxigênio na presença dos substratos succinato e prolina (a nível de complexo II). Antes da adição de ADP (basal), na presença de ADP e oligomicina. 
Para confirmar que o perfil de consumo de $\mathrm{O}_{2}$ medido nas frações mitocondriais era devido à prolina adicionada, e não por causa de uma possível quantidade de prolina remanescente na luz das frações mitocondriais obtidas, foram realizadas medidas de prolina livre em extratos totais e frações mitocondriais de epimastigotas de T. cruzi. Foi observado que a quantidade de prolina livre na fração mitocondrial é pequena quando comparada com o extrato total, provavelmente devido ao vazamento de prolina livre durante o processo de purificação das frações (Figura 40). Esses resultados confirmam que o funcionamento da cadeia respiratória é devido principalmente ao suprimento de prolina exógena (em torno de $5 \mathrm{mM}$ ).

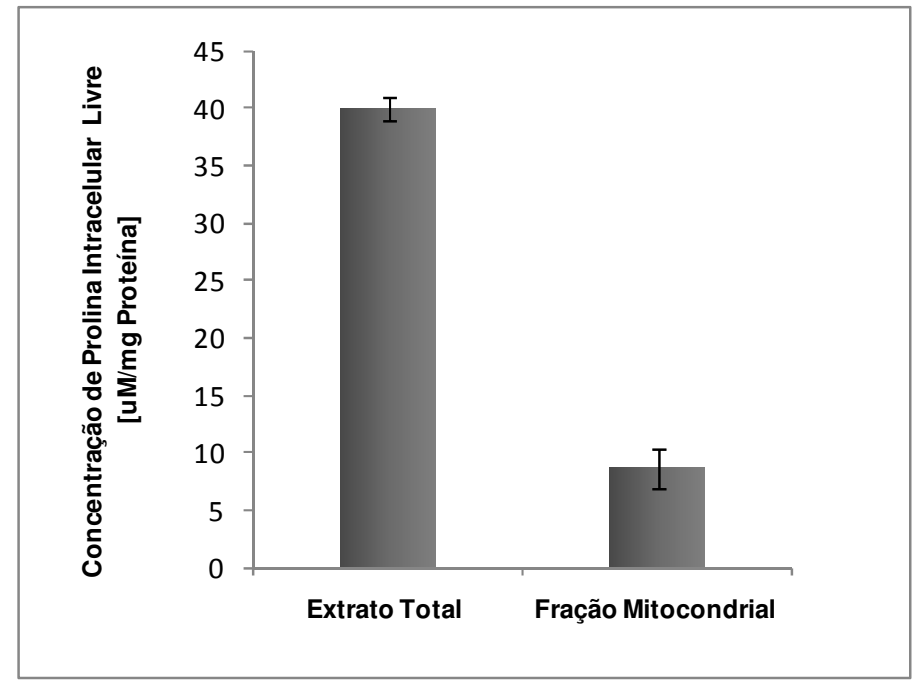

Figura 40. Concentração de prolina intracelular livre. A concentraçãode prolina foi medida tanto na fração mitocondrial purificada quanto em extrato total de epimastigotas de T. cruzi. 


\section{DISCUSSÃO}

\subsection{Atividade da PRODH de T. cruzi}

Como já relatado anteriormente, a L-prolina é uma fonte de energia relevante em tripanossomatídeos. Esse aminoácido, em T. cruzi, assim como na maioria das outras células eucariotas é metabolizado e convertido nos cinco intermediários do ciclo de Krebs (citrato, isocitrato, malato, succinato e oxaloacetato). Esse processo ocorre através de sua oxidação a glutamato em dois passos sucessivos. Primeiramente, ocorre a oxidação de prolina a P5C-GSA, pela enzima PRODH. O segundo passo consiste na conversão de P5C-GSA em glutamato, pela enzima P5CDH. O glutamato por sua vez é desaminado, entrando no Ciclo de Krebs como $\alpha$-cetoglutarato (TANNER, 2008). A prolina também está envolvida em muitos processos que são essenciais para a biologia do parasito (SILBER et al., 2005), tais como a sua diferenciação celular do parasito, tanto no inseto vetor (CONTRERAS et al., 1985) quanto nas células de mamíferos (TONELLI et al., 2004), ou ainda a participação da prolina como fonte de energia na invasão da célula hospedeira (MARTINS et al., 2009). Devido à relevância desse aminoácido em diversos processos celulares em $T$. cruzi, é de interesse do nosso laboratório a identificação dos genes envolvidos em seu metabolismo.

Inicialmente o gene PRODH de T. cruzi foi identificado no banco de dados do genoma de $T$. cruzi, clonado e utilizado em ensaios de avaliação funcional por complementação de levedura e expressão em E. coli. A atividade oxirredutase da PRODH foi confirmada bioquimicamente em extratos totais e de frações mitocondriais de epimastigotas de $T$. cruzi, e de extratos da levedura complementada e pela medição da atividade da proteína recombinante.

O gene da PRODH de T. cruzi codifica uma seqüência de 566 resíduos de aminoácidos, com massa molecular predita de aproximadamente $65 \mathrm{kDa}$. Ao compararmos as seqüências de aminoácidos da PRODH de T. cruzi com as de diferentes organismos, a PRODH de T. cruzi mostrou alta identidade com a de T. brucei, como esperado. Por sua vez, quando as seqüências de aminoácidos de ambas as espécies foram comparadas com a PRODH (Put A) de E. coli (com estrutura protéica já conhecida), observamos a presença de aminoácidos envolvidos na ligação ao cofator (FAD) e ao substrato (prolina). Adicionalmente, em ensaios de atividade realizados com a enzima PRODH recombinante de $T$. cruzi, não foi observada atividade PRODH em reações utilizando $\mathrm{NAD}^{+}$e NADP ${ }^{+}$como cofatores. Por outro lado, a enzima mostrou-se ativa na 
presença do cofator FAD. Esses fatos mostram que a PRODH de T. cruzi é uma L-prolina oxidorredutase dependente de $\mathrm{FAD}$, e sugerem que o mecanismo enzimático entre as enzimas de E. coli e tripanossomatídeos está bem conservado.

Trabalhos de mutação sítio-dirigida na PRODH de E. coli mostraram que a maior especificidade da PRODH pela prolina é devido à presença do aminoácido $\mathrm{Tyr}^{540}$, pois a substituição desse resíduo por uma serina aumentou a eficiência catalítica por hidroxiprolina (trans-4-hydroxi-L-prolina) e diminuiu a especificidade por prolina (OSTRANDER et al., 2009). Os aminoácidos descritos como responsáveis pela ligação ao substrato $\left(\mathrm{Asp}^{370}, \mathrm{Leu}^{513}, \mathrm{Tyr}^{540}\right.$ ), em especial o aminoácido determinante $\mathrm{Tyr}^{540}$, estão presente na PRODH de T. cruzi, assim como nas de outros organismos. Esse dado está de acordo com os resultados observados neste trabalho, os quais mostraram que a PRODH recombinante de $T$. cruzi é capaz de catalisar a desidrogenação de L-prolina, mas não a de substratos como hidroxiprolina ou D-prolina.

\subsection{Análises in silico do domínio putativo EF- hand presente na PRODH de T. cruzi}

A partir da seqüência de aminoácidos da PRODH de T. cruzi foi realizada uma varredura in silico para identificar domínios ou motivos característicos para modificações pós-traducionais e possíveis sinais de localização subcelular. Dessa maneira, foi identificada a presença de um potencial domínio EF-hand na PRODH de T. cruzi, o que nos permitiu inferir que, caso esse domínio fosse funcional, o mesmo faria da PRODH uma proteína regulável por $\mathrm{Ca}^{2+}$. Se essa hipótese fosse confirmada, poderíamos relacionar a atividade a outros processos dependentes de $\mathrm{Ca}^{2+}$ já descritos na literatura, tais como a resposta a estresse oxidativo (ERMAK; DAVIES, 2002) e osmótico (LEE et al., 2004).

Os domínios EF-hand foram originalmente descritos por Kretsinger e Nockolds (1973) em parvalbumina. Esses domínios assumem uma conformação com duas $\alpha$-hélices ladeando uma alça, que é definida como a região responsável pela ligação ao íon. Dentro dessa alça são bem conservados os seis aminoácidos cujas cadeias laterais participam da coordenação do íon. Esses resíduos estão na posição 1(X), 3(Y), 5(Z), 7(-X), 9 (-Y) e 12(-Z) (KAWASAKI; KRETSINGER, 1994). A coordenação do íon pode ser pentagonal com 7 uniões de coordenações (na ligação de $\mathrm{Ca}^{2+}$ ) ou octaédrica, com 6 uniões de coordenações (quando o sítio liga a $\mathrm{Mg}^{2+}$ ) (STRYNADKA; JAMES, 1989; LEWITBENTLEY; RETY, 2000). 
No caso especifico da PRODH de T. cruzi, a posição $1(\mathrm{X})$ é ocupada por um aspartato (D), o que acontece em 98\% dos casos (DA SILVA; REINACH, 1991). Já na posição $3(\mathrm{Y})$ pode ser observada uma lisina $(\mathrm{K})$, embora essa posição seja ocupada na maior parte dos casos por um aspartato ou asparagina (MARSDEN; SHAW; SYKES, 1990), indicando que nesta posição a carga não é crítica. Na literatura os resíduos mais comuns que ocupam a posição $5(Z)$ são aspartato, asparagina, serina ou glicina (STRYNADKA; JAMES, 1989). Porém, como essa posição faz ponte de hidrogênio com a posição 9(-X), seja como aceptor ou doador de prótons, provavelmente o glutamato presente nesta posição no EF-hand da PRODH de T. cruzi pode se ligar, através de ponte de hidrogênio, com a asparagina presente na posição 9(-X). A posição 7(-X), ocupada por uma lisina $(\mathrm{K})$, pode ser a mais variável de toda a alça, uma vez que a alça lateral fica exposta para o solvente. De fato, o resíduo lisina é o mais freqüente nessa posição. Além das posições comentadas acima, são bem conservados os aminoácidos hidrofóbicos na posição 8 (isoleucina, leucina e valina) e uma glicina na posição 6, que favorece o correto dobramento da alça e participa da formação de pontes de hidrogênio que contribuem para a estabilidade do sítio (GIFFORD; WALSH; VOGEL, 2007). Na PRODH de T. cruzi, essas posições são ocupadas por valina e glicina, respectivamente. A posição 12(-Z) é ocupada por um glutamato na grande maioria dos casos, porém em algumas proteínas é substituído por um aspartato (DA SILVA; REINACH, 1991). Acredita-se que essa posição seja a responsável pela especificidade do sítio, já que a coordenação do $\mathrm{Ca}^{2+}$ é realizada de forma bidentada (com os dois oxigênios da carboxila lateral), enquanto que a coordenação do $\mathrm{Mg}^{2+}$ é feita de forma monodentada (com apenas um oxigênio). A substituição dos resíduos de carga negativa na posição 12 por um aminoácido não negativo pode diminuir a afinidade do domínio por íons divalentes. Foi observada nesses casos a inativação do sítio (STRYNADKA; JAMES, 1989).

O fato da posição 12 (-Z) da PRODH de T. cruzi ser ocupada por uma glutamina (Q) precisa ser melhor analisado, já que alguns trabalhos mostram que a substituição do glutamato por uma serina ou glutamina (que é o caso) acarreta a perda de um oxigênio. Isto poderia diminuir afinidade do $\mathrm{Ca}^{2+}$ pelo sítio, ou até mesmo favorecer a ligação ao $\mathrm{Mg}^{2+}$ ( GIFFORD; WALSH; VOGEL, 2007). Todavia, Schulz et al., (1979) propuseram que devido à similaridade estrutural e de hidrofobicidade entre o ácido glutâmico e a glutamina, espera-se que haja uma interferência mínima na posição $12(-Z)$ da $E F$-hand nessa troca. Os aminoácidos presentes nas posições 3(Y) e 12(-Z) podem ser críticos para 
uma ligação ao íon $\mathrm{Ca}^{2+}$, sugerindo que este domínio tem baixa afinidade por $\mathrm{Ca}^{2+}$ ou até mesmo pode se ligar a $\mathrm{Mg}^{2+}$. Na literatura tem sido descritas algumas proteínas com domínios $E F$-hand não canônicos, em que a substituição de ácido glutâmico por lisina é compensada por outros resíduos de ácido glutâmico capazes de coordenar a ligação ao $\mathrm{Ca}^{2+}$ (HOUDUSSE, SILVER; COHEN, 1996). Além disso, outros estudos demonstraram que mutações nos resíduos de aminoácidos que são importantes na ligação a cátions divalentes podem não ter efeito na inativação do domínio $E F$-hand, mas essa inativação pode ocorrer a nível estrutural (PETERSON et al., 2000).

\subsection{Análise funcional do domínio $E F$-hand: a possível regulação da PRODH de $T$. cruzi por $\mathrm{Ca}^{2+}$ ou $\mathrm{Mg}^{2+}$}

A detecção em membranas de Western blotting de uma banda com tamanho correspondente à PRODH recombinante de T. cruzi através do agente fluorescente Quin2 indicou a presença de um domínio EF-hand funcional. O Quin-2 é um ácido tetracarboxílico, derivado de quinolina, com propriedade de ligação a metais divalentes e com capacidade de se ligar com maior afinidade a $\mathrm{Ca}^{2+}$ que a $\mathrm{Mg}^{2+}$. O resultado dessa ligação pode ser observado por absorção ultravioleta e fluorescência (TSIEN; POZZAN; RINK, 1982; LAKOWICZ et al., 1992). Uma vez demonstrada a capacidade ligante de um metal divalente à proteína $\mathrm{PRODH}$, foi analisada a possível regulação da atividade PRODH da proteína recombinante na presença de quelantes de íons divalentes (EDTA e EGTA). Os resultados obtidos sustentam a presença de um domínio EF-hand funcional na PRODH de T. cruzi com potencialidade para regular a atividade protéica. Deve-se salientar que ambos os quelantes demonstraram atividade inibitória, o que não permitiu

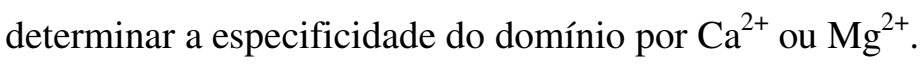

Outras enzimas mitocondriais que apresentam domínios EF-hand, como FADglicerol desidrogenase e piruvato desidrogenase de mamíferos mostraram perfís similares aos descritos aqui para a PRODH de T. cruzi. Nesses casos, foi verificado que as atividades dessas enzimas eram inibidas por ambos os quelantes de íons divalentes, EDTA e EGTA (HANSFORD; CHAPPELL, 1967; DENTON; RANDLE; MARTIN, 1972). Posteriormente, foi mostrado que o $\mathrm{Ca}^{2+}$ ativa FAD-glicerol desidrogenase com diminuição do seu Km (HANSFORD, 1991; MACDONALD; BROWN, 1996). Finalmente, foi demonstrado que a piruvato desidrogenase seria sensível a concentrações micromolares de $\mathrm{Ca}^{2+}$ e milimolares de $\mathrm{Mg}^{2+}$ (TEAGUE et al., 1982; TURKAN; HIROMASA; ROCHE, 2004). Assim, estudos mais detalhados da inibição da PRODH 
recombinante na presença dos agentes quelantes EDTA e EGTA são necessários para a melhor compreensão deste mecanismo regulatório. É interessante ressaltar que além da PRODH de T. cruzi, uma análise preliminar in silico mostrou a presença deste tipo de domínio apenas nas PRODHs de L. major e L.mexicana (dados não mostrados), e não há dados na literatura sobre a presença deste tipo de domínios em nenhuma outra PRODH estudada até agora.

Em parasitos apicomplexos e tripanossomatídeos há evidências bioquímicas da entrada e saída de $\mathrm{Ca}^{2+}$ mitocondrial (VERCESI; DOCAMPO; MORENO, 1992; XIONG, et al., 1997; UYEMURA et al., 2000; MORENO; DOCAMPO, 2003). Em T. cruzi especificamente, foi demonstrado que a adição de $\mathrm{Ca}^{2+}$ desencadeia a estimulação do ciclo respiratório (DOCAMPO; VERCESI, 1989). Posteriormente, foi observado que em formas epimastigotas de T. cruzi, o acúmulo de $\mathrm{Ca}^{2+}$ na mitocôndria pode alterar a dissipação do potencial de membrana, causando a diminuição da respiração celular e a produção de EROs, o que pode desencadear a morte celular programada dessas células (IRIGOIN et al., 2009). O papel do $\mathrm{Ca}^{2+}$ na regulação de enzimas mitocondriais em tripanossomatídeos, ainda precisa ser investigado.

Como mencionado acima, em células de mamíferos há desidrogenases mitocondriais ativadas por $\mathrm{Ca}^{2+}$. A FAD-glicerol fosfato desidrogenase está localizada na membrana interna mitocondrial e é influenciada pelas mudanças nas concentrações de $\mathrm{Ca}^{2+}$ no citoplasma. As outras três desidrogenases $\mathrm{Ca}^{2+}$ dependentes estão localizadas na matriz mitocondrial. Vários estudos utilizando essas enzimas mostraram que a ativação dessas enzimas por $\mathrm{Ca}^{2+}$, contribui no suprimento de ATP sob condições em que há aumento da demanda de energia nestas células. Assim, o $\mathrm{Ca}^{2+}$ parece estar envolvido na regulação conjunta dessas enzimas e, portanto, na cadeia respiratória e no estado energético da célula (DENTON, 2009; GRIFFITHS; RUTTER, 2009).

Ao contrário do que acontece em vertebrados, essas mesmas enzimas em $T$. cruzi parecem não ser reguladas por $\mathrm{Ca}^{2+}$. No genoma do $T$. cruzi foram identificadas as subunidades putativas $\alpha$ e $\beta$ da piruvato desidrogenase (BUSCAGLIA et al., 1996), os genes putativos para 2-oxoglutarato desidrogenase, FAD-glicerol fosfato desidrogenase e isocitrato desidrogenase NADP ${ }^{+}$dependente (ADROHER; OSUNA; LUPIANEZ, 1988). Todavia, análises in silico das seqüências protéicas dessas enzimas mostraram que não há domínios EF-hand nas mesmas (dados não mostrados). Somente a FAD-glicerol fosfato desidrogenase apresentou uma região putativa de ligação a $\mathrm{Zn}^{2+}$. Porém, é importante 
ressaltar que o fato de que em $T$. cruzi não tenham sido encontrados domínios de ligação a $\mathrm{Ca}^{2+}$ nessas enzimas, não significa que outras desidrogenases não possam ser reguladas por íons divalentes. Esses fatos em conjunto poderiam estar sinalizando uma lógica particular na regulação das enzimas mitocondriais de tripanossomatídeos. Assim, o papel do $\mathrm{Ca}^{2+}$ intramitocondrial na regulação de desidrogenases mitocondriais em protozoários ainda precisa ser elucidado.

\subsection{Localização e perfil da PRODH de T. cruzi ao longo do ciclo de vida}

A localização subcelular da enzima foi avaliada por imunofluorêscencia indireta. Nesse ensaio a PRODH foi co-localizada com um marcador mitocondrial (MitoTracker) em todos os estágios do ciclo de vida do T. cruzi. A distribuição subcelular da enzima PRODH foi validada através de ensaios de permeabilização de epimastigotas de $T$. cruzi com diferentes concentrações de digitonina. O perfil de extração obtido foi monitorado por Western Blotting e atividade PRODH nas diferentes frações. Os resultados obtidos mostraram a presença da enzima nas frações resistentes a digitonina.

As análises in silico da PRODH de T. cruzi também mostraram a presença de uma seqüência de direcionamento mitocondrial e três seqüências que corresponderiam aos domínios transmembranas. As regiões de direcionamento mitocondrial são compostas na maior parte dos casos, por sequiências de aminoácidos amino ou carboxi-terminais de aproximadamente 20-60 resíduos. Essas regiões contêm um número significativo de aminoácidos positivos (alto número de resíduos de Arg, Ala e Ser), resíduos hidroxilados, e baixo ou inexistente conteúdo de aminoácidos negativos (Asp e Glu) (CLAROS; BRUNAK; VON HEIJNE, 1997).

A estrutura secundária dessas regiões é constituída por $\alpha$-hélices anfipáticas (anfifílicas), aminoácidos hidrofóbicos distribuídos de um lado da hélice e aminoácidos carregados positivamente do outro. Uma vez que as proteínas são internalizadas na mitocôndria, essas seqüências são removidas por proteases específicas, assegurando a manutenção da proteína importada para a mitocôndria (NEUPERT, 1997). Por isso, cerca de $60 \%$ dessas seqüências de endereçamento mitocondrial têm um resíduo de Arg na posição -2 ou -3 relacionado ao sítio de clivagem (SCHNEIDER et al., 1998; CHOU et al., 1999). Todas essas características constituem elementos importantes para o reconhecimento específico da maquinaria de importação mitocondrial (LEMIRE et al., 1989). 
A região de direcionamento mitocondrial na porção $\mathrm{N}$-terminal da PRODH de $T$. cruzi possui todas as características acima relatadas: como a presença majoritária de aminoácidos básicos; a arginina próxima ao sítio de clivagem; e uma estrutura secundária que forma uma $\alpha$-hélice anfipática. Esse fato, em conjunto com as evidências experimentais, sustenta a idéia de que a enzima PRODH de T. cruzi está presente na membrana mitocondrial e é dependente de FAD, características já observadas em PRODH de bactérias, plantas e animais (ADAMS; FRANK, 1980).

\subsection{Perfil de expressão do gene PRODH}

Os dados obtidos nas análises da PRODH em todo o ciclo de vida de $T$. cruzi, tanto por RT-PCR como por western blotting, mostraram uma maior quantidade de mRNA e expressão protéica na forma epimastigota intracelular e menores na forma amastigota. Esses resultados estão de acordo com trabalhos anteriores que demonstram que o metabolismo de prolina é fundamental para a progressão da metaciclogênese e do ciclo intracelular (CONTRERAS et al., 1985; HOMSY et al., 1989; TONELLI et al., 2004).

Recentemente foi estabelecido por nosso grupo que existe uma correlação entre a variação da atividade do transporte de glicose, do transporte de prolina e a concentração de prolina livre intracelular, ao longo do ciclo do parasito no hospedeiro mamífero (Figura 41) (SILBER et al., 2009). Nas formas amastigotas, onde o transporte de prolina é baixo e os níveis de prolina intracelular são altos $(8,09 \mathrm{mM})$, aparentemente há um consumo apenas de prolina estocada durante a replicação e/ou diferenciação para o estágio epimastigota intracelular, e conseqüentemente menor atividade PRODH. Já a forma epimastigota intracelular, a qual apresenta os menores níveis de prolina intracelular livre $(0,45 \mathrm{mM})$ e depende do suplemento externo de prolina, diferencia-se em tripomastigotas (TONELLI et al., 2004; SILBER et al., 2009). Interessantemente, a expressão da enzima PRODH acompanha a atividade de transporte, sustentando a hipótese de que as formas epimastigotas intracelulares são metabolicamente dependentes do suprimento externo e do metabolismo deste aminoácido. 


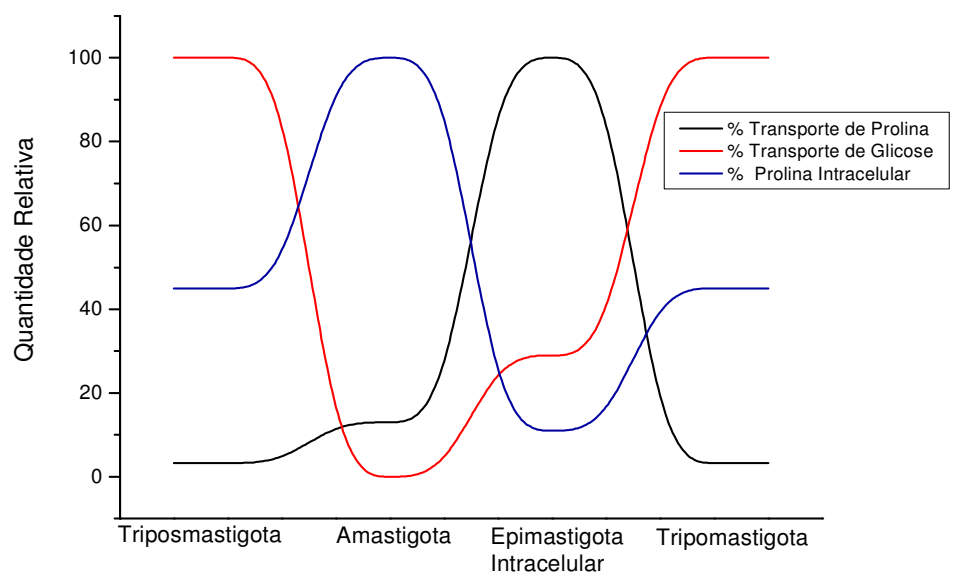

Figura 41. Variações relativas das atividades dos transportadores de glicose e prolina e concentrações de prolina intracelular livre durante o ciclo de vida do ciclo de vida do $T$. cruzi

FONTE: Silber et al. (2009).

\subsection{Complementação de levedura com PRODH de T.cruzi}

A levedura Saccharomyces cerevisiae é um dos melhores sistemas estabelecidos para complementação heteróloga devido ao conhecimento da sua fisiologia e genética, e por existirem disponíveis mutantes auxotróficos que favorecem a manutenção de plasmídeos com marcadores seletivos (Porro et al., 2005). Esse sistema foi utilizado no presente trabalho em ensaios de complementação com o gene PRODH de T. cruzi. Para isso, foi utilizada uma cepa auxotrófica de S. cerevisiae (BY4741), com uma deleção para o gene PRODH. Essa cepa tem o nome sistemático YLR142W, mas usualmente é chamada $\triangle P U T 1$.

$\mathrm{Na}$ literatura tem sido descrito que a levedura mutante $\triangle P U T 1$ pode restaurar seus níveis de prolina interna via degradação de arginina e $\alpha$-cetoglutarato, mas não é capaz de metabolizar prolina (MORITA; NAKAMORI; TAKAGI, 2002). Portanto, a levedura $\triangle P U T 1$ é incapaz de crescer em meios que possuem prolina como única fonte de nitrogênio. A levedura $\triangle P U T 1$ complementada com o gene PRODH de $T$. cruzi, teve restabelecida a sua capacidade de oxidar prolina a P5C, mostrando que o produto desse gene é capaz de catalisar esta reação. Essa complementação foi confirmada pela detecção do transcrito e da proteína PRODH de T. cruzi, e também pela medição da atividade PRODH em extratos totais da levedura complementada. 


\subsection{Participação da PRODH em mecanismos de resistência a estresse oxidativo}

A levedura $\triangle P U T 1$ complementada com a PRODH de T. cruzi, quando submetida a estresse oxidativo, apresentou menor taxa de viabilidade celular comparada com a cepa nocaute e controle. Da mesma forma, os epimastigotas de T. cruzi, quando incubados previamente em meio contendo prolina como fonte de carbono, mostraram uma maior resistência ao estresse oxidativo do que quando foram pré-incubados com outras fontes como glicose e glutamato. Também foi mostrado que a maior resistência ao estresse oxidativo pode ser correlacionada com a maior quantidade intracelular de prolina livre, tanto nas formas epimastigotas de $T$. cruzi quanto nas leveduras submetidas a estresse oxidativo.

Estes dados sugerem que a expressão heteróloga da PRODH de $T$. cruzi na levedura tornou as células mais susceptíveis ao estresse oxidativo, devido ao fato que a presença da enzima, causou uma diminuição na concentração de prolina intracelular livre. Além disso, demonstrou mais uma vez a funcionalidade da complementação. Em alguns trabalhos foi observado, em leveduras, que os baixos níveis de prolina em linhagens capazes de expressar o gene PUTl (PRODH) intensificaram as EROs, enquanto que em leveduras mutantes de PUT1, houve uma correlação do alto conteúdo de prolina com o aumento da proteção ao estresse oxidativo (CHEN et al., 2006) e térmico (TAKAGI et al., 2000; MORITA; NAKAMORI; TAKAGI, 2002). Neste sentido, foi relatado que o acúmulo de prolina intracelular pode diminuir os níveis de EROs em fungos, prevenindo assim, a morte celular programada (CHEN; DICKMAN, 2005). Também foi descrito que a prolina modula o estado redox intracelular e protege células de mamíferos do estresse oxidativo (KRISHNAN; BECKER, 2006).

Durante o seu ciclo de vida, o T. cruzi é exposto a diferentes EROs gerados pelo metabolismo aeróbico do parasito, na resposta imune do hospedeiro e por medicamentos utilizados no tratamento da doença de Chagas (TURRENS, 2004). No entanto, nos tripanossomatídeos, faltam sistemas antioxidantes importantes que são encontrados em outros organismos (tioredoxina, catalase e glutationa). Todavia, os mesmos apresentam um sistema de detoxificação único que é baseado em enzimas tiol tripanotiona e tripanotiona redutase (KRAUTH-SIEGEL; COMINI, 2008). Além dessas enzimas, alguns trabalhos têm relacionado outras enzimas na defesa do T. cruzi contra o estresse oxidativo. A glicose-6-fosfato desidrogenase, por exemplo, tem seu perfil de expressão aumentado em tripomastigotas metacíclicos, mas não em epimastigotas, em resposta a 
estresse oxidativo gerado por $\mathrm{H}_{2} \mathrm{O}_{2}$ (IGOILLO-ESTEVE et al., 2007). Da mesma forma, a arginina quinase, quando superexpressa em epimastigotas de T.cruzi, aumenta significativamente a capacidade de sobrevivência desses parasitos durante a exposição a $\mathrm{H}_{2} \mathrm{O}_{2}$ (MIRANDA et al., 2006).

Os dados apresentados neste trabalho sugerem que a PRODH também pode exercer um papel importante em mecanismos de resistência ao estresse oxidativo em $T$. cruzi, ao manter a sua expressão em níveis que favoreça a concentração de prolina interna livre e o balanço redox intracelular. Outros estudos têm atribuído um fator antioxidante à prolina, sugerindo que este aminoácido atua como um potencial seqüestrador de EROs, incluindo o oxigênio singlete $\left({ }^{1} \mathrm{O}_{2}\right)$ (ALIA; MOHANTY; MATYSIK, 2001; KAUL, SHARMA; MEHTA, 2008). Porém, os mecanismos envolvidos neste processo ainda não estão claros.

\subsection{Efeito de Inibidores da enzima PRODH}

O efeito de análogos de L-prolina no crescimento e viabilidade de formas epimastigotas de T. cruzi foi avaliado. Dentre estes, o análogo ácido L-tiazolidina-4carboxílico (T4C) mostrou resultados significativos na inibição do crescimento das formas epimastigotas de T. cruzi. O T4C é um produto de condensação não enzimático, contendo enxofre como um tioéter (RATNET et al., 1937). Esse composto pode ser metabolizado em bactérias e células de mamíferos (UNGER; DEMOSS, 1966; BOHLER, WAGNER; BASSLER, 1989).

Quando epimastigotas de T. cruzi foram tratados simultaneamente com T4C e prolina, foram mais sensíveis ao estresse oxidativo do que aqueles tratados apenas com prolina, mostrando um efeito sinérgico entre o tratamento com o análogo e as condições de estresse oxidativo avaliadas. Foi avaliado também o conteúdo de prolina livre intracelular nos parasitos tratados com prolina e T4C ou apenas com prolina, observandose que esse aminoácido estava em menor concentração nas células tratadas com o análogo. Esses dados, novamente correlacionam à quantidade de prolina livre intracelular com a capacidade de resistir a estresse oxidativo.

Diante disso, decidiu-se investigar se o efeito do T4C estaria relacionado com a inibição de enzimas de degradação de prolina. Verificou-se que o T4C não altera a atividade das enzimas PRODH e PR, mas pode agir como um inibidor competitivo do transporte de L-prolina. Esse efeito do T4C parece contrário ao que acontece em plantas submetidas a condições de estresse hídrico, em que se observou que o T4C inibe a 
oxidação de prolina, através da PRODH, mas não interfere no transporte de desse aminoácido para a matriz mitocondrial (ELTHON; STEWART, 1984).

Como mencionado acima, uma diminuição do conteúdo de prolina intracelular em epimastigotas de T. cruzi aumentou a sua sensibilidade a estresse oxidativo. Ao longo do ciclo de vida no hospedeiro vertebrado, o T. cruzi é submetido a estresse oxidativo por duas vias: uma natural (mecanismos de defesa de alguns tióis da célula hospedeira durante a invasão do T. cruzi) e outra artificial (quando o hospedeiro, por exemplo, o homem, e tratado com quimioterápicos como o nifurtimox e o benzonidazol). A diminuição na concentração de prolina livre intracelular em T. cruzi, como mencionado anteriormente, pode ser obtida mediante o tratamento das células com T4C, inibidor do transporte de prolina. Portanto, estes resultados nos permitem propor que o uso do T4C poderia ser combinado com nifurtimox e benzonidazol, o que permitiria diminuir as doses de uso dessas drogas (diminuindo a toxicidade do tratamento) ou aumentar a sua efetividade. Estes dados contribuem também para a validação dos transportadores como alvos relevantes para a terapia (SILBER et al., 2005; LANDFEAR, 2008).

\subsection{Participação da prolina na cadeia respiratória}

Os resultados do presente trabalho mostram que tanto succinato quanto prolina (substratos de flavoproteínas que doam elétrons) são capazes de estimular a respiração de epimastigotas de T. cruzi em vesículas mitocondriais livres de conteúdo de matriz. Esses dados dão suporte à idéia de que o metabolismo de prolina em $T$. cruzi, além de participar do Ciclo de Krebs, também pode estar envolvido diretamente na cadeia transportadora de elétrons, através a enzima PRODH.

$\mathrm{Na}$ literatura está bem descrita a participação da prolina no metabolismo energético, com a conseqüente produção de ATP em tripanossomatídeos. Em formas procíclicas de $T$. brucei, por exemplo, trabalhos recentes concluíram que, em condições onde o meio é rico em glicose, a maior parte do ATP é produzida pela fosforilação em nível de substrato. No entanto, nas condições em que o consumo de prolina é alto, o parasito depende da fosforilação oxidativa para a produção de ATP (LAMOUR et al., 2005; COUSTOU et al., 2008). Como mencionado anteriormente, Martins et al. (2009) demonstraram que tripomastigotas metacíclicos requerem energia para o processo de invasão, e esta energia e suprida pela prolina, já que este metabólito é capaz de restabelecer rapidamente os níveis de ATP após um período de jejum de até 4 horas. 
Esses dados indicam que a oxidação de prolina é capaz de fornecer o ATP necessário para sustentar o processo de infectividade do parasito.

Em T. cruzi, a prolina participa do metabolismo energético através da geração de succinato. A prolina gera $\alpha$-cetoglutarato, o qual participa do Ciclo de Krebs (EVANS; BROWN, 1972; TURRENS, 1989). Contudo, a participação da PRODH diretamente na cadeia respiratória no mesmo nível do complexo II ainda não tinha sido investigada. Algumas características da PRODH, como o fato dessa enzima oxidar FAD e possuir localização mitocondrial, confirmam essa proposta.

Além disso, vários trabalhos com outros organismos sugeriram que a PRODH pode doar elétrons derivados do processo de oxidação de prolina diretamente para a cadeia transportadora de elétrons (HANSFORD; SACKTOR, 1970; ADAMS; FRANK, 1980; ELTHON; STEWART, 1982; ABRAHAMSON et al., 1983; WOOD, 1987; MILLER et al., 2009). Esses trabalhos propuseram que o mecanismo catalítico da enzima PRODH envolve a transferência de elétrons do substrato prolina para o cofator FAD, que por sua vez, é reduzido pelo complexo II da cadeia transportadora de elétrons. Esse fato permite propor que a PRODH poderia transferir elétrons para a cadeia respiratória, no mesmo nível que o complexo II. Porém, no caso da PRODH de T. cruzi, foi mostrado que o citocromo $\mathrm{C}$ pode funcionar como aceptor de elétrons provenientes da PRODH, elétrons que suportariam a geração de ATP (ADAMS; FRANK, 1980; ABRAHAMSON et al., 1983)

A PRODH de T. cruzi pode reduzir o citocromo $\mathrm{C}$, como demonstrado nas reações de atividade utilizando o citocromo $\mathrm{C}$ como agente aceptor de elétrons (oxidante). Porém, esses dados são insuficientes para sugerir uma posição específica deste processo na cadeia de transporte de elétrons, assim como o percurso dos mesmos. No caso da succinato desidrogenase, os prótons e elétrons presentes no succinato são transferidos ao complexo II através de $\mathrm{FAD}$, que se reduz a $\mathrm{FADH}_{2}$. Dessa forma são transferidos elétrons para a coenzima Q, passando pelo caminho comum, complexo III, citocromo c, complexo IV e oxigênio (THOMSON; KLIPFEL, 1960). Já em $S$. cerevisiae, a oxidação de prolina, via Put 1p (PRODH), está diretamente ligada à redução de ubiquinona, complexo III, na cadeia transportadora de elétrons (WANDURAGALA et al., 2010), da mesma forma que em bactérias, plantas e animais. Nesses organismos, diferentes desidrogenases (incluindo a PRODH) transferem elétrons para a ubiquinona, 
estimulando o consumo de oxigênio e redução de citocromo C (RASMUSSON; GEISLER; MOLLER, 2008).

\subsection{A via prolina-glutamato em $T$. cruzi: uma proposta}

A PRODH e a P5CDH são enzimas mitocôndrias que usam FAD e $\mathrm{NAD}^{+}$como aceptores de elétrons e podem gerar $\mathrm{FADH}_{2}$ e $\mathrm{NADH}+\mathrm{H}^{+}$, respectivamente. Este processo libera elétrons que contribuem com a geração do gradiente de $\mathrm{H}^{+}$através da membrana interna mitocondrial, e eventualmente para o processo de respiração e fosforilação oxidaiva (SZABADOS; SAVOURE, 2010). O P5C produzido via PRODH é um metabólito intermediário chave entre as vias da prolina, ornitina e glutamato, além de estar envolvido no metabolismo energético e na homeostase redox celular em muitos organismos eucariotos (PHANG, 1985; PHANG et al., 2008).

O P5C pode ser convertido a glutamato e $\alpha$-cetoglutarato para gerar intermediários do Ciclo de Krebs (PHANG, 1985). Além disso, alguns trabalhos sugerem que durante a formação de P5C via P5CR (NADPH dependente) há uma interligação metabólica da via prolina-glutamato com a via das pentoses fosfato (VPP). Esta interligação aconteceria através da transferência de potenciais redutores da VPP para a mitocôndria, favorecendo a geração ATP (PHANG, DOWNING; YEN, 1980; HAGEDORN; PHANG, 1983; 1986; KOHL et al., 1990; SARKAR et al., 2009) ou EROs (LIU et al., 2005; WHITE et al., 2007). O glutamato semialdeído (GSA) formado neste processo metabólico, além de ser convertido espontaneamente a P5C, também pode ser substrato da OAT, participando assim do ciclo da uréia (PHANG; DOWNING; YEN, 1980; PHANG et al., 2008; TANNER, 2008).

Sendo assim, na maior parte dos eucariotos, o ciclo prolina-glutamato pode interconectar vários processos metabólicos como a cadeia transportadora de elétrons, a via pentose fosfato, o ciclo de Krebs e o ciclo da uréia (Figura 42). Com exceção da enzima OAT do Ciclo da uréia (ausente em T. cruzi), no banco de dados do genoma de $T$. cruzi foram encontradas seqüências correspondentes a todas as enzimas da via prolinaglutamato, como a P5CR (Tc00.1047053506857.20), P5CS (Tc00.1047053511023.10), P5CDH (Tc00.1047053509351.10) e a PRODH (Tc00.1047053506411.30) (presente trabalho). Todas essas enzimas tem sido objeto de estudos em nosso laboratório, e a relação de cada uma delas com os processos acima citados estão começando a ser elucidados. 

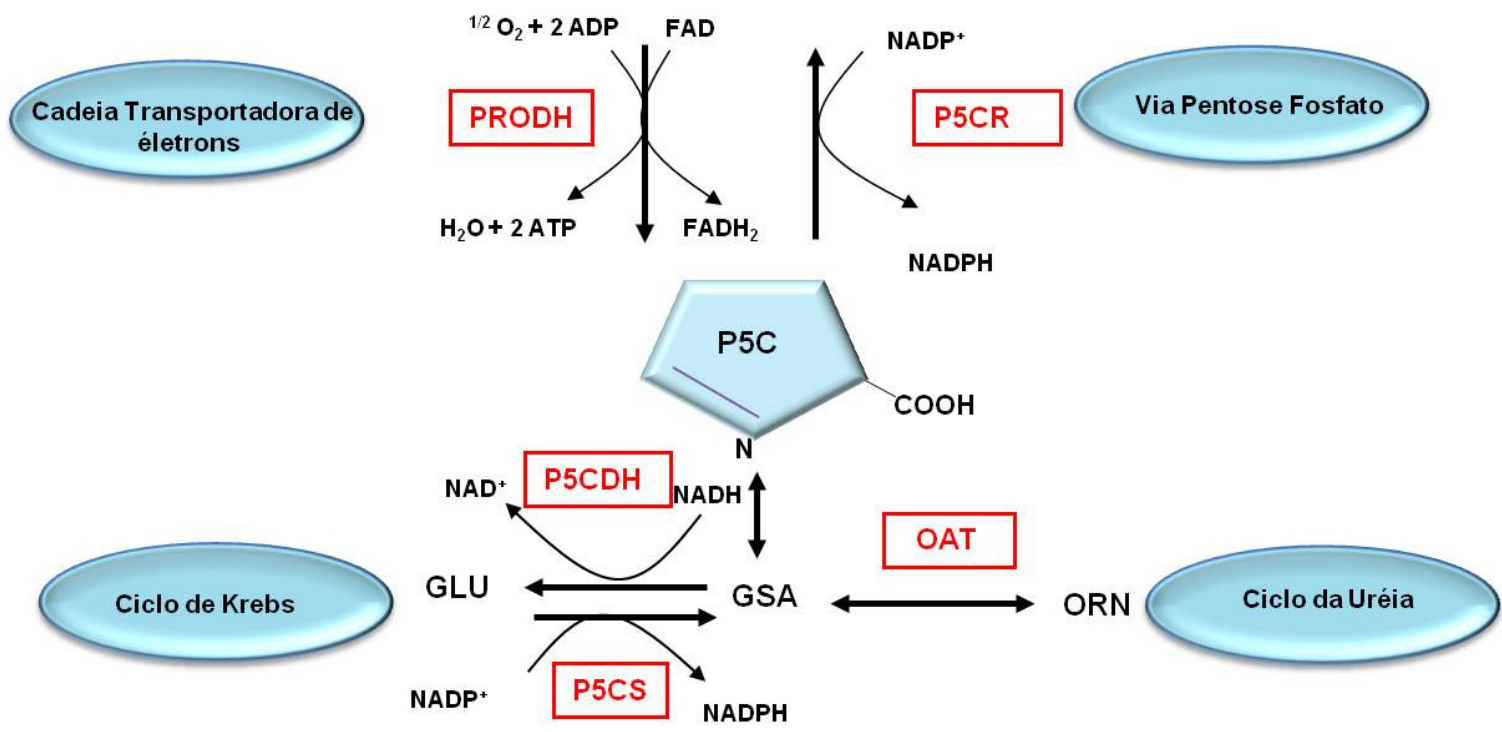

Figura 42. Participação da prolina em outras vias metabólicas. A oxidação de prolina via PRODH, pode transferir elétrons para a cadeia transportadora de elétrons, e produzir P5C e GSA, que por sua vez são transformados em glutamato, via P5CDH, e posteriormente em $\alpha$-cetoglutarato entrando no Ciclo de Krebs. O glutamato também pode ser novamente reduzido a GSA via P5CS, e o GSA transformado em ornitina via OAT (reação reversível), participando do Ciclo da Uréia. No catabolismo de prolina, a P5CR transforma P5C em prolina e os cofatores reduzidos podem participar da Via Pentose Fosfato. 


\section{CONCLUSÕES}

O genoma de T. cruzi fornece uma matriz de leitura aberta (ORF) de pelo menos

$1,7 \mathrm{~Kb}$ que codifica para uma prolina desidrogenase (PRODH) (Tc00.1047053506411.30);

$\checkmark$ A enzima de PRODH de T. cruzi é transcrita, expressa e ativa;

$\checkmark$ Os níveis de prolina intracelular podem ser correlacionados com a resistência a estresse oxidativo, fato que foi demonstrado tanto em mutantes de leveduras complementadas com o gene PRODH de T. cruzi quanto com os nocautes. Estes estudos foram confirmados em formas epimastigotas de $T$. cruzi utilizando inibidores do transporte de prolina;

$\checkmark$ O perfil de expressão apresentado pelo gene em experimentos de RT-PCR quantitativo e da proteína por western blotting, com maior atividade na forma epimastigota intracelular e menor na forma amastigota, indica que a PRODH é regulada de maneira concertada com o transporte de prolina ao longo do ciclo do

$\checkmark$ A enzima PRODH recombinante possui $\mathrm{K}_{\mathrm{m}}=16,58 \mu \mathrm{M}$ e $\mathrm{V}_{\max }$ de $0,066 \mu \mathrm{mol} / \mathrm{min} / \mathrm{mg}$;

$\checkmark$ A PRODH tem peso molecular aparente de $65 \mathrm{kDa}$ e localização mitocondrial;

$\checkmark$ A PRODH é FAD-dependente e pode utilizar Citocromo C como aceptor de elétrons;

$\checkmark$ A PRODH de T. cruzi é a primeira descrita a apresentar um sítio funcional de ligação de $\mathrm{Ca}^{2+}$ ou $\mathrm{Mg}^{2+}$ e tem sua atividade regulada por esses íons;

$\checkmark$ A PRODH poderia estar participando diretamente da cadeia transportadora de elétrons em nível do complexo II;

$\checkmark$ O análogo estrutural de prolina T4C foi capaz de inibir o crescimento de epimastigotas de T.cruzi quando comparado aos outros análogos testados;

$\checkmark$ O T4C age como inibidor competitivo dos transportadores de prolina, mas não da prolina racemase nem da prolina desidrogenase, produzindo uma diminuição nos níveis de prolina livre intracelular; 
$\checkmark \mathrm{O}$ efeito sinérgico entre o tratamento com T4C e diferentes estresses, tais como oxidativo, nutricional e térmico mostram um papel relevante da prolina em relação com os mecanismos de resistência a esses estresses. De maneira geral, nas condições de estresse mencionadas, os maiores níveis de prolina interna livre podem ser correlacionados a maior viabilidade celular. 


\section{REFERÊNCIAS ${ }^{*}$}

ABRAHAMSON, J. L. L. et al. Proline dehydrogenase from Escherichia coli K12. Properties of the membrane-associated enzyme. Eur. J. Biochem., v. 134, n. 1, p. 77-82, 1983.

ADAMS, E.; FRAK, L. Metabolism of proline and the hydroxyprolines. Annu. Rev. Biochem., v. 49, p. 1005-61, 1980.

ADROHER, F. J.; OSUNA, A.; LUPIANEZ, J. A. Differential energetic metabolism during Trypanosoma cruzi differentiation. I. Citrate synthase, NADP-isocitrate dehydrogenase, and succinate dehydrogenase. Arch. Biochem. Biophys., v. 267, n. 1, p. 252-61, 1988.

AGUIRRE, G., E. et al. Design, synthesis and biological evaluation of new potent 5nitrofuryl derivatives as anti-Trypanosoma cruzi agents. Studies of trypanothione binding site of trypanothione reductase as target for rational design. Eur. J. Med. Chem., v. 39, n. 5, p. 421-31, 2004.

ALIA, P.; MOHANTY, P.; MATYSIK, J. Effect of proline on the production of singlet oxygen. Amino Acids, v. 21, n. 2, p. 195-200, 2001.

ALMEIDA-DE-FARIA et al. Trypanosoma cruzi: characterization of an intracellular epimastigote-like form. Exp. Parasitol., v. 92, n. 4, p. 263-74, 1999.

ALVES, M. J.; COLLI, W. Trypanosoma cruzi: adhesion to the host cell and intracellular survival. IUBMB Life, v. 59, n. 4-5, p. 274-9, 2007.

ANDRADE, L. O. et al. Trypanosoma cruzi: role of host genetic background in the differential tissue distribution of parasite clonal populations. Exp. Parasitol., v. 100, n. 4, p. $269-75,2002$.

ANDRADE, S. G. et al. Specific chemotherapy of Chagas disease: a comparison between the response in patients and experimental animals inoculated with the same strains. Trans. R. Soc. Trop. Med. Hyg., v. 86, n. 6, p. 624-6, 1992.

APT, W. et al. Itraconazole or allopurinol in the treatment of chronic American trypanosomiasis: the results of clinical and parasitological examinations 11 years posttreatment. Ann. Trop. Med. Parasitol., v. 99, n.8, p. 733-41, 2005.

AVILA, J. L.; AVILA, A.; MONZON, H. Differences in allopurinol and 4aminopyrazolo(3,4-d) pyrimidine metabolism in drug-sensitive and insensitive strains of Trypanosoma cruzi. Mol. Biochem. Parasitol., v. 11, p. 51-60, 1984.

AVILA, J. L.; AVILA, A.; MUNOZ, E. Effect of allopurinol on different strains of Trypanosoma cruzi. Am. J. Trop. Med. Hyg., v. 30, n. 4, p. 769-74, 1981.

\section{*De acordo com:}

Associação Brasileira de Normas Técnicas. NBR 6023: Informação e documetação: referências: elaboração. Rio de Janeiro, 2002. 
BARDERI, P. et al. The NADP+-linked glutamate dehydrogenase from Trypanosoma cruzi: sequence, genomic organization and expression. Biochem. J., v. 330 (Pt2), p. 9518, 1998.

BARRETT, M. P. The pentose phosphate pathway and parasitic protozoa. Parasitol. Today, v. 13, n. 1, p. 11-6, 1997.

BATES, L.S. Rapid determination of free proline for water-stress studies. Plant Soil, v. 39, p. 205-207, 1973.

BARRETT, M. P. et al. The trypanosomiases. Lancet, v. 362, n. 9394, p. 1469-80, 2003.

BERGMEYER, H. U. Standardization of enzyme assays. Clin. Chem., v. 18, n. 11, p. 1305-11, 1972.

BESTEIRO, S. et al. Energy generation in insect stages of Trypanosoma brucei: metabolism in flux. Trends Parasitol., v. 21, n. 4, p. 185-91, 2005.

BITTENCOURT, A. L. Possible risk factors for vertical transmission of Chagas' disease. Rev. Inst. Med. Trop., v. 34, n. 5, p. 403-8, 1992.

BODLEY, A. L.; SHAPIRO T. A. Molecular and cytotoxic effects of camptothecin, a topoisomerase I inhibitor, on trypanosomes and Leishmania. Proc. Natl. Acad. Sci., v. 92, n. 9 , p. 3726-30, 1995.

BOHLER, S.; WAGNER, K.; BASSLER, K. H. Metabolism of L-thiazolidine-4carboxylic acid. Infusionstherapie, v. 16, n. 2, p.82-6, 1989.

BOSCARDIN, S. B. et al. Chagas' disease: an update on immune mechanisms and therapeutic strategies. J. Cell Mol. Med., v. 14, p. 1373-84, 2010.

BOVERIS, A.; HERTIG, C. M.; TURRENS, J. F. Fumarate reductase and other mitochondrial activities in Trypanosoma cruzi. Mol. Biochem. Parasitol., v. 19, n. 2, p. 163-9, 1986.

BRACK, C. Electron microscopic studies on the life cycle of Trypanosoma cruzi with special reference to developmental forms in the vector rhodnius prolixus. Acta Trop., v. 25, n. 4, p. 289-356, 1968.

BRADFORD, M. M. A rapid and sensitive method for the quantitation of microgram quantities of protein utilizing the principle of protein-dye binding. Anal. Biochem., v. 72, p. 248-54, 1976.

BRAK, K. et al. Identification of a new class of nonpeptidic inhibitors of cruzain. J. Am. Chem. Soc., v. 130, n. 20, p. 6404-10. 2008.

BRENER, Z. Life cycle of Trypanosoma cruzi. Rev. Inst. Med. Trop., v. 13, n. 3, p. 171$8,1971$. 
BRENER, Z. Biology of Trypanosoma cruzi. Annu. Rev. Microbiol., v. 27, p. 347-82, 1973.

BRENER, Z. Host-parasite relations in Chagas disease: mechanisms of infection and disease. Ann. Soc. Belg. Med. Trop., v. 65, n. 1, p. 9-13, 1985.

BRENER, Z.; CHIARI, E. Observations on the chronic phase of experimental Chagas' disease in mice. Rev. Inst. Med. Trop., v. 5, p. 128-32, 1963.

BRINGAUD, F. et al. Acetate and succinate production in amoebae, helminths, diplomonads, trichomonads and trypanosomatids: common and diverse metabolic strategies used by parasitic lower eukaryotes. Parasitology, p.1-17, 2009.

BRINGAUD, F. et al. Energy metabolism of trypanosomatids: adaptation to available carbon sources. Mol. Biochem. Parasitol., v.149, n.1, Sep, p.1-9. 2006.

BROWN, G. C. Control of respiration and ATP synthesis in mammalian mitochondria and cells. Biochem. J., v. 284 (Pt1), p. 1-13, 1992.

BURLEIGH, B. A.; ANDREWS, N. W. The mechanisms of Trypanosoma cruzi invasion of mammalian cells. Annu. Rev. Microbiol., v. 49, p. 175-200, 1995.

BUSCAGLIA, C. A. et al. A putative pyruvate dehydrogenase alpha subunit gene from Trypanosoma cruzi. Biochim. Biophys. Acta, v. 1309, n. 1-2, p. 53-7, 1996.

BUSTAMANTE, J. M.; BIXBY, L. M.; TARLETON, R. L. Drug-induced cure drives conversion to a stable and protective CD8+ T central memory response in chronic Chagas disease. Nat. Med., v. 14, n. 5, p. 542-50, 2008.

CACERES, A. J. et al. Molecular and biochemical characterization of hexokinase from Trypanosoma cruzi. Mol. Biochem. Parasitol., v. 126, n. 2, p. 251-62., 2003.

CAFFREY, C. R.; SCORY, S.; STEVERDING, D. Cysteine proteinases of trypanosome parasites: novel targets for chemotherapy. Curr. Drug Targets, v. 1, n. 2, p. 155-62, 2000.

CHAGAS, C.R.J. Nova tripanosomíase humana. Estudos sobre a morphologia e o ciclo evolutivo do Schizotrypanum cruzi n. gen. n. esp., agente da nova entidade mórbida do homem. Mem. Inst. Oswaldo Cruz, v. 1, p. 159-218, 1909.

CALDAS, R. A. et al. Incorporation of ammonium in amino acids by Trypanosoma cruzi. J. Parasitol., v. 66, n. 2, p. 213-6, 1980.

CAMARGO, E. P. Growth and differentiation in Trypanosoma cruzi. I. Origin of metacyclic trypanosomes in liquid media. Rev. Inst. Med. Trop. Sao Paulo, v. 12, p. 93100, 1964.

CAMARGO, E. P. et al. Trypanosoma spp., Leishmania spp. and Leptomonas spp.: enzymes of ornithine-arginine metabolism. Exp. Parasitol., v. 46, n. 2, p. 141-4, 1978. 
CAMPETELLA, O.; MARTINEZ, J.; CAZZULO, J. J. A major cysteine proteinase is developmentally regulated in Trypanosoma cruzi. FEMS Microbiol. Lett., v. 55, n. 1-2, p. 145-9, 1990.

CANCADO, J. R. Criteria of Chagas disease cure. Mem. Inst. Oswaldo Cruz, v. 94 Suppl 1, p. 331-5, 1999.

CANCADO, J. R. Long term evaluation of etiological treatment of chagas disease with benznidazole. Rev. Inst. Med. Trop., v. 44, n. 1, p. 29-37, 2002.

CANEPA, G. E. et al. Characterization of Trypanosoma cruzi L-cysteine transport mechanisms and their adaptive regulation. FEMS Microbiol. Lett., v. 292, n. 1,p. 27-32, 2009.

CANNATA, J. J.; CAZZULO, J. J. The aerobic fermentation of glucose by Trypanosoma cruzi. Comp. Biochem. Physiol. B., v. 79, n. 3, p. 297-308, 1984a.

CANNATA, J. J.; CAZZULO, J. J. Glycosomal and mitochondrial malate dehydrogenases in epimastigotes of Trypanosoma cruzi. Mol. Biochem. Parasitol., v. 11, p. 37-49, 1984b.

CANNATA, J. J. et al. Two forms of 'malic' enzyme with different regulatory properties in Trypanosoma cruzi. Biochem. J., v. 184, n. 2, p. 409-19, 1979.

CAZZULO FRANKE et al. The NAD-linked aromatic alpha-hydroxy acid dehydrogenase from Trypanosoma cruzi. A new member of the cytosolic malate dehydrogenases group without malate dehydrogenase activity. Eur. J Biochem., v. 266, n. 3, p. 903-10, 1999.

CAZZULO, J. J. Protein and amino acid catabolism in Trypanosoma cruzi. Comp Biochem. Physiol. B., v. 79, n. 3, p. 309-20, 1984.

CAZZULO, J. J. Aerobic fermentation of glucose by trypanosomatids. Faseb J., v. 6, n. 13, p. 3153-61, 1992.

CAZZULO, J. J. Intermediate metabolism in Trypanosoma cruzi. J. Bioenerg. Biomembr., v. 26, n. 2, p. 157-65, 1994.

CAZZULO, J. J. Proteinases of Trypanosoma cruzi: patential targets for the chemotherapy of Chagas desease. Curr Top Med Chem, v.2, n.11, Nov, p.1261-71. 2002.

CAZZULO, J. J. et al. End products and enzyme levels of aerobic glucose fermentation in trypanosomatids. Mol. Biochem. Parasitol., v. 16, n. 3, p. 329-43, 1985.

CAZZULO, J. J.; STOKA, V.; TURK, V. Cruzipain, the major cysteine proteinase from the protozoan parasite Trypanosoma cruzi. Biol. Chem., v. 378, n. 1, p. 1-10, 1997.

CHAMOND, N. et al. Trypanosoma cruzi proline racemases are involved in parasite differentiation and infectivity. Mol. Microbiol., v. 58, n. 1, p. 46-60, 2005. 
CHAMOND, N., $\mathrm{C}$ et al. Biochemical characterization of proline racemases from the human protozoan parasite Trypanosoma cruzi and definition of putative protein signatures. J. Biol. Chem., v. 278, n. 18, p. 15484-94, 2003.

CHEN, C.; DICKMAN, M. B. Proline suppresses apoptosis in the fungal pathogen Colletotrichum trifolii. Proc. Natl. Acad. Sci., v. 102, n. 9, p. 3459-64, 2005.

CHEN, C. et al. Tomato QM-like protein protects Saccharomyces cerevisiae cells against oxidative stress by regulating intracellular proline levels. Appl. Environ. Microbiol., v. 72, n. 6, p. 4001-6, 2006.

CHOU, W. Y. et al. An A/G polymorphism in the promoter of mitochondrial aldehyde dehydrogenase $(\mathrm{ALDH} 2)$ : effects of the sequence variant on transcription factor binding and promoter strength. Alcohol. Clin. Exp. Res., v. 23, n. 6, p. 963-8, 1999.

CLAROS, M. G.; BRUNAK, S.; VON HEIJNE, G. Prediction of N-terminal protein sorting signals. Curr. Opin. Struct. Biol., v. 7, n. 3, p. 394-8, 1997.

COLASANTE, C. et al. Mitochondrial carrier family inventory of Trypanosoma brucei brucei: Identification, expression and subcellular localisation. Mol. Biochem. Parasitol., v. 167, n. 2 , p. $104-17,2009$.

CONTRERAS ET AL. In vitro differentiation of Trypanosoma cruzi under chemically defined conditions. Mol. Biochem. Parasitol., v. 16, n. 3, p. 315-27, 1985.

COURA, J. R. Current prospects of specific treatment of Chagas' disease. Bo.l Chil. Parasitol., v. 51, n. 3-4, p. 69-75, 1996.

COURA, J. R. Transmission of chagasic infection by oral route in the natural history of Chagas disease. Rev. Soc. Bras. Med. Trop., v. 39, n. 3, p. 113-7, 2006.

COURA, J. R. Present situation and new strategies for Chagas disease chemotherapy: a proposal. Mem. Inst. Oswaldo Cruz, v. 104, n. 4, p. 549-54, 2009.

COURA, J. R.; Dias, J. C. Epidemiology, control and surveillance of Chagas disease: 100 years after its discovery. Mem. Inst. Oswaldo Cruz, v. 104, n. 1, p.31-40, 2009.

COUSTOU, V. et al. ATP generation in the Trypanosoma brucei procyclic form: cytosolic substrate level is essential, but not oxidative phosphorylation. J. Biol. Chem., v. 278, n. 49, p. 49625-35, 2003.

COUSTOU, V., M. et al. Glucose-induced remodeling of intermediary and energy metabolism in procyclic Trypanosoma brucei. J. Biol. Chem., v. 283, n. 24, p. 16342-54, 2008.

COUTINHO, L. et al. Inhibition of Trypanosoma cruzi proline racemase affects hostparasite interactions and the outcome of in vitro infection. Mem. Inst. Oswaldo Cruz, v. 104, n. 8, p. 1055-62, 2009.

DA SILVA, A. C. R. ; REINACH, F. C.Trends Biochem. Sci., v. 16, p. 53-57, 1991. 
DAS, N. B. Studies on amino-acid dehydrogenase: Activator of proline dehydrogenase. Biochem. J., v. 30, n. 9, p.1617-21, 1936.

DE ARAUJO-JORGE, T. C. The biology of Trypanosoma cruzi-macrophage interaction. Mem. Inst. Oswaldo Cruz, v. 84, n. 4, p. 441-62, 1989.

DEMASI, A. P.; PEREIRA, G. A.; NETTO, L. E. Cytosolic thioredoxin peroxidase I is essential for the antioxidant defense of yeast with dysfunctional mitochondria. FEBS Lett., v. 509, n. 3, p. 430-4, 2001.

DE SOUSA, M. A. A simple method to purify biologically and antigenically preserved bloodstream trypomastigotes of Trypanosoma cruzi using DEAE-cellulose columns. Mem. Inst. Oswaldo Cruz, v. 78, n. 3, p. 317-33, 1983.

DE SOUZA, W. Cell biology of Trypanosoma cruzi. Int. Rev. Cytol., v. 86, p. 197-283, 1984.

DE SOUZA, W.; J. C. RODRIGUES. Sterol Biosynthesis Pathway as Target for Antitrypanosomatid Drugs. Interdiscip. Perspect. Infect. Dis., v. 2009, p. 642502, 2009.

DENTON, R. M. Regulation of mitochondrial dehydrogenases by calcium ions. Biochim. Biophys. Acta, v. 1787, n. 11, p. 1309-16, 2009.

DENTON, R. M.; RANDLE, P. J.; NETTO, L. E. Stimulation by calcium ions of pyruvate dehydrogenase phosphate phosphatase. Biochem. J., v. 128, n. 1, p. 161-3, 1972.

DIAS, J. C. Chagas disease: successes and challenges. Cad. Saude Publica, v. 22, n. 10, p. 2020-1, 2006.

DIAS, J. C. Elimination of Chagas disease transmission: perspectives. Mem. Inst. Oswaldo Cruz, v. 104, Suppl. 1, p. 41-5, 2009.

DIAS, J. P. et al. Acute Chagas disease outbreak associated with oral transmission. Rev. Soc. Bras. Med. Trop., v. 41, n. 3, p. 296-300, 2008.

DIAS, L.C et al. Quimioterapia da Doença de Chagas: Estado de Arte e Perspectivas no desenvolvimento de novos fármacos. Química Nova, v. 32, p. 2444-2457, 2009.

DIAZ DE TORANZO, E. G. et al. Interaction of benznidazole reactive metabolites with nuclear and kinetoplastic DNA, proteins and lipids from Trypanosoma cruzi. Experientia, v. 44, n. 10, p. 880-1, 1988.

DOCAMPO, R. Sensitivity of parasites to free radical damage by antiparasitic drugs. Chem. Biol. Interact., v. 73, n. 1, p. 1-27, 1990.

DOCAMPO, R.; S. N. Moreno. Acidocalcisome: A novel Ca2+ storage compartment in trypanosomatids and apicomplexan parasites. Parasitol Today, v.15, n.11, Nov, p.443-8. 1999. 
DOCAMPO, R.; MORENO, S. N. The acidocalcisome. Mol Biochem Parasitol, v.114, n.2, May, p.151-9. 2001a.

DOCAMPO, R.; MORENO, S. N. Bisphosphonates as chemotherapeutic agents against trypanosomatid and apicomplexan parasites. Curr. Drug Targets Infect. Disord., v. 1, n. 1, p.51-61, 2001b.

DOCAMPO, R., ULRICH, P.; MORENO, S. N. Evolution of acidocalcisomes and their role in polyphosphate storage and osmoregulation in eukaryotic microbes. Philos. Trans. R. Soc. Lond. B. Biol. Sci., v. 365, n. 1541, p. 775-84, 2010.

DOCAMPO, R.; VERCESI, A. E. Ca2+ transport by coupled Trypanosoma cruzi mitochondria in situ. J. Biol. Chem., v. 264, n. 1, p. 108-11, 1989.

DOYLE, P. S. et al. A cysteine protease inhibitor cures Chagas' disease in an immunodeficient-mouse model of infection. Antimicrob. Agents Chemother., v. 51, n. 11, p. 3932-9, 2007.

DUSCHAK, V. G.; CAZZULO, J. J. Subcellular localization of glutamate dehydrogenases and alanine aminotransferase in epimastigotes of Trypanosoma cruzi. FEMS Microbiol. Lett., v. 67, n. 2, p. 131-5, 1991.

DUSCHAK, V. G.; COUTO, A. S. An insight on targets and patented drugs for chemotherapy of Chagas disease. Recent. Pat. Antiinfect. Drug Discov., v. 2, n. 1, p.19$51,2007$.

EASTERBY, J. S.; O'BRIEN, M. J. Purification and properties of pig-heart hexokinase. Eur. J. Biochem., v. 38, n. 2, p. 201-11, 1973.

ELTHON, T. E.; STEWART, C. R. Proline Oxidation in Corn Mitochondria : Involvement of NAD, Relationship to Ornithine Metabolism, and Sidedness on the Inner Membrane. Plant Physiol., v. 70, n. 2, p. 567-572, 1982.

ELTHON, T. E.; STEWART, C. R. Effects of the Proline Analog 1-Thiazolidine-4carboxylic Acid on Proline Metabolism. Plant Physiol., v. 74, n. 2, p. 213-8, 1984.

ENGEL, J. C. et al. Cysteine protease inhibitors cure an experimental Trypanosoma cruzi infection. J. Exp. Med., v. 188, n. 4, p. 725-34, 1998.

ENGEL, J. C. et al. Aerobic glucose fermentation by Trypanosoma cruzi axenic culture amastigote-like forms during growth and differentiation to epimastigotes. Mol. Biochem. Parasitol., v. 26, n. 1-2, p. 1-10, 1987.

ERECINSKA, M.; CHOJNACKI, T. Participation of phospholipids in the reactions of the respiratory chain. Postepy. Biochem., v. 12, n. 4, p. 535-45, 1966.

ERMAK, G.; DAVIES, K. J. Calcium and oxidative stress: from cell signaling to cell death. Mol. Immunol., v. 38, n. 10, p. 713-21, 2002. 
ESTEVA, M. I. et al. Benzophenone-based farnesyltransferase inhibitors with high activity against Trypanosoma cruzi. J. Med.Chem., v. 48, n. 23, p. 7186-91, 2005.

EVANS, D. A.; BROWN, R. C. The utilization of glucose and proline by culture forms of Trypanosoma brucei. J. Protozool., v. 19, n. 4, p. 686-90, 1972.

FERNANDES, M. P. et al. Mechanism of Trypanosoma cruzi death induced by Cratylia mollis seed lectin. J. Bioenerg. Biomembr., v. 42, n. 1, p. 69-78, 2010.

FILARDI, L. S.; BRENER, Z. Susceptibility and natural resistance of Trypanosoma cruzi strains to drugs used clinically in Chagas disease. Trans. R. Soc. Trop. Med. Hyg., v. 81, n. 5, p. 755-9, 1987.

GARCIA, S. et al. Treatment with benznidazole during the chronic phase of experimental Chagas' disease decreases cardiac alterations. Antimicrob Agents Chemother., v. 49, n. 4, p. 1521-8, 2005.

GARFORTH, J. et al. Rational design of selective ligands for trypanothione reductase from Trypanosoma cruzi. Structural effects on the inhibition by dibenzazepines based on imipramine. J. Enzyme Inhib., v. 12, n. 3, p. 161-73, 1997.

GHISLA, S. Fluorescence and optical characteristics of reduced flavins and flavoproteins. Methods Enzymol., v. 66, p. 360-73, 1980.

GHISLA, S.; MASSEY, V. New flavins for old: artificial flavins as active site probes of flavoproteins. Biochem. J., v. 239, n. 1, p. 1-12, 1986.

GIFFORD, J. L.; WALSH, M. P.; VOGEL, H. J. Structures and metal-ion-binding properties of the Ca2+-binding helix-loop-helix EF-hand motifs. Biochem. J., v. 405, n. 2, p. 199-221, 2007.

GILBERT, R.; KLEIN, R. A. Carnitine stimulates ATP synthesis in Trypanosoma brucei brucei. FEBS Lett., v. 141, n. 2, p. 271-4, 1982.

GILBERT, R. J.; KLEIN, R. A. Pyruvate kinase: a carnitine-regulated site of ATP production in Trypanosoma brucei brucei. Comp. Biochem. Physiol. B., v. 78, n. 3, p. 595-9, 1984.

GOLDENBERG, S., FRAGOSO, S. P. GONZALES-PERDOMO, M. Trypanosoma cruzi topoisomerase II: a target enzyme for the chemotherapy of Chagas' disease? Cloning and characterization of its encoding gene. Biol. Res., v. 26, n. 1-2, p.77-80, 1993.

GRIFFITHS, E. J.; RUTTER, G. A. Mitochondrial calcium as a key regulator of mitochondrial ATP production in mammalian cells. Biochim. Biophys. Acta, v. 1787, n. 11, p. 1324-33, 2009.

GUERRIER, G. et al. Proline metabolism and NAD kinase activity in soybean calli during short- and long-term exposures to light and $\mathrm{NaCl}$. Biol. Plant., v. 40, n.1, p. 1-9, 1997. 
GUIDO, R. V. et al. Structure-activity relationships for a class of selective inhibitors of the major cysteine protease from Trypanosoma cruzi. J. Enzyme Inhib. Med. Chem., v. 23, n. 6, p. 964-73, 2008.

HAGEDORN, C. H.; PHANG, J. M. Transfer of reducing equivalents into mitochondria by the interconversions of proline and delta 1-pyrroline-5-carboxylate. Arch. Biochem. Biophys., v. 225, n. 1, p. 95-101, 1983.

HAGEDORN, C. H.; PHANG, J.M. Catalytic transfer of hydride ions from NADPH to oxygen by the interconversions of proline and delta 1-pyrroline-5-carboxylate. Arch. Biochem. Biophys., v. 248, n. 1, p. 166-74, 1986.

HANNAERT, V. et al. Evolution of energy metabolism and its compartmentation in Kinetoplastida. Kinetoplastid. Biol. Dis., v. 2, n. 1, p. 11, 2003.

HANAHAN, D. Studies on transformation of Escherichia coli with plasmids. J. Mol. Biol., v. 166, p. 557-804, 1983.

HANSFORD, R. G. Dehydrogenase activation by $\mathrm{Ca} 2+$ in cells and tissues. J Bioenerg Biomembr, v.23, n.6, Dec, p.823-54. 1991.

HANSFORD, R. G.; CHAPPELL, J.B. The effect of Ca2+ on the oxidation of glycerol phosphate by blowfly flight-muscle mitochondria. Biochem. Biophys. Res. Commun., v. 27, n. 6, p. 686-92, 1967.

HANSFORD, R. G.; SACKTOR, B. The control of the oxidation of proline by isolated flight muscle mitochondria. J. Biol. Chem., v. 245, n. 5, p. 991-4, 1970.

HIGGINS, DG, THOMPSON, JD, GIBSON, TJ. Using CLUSTAL for multiple sequence alignments. Methods Enzymol., v. 266, p. 383-402, 1996.

HOARE, C. A. The classification of mammalian trypanosomes. Ergeb Mikrobiol. Immunitatsforsch. Exp. Ther., v. 39, p. 43-57, 1966.

HOEK, J. B.; NJOGU, R. M. The role of glutamate transport in the regulation of the pathway of proline oxidation in rat liver mitochondria. J. Biol. Chem., v. 255, n. 18, p. 8711-8, 1980.

HOMSY, J. J. et al. Some factors inducing formation of metacyclic stages of Trypanosoma cruzi. J. Protozool., v. 36, n. 2, p. 150-3, 1989.

HOUDUSSE, A., SILVER, M. COHEN, C. A model of $\mathrm{Ca}(2+)$-free calmodulin binding to unconventional myosins reveals how calmodulin acts as a regulatory switch. Structure, v. 4, n. 12, p. 1475-90, 1996.

HU, C. A. et al. Overexpression of proline oxidase induces proline-dependent and mitochondria-mediated apoptosis. Mol. Cell Biochem., v. 295, n.1-2, p. 85-92, 2007. 
IGOILLO-ESTEVE, M. et al. The pentose phosphate pathway in Trypanosoma cruzi: a potential target for the chemotherapy of Chagas disease. An. Acad. Bras. Cienc., v. 79, n. 4, p. 649-63, 2007.

IRIGOIN, F., L. et al. Insights into the redox biology of Trypanosoma cruzi: Trypanothione metabolism and oxidant detoxification. Free Radic. Biol. Med., v. 45, n. 6, p. 733-42, 2008.

IRIGOIN, F. et al. Mitochondrial calcium overload triggers complement-dependent superoxide-mediated programmed cell death in Trypanosoma cruzi. Biochem. J., v. 418, n. 3, p. 595-604, 2009.

JOHN, M. W. The Proteomics Protocols Handbook. USA: Humana Press. 2005 .

KAUL, S.; SHARMA, S. S.; MEHTA, I. K. Free radical scavenging potential of Lproline: evidence from in vitro assays. Amino Acids, v. 34, n. 2, p. 315-20, 2008.

KAWASAKI, H.; KRETSINGER, R. H. Calcium-binding proteins, 1: EF-hands. Protein Profile, v. 1, n. 4, p. 343-517, 1994.

KHABNADIDEH, S. et al. Design, synthesis and evaluation of 2,4-diaminoquinazolines as inhibitors of trypanosomal and leishmanial dihydrofolate reductase. Bioorg. Med. Chem., v. 13, n. 7, p. 2637-49, 2005.

HOFMANN K.; STOFFEL, W. TMbase - A database of membrane spanning proteins segments Biol. Chem., v. 374, p. 166, 1993.

KLEIN, R. A.; ANGUS,J.M.; WATERHOUSE, A. E. Carnitine in Trypanosoma brucei brucei. Mol. Biochem. Parasitol., v. 6, n. 2, p. 93-110, 1982.

KOHL, D. H. et al. Activities of the Pentose Phosphate Pathway and Enzymes of Proline Metabolism in Legume Root Nodules. Plant Physiol., v. 94, n. 3, p. 1258-1264, 1990.

KRAUTH-SIEGEL, R. L.; COMINI, M. A. Redox control in trypanosomatids, parasitic protozoa with trypanothione-based thiol metabolism. Biochim. Biophys. Acta, v. 1780, n. 11, p. 1236-48, 2008.

KRETSINGER, R. H.; NOCKOLDS, C. E. Carp muscle calcium-binding protein. II. Structure determination and general description. J. Biol. Chem., v. 248, n. 9, p. 3313-26, 1973.

KRISHNAN, N.; BECKER, D. F. Oxygen reactivity of PutA from Helicobacter species and proline-linked oxidative stress. J. Bacteriol., v. 188, n. 4, p. 1227-35, 2006.

KRISHNAN, N.; DICKMAN,M. B.;BECKER, D. F. Proline modulates the intracellular redox environment and protects mammalian cells against oxidative stress. Free Radic. Biol. Med., v. 44, n. 4, p. 671-81, 2008. 
KYTE, J.; DOOLITTLE, R. F. A simple method for displaying the hydropathic character of a protein. J. Mol. Biol., v. 157, n. 1, p. 105-32, 1982.

LAKOWICZ, J. R. et al. Fluorescence lifetime imaging of calcium using Quin-2. Cell Calcium, v. 13, n. 3, p. 131-47, 1992.

LAMOUR, N. et al. Proline metabolism in procyclic Trypanosoma brucei is downregulated in the presence of glucose. J. Biol. Chem., v. 280, n. 12, p. 11902-10, 2005.

LAEMMLI, U.K. Clevage of structural proteins during the assembly of the head of bactheriophage T4. Nature, v. 226, p. 680-68, 1970.

LANDFEAR, S. M. Drugs and transporters in kinetoplastid protozoa. Adv. Exp. Med. Biol., v. 625, p. 22-32, 2008.

LEE, S. et al. Proteomic identification of annexins, calcium-dependent membrane binding proteins that mediate osmotic stress and abscisic acid signal transduction in Arabidopsis. Plant Cell, v. 16, n. 6, p. 1378-91, 2004.

LEE, Y. H. et al. Structure of the proline dehydrogenase domain of the multifunctional PutA flavoprotein. Nat. Struct. Biol., v. 10, n. 2, p. 109-14, 2003.

LEMIRE, B. D. et al. The mitochondrial targeting function of randomly generated peptide sequences correlates with predicted helical amphiphilicity. J Biol Chem, v.264, n.34, Dec 5, p.20206-15. 1989.

LEWIT-BENTLEY, A.; RETY, S. EF-hand calcium-binding proteins. Curr. Opin. Struct. Biol, v. 10, n. 6, p. 637-43,2000.

LIU, B. et al. Fellowship of the rings: the replication of kinetoplast DNA. Trends Parasitol., v. 21, n. 8, p. 363-9, 2005.

LIU, B. et al. Trypanosomes have six mitochondrial DNA helicases with one controlling kinetoplast maxicircle replication. Mol. Cell, v. 35, n. 4, p. 490-501, 2009.

LIU, Y. et al. MnSOD inhibits proline oxidase-induced apoptosis in colorectal cancer cells. Carcinogenesis, v. 26, n. 8, p. 1335-42, 2005.

MACDONALD, M. J.; BROWN L. J. Calcium activation of mitochondrial glycerol phosphate dehydrogenase restudied. Arch. Biochem. Biophys., v. 326, n. 1, p.79-84, 1996.

MAGDALENO, A. et al. Actions of a proline analogue, L-thiazolidine-4-carboxylic acid (T4C), on Trypanosoma cruzi. PLoS One, v. 4, n. 2, p. 4534, 2009.

MANCILLA, R.; NAQUIRA, C.; LANAS, C. Protein biosynthesis in trypanosomidae. II. The metabolic fate of DL-leucine-1-C14 in Trypanosoma cruzi. Exp. Parasitol., v. 21, $\mathrm{n}$. 2, p. 154-9, 1967. 
MANGANARO, M.; MASCELLINO, M.T.; GRADONI, L. Activity of D-carnitine and its derivatives on Trypanosoma infections in rats and mice. Parasite, v. 10, n. 2, p.147$51,2003$.

MARCIANO, D. et al. Biochemical characterization of stage-specific isoforms of aspartate aminotransferases from Trypanosoma cruzi and Trypanosoma brucei. Mol Biochem. Parasitol., v. 161, n. 1, p. 12-20, 2008.

MARCIANO, D. et al. Functional characterization of stage-specific aminotransferases from trypanosomatids. Mol. Biochem. Parasitol., v. 166, n. 2, p. 172-82, 2009.

MARSDEN, B. J., SHAW, G. S.; SYKES, B. D. Calcium binding proteins. Elucidating the contributions to calcium affinity from an analysis of species variants and peptide fragments. Biochem. Cell Biol., v. 68, n. 3, p. 587-601, 1990.

MARTINS, R. M. et al. Use of L-proline and ATP production by Trypanosoma cruzi metacyclic forms as requirements for host cell invasion. Infect. Immun., v. 77, n. 7, p. 3023-32, 2009.

MAUGERI, D. A.; CAZZULO, J. J. The pentose phosphate pathway in Trypanosoma cruzi. FEMS Microbiol. Lett., v. 234, n. 1, p. 117-23, 2004.

MAYA, J. D. et al. Mode of action of natural and synthetic drugs against Trypanosoma cruzi and their interaction with the mammalian host. Comp. Biochem. Physiol. A. Mol. Integr. Physiol., v. 146, n. 4, p. 601-20, 2007.

MAZAREB, S.; FU, Z. Y.; ZILBERSTEIN, D.. Developmental regulation of proline transport in Leishmania donovani. Exp. Parasitol., v. 91, n. 4, p. 341-8, 1999.

MCGUFFIN, L. J.; BRYSON, K.; JONES, D. T. The PSIPRED protein structure prediction server. Bioinformatics, v. 16, n. 4, p. 404-5, 2000.

MCKERROW, J. H.; ENGEL, J. C.; CAFFREY, C. R. Cysteine protease inhibitors as chemotherapy for parasitic infections. Bioorg. Med. Chem., v. 7, n. 4, p. 639-44, 1999.

MENZEL, R.; ROTH, J. Purification of the putA gene product. A bifunctional membrane-bound protein from Salmonella typhimurium responsible for the two-step oxidation of proline to glutamate. J. Biol. Chem., v. 256, n. 18, p. 9755-61, 1981.

MILLER, G. et al. Unraveling delta1-pyrroline-5-carboxylate-proline cycle in plants by uncoupled expression of proline oxidation enzymes. J. Biol. Chem., v. 284, n. 39, p. 26482-92, 2009.

MIRANDA, M. R. et al. Trypanosoma cruzi: Oxidative stress induces arginine kinase expression. Exp. Parasitol., v. 114, n. 4, p. 341-4, 2006.

MOLINARI, B. L. et al. Cell-based quantitative evaluation of the MTT assay. Anal. Quant. Cytol. Histol., v. 25, n. 5, p. 254-62, 2003. 
MONAGHAN, P. J.; LEYS, D.; SCRUTTON, N. S. Mechanistic aspects and redox properties of hyperthermophilic L-proline dehydrogenase from Pyrococcus furiosus related to dimethylglycine dehydrogenase/oxidase. FEBS J., v. 274, n. 8, p. 2070-87, 2007.

MONCAYO, A. Progress towards interruption of transmission of Chagas disease. $\underline{\text { Mem. }}$ Inst. Oswaldo Cruz, v. 94, n. 1, p. 401-4, 1999.

MONCAYO, A.; ORTIZ YANINE, M. I. An update on Chagas disease (human American trypanosomiasis). Ann. Trop. Med. Parasitol., v. 100, n. 8, p. 663-77, 2006.

MONTEMARTINI, $M$. et al. A recombinant tyrosine aminotransferase from Trypanosoma cruzi has both tyrosine aminotransferase and alanine aminotransferase activities. FEMS Microbiol. Lett., v. 133, n. 1-2, p. 17-20, 1995.

MORENO, S. N.; DOCAMPO, R. Calcium regulation in protozoan parasites. Curr. Opin. Microbiol., v. 6, n. 4, p. 359-64, 2003.

MORENO, S. N.; DOCAMPO, R. The role of acidocalcisomes in parasitic protists. J. Eukaryot. Microbiol., v. 56, n. 3, p. 208-13, 2009.

MORITA,Y.; NAKAMORI, S.; TAKAGI, H. Effect of proline and arginine metabolism on freezing stress of Saccharomyces cerevisiae. J. Biosci. Bioeng., v. 94, n. 5, p. 390-4, 2002 .

NAKAJIMA-SHIMADA, J.; HIROTA, Y.; AOKI, T. Inhibition of Trypanosoma cruzi growth in mammalian cells by purine and pyrimidine analogs. Antimicrob. Agents Chemother., v. 40, n. 11, p. 2455-8,1996.

NARA, T. et al. Inhibitory action of marine algae extracts on the Trypanosoma cruzi dihydroorotate dehydrogenase activity and on the protozoan growth in mammalian cells. Parasitol. Int., v. 54, n. 1, p. 59-64, 2005.

NERES, J. et al. Discovery of novel inhibitors of Trypanosoma cruzi trans-sialidase from in silico screening. Bioorg. Med. Chem. Lett., v. 19, n. 3, p. 589-96, 2009.

NERES, J., R.; BRYCE, A.; DOUGLAS, K. T. Rational drug design in parasitology: trans-sialidase as a case study for Chagas disease. Drug Discov. Today, v. 13, n. 3-4, p. 110-7, 2008.

NEUPERT, W. Protein import into mitochondria. Annu. Rev. Biochem., v. 66, p. 863917, 1997.

NOMURA, M.; TAKAGI, H. Role of the yeast acetyltransferase Mpr1 in oxidative stress: regulation of oxygen reactive species caused by a toxic proline catabolism intermediate. Proc. Natl. Acad. Sci., v. 101, n. 34, p. 12616-21, 2004.

NOWICKI, C.; CAZZULO, J. J. Aromatic amino acid catabolism in trypanosomatids. Comp. Biochem. Physiol. A. Mol. Integr. Physiol., v. 151, n. 3, p. 381-90, 2008. 
NOWICKI, C. et al. Presence and subcellular localization of tyrosine aminotransferase and p-hydroxyphenyllactate dehydrogenase in epimastigotes of Trypanosoma cruzi. FEMS Microbiol. Lett., v. 71, n. 2, p.119-24, 1992.

NOZAKI, T. et al. Characterization of transsulfuration and cysteine biosynthetic pathways in the protozoan hemoflagellate, Trypanosoma cruzi. Isolation and molecular characterization of cystathionine beta-synthase and serine acetyltransferase from Trypanosoma. J. Biol. Chem., v. 276, n. 9, p. 6516-23, 2001.

OPPERDOES, F. R.; BORST, P. Localization of nine glycolytic enzymes in a microbody-like organelle in Trypanosoma brucei: the glycosome. FEBS Lett., v. 80, n. 2, p. 360-4, 1977.

OSTRANDER, E. L. et al. A conserved active site tyrosine residue of proline dehydrogenase helps enforce the preference for proline over hydroxyproline as the substrate. Biochemistry, v. 48, n. 5, p. 951-9, 2009.

PEDROSA, R. C. et al. Time-dependent oxidative stress caused by benznidazole. $\underline{\text { Redox }}$ Rep., v. 6, n. 4, p. 265-70, 2001.

PELUFFO, G. et al. L-arginine metabolism during interaction of Trypanosoma cruzi with host cells. Trends Parasitol., v. 20, n. 8, p. 363-9, 2004.

PEREIRA-CHIOCCOLA, V. L.; SCHENKMAN, S. Biological role of Trypanosoma cruzi trans-sialidase. Biochem. Soc. Trans., v. 27, n. 4, p. 516-8, 1999.

PEREIRA, C. A. et al. Arginine metabolism in Trypanosoma cruzi is coupled to parasite stage and replication. FEBS Lett., v. 526, n. 1-3, p. 111-4, 2002.

PEREIRA, C. A. et al. Arginine kinase overexpression improves Trypanosoma cruzi survival capability. FEBS Lett., v. 554, n. 1-2, p. 201-5, 2003.

PEREIRA, C. A. et al. L-arginine uptake and L-phosphoarginine synthesis in Trypanosoma cruzi. J. Eukaryot. Microbiol., v. 46, n. 6, p. 566-70, 1999.

PETERSON, B. Z. et al. Critical determinants of $\mathrm{Ca}(2+)$-dependent inactivation within an EF-hand motif of L-type $\mathrm{Ca}(2+)$ channels. Biophys. J., v.78, n. 4, p. 1906-20, 2000.

PFAFFL, M. W. A new mathematical model for relative quantification in real-time RTPCR. Nucleic. Acids. Res., v. 29, n. 9, p. 45, 2001.

PHANG, J. M. The regulatory functions of proline and pyrroline-5-carboxylic acid. Curr. Top. Cell Regul., v. 25, p. 91-132, 1985.

PHANG, J. M.; DONALD,S. P.; LIU, Y. The metabolism of proline, a stress substrate, modulates carcinogenic pathways. Amino Acids, v. 35, n. 4, p. 681-90, 2008.

PHANG, J. M., DOWNING, S. J.; YEH, G. C. Linkage of the HMP pathway to ATP generation by the proline cycle. Biochem. Biophys. Res. Commun, v. 93, n. 2, p. 462-70, 1980. 
PHANG, J. M., PANDHARE, J., LIU, Y. The metabolism of proline as microenvironmental stress substrate. J. Nutr., v. 138, n.1 0, p. 2008S-2015S, 2008.

PHANG, J. M.; YEH, G. C.; HAGEDORN, C. H. The intercellular proline cycle. Life Sci., v. 28, n. 1, p.5 3-8, 1981.

PINTO, A. P. et al. Structural characterization of a recombinant flagellar calcium-binding protein from Trypanosoma cruzi. Biochim Biophys. Acta, v. 1652, n. 2, p.107-14, 2003.

PINTO DIAS, J. C. Chagas cardiomyopathy: a myth and a challenge. Arch. Inst. Cardiol. Mex., v. 60, n. 2, p.119-20, 1990.

PINTO DIAS, J. C. The treatment of Chagas disease (South American trypanosomiasis). Ann. Intern. Med., v. 144, n. 10, p. 772-4, 2006.

POLI, P. et al. Cytotoxic and genotoxic effects of megazol, an anti-Chagas' disease drug, assessed by different short-term tests. Biochem. Pharmacol., v. 64, n. 11, p.1617-27, 2002 .

PONCHEL, F. et al. Real-time PCR based on SYBR-Green I fluorescence: an alternative to the TaqMan assay for a relative quantification of gene rearrangements, gene amplifications and micro gene deletions. B.M.C. Biotechnol., v. 3, p. 18, 2003.

PORRO, D. et al. Recombinant protein production in yeasts. Mol. Biotechnol., v. 31, n. 3, p. $245-59,2005$.

PRATA, A. Chagas' disease. Infect. Dis. Clin. North. Am., v. 8, n.1, p.61-76, 1994.

PUNUKOLLU, G., et al. Clinical aspects of the Chagas' heart disease. Int. J. Cardiol., v. 115, n. 3, p. 279-83, 2007.

RAMOS, C. R. et al. A high-copy T7 Escherichia coli expression vector for the production of recombinant proteins with a minimal N-terminal His-tagged fusion peptide. Braz. J. Med. Biol. Res., v. 37, n. 8, p. 1103-9, 2004.

RASMUSSON, A. G.; GEISLER, D. A.; MOLLER, I. M. The multiplicity of dehydrogenases in the electron transport chain of plant mitochondria. Mitochondrion, $\mathrm{v}$. 8 , n. 1, p. 47-60, 2008.

RATNER, S.; CLARKE, H. T. The action of formaldehyde upon cysteine. J. Am. Chem. Soc., p. 59: 200, 1937.

REINA-SAN-MARTIN, B. et al. A B-cell mitogen from a pathogenic trypanosome is a eukaryotic proline racemase. Nat. Med., v. 6, n. 8, p. 890-7, 2000.

REITHINGER, R. et al. Eliminating Chagas disease: challenges and a roadmap. B.M.J., v. 338, p. 1283, 2009. 
RENA, B. A.; SPLITTSTOESSER, W. E. Proline dehydrogenase and pyrroline-5 carboxylate reductase from pumpkin cotyledons. Phytochemistry, v. 14, p. 3657-661, 1975.

REVELLI, S. et al. Benznidazole, a drug employed in the treatment of Chagas' disease, down-regulates the synthesis of nitrite and cytokines by murine stimulated macrophages. Clin. Exp. Immunol., v. 118, n. 2, p. 271-7, 1999.

RIBEIRO, R. D.; T. A. RISSATO E GARCIA, T. A.; BONOMO, W. C. Mechanisms of transmission of the etiological agent of Chagas' disease. Ver. Saude Publica, v. 21, n. 1, p. 51-4, 1987.

RIVAROLA, H. W.; PAGLINI-OLIVA, P. A. Trypanosoma cruzi trypanothione reductase inhibitors: phenothiazines and related compounds modify experimental Chagas' disease evolution. Curr. Drug Targets Cardiovasc. Haematol. Disord., v. 2, n. 1, p. 43-52, 2002.

RIVIERE, L. et al. Acetate produced in the mitochondrion is the essential precursor for lipid biosynthesis in procyclic trypanosomes. Proc. Natl. Acad. Sci., v. 106, n. 31, p. 12694-9, 2009.

RODRIGUES, C. O. et al. The sterol composition of Trypanosoma cruzi changes after growth in different culture media and results in different sensitivity to digitoninpermeabilization. J. Eukaryot. Microbiol., v. 48, n. 5, p. 588-94, 2001.

ROHLOFF, P.; DOCAMPO, R. A contractile vacuole complex is involved in osmoregulation in Trypanosoma cruzi. Exp. Parasitol., v. 118, n. 1, p. 17-24, 2008.

ROHLOFF, P.; RODRIGUES,C. O.; DOCAMPO, R. Regulatory volume decrease in Trypanosoma cruzi involves amino acid efflux and changes in intracellular calcium. Mol. Biochem. Parasitol., v. 126, n. 2, p. 219-30, 2003.

ROMEIRO, N. C. et al. Synthesis, trypanocidal activity and docking studies of novel quinoxaline-N-acylhydrazones, designed as cruzain inhibitors candidates. Bioorg. Med. Chem., v. 17, n. 2, p. 641-52, 2009.

ROWLAND, E. C. et al. Inhibition of in vitro intracellular growth of Trypanosoma cruzi by dicationic compounds. J. Parasitol., v. 89, n. 5, p. 1078-80, 2003.

SAMBROOK, J.; FRITSCH, F.; MANIATIS, T. Molecular Cloning: A Laboratory Manual, 2nd edn. Cold Spring Harbor, New York: Cold Spring Harbor Laboratory Press. ISBN 0-87969-309-6, 1989

SANGER, F. et al. DNA sequencing with chain-terminating inhibitors. Proc. Natl. Acad. Sci., v. 74, n. 12, p. 5463-7, 1977.

SARKAR, D. et al. Clonal response to cold tolerance in creeping bentgrass and role of proline-associated pentose phosphate pathway. Bioresour Technol, v. 100, n. 21, p. 53329, 2009. 
SCHENKMAN, S. et al. Trypanosoma cruzi invade a mammalian epithelial cell in a polarized manner. Cell, v. 55, n. 1, p. 157-65, 1988.

SCHNEIDER, G. et al. Feature-extraction from endopeptidase cleavage sites in mitochondrial targeting peptides. Proteins, v. 30, n. 1, p. 49-60, 1998.

SCHOFIELD, C. J.; JANNIN, J.; SALVATELLA, R.The future of Chagas disease control. Trends Parasitol., v. 22, n. 12, p. 583-8, 2006.

SRERE, P. A. An eclectic view of metabolic regulation: control of citrate synthase activity. Adv. Enzyme Regul., v. 9, p. 221-33, 1970.

SIGRIST, C. J. et al. PROSITE, a protein domain database for functional characterization and annotation. Nucleic Acids Res., v. 38, p. D161-6, 2010.

SILBER, A. M. et al. Amino acid metabolic routes in Trypanosoma cruzi: possible therapeutic targets against Chagas' disease. Curr. Drug Targets Infect. Disord., v. 5, n. 1, p. 53-64, 2005.

SILBER, A. M. et al. Biochemical characterization of the glutamate transport in Trypanosoma cruzi. Int. J. Parasitol., v. 36, n. 2, p.157-63, 2006.

SILBER, A. M. et al. Glucose uptake in the mammalian stages of Trypanosoma Cruzi. Mol. Biochem. Parasitol., , 2009.

SILBER, A. M. et al. Active transport of L-proline in Trypanosoma cruzi. J. Eukaryot. Microbiol., v. 49, n. 6, p. 441-6, 2002.

SKOPELITIS, D. S. et al. Abiotic stress generates ROS that signal expression of anionic glutamate dehydrogenases to form glutamate for proline synthesis in tobacco and grapevine. Plant Cell, v. 18, n. 10, p. 2767-81, 2006.

SOUZA, D. H. et al. Trypanosoma cruzi glycosomal glyceraldehyde-3-phosphate dehydrogenase: structure, catalytic mechanism and targeted inhibitor design. FEBS Lett., v. 424, n. 3, p. 131-5, 1998.

SPITZNAGEL, D. et al. Alanine aminotransferase of Trypanosoma brucei--a key role in proline metabolism in procyclic life forms. FEBS J., v. 276, n. 23, p. 7187-99, 2009.

Stolic, I., K. Miskovic, et al. Effect of 3,4-ethylenedioxy-extension of thiophene core on the DNA/RNA binding properties and biological activity of bisbenzimidazole amidines. Bioorg Med Chem, v.17, n.6, Mar 15, p.2544-54. 2009.

STRECKER, H. J. The interconversion of glutamic acid and proline. II. The preparation and properties of delta 1-pyrroline-5-carboxylic acid. J. Biol. Chem., v. 235, p. 2045-50, 1960.

STRYNADKA, N. C.; JAMES, M. N. Crystal structures of the helix-loop-helix calciumbinding proteins. Annu. Rev. Biochem., v. 58, p. 951-98, 1989. 
SYLVESTER, D.; KRASSNER, S. M. Proline metabolism in Trypanosoma cruzi epimastigotes. Comp. Biochem. Physiol. B, v. 55, n. 3B, p. 443-7, 1976.

SZABADOS, L.; SAVOURE, A. Proline: a multifunctional amino acid. Trends Plant Sci., v. 15, n. 2, p. 89-97, 2010.

TAKAGI, H. et al. Proline accumulation by mutation or disruption of the proline oxidase gene improves resistance to freezing and desiccation stresses in Saccharomyces cerevisiae. FEMS Microbiol. Lett., v. 184, n. 1, p.103-8, 2000.

TANAKA, Y.; TANOWITZ, H.; BLOOM, B. R. Growth of Trypanosoma cruzi in a cloned macrophage cell line and in a variant defective in oxygen metabolism. Infect. Immun., v. 41, n. 3, p. 1322-31, 1983.

TANNER, J. J. Structural biology of proline catabolism. Amino Acids, v. 35, n. 4, p. 719 30, 2008.

TARLETON, R. L. Chagas disease: a role for autoimmunity? Trends Parasitol., v.19, n. 10, p. 447-51, 2003.

TEAGUE, W. M. et al. Purification and properties of pyruvate dehydrogenase phosphatase from bovine heart and kidney. Biochemistry, v. 21, n. 22, p. 5585-92, 1982.

THOMSON, J. F.; KLIPFEL, F. J. Studies on the enzymic dehydrogenation of deuterated succinate. Biochim. Biophys. Acta, v. 44, p. 72-7, 1960.

TONELLI, R. R. et al. L-proline is essential for the intracellular differentiation of Trypanosoma cruzi. Cell Microbiol., v. 6, n. 8, p. 733-41, 2004.

TOWBIN, H. et al. Electrophoretic transfer of proteins from polyacrylamide gels to nitrocellulose sheets: procedure and some applications. 1979. Biotechnology, v.24, p.1459. 1992.

TRUJILLO, M.; BUDDE, H.; GORDON, J. Trypanosoma brucei and Trypanosoma cruzi tryparedoxin peroxidases catalytically detoxify peroxynitrite via oxidation of fast reacting thiols. J. Biol. Chem., v. 279, n. 33, p. 34175-82, 2004.

TSIEN, R. Y.; POZZAN, T.; RINK, T. J. Calcium homeostasis in intact lymphocytes: cytoplasmic free calcium monitored with a new, intracellularly trapped fluorescent indicator. J. Cell Biol., v. 94, n. 2, p. 325-34, 1982.

TSUGE, H. et al. Crystal structure of a novel FAD-, FMN-, and ATP-containing Lproline dehydrogenase complex from Pyrococcus horikoshii. J. Biol. Chem., v. 280, n. 35, p. 31045-9, 2005.

TURKAN, A.; HIROMASA, Y.; ROCHE, T. E. Formation of a complex of the catalytic subunit of pyruvate dehydrogenase phosphatase isoform 1 (PDP1c) and the L2 domain forms a $\mathrm{Ca} 2+$ binding site and captures PDP1c as a monomer. Biochemistry, v. 43, n. 47, p. $15073-85,2004$. 
TURRENS, J. F. The role of succinate in the respiratory chain of Trypanosoma brucei procyclic trypomastigotes. Biochem. J., v. 259, n. 2, p. 363-8, 1989.

TURRENS, J. F. Oxidative stress and antioxidant defenses: a target for the treatment of diseases caused by parasitic protozoa. Mol. Aspects Med., v. 25, n. 1-2, p. 211-20, 2004.

TURRENS, J. F. et al. Inhibition of Trypanosoma cruzi and T. brucei NADH fumarate reductase by benznidazole and anthelmintic imidazole derivatives. Mol Biochem Parasitol., v. 82, n. 1, p. 125-9, 1996.

TYLER, K. M.; ENGMAN, D. M. The life cycle of Trypanosoma cruzi revisited. Int. J. Parasitol., v. 31, n. 5-6, p. 472-81, 2001.

UNGER, L.; DEMOSS, R. D. Action of a proline analogue, 1-thiazolidine-4-carboxylic acid, in Escherichia coli. J. Bacteriol., v. 91, n. 4, p. 1556-63, 1966.

URBINA, J. A. Intermediary metabolism of Trypanosoma cruzi. Parasitol. Today, v. 10, n. 3, p. 107-10, 1994.

URBINA, J. A. Chemotherapy of Chagas' disease: the how and the why. J. Mol. Med., v. 77, n. 3, p. 332-8, 1999.

URBINA, J. A. Specific treatment of Chagas disease: current status and new developments. Curr. Opin .Infect. Dis., v. 14, n. 6, p. 733-41, 2001.

URBINA, J. A. Chemotherapy of Chagas disease. Curr. Pharm. Des., v. 8, n. 4, p. 28795, 2002.

URBINA, J. A. Ergosterol biosynthesis and drug development for Chagas disease. Mem. Inst. Oswaldo Cruz, v. 104, p. 311-8, 2009a.

URBINA, J. A. Specific chemotherapy of Chagas disease: Relevance, current limitations and new approaches. Acta Trop., Nov 10. 2009b.

URBINA, J. A.; CRESPO, A. Regulation of energy metabolism in Trypanosoma (Schizotrypanum) cruzi epimastigotes. I. Hexokinase and phosphofructokinase. Mol. Biochem. Parasitol., v. 11, p. 225-39, 1984.

URBINA, J. A. et al. Parasitological cure of acute and chronic experimental Chagas disease using the long-acting experimental triazole TAK-187. Activity against drugresistant Trypanosoma cruzi strains. Int. J. Antimicrob. Agents, v. 21, n. 1, p. 39-48, 2003.

UYEMURA, S. A. et al. Oxidative phosphorylation, $\mathrm{Ca}(2+)$ transport, and fatty acidinduced uncoupling in malaria parasites mitochondria. J. Biol. Chem., v. 275, n. 13, p. 9709-15, 2000.

VAN HELLEMOND, J. J.; OPPERDOES, F. R.; TIELENS, A. G.Trypanosomatidae produce acetate via a mitochondrial acetate:succinate CoA transferase. Proc. Natl. Acad. Sci., v. 95, n. 6, p. 3036-41, 1998. 
VAN HELLEMOND, J. J.; OPPERDOES,F. R.; TIELENS, A. G. The extraordinary mitochondrion and unusual citric acid cycle in Trypanosoma brucei. Biochem. Soc. Trans., v. 33 (Pt 5), p. 967-71, 2005.

VAN WEELDEN, S. W. et al. New functions for parts of the Krebs cycle in procyclic Trypanosoma brucei, a cycle not operating as a cycle. J. Biol. Chem., v. 280, n. 13, p. 12451-60, 2005.

VERCESI, A. E. et al. Digitonin permeabilization does not affect mitochondrial function and allows the determination of the mitochondrial membrane potential of Trypanosoma cruzi in situ. J. Biol. Chem., v. 266, n. 22, p. 14431-4, 1991.

VERCESI, A. E., R. DOCAMPO, MORENO, S. N. Energization-dependent Ca2+ accumulation in Trypanosoma brucei bloodstream and procyclic trypomastigotes mitochondria. Mol. Biochem. Parasitol., v. 56, n. 2, p. 251-7, 1992.

WANDURAGALA, S. et al. Purification and characterization of Put $1 \mathrm{p}$ from Saccharomyces cerevisiae. Arch. Biochem. Biophys. v. 498, n. 2, p. 136-42, 2010.

WANG, S. S.; BRANDRISS, M. C. Proline utilization in Saccharomyces cerevisiae: sequence, regulation, and mitochondrial localization of the PUT1 gene product. Mol. Cell Biol., v. 7, n. 12, p. 4431-40, 1987.

WHITE, T. A. et al. Structure and kinetics of monofunctional proline dehydrogenase from Thermus thermophilus. J. Biol. Chem., v. 282, n. 19, p. 14316-27, 2007.

WILKINSON, S. R.; KELLY, J. M. Trypanocidal drugs: mechanisms, resistance and new targets. Expert Rev. Mol. Med., v. 11, p. 31, 2009.

WILKINSON, S. R. et al. The Trypanosoma cruzi enzyme TcGPXI is a glycosomal peroxidase and can be linked to trypanothione reduction by glutathione or tryparedoxin. J. Biol. Chem., v. 277, n. 19, p.17062-71, 2002.

WILKINSON, S. R. et al. Distinct mitochondrial and cytosolic enzymes mediate trypanothione-dependent peroxide metabolism in Trypanosoma cruzi. J. Biol. Chem., v. 275, n.11, p.8220-5, 2000.

WOOD, J. M. Membrane association of proline dehydrogenase in Escherichia coli is redox dependent. Proc. Natl. Acad. Sci., v. 84, n. 2, p. 373-7, 1987.

World Health Organization. Technical Report Series. Control of Chagas Disease. Genova 2002. WORLD HEALTH ORGANIZATION-WHO [Dados epidemiológicas]. Avalaible from: http://www.who.int [cited 2010 June 20.

XIONG, Z. H. et al. Selective transfer of calcium from an acidic compartment to the mitochondrion of Trypanosoma brucei. Measurements with targeted aequorins. $\underline{\text { J. Biol. }}$ Chem., v. 272, n. 49, p. 31022-8, 1997. 
YOSHIDA, N.; CAMARGO, E. P. Ureotelism and ammonotelism in trypanosomatids. J. Bacteriol., v. 136, n. 3, p.1184-6, 1978.

ZELEDON, R. Comparative physiological studies on four species of hemoflagellates in culture. II. Effect of carbohydrates and related substances and some amino compounds on the respiration. J. Parasitol., v. 46, p. 541-51, 1960.

ZHANG, M. et al. Structures of the Escherichia coli PutA proline dehydrogenase domain in complex with competitive inhibitors. Biochemistry, v. 43, n. 39, p. 12539-48. 2004.

ZILBERSTEIN, D.; GEPSTEIN, A. Regulation of L-proline transport in Leishmania donovani by extracellular pH. Mol. Biochem. Parasitol., v. 61, n. 2, p. 197-205, 1993.

ZILBERSTEIN, D.; SHAPIRA, M. The role of $\mathrm{pH}$ and temperature in the development of Leishmania parasites. Annu. Rev. Microbiol., v. 48, p. 449-70, 1994. 